TESES

\title{
CONTRIBUTOS
}

\section{PARA UMA EDUCAÇÃO PARA A CIDADANIA}

\section{Professores e Alunos}

\section{em Contexto Intercultural}

SÓNIA ALMEIDA ARAÚJO

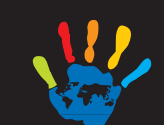

acidi 


\title{
CONTRIBUTOS PARA UMA EDUCAC̣ÃO PARA A CIDADANIA: Professores e Alunos em Contexto Intercultural
}

\author{
Sónia Almeida Araújo
}


Biblioteca Nacional de Portugal - Catalogação na Publicação

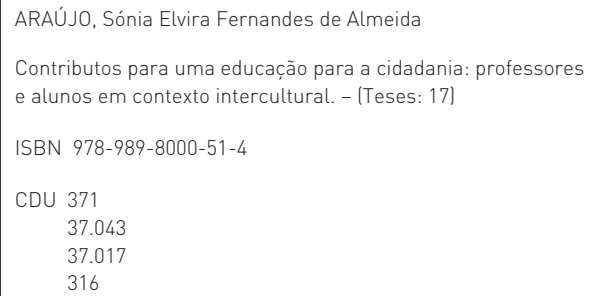

\section{PROMOTOR \\ ALTO-COMISSARIADO PARA A IMIGRAC̣̃̃O E DIÁLOGO INTERCULTURAL (ACIDI, I.P.) \\ www.acidi.gov.pt \\ AUTORA \\ SÓNIA ALMEIDA ARAÚJO \\ E-mail: sonia.araujolahotmail.com \\ EDIC̣ÃO \\ ALTO-COMISSARIADÓ PARA A IMIGRAC̣ÃO \\ E DIÁLOGO INTERCULTURAL (ACIDI, I.P.)}

RUA ÁLVARO COUTINHO, 14, 1150-025 LISBOA

TELEFONE: (00351) 218106100 FAX: (00351) 218106117

E-MAIL: acididacidi.gov.pt

EXECUC̄ÃO GRÁFICA

EDITORIAL DO MINISTÉRIO DA EDUCAÇÃO

PRIMEIRA EDIÇÃO

250 EXEMPLARES

ISBN

978-989-8000-51-4

DEPÓSITO LEGAL $280868 / 08$

LISBOA, DEZEMBRO 2008 
Dissertação de Mestrado em Relações Interculturais

Autora: Sónia Almeida Araújo

Orientadora: Professora Doutora Maria da Conceição Pereira Ramos

Universidade Aberta

2004 



\section{ÍNDICE}

PREFÁCIO

NOTA PRÉVIA

SUMÁRIO

ABSTRACT

INTRODUÇÃO 19

1. NOTAS INTRODUTÓRIAS 19

2. RELEVÂNCIA DA TEMÁTICA PARA A INVESTIGAÇÃO

3. JUSTIFICACTÃO DO INTERESSE PELA TEMÁTICÁ

4. APRESENTAÇÃO DO ESTUDO 23

5. ESTRUTURA DO TRABALHO 24

\section{PARTE I - ABORDAGEM TEÓRICA EM TORNO DAS MIGRAÇÕES,} DA COMUNICAÇ̃̃O INTERCULTURAL E DA CIDÁDANIA 27

CAPÍTULO I - DESAFIOS À SOCIEDADE E À ESCOLA

1. NOTAS INTRODUTÓRIAS 27

2. AS MIGRAÇÕES 27

2.1. Os principais factores de migração 28

2.2. Portugal: país de emigração e de imigração 31

2.3. A imigração portuguesa no contexto europeu e mundial 32

2.4. As políticas de imigração 37

2.4.1. As orientações do Conselho da Europa 41

3. A COMUNICAÇÃO E Á COMPREENSÃO INTERCULTURAL 41

4. A ESCOLA E Á DIVERSIDADE CULTURAL 48

4.1. A interculturalidade nas escolas portuguesas 51

4.2. As políticas de educação face à diversidade cultural 53

4.3. A educação intercultural 57

4.4. A educação intercultural como facilitadora da integração 60

4.5. Da educação monocultural à educação multicultural e intercultural 62

4.6. O professor intercultural 67

4.7. A educação intercultural e a educação para a cidadania 72

CAPÍTULO II - A CIDADANIA: UMA PROBLEMÁTICA DA ACTUALIDADE 75

1. NOTAS INTRODUTÓRIAS 75

2. CONCEPC̣ÕES DE CIDADANIA 
3. A CIDADANIA AO LONGO DOS TEMPOS: BREVE ANÁLISE

4. CONCEITO DE CIDADANIA: CONTRIBUTOS

PARA A SUA COMPREENSÃO

5. A CIDADANIA EM CONTEXTO ESCOLAR INTERCULTURAL 87

5.1. Que conceito de educação para a cidadania

5.2. A educação para a cidadania e a reorganização curricular

5.3. Os valores e a educação para a cidadania

5.4. O papel do professor do $1 .{ }^{\circ}$ Ciclo do Ensino Básico

\section{CAPÍTULO III - ANÁLISE DA CIDADANIA A PARTIR DE LEGISLAC̣ÃO E DOCUMENTOS ORIENTADORES}

1. NOTAS INTRODUTÓRIAS

2. O DISCURSO EXPRESSO NA CONSTITUICCÃO DA REPÚBLICA

3. A LEI DE BASES DO SISTEMA EDUCATIVO

4. A REFORMA DO SISTEMA EDUCATIVO

4.1. O programa do Primeiro Ciclo do Ensino Básico 117

4.1.1. A democracia

4.1.2. A identidade nacional

4.1.3. A coesão e diversidade social

4.1.4. A economia

4.1.5. Os problemas locais

4.2. O documento orientador das políticas para o Ensino Básico

5. A REORGANIZAÇÃO CURRICULAR DO ENSINO BÁSICO

5.1. O Currículo Nacional do Ensino Básico:

competências essenciais

6. ORIENTAC̣ÕES A NIVEL INTERNACIONAL

\section{PARTE II - CONTEXTO DA INVESTIGAC̣ÃO EMPÍRICA}

1. NOTAS INTRODUTÓRIAS

2. A ENUNCIAÇÃO DO PROBLEMA

3. A AMOSTRA

4. A ELABORACÃO DOS GUIÕES DAS ENTREVISTAS

5. A APLICAÇÃOO DAS ENTREVISTAS

5.1. Ao grupo de professores

5.2. Ao grupo de alunos

5.3. Ao grupo de encarregadas de educação

6. A ANÁLISE DE CONTEÚDO COMO MEIO

PARA A CONSTRUÇÃO DE CONHECIMENTO 
PARTE III - AS VOZES DOS ENTREVISTADOS

CAPÍTULO V - ANÁLISE E INTERPRETAÇÃO DOS RESULTADOS DA INVESTIGAÇÃO

1. NOTAS INTRODUTÓRIAS

2. ANÁLISE QUALITATIVA AO GRUPO DE PROFESSORES 161

2.1. Síntese das ideias centrais do grupo de professores 192

3. ANÁLISE QUALITATIVA AO GRUPO DE ALUNOS 198

3.1. Síntese das ideias centrais do grupo de alunos 210

4. ANÁLISE QUALITATIVA AO GRUPO DE ENCARREGADOS

DE EDUCAÇ̃̃O

4.1. Síntese das ideias centrais do grupo de encarregadas de educação

5. CRUZAMENTO DE ALGUNS DADOS OBTIDOS

NAS ENTREVISTAS 


\section{ÍNDICE DE QUADROS}

\section{Capítulo I}

Quadro I - Autorizações de permanência temporárias concedidas

- Portugal

Quadro II - Estrangeiros com estatuto legal de residência em Portugal (2001)

Quadro III - População estrangeira residente em Portugal (proveniente da Bulgária, Moldávia, Rússia e Ucrânia), por nacionalidade e sexo

Quadro IV - Políticas de imigração em Portugal

Quadro V - Situação escolar dos alunos por grupos étnicos e nível de ensino

Quadro VI - Alunos matriculados no Ensino Básico Regular - 1. ${ }^{\circ}$ ciclo Ano lectivo de 1999/2000 (Portugal - continente)

Quadro VII - Características do professor inter/multicultural

\section{Capítulo II}

Quadro VIII - Direitos conferidos ao cidadão

\section{Capítulo IV}

Quadro IX - Caracterização dos professores entrevistados

- dados relativos à docência

Quadro X - Caracterização dos professores entrevistados

- dados pessoais e académicos

Quadro XI - Caracterização dos alunos entrevistados

Quadro XII - Caracterização das encarregadas de educação entrevistadas

Quadro XIII - Relações entre os entrevistados dos três grupos em estudo

Quadro XIV - Guião da entrevista aos professores

Quadro XV - Guião da entrevista aos alunos

Quadro XVI - Guião da entrevista às encarregadas de educação

Quadro XVII - Dimensões de análise das entrevistas aos professores

Quadro XVIII - Dimensões de análise das entrevistas aos alunos

Quadro XIX - Dimensões de análise das entrevistas às encarregadas de educação

Quadro XX - Sistema categorial das entrevistas aos professores

Quadro XXI - Sistema categorial das entrevistas aos alunos

Quadro XXII - Sistema categorial das entrevistas às encarregadas de educação 


\section{SIGLAS UTILIZADAS}

ACIDI, I. P. - Alto-Comissariado para a Imigração e Diálogo Intercultural

ACIME - Alto-Comissário para a Imigração e Minorias Étnicas lesta sigla passou a designar abreviadamente o Alto-Comissariado para a Imigração e Minorias Étnicas a partir de 22/11/2002)

1. ${ }^{\circ}$ CEB - Primeiro Ciclo do Ensino Básico

LBSE - Lei de Bases do Sistema Educativo

DEB - Departamento da Educação Básica

OCDE - Organização de Cooperação e de Desenvolvimento Económicos

ONU - Organização das Nações Unidas

UNESCO - Organização das Nações Unidas para a Educação, Ciência e Cultura

MAI - Ministério da Administração Interna

ME - Ministério da Educação

INE - Instituto Nacional de Estatística

CNE - Conselho Nacional de Educação

PALOP - Países Africanos de Língua Oficial Portuguesa

PREDI - Projecto "Educação Intercultural” (do Entreculturas)

SEF - Serviço de Estrangeiros e Fronteiras

ATL - Actividades de Tempos Livres 



\section{PREFÁCIO}

Docente do ensino básico, a Mestre Sónia Almeida Araújo realizou a sua dissertação subordinada ao tema Contributos para uma educação para a cidadania: professores e alunos em contexto intercultural, no âmbito do Mestrado em Relações Interculturais da Universidade Aberta, no Porto.

A autora desenvolve na sua obra conhecimentos, práticas e vivências do meio onde exerce a sua actividade profissional, abordando as questões das migrações, da educação e comunicação intercultural e da cidadania, com incidência em crianças oriundas do Brasil e do Leste da Europa, a frequentar a escola em Portugal.

A crescente diversidade na escola e na sociedade, o direito de todas as crianças ao sucesso educativo e à igualdade de oportunidades exigem que a educação intercultural e a educação para a cidadania tenham uma importância crescente no sistema educativo. A autora procurou compreender esta problemática e responder a algumas questões: como têm as políticas educativas valorizado a educação para a cidadania? como pode a educação para a cidadania contribuir para o desenvolvimento da consciência crítica dos alunos? Entrevistou professores, alunos e encarregados de educação com o objectivo de entender o papel do professor do $1 .{ }^{\circ}$ ciclo do ensino básico na construção da cidadania e compreender a forma de integração na escola portuguesa de crianças imigrantes e as suas vivências no nosso país. Assim, procurou fornecer contributos pedagógicos no âmbito da educação para a cidadania em contexto intercultural e pistas de reflexão para os educadores/professores.

Na educação para a cidadania, é necessário desenvolver a capacidade de compreensão e intervenção no relacionamento com outras culturas e espaços, fomentar o respeito pelas diferentes identidades nacional, religiosa e étnica. Esta dimensão da educação deve constituir um caminho de aprendizagem do respeito e da aceitação da diferença, entendendo o pluralismo como uma característica e, simultaneamente, um enriquecimento da nossa sociedade.

A educação para a cidadania tem subjacentes valores democráticos de participação, solidariedade e responsabilidade, mas implica práticas pedagógicas coerentes com os valores defendidos. Deve ser alicerçada em modelos educativos que estimulem o aperfeiçoamento do comportamento humano ao nível da solidariedade e da justiça, valorizando o diálogo e o espírito de participação na vida da comunidade. 
A família e a escola surgem como os meios essenciais para a difusão dos conhecimentos cívicos pela sociedade. A educação para a cidadania aparece interligada com os métodos de educação e aprendizagem comuns a outras esferas de conhecimento. A referência à escola ou a disciplinas específicas do percurso educativo permanecem como o principal meio desta aprendizagem. Em meio escolar, o desenvolvimento das competências de cidadania faz-se, quer pela criação de uma disciplina específica e exclusivamente direccionada para o efeito, quer pela integração de conteúdos relacionados ao nível de outras disciplinas e actividades.

A educação para a cidadania deverá ter um papel preponderante no que concerne à construção de uma cidadania plena, integrada e activa, devendo fazer parte dos currículos de todas as escolas. Se a educação constitui um campo estratégico fundamental para o desenvolvimento das práticas de cidadania, todavia, a educação para a cidadania não diz exclusivamente respeito ao domínio escolar, mas também à vida social como um todo, ou seja, é um trabalho contínuo que se opera nas mais diversas áreas da sociedade, transcendendo o espaço físico da escola.

Os resultados da investigação da autora mostram que a escola e o professor têm um papel fundamental a desempenhar na educação para a cidadania, mas que esta compete a todas as instituições da sociedade, sendo importante para o enriquecimento global das crianças, como pessoas, e para o desenvolvimento global da sua personalidade. A educação intercultural articula-se com a educação para a cidadania, sendo fundamental para a manutenção da identidade cultural e facilitadora da integração. A prática da educação intercultural é identificada pelos professores inquiridos como um contributo para o sucesso escolar dos alunos com diferentes culturas.

Nesta era de globalização e de mobilidade humana, um número crescente de crianças migrantes terá múltiplas pertenças e cidadanias. A coexistência de cidadãos com dupla nacionalidade é um desafio importante e estimulante para o sistema educativo e, simultaneamente, uma oportunidade de aprendizagem e aquisição de competências sociais de gestão de diversidade cultural e social. A educação para a cidadania tem também responsabilidades específicas junto dos cidadãos com dupla nacionalidade, devendo ajudá-los a exercer uma cidadania activa. A escola deve ter um papel importante na promoção de uma cidadania inclusiva, indo ao encontro das diferentes necessidades educativas dos cidadãos, respondendo com flexibilidade e desenvolvendo a riqueza do seu capital cultural múltiplo. 
A escola constitui para a família migrante um espaço importante de contacto e de integração na sociedade de acolhimento e um instrumento de mobilidade social e de aquisição de competências interculturais. A afirmação do princípio de interculturalidade contribui para a coesão social. Constituindo a escola um importante elo de ligação à sociedade de acolhimento, devem ser criados os meios que possibilitem a adequação da instituição escolar à sua realidade multicultural. A aposta na formação dos professores, na pedagogia intercultural, na valorização das opções vocacionais da população migrante e das suas realidades linguísticas e socioculturais, na validação das aprendizagens no país de origem, são factores a considerar na inserção escolar e profissional das populações migrantes.

Em Portugal, ao nível institucional, várias medidas têm sido promovidas para fazer face à diversidade cultural e linguística, nomeadamente no sistema escolar. A legislação actual na União Europeia visa assegurar que os filhos de imigrantes tenham acesso à educação nas mesmas condições que os nacionais de qualquer país membro da União. Também no que respeita à educação das crianças migrantes, o Conselho da Europa recomenda aos Estados dos países de imigração que facilitem o ensino da língua nacional e avancem no sentido de lhes permitir a aprendizagem da sua língua materna.

A União Europeia decidiu assinalar o ano de 2008, como o Ano Europeu do Diálogo Intercultural, pretendendo-se que este diálogo valorize a diversidade, mantendo a coesão social. O desenvolvimento das competências interculturais é indispensável para a cultura democrática e a coesão social. Estas competências constituem um elemento da cidadania e da educação para os direitos do homem. As políticas educativas devem introduzir as competências chave para a comunicação intercultural nos programas de todos os níveis de ensino, considerando o diálogo intercultural como um objectivo principal da educação. No seio do currículo formal, as exigências interculturais atravessam todas as matérias.

O Conselho da Europa tem proposto o desenvolvimento de instrumentos para melhorar e reforçar o diálogo intercultural e a coesão social, preconizando a introdução de políticas, de estratégias e de métodos de ensino de história com múltiplas perspectivas, a diversidade cultural, o respeito mútuo e a tolerância. As autoridades públicas e todos os actores sociais devem desenvolver o potencial do diálogo intercultural nos espaços físicos da vida quotidiana, nomeadamente nas escolas. Há que garantir que os direitos, o bem-estar e as necessidades educativas das crianças migrantes sejam integralmente respeitados por todos os membros da sociedade. 
A presente investigação aborda uma problemática de grande actualidade e pertinência para aqueles que se interessam pelas políticas educativas e pelo papel da educação na edificação da cidadania.

Professora Doutora Maria da Conceição Pereira Ramos Universidade do Porto - Faculdade de Economia Centro de Estudos das Migrações e das Relações Interculturais (CEMRI) - Universidade Aberta Abril de 2008 


\section{NOTA PRÉVIA}

Contributos para uma Educação para a Cidadania: Professores e Alunos em Contexto Intercultural é o produto de um trabalho de investigação inserido no Mestrado em Relações Interculturais da Universidade Aberta, orientado pela Professora Doutora Maria da Conceição Pereira Ramos. Consiste numa dissertação, defendida em Março de 2005, que estuda a relação da escola com a cidadania. 0 estudo procura ainda definir e identificar o papel do professor do $1 .{ }^{\circ}$ Ciclo do Ensino Básico na construção da cidadania em contexto intercultural e compreender de que forma foi realizada a integração de crianças imigrantes na escola portuguesa.

Dado que a temática, o quadro conceptual, as opções metodológicas e os resultados obtidos neste trabalho de investigação continuam actuais, justifica-se, deste modo, a pertinência desta publicação que constitui uma oportunidade de divulgar o estudo realizado. No entanto, tendo em consideração que houve alguma evolução no quadro legislativo, efectuei uma actualização do mesmo.

Sem a cooperação, o estímulo e o apoio de variadas pessoas o desenvolvimento do trabalho não teria sido possível, pelo que pretendo expressar os meus agradecimentos a todos os que contribuíram para a sua concretização. Agradeço à Professora Doutora Maria da Conceição Ramos o seu estímulo e a sua dedicação na orientação: a disponibilidade, a leitura atenta e crítica, os momentos de partilha e os contributos válidos e relevantes que possibilitaram a elaboração desta investigação. Agradeço ainda, de uma forma especial, a todos quantos se disponibilizaram para colaborar no estudo, dando o seu contributo através da partilha das suas opiniões e perspectivas, tornando possível a produção deste trabalho. A todos os colegas que se interessaram e me ajudaram, contribuindo igualmente para a realização deste projecto. Aos meus pais, Beatriz e David, e à minha irmã Sofia que me apoiaram com o afecto, o carinho e a atenção tão particulares e que me estimularam no prosseguimento deste trabalho. Ao meu marido, Jorge, pelo seu apoio e incentivo constantes, e aos meus filhos Tiago e Gonçalo, aos quais dedico esta dissertação. Com ela espero ter-lhes transmitido um exemplo de perseverança e de investimento a nível pessoal e académico. 


\section{SUMÁRIO}

A realidade de Portugal como país de imigração coloca a sociedade perante a presença de indivíduos de diversas nacionalidades, contribuindo uma multiplicidade rica de culturas, onde a comunicação intercultural é uma necessidade e essencial para a coexistência e compreensão entre todas as pessoas. Neste contexto, a escola encontra-se confrontada com novos desafios impostos por uma população escolar cada vez mais diferenciada a nível cultural.

A escola como local de convivência de diferentes culturas e de potenciais conflitos tem como tarefa e desafio a educação integral das crianças como pessoas, devendo ter em atenção, na sua acção, a diversidade cultural dos alunos que deve ser considerada um factor de coesão e de enriquecimento pessoal e social. A educação tem o papel de ajudar a compreender o mundo e o outro, bem como o de cultivar o sentido de solidariedade, autonomia e responsabilidade, para que cada um se compreenda melhor a si mesmo. A educação deve igualmente assumir a aspiração de proporcionar a todos os alunos os meios indispensáveis a uma cidadania democrática, consciente e activa.

Deste modo, debruçamo-nos neste trabalho sobre a temática da escola e da sua relação com a cidadania, considerando que a escola face à cidadania é um incontornável problema contemporâneo. O objectivo deste trabalho consiste em definir e identificar qual o papel do professor do 1. ${ }^{\circ}$ Ciclo do Ensino Básico na construção da cidadania em contexto intercultural. Pretendemos ainda compreender de que forma foi realizada a integração na escola portuguesa de crianças imigrantes e conhecer as suas opiniões, mas também as das suas encarregadas de educação sobre as vivências no nosso país.

Após uma revisão da literatura, na primeira parte do estudo são exploradas questões teóricas relativas às migrações, à comunicação e educação intercultural e à cidadania, tanto a nível da evolução do seu conceito, como ao seu enquadramento legislativo e da sua importância em contexto escolar intercultural.

Na segunda parte, realizamos um trabalho empírico que envolveu três grupos de pessoas: dez docentes, dez alunos (cinco com nacionalidade brasileira e cinco provenientes de países do leste europeul e sete encarregadas de educação. A análise do material empírico recolhido possibilitou uma melhor compreensão da temática e a obtenção de respostas às nossas questões de investigação formuladas. 
Com este trabalho pretendemos contribuir para a prática de uma educação para a cidadania imbuída de valores democráticos e pluralistas. Cabe à escola e aos professores, na sua missão de educar, cumprir a tarefa de cooperar no sentido da formação integral da pessoa, combinando o saber com a liberdade e o incentivo à participação, isto é, trabalhar no sentido de formar cidadãos informados, solidários, conscientes, exigentes e intervenientes, no âmbito de uma cidadania efectiva. 


\begin{abstract}
The Portuguese reality as an immigrating country places society before the presence of individuals from many nationalities, contributing for the formation of a cultural mosaic, rich in multiple cultures. Within this context, the school faces new challenges imposed by a school body more and more differentiated culturally wise. The school as a bonding place of different cultures and of potential conflicts has the task and the challenge of an overall integration of the children as people, keeping in mind, in its action, the cultural diversity of the students, which should be considered a cohesion factor and social and personal enrichment. Education has the role of cultivating the sense of solidarity, autonomy and responsibility, so that each one has a better knowledge of himself, the world and the others. Education must also assume the aspiration of providing to every student the indispensable means to a democratic citizenship, conscientious and active.
\end{abstract}

This way, we lean over this theme of school and citizenship, considering the contemporary problem of school facing citizenship. The aim of this work is to identify the role of the $1 .^{\circ}$ Ciclo of Ensino Básico lelementaryl teacher in the building of citizenship in an intercultural context. We aspire to comprehend which way the immigrants' children integration in a Portuguese school was done and, get to know their opinions, as well as the opinions of parents or other responsible adults about their living in our country.

After revising the literature, in the first part of the study theoretical questions are explored relative to migration, to communication and intercultural education and citizenship, as much as the level of evolution of its concept, as well as it's legislative framing and its importance within the school context, essential to this work. On the second part we realize an empiric work that involved three groups of people: ten teachers, ten students (five Brazilians and five from east European countries) and seven responsible adults for these students. The analysis of the gathered empiric material made possible a better comprehension of the theme and the acquisition of answers to the formulated investigation questions.

With this work we may contribute to the practice of an education towards citizenship, in a way of the emerging pluralism, which tends to a fair, democratic, solicit and free picture. It's up to the school and the teachers, in its educational mission to fulfil the task of cooperation in a sense of integral upbringing of the individual, working in the sense of raising informed citizens, solicit, conscious, exigent and intervenient, in the range of an effective citizenship. 


\section{INTRODUÇÃO}

\section{NOTAS INTRODUTÓRIAS}

Actualmente vivemos num mundo complexo, plural e em mudança. Devido à globalização, às migrações internacionais e nacionais, aos conflitos internacionais e à construção da Europa Social e de uma cidadania europeia temos de aprender a conviver e a comunicar numa sociedade multicultural em que a diversidade cultural, social, étnica e linguística é uma realidade e um enriquecimento. A Europa é, nos nossos dias, uma realidade multicultural e os movimentos migratórios continuam a fazer convergir para o espaço europeu populações com origem diversificadas a nível étnico e cultural. Estamos perante não apenas de diversidades individuais, mas também de diversidades sistémicas, emergentes das sociedades pluralistas. Constatamos que Portugal tem cada vez mais representações dessas populações de diferentes nacionalidades, línguas e tradições, devido ao nosso passado histórico e também devido aos mais recentes fenómenos migratórios.

O sistema educativo e particularmente a instituição escolar não podem ignorar esta realidade actual, pois têm um papel decisivo a desempenhar nos processos de integração e de construção de uma cidadania para todos, como resposta à diversidade cultural e étnica dos alunos que a frequentam. As questões relacionadas com a multiculturalidade, com a comunicação e o confronto entre as diversas culturas, com os problemas da imigração, colocam algumas questões à política educativa, particularmente, questionam o conceito, tão debatido hoje em dia, que é a Educação para a Cidadania e a sua importância na educação das nossas crianças e jovens. A educação escolar é um processo que contribui para o desenvolvimento integral da pessoa e para a construção da sua identidade, como cidadão responsável e participante no desenvolvimento humano da sociedade, na democracia participativa e na solidariedade. Nesta perspectiva, a cidadania não se ensina apenas como estatuto que se transmite e reproduz, não é somente um estatuto, mas sim um processo de construção pessoal e colectivo, com base na actividade da educação ao longo da vida.

Neste contexto, a compreensão e análise das mudanças ocorridas numa sociedade multicultural em contexto de globalização são necessárias para a construção de processos, em variados domínios, promotores da igualdade de oportunidades. No que diz respeito à igualdade de oportunidades e de sucesso educativo, espera-se que a escola e os seus professores, na sua tarefa de educar para uma cidadania democrática, estejam 
atentos às complexidades dos movimentos demográficos, às suas realidades sociais e às relações entre culturas e pessoas. É necessário ter em conta as situações de desigualdade e de injustiça sociais e tentar efectivar o direito à igualdade de tratamento e à afirmação das diferenças.

A reflexão sobre a diversidade cultural e a descentração dos valores da sua própria cultura para conseguir olhar a sociedade na perspectiva das minorias, são atitudes do professor, indispensáveis para organizar e estruturar as actividades escolares no sentido de promover uma igualdade de oportunidades. Para isso é necessário conhecer e valorizar as características das culturas das minorias e ter em atenção que os alunos, quando entram na escola, já são portadores dos fundamentos de uma identidade cultural, adquiridos durante a socialização primária, na família e na comunidade de origem.

Em todo este processo, o papel do professor na promoção da igualdade de oportunidades educativas e na construção de uma cidadania democrática é determinante. Para actuar numa sociedade democrática e intercultural deve o professor possuir as características necessárias à realização de uma educação pluralista e intercultural. No entanto, devido à tradicional inadequação da organização da escola face à diversidade e a certas especificações da cultura dos professores ainda se considera que idealmente o grupo-classe «normal» deve ser definido em função das características da cultura portuguesa, obedecendo a um perfil de criança falante da língua portuguesa, católico, da classe média. Neste contexto, a diversidade é vista como um obstáculo à tarefa de ensinar, no entanto, esta tendência dos professores para a percepção dos alunos mais enquanto grupo do que individualidade, tem profundas raízes institucionais e profissionais. A crescente diversidade na nossa sociedade e nas nossas escolas e o direito de todas as crianças ao sucesso educativo e à igualdade de oportunidades na escola e na sociedade exigem que a educação intercultural e a educação para a cidadania tenham uma importância crescente no sistema educativo. Elas deverão estar presentes em cada momento das actividades das escolas, garantindo a todas as crianças uma aprendizagem de identidade e de responsabilidade numa sociedade cada vez mais aberta e multifacetada.

\section{RELEVÂNCIA DA TEMÁTICA PARA A INVESTIGAC̣ÃO}

A cidadania, nas suas distintas dimensões de direitos, deveres e responsabilidades, transformou-se actualmente num desafio importante e estimulante para o sistema educativo de países democráticos e pluralistas. 
Educar é uma tarefa de enorme exigência nos nossos dias e a instituição escolar reflecte as crises, antinomias e os riscos que ameaçam as sociedades modernas, colocando em causa o sentido de solidariedade, de responsabilidade social e de comunidade, pois não podemos conceber a escola fora do contexto da sociedade em geral e, também, da especificidade das culturas dos espaços em que se situa. Como salienta Jorge Sampaio (in Henriques et al., 1999: 4), «a cidadania é a responsabilidade perante nós e perante os outros, consciência de deveres e de direitos, impulso para a solidariedade e para a participação, é sentido de comunidade e de partilha, é insatisfação perante o que é injusto ou está mal, é vontade de aperfeiçoar, de servir, de realizar, é espírito de inovação, de audácia, de risco, é pensamento que age a acção que se pensa». É através da educação, entendida como um processo de socialização, que tomamos consciência que somos cidadãos pertencentes a uma sociedade democrática que constitui um Estado-Nação, a uma Europa cujo projecto social, cultural, político e económico pressupõe a existência de uma cidadania europeia, e reconhecemo-nos como cidadãos do mundo preocupados e mobilizados para as questões ambientais, para os direitos humanos, para o direito à diferença, para a igualdade entre mulheres e homens, para o respeito pela diversidade cultural, para a tolerância activa e para o combate contra todas as formas de exclusão e de discriminação.

\section{JUSTIFICAC̣ÃO DO INTERESSE PELA TEMÁTICA ${ }^{1}$}

As motivações que conduziram à elaboração deste trabalho de investigação prendem-se com o meu percurso pessoal, social e profissional, onde têm grande relevância os meus saberes adquiridos ao longo da vida, os meus valores e as opções tomadas na construção da minha identidade profissional e pessoal. Ao empreender este trabalho, e como docente do $1 .{ }^{\circ} \mathrm{CEB}$, considero essencial promover o meu auto-conhecimento e sinto ser necessário repensar a educação e as suas implicações no nosso mundo em acelerada mudança. Subjacente a este trabalho está um percurso de dezasseis anos de docência no $1 .{ }^{\circ}$ CEB, no qual me envolvi intensamente e obtive diversas e importantes experiências pedagógicas e pessoais, mas onde também surgiram alguns dilemas que provocaram questionamentos e reflexões. A minha implicação e dedicação a este trabalho avivaram memórias de momentos vividos em contexto profissional, dos contributos teóricos provenientes da formação inicial no Magistério

1. Para justificar o interesse pela temática, considerámos mais adequado utilizar a primeira pessoa do singular, uma vez que se trata de expor motivações pessoais, profissionais e académicas. 
Primário do Porto, das diversas formações contínuas realizadas, da licenciatura em Ciências da Educação na Faculdade de Psicologia e Ciências da Educação da Universidade do Porto, da qual destaco o estágio de $4 .^{\circ}$ ano que contribuiu para um crescimento pessoal e profissional, tendo sido um espaço de reflexão, investigação e acção. Saliento, ainda, a frequência das disciplinas da parte curricular do Mestrado em Relações Interculturais da Universidade Aberta se tornaram determinantes na elaboração deste trabalho.

Foi este percurso e a vontade de compreender e de aprofundar certas questões educativas e modos de ser profissional no campo educativo que me conduziu a trabalhar a temática das relações interculturais, relacionando-a com a questão da cidadania em contexto educativo.

Assim, tenciono deixar algumas contribuições pedagógicas no âmbito da educação para a cidadania em contexto intercultural e pistas de reflexão para o cidadão com responsabilidade profissional acrescida por ser um educador, professor, formador de futuros cidadãos.

Como sabemos, a diversidade cultural presente na instituição escolar deve ser compreendida e avaliada num quadro de respeito mútuo. Trata-se de praticar uma autonomia cultural, um modo partilhado de resolver conflitos e de se pensar sobre problemas comuns no sentido de uma verdadeira convivência intercultural, e não apenas ensinar a manter e a respeitar identidades culturais diferentes.

Deste modo, compete à educação acolher as culturas distintas, sem destruir as suas especificidades próprias, e a escola tem de ensinar a viver a diferença, seja ela de teor cultural, étnico ou sexual, compreendendo que a diversidade cultural significa diferentes formas de conhecer, privilegiando-se, assim, o contacto e o diálogo entre diversos modos de sentir, de pensar e de agir. Essa intenção implica uma filosofia da educação que não ignore nem deprecie a cultura das minorias presentes na escola, frequentemente apreciada apenas nos domínios da dança, da música ou dos costumes sociais, mas que considere claramente as estruturas epistemológicas e as indicações de cariz ideológico próprias.

Nas sociedades actuais, a educação para a cidadania deve basear-se distintamente numa atitude intercultural que não só viabiliza a motivação para participar, mas também incita ao conhecimento, à aquisição e interiorização de valores que permitem o desenvolvimento harmonioso da criança que será o futuro cidadão. Somente aceitando as diferenças e semelhanças das pessoas, os seus valores culturais e sociais, estimu- 
lando o diálogo, a comunicação e a compreensão intercultural é que a escola poderá perceber o verdadeiro potencial da diversidade e extinguir o preconceito. Uma vez que a diversidade cultural surge como uma das características principais do nosso mundo contemporâneo, a escola torna-se no espaço onde se aprende a viver a diferença que será o incentivo para as grandes questões éticas do nosso século.

\section{APRESENTAĈ̣̃O DO ESTUDO}

Delimitámos o objecto de análise à escola do $1 .{ }^{\circ} \mathrm{CEB}$, na sua vertente pedagógica, do modo como ela se expressa no discurso dos professores, pois consideramos que os seus professores têm um papel muito importante no desenvolvimento e na formação integral dos seus alunos e também na promoção de igualdades educativas assegurando a todas as crianças as aprendizagens de que depende largamente o sucesso nos percursos escolares ulteriores. Esperamos poder contribuir para uma melhor compreensão da escola e do professor do $1 .{ }^{\circ}$ CEB enquanto profissional, cuja visão interior é de difícil acesso aos olhares exteriores, através da metodologia adoptada por nós neste trabalho de dar voz aos professores. Não se trata de estudar a dinâmica interna das relações profissionais, mas as opiniões dos professores sobre o seu papel na construção da cidadania em contexto intercultural. Para isso, apoiamo-nos em entrevistas semi-directivas de vinte professores do $1 .{ }^{\circ}$ CEB a leccionar turmas heterogéneas a nível cultural e a nível de nacionalidades dos seus alunos. No âmbito deste trabalho de investigação, pretendemos dar voz aos professores através dos seus discursos expressos nas entrevistas. Consideramos que é necessário escutar as pessoas mais directamente envolvidas com a temática deste trabalho e com a prática docente, ou seja, os professores. Deste modo e secundando Ivor Goodson (1995: 69) tentámos estabelecer estratégias que permitissem «facilitar, maximizar e, em sentido real, surpreender a voz dos professores». Assim, e para obter as respostas às nossas questões de investigação, a escolha recaiu sobre professores com alunos brasileiros e de países de leste, os quais foram entrevistados, pois no âmbito deste trabalho abordamos igualmente a questão das migrações e a integração das crianças imigrantes nas escolas portuguesas. Entrevistámos ainda as suas encarregadas de educação, pois consideramos que as suas opiniões poderiam ser uma mais-valia para este trabalho.

Apresentam-se agora as fases de execução e de desenvolvimento do trabalho de investigação, tendo como base um plano geral do estudo, cuja sequência enunciamos para facilitar a leitura: análise de textos relevan- 
tes para a problemática em estudo e análise documental de legislação e de outros documentos orientadores do Ministério da Educação; enunciação do problema; revisão da literatura; formulação das questões de investigação; definição da população-alvo e escolha da técnica de recolha de dados; determinação da amostra; desenvolvimento do instrumento de recolha de dados - entrevistas semi-directivas; aplicacão das entrevistas semi-directivas a três grupos distintos de pessoas: professores, alunos e encarregadas de educação; recolha dos dados, tratamento, análise e interpretação dos resultados obtidos; preparação e organização do relatório de estudo e redacção das conclusões. ${ }^{2}$

\section{ESTRUTURA DO TRABALHO}

Este trabalho encontra-se organizado em três grandes partes que se interligam e se enriquecem mutuamente.

A Parte I, intitulada Abordagem teórica em torno das migrações, da comunicação intercultural e da cidadania, tem como objectivo principal a construção de um quadro teórico para fundamentar de forma consistente o trabalho empírico e encontra-se dividida em três capítulos;

- no capítulo / - Desafios à sociedade e à escola actual - destaca- se a especificidade da situação do nosso país como país de emigração/imigração, abordando a questão da imigração na actualidade e as suas implicações na sociedade portuguesa. Salienta-se a importância da comunicação e da compreensão intercultural na sociedade actual pluralista. Analisamos de que modo essa diversidade cultural se manifesta nas escolas, qual a posição das políticas educativas face a esta realidade, a relevância da prática de uma educação intercultural e a sua relação com a questão da cidadania;

- no capítulo // - A cidadania: uma problemática da actualidade percorremos um caminho que nos permite compreender as concepções de cidadania, a sua história ao longo dos tempos e o seu conceito. Analisamos ainda a questão da cidadania em

2. Consideramos importante esclarecer que apesar de pensarmos que é fulcral separar a designação dos géneros, com o propósito de proporcionar uma leitura mais coesa e concisa, não utilizamos a duplicidade de género los/as alunos/as; os/as professores/professoras...) sempre que utilizarmos o género masculino, estaremos a referir-nos a ambos os géneros. No entanto, no caso específico das encarregadas de educação, utilizaremos o género feminino por se tratar de mulheres na sua totalidade. 
contexto escolar intercultural, destacando alguns conceitos de educação para a cidadania de acordo com diversos autores, a sua centralidade na reorganização curricular, a problemática dos valores numa educação para a cidadania e, finalmente, reflectimos sobre o papel do professor do $1 .{ }^{\circ}$ CEB na construção da cidadania dos seus alunos;

- no capítulo I/I - Análise da cidadania a partir de legislação e de documentos orientadores - realizamos uma análise à legislação e documentos orientadores das políticas e das práticas educativas e ao currículo enunciado do $1 .{ }^{\circ}$ CEB no sentido de perceber de que forma neles se aborda a questão da cidadania e para compreender a importância da educação para a cidadania democrática no sistema de ensino a nível institucional de modo a dar resposta a este desafio do desenvolvimento de uma cidadania democrática nas escolas portuguesas.

Na Parte II, denominada Contexto da investigação empírica, descrevemos a metodologia adoptada no trabalho em dois capítulos:

- no capítulo IV - Opções metodológicas da investigação - apresentamos a metodologia do trabalho empírico utilizada, definindo e caracterizando a amostra que inclui três grupos distintos: professores, alunos e encarregados de educação, referindo a relação entre eles. Mostramos a nossa opção pela entrevista semi-directiva como instrumento de recolha de dados, salientando alguns cuidados na construção do seu guião e aplicação. Apresentamos ainda os procedimentos e as etapas para a análise da informação por nós adoptados.

Na Parte III, intitulada As vozes dos entrevistados, tentamos interpretar as opiniões dos entrevistados através dos seus discursos expressos nas entrevistas:

- no capítulo V - Análise e interpretação dos resultados da investigação - apresentamos os resultados qualitativos dos três grupos em estudo e fazemos um pequeno cruzamento de alguns dados das entrevistas.

Terminamos este trabalho com as Reflexões e considerações finais que consideramos mais significativas. Também são aí expostos certos aspectos teóricos e práticos mais importantes que os vários capítulos foram abordando. 



\section{PARTE I - ABORDAGEM TEÓRICA EM TORNO DAS MIGRAC̣ÕES, DA COMUNICAÇÃO INTERCULTURAL E DA CIDADANIA \\ CAPÍTULO I - DESAFIOS À SOCIEDADE E À ESCOLA}

\section{NOTAS INTRODUTÓRIAS}

Nas sociedades actuais, numa época de globalização, assiste-se a uma crescente diversidade de culturas devido ao aumento de fluxos de pessoas (com migrações nacionais e internacionais), de serviços, de viagens e redes de comunicação e de informação. É possível constatar esse facto ao olhar para o «arco-íris cultural» (Stoer e Cortesão, 1999) que configura a nossa sociedade para nos apercebermos dessa multiculturalidade.

É possível também constatar esta crescente diversificação cultural nas escolas portuguesas. Este facto deve-se à presença, na escola, de grupos sociais que a ela passaram a recorrer devido à expansão da «escola de massas» e de grupos culturais e étnicos resultantes dos fenómenos migratórios. Neste contexto, espera-se que a escola promova a igualdade de oportunidades, quer ao nível do acesso quer ao nível do sucesso a todas as crianças, respeitando as diferentes culturas com os seus costumes e tradições e que desenvolva práticas de justiça social, solidariedade e respeito por todos os parceiros envolvidos no processo educativo. A instituição escolar vê-se, deste modo, perante a questão de como lidar com diferentes culturas, perante o problema da comunicação entre «diferentes».

\section{AS MIGRAC̣ÕES}

A presença da crescente diversidade nas sociedades é, principalmente, devido à permanente mobilidade das pessoas, por decisão própria ou por força das circunstâncias, individualmente, em pequenos grupos ou em gigantescos êxodos envolvendo nações inteiras, indo de encontro à ideia de Rocha - Trindade (1995:141), ao afirmar que «os movimentos internacionais de população, independentemente das suas causas, tanto próximas como estruturais, conduzem necessariamente à criação de contextos multiculturais».

Consoante a relação de forças entre as sociedades autóctones e as que vieram a com elas contactar a partir de dado momento, assim se verificaram situações de coexistência mais ou menos fácil e mais ou menos 
pacífica, podendo até atingir-se um certo grau de miscigenação ou de integração ou pelo contrário de submissão, de expulsão ou de aniquilação dos dominados pelos dominantes.

De acordo com Jackson (1991:2), «a migração implica o movimento de indivíduos e grupos entre duas sociedades: a que acabaram de deixar e aquela em que procuraram inserir-se». Quando a dimensão destes grupos é suficiente para que constituam sociedades homogéneas e culturalmente diferenciadas em relação à sociedade receptora, poderão vir a constituir entidades permanentes, com as características típicas de uma minoria nacional. O respeito pela equidade de direitos sociais, culturais e políticos das entidades culturais que coexistam no interior do território de um Estado é condição indispensável para a estabilidade deste último.

Quando há a saída de alguém com uma ausência de duração significativa, do país que é seu por relação de nacionalidade e por vivência no território que politicamente lhe está adstrito, designa-se por emigração. Os protagonistas desta acção são designados por emigrantes. 0 emigrante é um nacional ausente, com perda pouco significativa de direitos no país de onde provém e, talvez até, uma certa diminuição dos deveres e obrigações inerentes à sua qualidade de cidadão. Em contrapartida um estranho vindo de fora, encontrando uma sociedade que provavelmente desconhece e onde terá de se inserir, sujeitando-se às leis que a administram, é um imigrante.

Hoje, os termos emigração e imigração tendem a cair em desuso, abdicando-se das suas diferentes significações, passando a ser absorvidos pela designação englobante de migração, simplificando, em síntese, a mesma realidade de situação e de sujeito. Migração é portanto «a existência de movimentos que, de unidireccionais, se transformam tipicamente em oscilatórios, sem distinção explícita entre origem e destino, entre quem parte e quem chega» (Rocha - Trindade, 1995:33).

\subsection{Os principais factores de migração}

A decisão de partir interfere não só com o emigrante, mas toda a sua família alargada e, no caso de já ele próprio ter constituído uma, o seu cônjuge, descendentes e outros dependentes.

As principais causas responsáveis pela deslocação de populações nos tempos mais recentes são a emigração económica e as guerras e conflitos locais que têm eclodido em vários pontos do globo. 
As motivações que os levam a partir não são só de origem individual, mas têm uma provável incidência colectiva. Estas motivações são de origem económica, política, de emergência, étnico-cultural, migrações de quadros, especialistas e outras. As motivações de raiz predominantemente económicas são mais generalizadas. Elas afectam os países mais pobres ou menos desenvolvidos, as regiões mais deprimidas, as classes sociais mais desfavorecidas. A emigração política admite as causas predominantes deste foro, reflectindo desequilíbrios graves entre um sistema político e a aceitação do mesmo pela generalidade dos cidadãos.

Situações de gravidade excepcional são aquelas em que as populações se encontram inesperadamente em situação de total privação de recursos que não asseguram sequer, a sua sobrevivência diária. Esta noção aplica-se a seres humanos, vítimas de grandes catástrofes, como a invasão e a guerra, a fome, os efeitos de terramotos e erupções vulcânicas, etc.

As motivações étnico-culturais «têm a ver com o modo como ao longo da história das nações, as invasões, guerras, tratados internacionais e migrações tiveram como frequente consequência a inclusão de minorias de origem étnica e cultural diferenciada, em sociedades maioritárias de raiz diferente, qualquer ameaça à sobrevivência das primeiras, como entidade cultural individualizada, pode motivá-las a mudar de país» (Rocha - Trindade, 1995:43).

A migração de quadros e especialistas comporta as formas de aliciamento selectivo de determinados grupos profissionais disponíveis num país e cuja falta é reconhecida num outro. Como exemplo, podemos assinalar na actualidade, a emigração de físicos nucleares e cientistas espaciais russos ou a migração de atletas da Europa de Leste para vários países. Porém, este tipo de mobilidade só é considerada como verdadeiro fluxo emigratório quando envolva um número significativo de pessoas e exista uma expectativa da sua radicação a longo prazo ou com duração indefinida.

Para tentar explicar os factores que levam ao aparecimento das migrações, surgiu, em meados do século XIX, uma teoria baseada em factores de atracção e repulsão, tendo em conta os factores que afastavam as pessoas do seu local de origem e os que as atraíam para outros locais. Os factores de repulsão são principalmente de natureza económica e incluem a falta de acesso à propriedade ou ao uso da terra lescassez de terras), os salários baixos, a falta de emprego, as terras improdutivas, as secas e fomes e o crescimento populacional. Os factores de atracção constituem alternativas aliciantes aos de repulsão lemprego, salários 
elevados), acrescentando-(hes as vantagens da vida urbana em contraposição à suposta estagnação vivida nas zonas rurais e o desenvolvimento da tecnologia e do comércio.

A essência deste modelo de atracção/repulsão foi definida por Ravenstein (1885 e 1889), o qual elaborou alguns princípios explicativos dos mecanismos dos processos migratórios (no plano interno e internacional). Porém, as suas duas afirmações mais importantes e relevantes foram as seguintes: o desenvolvimento do comércio e tecnologia leva a um aumento das migrações; a causa económica das migrações é a que tem mais peso entre todas. Este modelo de Ravenstein ainda é actualmente, dentro das teorias baseadas no modelo de atracção/repulsão, a contribuição teórica mais relevante e significativa pois «assume um conjunto de factores associados à área de origem e um outro conjunto de factores associados à área de destino, a que se vão juntar as variáveis intervenientes que afectam, num dado momento, o equilíbrio desses interesses» (Jackson, 1991:21)

Na opinião de Conceição Ramos (1996:254) para a «explicação dos comportamentos migratórios, vários factores actuam e podem intervir de forma diferente ao longo do tempo: a demografia, as diferenças salariais, a distância geográfica, o tipo de inserção local e a dinâmica das relações culturais e sociais». É de salientar também a contribuição dos motivos extra-económicos e o papel importante do funcionamento do mercado de trabalho do país de acolhimento. Podemos considerar igualmente que as migrações são um aspecto da internacionalização do trabalho. Ainda de acordo com esta autora «a amplitude e direcção dos movimentos de população explicam-se pela história, a sociologia (contribuição de redes comunitárias e de associações de migrantes que facilitam o acolhimento), a economia (vantagens das migrações), a política (regulamentação do país de imigração),...» (ibidem).

Segundo Rocha - Trindade (1995:101) «quaisquer que sejam os motivos que possam influenciar a deslocação dos indivíduos de um para outro lugar, a questão do ajustamento dos imigrantes a um novo meio ambiente constitui um dos aspectos fundamentais relativos ao processo migratório»

Dividem-se em dois conjuntos os factores que intervêm no processo de ajustamento dos imigrantes. São eles, os que dizem respeito às características individuais dos migrantes e as que se relacionam com características fundamentais dos países de origem e de destino entre os quais se processa a transferência de recursos humanos. 
Actualmente, o grau de adaptação a uma determinada cultura envolve um ajustamento tanto social como emocional, assim como a aceitação das normas sociais prevalecentes. Os imigrantes respondem de diferentes formas segundo as características individuais, demográficas, económicas e sociais, bem como em função da história e da experiência do grupo a que pertencem.

\subsection{Portugal: país de emigração e de imigração}

Portugal tem sido considerado como país de emigração lmovimentos para fora do local normal de residência, com destino nacional ou internacional). O fenómeno emigratório português tem raízes antigas, a partir do início da colonização da Madeira (cerca de 1425), mas foi na década de sessenta que se iniciou o maior fluxo emigratório de mão-de-obra para países da União Europeia, que teve o seu auge em 1970 e que começou a decrescer a partir de 1973, onde iam ocupar postos de trabalho que os nacionais desses países não aceitavam.

De acordo com Joel Serrão (1985:998 e 999), a emigração portuguesa contemporânea «enquadra-se nos condicionalismos dos países atrasados e, portanto, directa ou indirectamente dependentes dos pólos de desenvolvimento socioeconómico, tecnológico e cultural». Este fenómeno «traduziu-se na drenagem de recursos para os centros mais fortes» (idem: 1004). Este autor refere que entre 1885 e 1973 cerca de 4000000 de pessoas deixaram definitiva ou temporariamente Portugal à procura de melhores condições de vida. Segundo este autor, pode dizer-se que os pólos de atracção principais, foram o continente americano, no qual se destaca o Brasil, e após a II Guerra Mundial, os países da Europa mais industrializados, principalmente a França.

Para Conceição Ramos (1995), depois de 1974, o modelo de emigração mudou passando a verificar-se um aumento do fluxo sazonal, temporário e clandestino para a Europa (principalmente para França e Suíça) nas actividades da construção civil, agricultura, limpeza e hotelaria.

A partir, principalmente, de 1976 é de assinalar o movimento de retorno de emigrantes portugueses na Europa que começaram a regressar às suas terras, fixando-se nas aldeias ou vilas de onde tinham partido, onde geralmente voltam à agricultura e/ou investem em pequenas explorações comerciais. Nos anos oitenta os fluxos migratórios sofreram uma alteração, tal como nos diz Ramos (1995), a emigração portuguesa aumentou, com saídas sobretudo do Norte e Centro do país, a par com uma diminui- 
ção relativa do retorno e o aumento da imigração estrangeira nas zonas urbanas mais desenvolvidas (Lisboa, Porto, Faro e Setúbal).

Apesar de algumas correntes de pensamento considerarem a emigração «como um factor de regulação do mercado de trabalho à escala internacional, com vantagens para ambas as regiões las de acolhimento e as de saída)», Serrão (1985:1004) entende que a emigração se revelou como «um factor entravante do desenvolvimento e deverá ser apontada como um exemplo, entre outros, de crescimento económico com empobrecimento, no que respeita aos países de origem».

Actualmente, pode considerar-se Portugal como um país de emigração e de imigração. Este «novo» contexto da imigração de estrangeiros para Portugal iniciou-se com o recurso a mão-de-obra cabo-verdiana principalmente para a construção civil, nos anos sessenta e início dos anos setenta, mas desenvolveu-se mais ao longo da década de oitenta. De facto, foi, principalmente, a partir dos anos oitenta que Portugal passou a ser o destino escolhido por muitos estrangeiros. Para além de cidadãos vindos dos PALOP e do Brasil, tem vindo a aumentar o número de estrangeiros oriundos da Europa do Leste.

Portugal passou da emigração em massa para uma diversidade de fluxos, onde a imigração ocupa um lugar de destaque. No entanto, não se pode afirmar que Portugal deixou de ser um país de emigração para se tornar um país de imigração, pois após um período de estagnação lentre 1975 e início da década de oitental a emigração portuguesa voltou a crescer, embora não atingindo os valores da década de sessenta.

\subsection{A imigração portuguesa no contexto europeu e mundial}

Os fluxos migratórios em direcção a Portugal inscrevem-se na dinâmica populacional da Europa e do mundo, não constituindo um fenómeno isolado.

As tendências das migrações internacionais não sofreram grandes alterações no final do século XX. Como nos diz Fernando Machado (1997:9) «o vector principal do sistema internacional de migrações continua a ser a seta apontada de Sul para Norte, dos países em vias de desenvolvimento para os países desenvolvidos. Na Europa, este fluxo migratório no sentido Sul/Norte (da Espanha, Portugal, Itália e Grécia para França, Alemanha e países do Beneluxl foi complementado por outros fluxos extra-europeus originários do Magreb e da Turquia, de algumas zonas mais 
povoadas e carenciadas da América Latina e da Ásia, da África subsariana e do Leste Europeu. Deste modo, e na última década a Europa do Sul, sem tradição de imigração, passou a integrar o circuito das rotas migratórias internacionais, quer como zona de fixação, quer como plataforma de passagem de fluxos mais recentes de imigrantes africanos, asiáticos e sul-americanos. Ainda de acordo com este autor, a imigração portuguesa deve ser analisada num quadro mais geral de movimentos de entrada e saída do país, num contexto europeu. Nesse contexto podemos considerar que «nas duas últimas décadas, a imigração é um entre quatro fluxos externos, sendo os outros três a emigração, o regresso de emigrantes e o retorno das ex-colónias» (idem:14).

A chegada de indivíduos estrangeiros veio acentuar o carácter heterogéneo da população que reside no nosso país. Os fluxos migratórios em direcção a Portugal são constituídos por indivíduos de origens geográficas e culturais muito diversificadas, emergindo de conjunturas económicas e políticas diferentes. Convém, pois, identificar as suas origens/ /nacionalidades para uma melhor compreensão da actualidade.

O contingente global dos indivíduos originários dos PALOP (países africanos de língua oficial portuguesal tem vindo a aumentar, no entanto, a evolução quantitativa das várias nacionalidades cresceu a diferentes ritmos. Os imigrantes naturais de Cabo Verde são os mais numerosos e apesar do seu peso relativo ter vindo a diminuir, constituem a maior e a mais antiga comunidade lusófona a residir em Portugal. Os imigrantes provenientes da Guiné-Bissau, de S. Tomé e Príncipe, de Moçambique e de Angola, apresentam uma evolução crescente. De um modo geral, estes imigrantes vindos das ex-colónias portuguesas possuem poucas ou nenhumas habilitações literárias e desempenham tarefas não qualificadas, mal remuneradas e precárias. Com excepção dos imigrantes vindos da Índia (ligados ao pequeno comércio), os homens trabalham na construção civil e obras públicas e nos serviços, as mulheres trabalham no comércio e serviços domésticos. Segundo Perista e Pimenta (1993:437), os imigrantes vindos das ex-colónias portuguesas são «a fracção mais marginalizada dos estrangeiros residentes em Portugal e, simultaneamente, a que apresenta um maior grau de vulnerabilidade à pobreza e à exclusão social. Grande parte destes imigrantes vive em condições socioeconómicas tão precárias e deficientes que pode considerar-se à margem da sociedade envolvente».

Para além dos estrangeiros provenientes dos PALOP, o número de imigrantes vindos do Brasil, América do Norte, do Reino Unido, da Espanha, da Alemanha e da França é muito significativo. Estes imigrantes 
possuem um estatuto socioeconómico e grau de instrução superior ao da maioria dos imigrantes africanos e preenchem quadros mais qualificados de empresas multinacionais devido a novos investimentos estrangeiros direccionados para o turismo, comércio, agricultura e servicicos.

O nosso país, visto como «país tradicional de emigrantes, passou a ser o destino preferido de muitos estrangeiros, principalmente a partir dos anos 80» (Ramos, 2003c:59). Há três tipos de factores que conduziram ao crescimento da imigração nesse período de tempo: o primeiro factor relaciona-se com o mercado de trabalho, havendo uma «sincronia entre o reforço da política de obras públicas, a partir de meados da década de oitenta, e o aumento progressivo do número de imigrantes dos PALOP nesse sector de actividade, sobretudo na região de Lisboa e Vale do Tejo e Algarve» (...), «um segundo factor é de natureza política e tem a ver com a posição do Estado Português. A ausência, durante toda a década de oitenta, de mecanismos de controlo funcionou favoravelmente à entrada de imigrantes, tanto mais quanto os países europeus tradicionalmente receptores haviam já imposto fortes restrições à entrada de estrangeiros extra-comunitários», por último, «o terceiro factor é de natureza eminentemente social e tem a ver com a formação de redes migratórias» (Machado, 1997:23). Estas redes migratórias de relacionamento interpessoal facilitam ao recém-chegado imigrante apoio à instalação e informações sobre o mercado de trabalho, proporcionando, deste modo, o acesso à assistência e à informação. Assim, «quando estas redes se desenvolvem, elas não só apoiam como estimulam novas correntes migratórias, o que contribui para a persistência de determinados fluxos populacionais mesmo quando cessam as condições estruturais que the deram início» (Rocha - Trindade, 1995:91).

Na opinião de Conceição Ramos (1995), existe heterogeneidade na população imigrante que se situa entre quadros muito qualificados (vindos da Europa ou América) e trabalhadores africanos pouco qualificados da indústria. A mão-de-obra vinda de países da União Europeia preenche quadros mais qualificados de empresas multinacionais enquanto a mão-de-obra menos qualificada (vinda sobretudo dos PALOP) está direccionada para a indústria, construção civil e serviços de limpeza. A situação profissional dos imigrantes «deve-se, por um lado, às características desta população (baixo nível de instrução, presença reduzida nos circuitos de formaçãol e, por outro lado, à rigidez da organização do trabalho, que implica a manutenção de um certo número de empregos qualificados, e à posição social do imigrante» (Ramos, 1995:133). 
Os imigrantes mais recentes são de origem mais diversificada como: africanos, asiáticos e sobretudo da Europa de Leste devido não só aos conflitos e às tensões políticas mas em especial às dificuldades económicas que nesses países se vivem e que têm provocado a mobilidade de população originária dessa região. Estes imigrantes chegam clandestinamente ao mercado de trabalho do nosso país e antecipam em grande parte a procura, ocupando os empregos disponíveis ou deixados livres (serviços domésticos, construção e obras públicas). De acordo com dados resultantes da última regularização extraordinária de estrangeiros (Janeiro a Novembro de 2001), «a comunidade ucraniana passou a ser a terceira mais numerosa, logo a seguir aos cabo-verdianos e aos brasileiros» (Ramos, 2003a:264). Se anexarmos às autorizações de permanência, «os cidadãos de nacionalidade estrangeira com estatuto legal de residência em Portugal, os imigrantes legais ultrapassam os 400 mil» (Ramos, 2003c: 59).

Segundo dados do Serviço de Estrangeiros e Fronteiras e de acordo com a análise do quadro I, nos onze principais países de origem dos imigrantes estão incluídos quatro países do Leste Europeu - Ucrânia, Moldávia, Roménia e Rússia. Os números expostos no quadro, referentes às autorizações de permanência, salientam o recente afluxo de população do Leste Europeu para o nosso país.

Quadro I - Autorizações de permanência temporárias concedidas - Portugal Principais 11 países de origem - valores acumulados de Janeiro de 2001 a Maio de 2002

\begin{tabular}{|l|c|}
\hline \multicolumn{1}{|c|}{$\begin{array}{c}\text { Países } \\
\text { de origem }\end{array}$} & $\begin{array}{c}\text { Número de autorizações } \\
\text { concedidas }\end{array}$ \\
\hline Ucrânia & 65148 \\
\hline Brasil & 33053 \\
\hline Moldávia & 13616 \\
\hline Roménia & 10994 \\
\hline Cabo Verde & 7618 \\
\hline Rússia & 7069 \\
\hline Angola & 6810 \\
\hline Guiné-Bissau & 4618 \\
\hline Índia & 4181 \\
\hline Paquistão & 3922 \\
\hline China & 4630 \\
\hline Total Geral & 181060 \\
\hline
\end{tabular}

In: Ramos, 2003b:9. 
Relativamente à população estrangeira residente em Portugal, expomos um quadro que representa, por continentes, os estrangeiros com estatuto legal de residência em Portugal (2001). Cabo Verde e Angola foram as nacionalidades africanas mais expressivas no conjunto dos residentes estrangeiros. A nacionalidade mais representativa do continente americano foi a brasileira. As nacionalidades mais representativas do continente europeu foram o Reino Unido e a Espanha.

\section{Quadro II - Estrangeiros com estatuto legal de residência em Portugal (2001)}

\begin{tabular}{|l|c|}
\hline \multicolumn{1}{|c|}{ Continente } & $\%$ \\
\hline África & 47,8 \\
\hline Europa & 30,0 \\
\hline América & 17,5 \\
\hline Ásia & 4,3 \\
\hline Outros & 0,4 \\
\hline \multicolumn{1}{r|}{ Total } & 100,0 \\
\hline
\end{tabular}

In: Ramos, 2003a: 269.

Apresentamos ainda um outro quadro (quadro III) elaborado a partir de dados retirados do MAI, mas nele apenas constam as nacionalidades englobadas neste trabalho de investigação.

Quadro III - População estrangeira residente em Portugal (proveniente da Bulgária, Moldávia, Rússia e Ucrânia), por nacionalidade e sexo

\begin{tabular}{|l|c|c|c|}
\hline \multirow{2}{*}{ Nacionalidade } & \multicolumn{2}{|c|}{ Sexo } & \multirow{2}{*}{ Total } \\
\cline { 2 - 3 } & Homens & Mulheres & \\
\hline Bulgária & 455 & 239 & 694 \\
\hline Moldávia & 178 & 78 & 256 \\
\hline Rússia & 300 & 539 & 839 \\
\hline Ucrânia & 235 & 269 & 504 \\
\hline
\end{tabular}

Fonte: Ministério da Administração Interna (MAl) - dados provisórios de 2003, processado em 20/02/2004.

Cada vaga de imigrantes, com o decorrer do tempo, tem tendência a integrar-se no mercado de trabalho nacional e o conhecimento da língua do país de acolhimento e o reconhecimento das qualificações obtidas antes 
da imigração são factores que facilitam essa mesma integração. Apesar desta tendência para a integração, «o modelo das migrações de trabalho expõe-se aos riscos de exclusão das 'segundas gerações' e à sua transformação em minorias étnicas» (Ramos, 2003a:144).

\subsection{As políticas de imigração}

As questões relativas à imigração só se tornaram uma temática central no princípio dos anos 90, altura em que «a imigração adquiriu visibilidade e relevância suficiente para ser inserida no quadro das preocupações sociais e legislativas, atenuando-se, assim, a imagem unilateral de Portugal como país de emigrantes» (Ramos, 2003a:265).

A postura da política do Estado Português perante a imigração modificou-se devido a um conjunto de factores que contribuíram para a politização da etnicidade e para a tomada de medidas dirigidas a imigrantes e requerentes de asilo, tais como:

- «a radicação de comunidades imigrantes e o aumento do respectivo peso demográfico;

- a visibilidade social do fenómeno migratório e a percepção política das consequências que, em termos de estabilidade social, podem advir das condições socioeconómicas em que vivem muitos imigrantes;

- o aparecimento de formas organizadas de promoção da defesa dos direitos das populações imigradas junto do governo e da sociedade civil, protagonizadas essencialmente por associações de imigrantes, partidos políticos e organizações não governamentais;

- uma prolongada crise económica, o consequente aumento de desemprego e a crescente fragilidade do sistema de segurança social» (Rocha - Trindade, 1995:206).

Para a mudança da posição política do Estado Português em relação às populações imigradas contribuíram ainda os tratados e acordos assinados internacionalmente. Dentro desses compromissos podemos salientar alguns tais como: a Convenção de Genebra (1954), o Protocolo de Nova Iorque (1967), a Convenção de Dublin (1990) e os Acordos de Schengen, com o objectivo de estabelecer uma política comum no que diz respeito à emissão de vistos, cooperação policial e circulação de pessoas no espaço comunitário. 
A nível nacional podemos referir a nomeação de uma assessora para a Casa Civil do Presidente da República (Março de 1993) para acompanhamento dos problemas das comunidades de imigrantes e o processo extraordinário de legalização de imigrantes clandestinos que ocorreu entre 13 de Outubro de 1992 e 5 de Março de 1993 (Decreto-Lei 212/92 de 12 de Outubro), extensível aos cônjuges e filhos menores de 14 anos.

Relativamente à produção de instrumentos legais, o governo criou um novo regime de entrada, permanência, saída e expulsão de estrangeiros (Decreto-Lei 59/93 de 3 de Março) que visava ainda a constituição de uma Comissão de Imigração, a formação do Conselho Nacional de Imigração e a criação do Instituto de Expulsão Administrativa.

Assinala-se também a resolução do Conselho de Ministros n. ${ }^{\circ}$ 38, de Abril de 1993, na qual foi aprovado um programa de actuação com um conjunto de medidas para os sectores do Emprego e da Formação Profissional, da Educação e da Acção Social.

Na sequência desta resolução foi publicado um Despacho conjunto dos Ministérios da Administração Interna, da Educação, das Obras Públicas, Transportes e Comunicações, da Saúde e do Emprego e Segurança Social la 12 de Outubro de 1993) através do qual foi criada uma Comissão Interdepartamental para a Integração dos Imigrantes e Minorias Étnicas.

Por outro lado, e devido à preocupação com a existência de imigrantes ilegais e com a segurança civil dos portugueses, o Executivo modificou a Lei do Asilo através da Lei n. ${ }^{0}$ 70/93 de 29 de Setembro.

A Lei da Nacionalidade (Lei n. ${ }^{\circ}$ 25/94 de 19 de Agosto) foi também modificada, ficando a obtenção de nacionalidade portuguesa limitada aos indivíduos casados com portugueses pelo menos há três anos e aos nascidos em território português, filhos de estrangeiros residentes legais por um período não inferior a seis anos (para nacionais de países de língua oficial portuguesa) ou dez anos (para nacionais de outros países).

Foi criado o Alto-Comissário para a Imigração e Minorias Étnicas (ACIME), pela Lei Orgânica do Governo, sendo as suas atribuições e competências fixadas pelo Decreto-Lei n. ${ }^{0}$ 3-A/96, de 26 de Janeiro. A criação do Alto-Comissário teve como objectivo acompanhar, a nível interministerial, o apoio à integração dos imigrantes, cuja presença é considerada como um factor de enriquecimento da sociedade portuguesa. Este órgão, dependente da Presidência do Conselho de Ministros, reconhece que «os novos desafios que se colocam a Portugal como país de imigração requerem 
medidas de integração na sociedade das famílias de imigrantes, em geral, das minorias étnicas de forma a evitar situações de marginalização geradoras de racismo e xenofobia» (Leitão, 1999:2). Revela ainda «uma grande preocupação com o sucesso educativo e o sucesso humano dos filhos dos imigrantes» (idem:12). No entanto, pelo Decreto-Lei 251/2002, de 22 de Novembro, é reconhecido que o cargo de Alto-Comissário é insuficiente para atingir as metas propostas relativas à problemática da integração de imigrantes e minorias étnicas. Deste modo, é criado o Alto-Comissariado para a Imigração e Minorias Étnicas, na directa dependência do Primeiro- Ministro, com o carácter de estrutura interdepartamental de apoio e consulta do Governo em matéria de imigracão e minorias étnicas. O Alto- Comissariado para a Imigração e Minorias Étnicas tem como atribuicões, entre outras, promover a integração dos imigrantes e das minorias étnicas na sociedade, respeitando a sua identidade social e cultural e contribuir para a melhoria das suas condições de vida.

Posteriormente, nos termos do Decreto-Lei n. ${ }^{\circ}$ 167/2007, de 3 de Maio, - Alto-Comissariado para a Imigração e Minorias Étnicas adquire novas competências, transformando-se, em união com outras estruturas, num instituto público e passando a designar-se por Alto-Comissariado para a Imigração e Diálogo Intercultural (ACIDI, I. P.). Assim, o ACIDI, I.P. resultou da fusão do Alto-Comissariado para a Imigração e Minorias Étnicas, da estrutura de apoio técnico à coordenação do programa Escolhas, da estrutura de Missão para o Diálogo com as Religiões e do Secretariado Entreculturas. Este instituto público tem como finalidade colaborar na concepção, execução e avaliação das políticas públicas relevantes para a integração dos imigrantes e das minorias étnicas, bem como promover o diálogo entre as diversas culturas, etnias e religiões. O ACIDI, I.P. possui como atribuições, entre outras, favorecer a aprendizagem da língua portuguesa e o conhecimento nossa cultura por parte dos imigrantes, garantir o acesso das minorias étnicas e dos cidadãos imigrantes a informação relativa a direitos e deveres de cidadania e promover a inclusão social de crianças e jovens descendentes de imigrantes e de minorias étnicas, tendo em vista a igualdade de oportunidades e o reforço da coesão social. 
Apresentamos o quadro IV que sintetiza a evolução das políticas de imigração no nosso país, desde 1974 até 2003.

Quadro IV - Políticas de imigração em Portugal

\begin{tabular}{|c|c|c|c|}
\hline Anos & Características & Políticas de Integração & Regulação de Fluxos \\
\hline $\begin{array}{l}1974 \\
a \\
1990\end{array}$ & $\begin{array}{l}\text { Despolitização da Imigração. } \\
\text { Exclusão estrutural (laboral, } \\
\text { social, cultural, marginalização). }\end{array}$ & & $\begin{array}{l}\text { Repatriamento de portu- } \\
\text { gueses residentes nas ex- } \\
\text {-colónias, migrações de } \\
\text { refugiados dos PALOP } \\
\text { e Brasil. }\end{array}$ \\
\hline $\begin{array}{c}1991 \\
a \\
1995\end{array}$ & $\begin{array}{l}\text { Nova legislação sobre imigração } \\
\text { Decreto-Lei n. } 59 / 93 \text { de } 3 \text { de } \\
\text { Março) e modificação da Lei do } \\
\text { Asilo (Lei n. }{ }^{\circ} 70 / 93 \text { de } 29 \text { de } \\
\text { Setembro).Primeiro processo de } \\
\text { regularização extraordinária } \\
\text { (Decreto-Lei n.0 212/92). } \\
\text { Aproximação da legislação portu- } \\
\text { guesa à da União Europeia (com } \\
\text { fortes restrições à entrada de } \\
\text { imigrantes de países terceiros). }\end{array}$ & $\begin{array}{l}\text { Política Assimilacionista/inte- } \\
\text { gracionista são diferencial. } \\
\text { Institucionalização da Imigra- } \\
\text { ção: } \\
\text { - criação de canais institucionais } \\
\text { (nacionais/locais) para a inte- } \\
\text { gração das comunidades mi- } \\
\text { grantes; } \\
\text { - visibilidade do movimento asso- } \\
\text { ciativo migrante; mobilização } \\
\text { da sociedade civil. }\end{array}$ & $\begin{array}{l}\text { Imigrações laborais, imi- } \\
\text { grantes dos PALOP, bra- } \\
\text { sileiros, europeus de } \\
\text { países de leste. }\end{array}$ \\
\hline $\begin{array}{c}1996 \\
a \\
2000\end{array}$ & $\begin{array}{l}\text { Processo de regularização ex- } \\
\text { traordinária (Decreto-Lei n. } \\
\text { 17/96). } \\
\text { Introdução de nova legislação } \\
\text { sobre imigração (Decreto-Lei } \\
\text { n. }{ }^{\circ} 244 / 98 \text { e asilo (Lei n. }{ }^{\circ} 15 / 98 \text { ) }\end{array}$ & $\begin{array}{l}\text { Assimilacionista/Integracionista } \\
\text { /Pluralista. } \\
\text { Alargamento dos direitos de } \\
\text { cidadania às populações mi- } \\
\text { grantes. } \\
\text { Introdução de novas medidas } \\
\text { legislativas nas esferas laboral, } \\
\text { social, educacional e política, } \\
\text { visando uma maior integração } \\
\text { das comunidades migrantes } \\
\text { residentes em Portugal. } \\
\text { Criação de novos canais institu- } \\
\text { cionais: } \\
\text { - Alto Comissariado para a } \\
\text { Imigração e Minorias Etnicas; } \\
\text { - Conselho Consultivo para os } \\
\text { assuntos da Imigração; } \\
\text { - Regime jurídico e de Apoio às } \\
\text { Associações de Imigrantes. }\end{array}$ & $\begin{array}{l}\text { Imigração laboral - imi- } \\
\text { grantes da Europa Central } \\
\text { e de Leste, dos PALOP. }\end{array}$ \\
\hline $\begin{array}{c}2001 \\
a \\
2003\end{array}$ & $\begin{array}{l}\text { Promulgação de nova legislação } \\
\text { sobre entrada, permanência, } \\
\text { saída e afastamento de estran- } \\
\text { geiros do território nacional (Lei } \\
\text { n. }{ }^{\circ} \text { 4/2001). } \\
\text { Introdução de vistos de perma- } \\
\text { nência. } \\
\text { Regularização de imigrantes em } \\
\text { situação ilegal. }\end{array}$ & $\begin{array}{l}\text { Novo regime assente numa polí- } \\
\text { tica de restrições e de controlo } \\
\text { apertado da imigração. }\end{array}$ & $\begin{array}{l}\text { Regulação de fluxos de } \\
\text { acordo com as necessida- } \\
\text { des da economia portu- } \\
\text { guesa e do mercado de } \\
\text { trabalho. }\end{array}$ \\
\hline
\end{tabular}

Fonte: Horta (2003). Seminário de Cidadania e Participação Política do Mestrado em Relações Interculturais. Universidade Aberta. 
Perante este fenómeno da imigração, é imprescindível definir estratégias, consolidadas na clareza de ideias face à diversidade cultural e aos sujeitos pessoais, reflectindo sobre a questão da conflituosidade face aos imigrantes. Nesta ordem de ideias, Alain Touraine 11996, cit. por Peres, 1999:40) declara que «não basta dizer que é preciso integrar os imigrados, é urgente, também, aceitá-los e reconhecê-los».

\subsubsection{As orientações do Conselho da Europa}

Ao constatar que quase todos os países partilhavam de problemas a nível das relações inter-étnicas, o Comité dos Ministros do Conselho da Europa lançou um projecto (que decorreu entre 1987 e 1991) sobre «as relações intercomunitárias», expressão usada para designar «o conjunto de problemas e oportunidades que resultam da interacção entre a população maioritária, ou seja, a população do país de acolhimento, e os diversos grupos de migrantes ou grupos étnicos originários da imigração» (Instituto de Apoio à Emigração e às Comunidades Portuguesas cit. por Rocha - Trindade, 1995:233). As relações intercomunitárias diziam também respeito, para além da integração dos imigrantes, ao modo como a sociedade maioritária se deve comportar perante a presença de grupos étnicos com padrões culturais e práticas sociais diferentes.

O Conselho da Europa salienta também o importante papel dos governos ao nível das políticas sociais e multiculturais e na promoção de iniciativas e projectos nos domínios da formação e da educação. Assim, o Comité de Ministros do Conselho da Europa, no plano educativo, «aponta para a importância da implementação de actividades suplementares de âmbito internacional e sublinha o carácter premente da intensificação de esforços no sentido de aperfeiçoar a prática educativa atendendo à realidade pluricultural das sociedades actuais» (idem:234).

\section{A COMUNICAÇÃO E A COMPREENSÃO INTERCULTURAL}

Como temos vindo a referir, muitas sociedades modernas e industrializadas revelam uma crescente diversidade cultural como resultado das migrações. Nessas sociedades coexistem, relacionam-se e comunicam grupos de pessoas que se distinguem umas das outras a nível étnico.

Partindo do pressuposto de que as relações humanas se alimentam de comunicação podemos considerar que a comunicação recíproca e interpessoal é a base da interacção social, a qual só acontece quando as pes- 
soas trocam mensagens significativas. Deste modo, «a comunicação é um conceito integrador, o qual permite redimensionar e repensar os contactos, as relações entre o indivíduo e a sociedade, entre a sociedade e a cultura» (Ramos, 2001:157). A comunicação faz parte da sociedade humana desenvolvendo-se em diversos contextos e actualmente é «confrontada com profundas modificações relacionadas com a globalização, com as transformações sociais, culturais e políticas, com o aparecimento constante de novos suportes e instrumentos, com o desenvolvimento de novas tecnologias» (ibidem).

Comunicar e avaliarmo-nos a nós próprios e aos outros são tarefas quotidianas complexas mas extraordinariamente importantes para cada um e para a sociedade. A comunicação que se estabelece e as avaliações que se fazem influenciam o comportamento humano, contribuem para a formação da identidade e da personalidade dos indivíduos e simultaneamente contribuem também para a construção das relações sociais.

A comunicação encontra-se «omnipresente» nas nossas sociedades, «é dinâmica, interactiva, irreversível e produz-se num determinado contexto físico e sociocultural» (idem:158). Esse contexto pode influenciar a comunicação pois é portador simbólico de regras, normas, modelos e rituais de interacção.

Assim, podemos considerar a comunicação como um fenómeno social complexo e que cada acto de transmissão de uma mensagem está integrado numa matriz cultural, constituindo, deste modo, «a comunicação social o conjunto de códigos e de regras que tornam possíveis e mantêm as relacões e as interaccões entre os membros de uma mesma cultura ou subcultura» (idem:159). A cultura, que por vezes pode ser fonte de conflitos, de incompreensão e até de discórdia, é também, uma das bases do diálogo, da compreensão e da comunicação entre os povos. Tudo o que se aprende de forma inconsciente e consciente e que se pode comunicar é cultura e é através da sua influência que as pessoas aprendem a comunicar. Sendo assim, parte essencial do ser humano é conservado e transmitido pelo grupo social ao qual pertence. Esta herança social e cultural é composta por informações, actos, comportamentos, símbolos e representações sociais.

De acordo com Natália Ramos (2001:162) «a integração social e cultural do ser humano pode enquadrar-se numa dupla apropriação:

- A apropriação do indivíduo pelo conjunto das estruturas simbólicas de um contexto social e cultural particular (...); 
- A apropriação pelo indivíduo das estruturas simbólicas, do código cultural do contexto sociocultural no qual se desenvolve $(\ldots) \gg$.

Portanto, o ser humano não é apenas o produto da sua cultura, pois simultaneamente também a constrói e reconstrói de acordo com os problemas que enfrenta e das estratégias variadas que existem.

Dado que a cultura é comunicação, acção e interacção, ela implica mudança e evolução, que resultam das transformações e das inovações internas de um grupo e dos processos externos causados pelo contacto com grupos culturais diferentes. Na opinião de Banks e Lych (1986, cit. por Ferreira, 2003:52) este processo de aculturação «tem lugar quando a cultura de um indivíduo ou de um grupo se modifica em contacto com outra cultura. Quando diferentes culturas entram em contacto, exercem influência umas nas outras e, consequentemente, ocorre uma troca de elementos culturais». Podemos ainda acrescentar que a aculturação é «um processo por que passam as pessoas, frequentemente já na idade adulta, em reacção a uma mudança de contexto cultural», sendo, deste modo, «uma forma de mudança cultural suscitada pelo contacto com outras culturas» (Neto, 2002:246). As atitudes em relação à aculturação indicam o modo como a pessoa ou o grupo em aculturação deseja relacionar-se com a sociedade receptora. 0 autor Félix Neto (2002:262 e 263) refere um modelo ideal com quatro possíveis «modos de aculturação: assimilação, integração, separação e marginalização». A assimilação implica o abandono da própria identidade cultural em favor da identidade cultural comunidade dominante; a integração implica a manutenção parcial da identidade cultural do grupo minoritário juntamente com uma participação cada vez mais acentuada no seio da sociedade dominante; na separação a pessoa ou grupo cultural não procura estabelecer relações com a comunidade dominante e preserva a sua identidade cultural; por último, a marginalização implica a perda da identidade cultural da pessoa ou do grupo minoritário, que não tem o direito de participar no funcionamento das instituiç̃̃es e na vida do grupo dominante devido a práticas discriminatórias. Para Perotti (cit. por Clanet, 1990:64), «0 conceito de integração opõe-se à noção de assimilação e indica a capacidade de confrontar e mudar - numa posição de igualdade e participação - valores, normas, modelos de comportamento, tanto da parte do imigrante como da sociedade de acolhimento».

Para Natália Ramos (2001:166), «a comunicação intercultural envolve os problemas e processos de interacção verbais e não verbais entre indivíduos pertencentes a grupos ou subgrupos culturais diferentes em 
contextos situacionais variados e a variação cultural na percepção dos objectos e dos acontecimentos sociais». As pessoas de diferentes culturas ou subculturas perante as mesmas realidades podem-lhes atribuir diferentes significados e produzir diferentes percepções sociais. A cultura influencia o modo como cada um de nós selecciona, avalia e organiza as informações e os estímulos que nos rodeiam, levando a que se produzam mais percepções do mundo exterior. Os nossos sistemas de valores, crenças e atitudes, o modo como olhamos e compreendemos o mundo e os outros, têm influência sobre as nossas percepções. Quando o universo de significações não é partilhado, a comunicação é estabelecida com mais dificuldade (como referimos anteriormente). Desse modo, as pessoas com diferentes culturas ou subculturas de origem são forçadas a aprender a integrar as regras culturais e a descentrarem-se em relação à sua própria cultura, numa situação de comunicação intercultural.

No âmbito da comunicação e das relações interculturais uma das dificuldades do ser humano é a descentração, ser capaz de sair do etnocentrismo. O etnocentrismo «refere-se à tendência para julgar/apreciar os valores, atitudes, comportamentos e características de outros grupos culturais tendo como referência características e pontos de vista da cultura do observador» (Cardoso, 1996:15). A cultura, os quadros de referência e o seu próprio conjunto de valores é o contexto que o observador utiliza para julgar todos os outros. Estes são considerados mais ou menos desenvolvidos conforme estão mais ou menos próximos dos padrões culturais do observador. O etnocentrismo constitui um obstáculo à comunicação intercultural e é uma atitude típica dos assimilacionistas, os quais advogam que a assimilação implica o abandono da própria identidade cultural dos grupos minoritários em favor da cultura da comunidade dominante, como já referimos anteriormente.

Quando as representações sociais e significados atribuídos à realidade são diferentes entre as pessoas que estabelecem a comunicação, esta é afectada através dos juízos etnocêntricos, das percepções, dos preconceitos e dos estereótipos. Em muitas situações, as atitudes etnocêntricas dos cidadãos da sociedade receptora podem causar preconceito e discriminação em relação a pessoas vindas de outros países. De facto, «esta falta de respeito pelas crenças e valores culturais e a discriminação resultante por parte da comunidade receptora, pode estar entre as principais causas de dificuldades de adaptação dos recém-chegados» (Neto, 2002:256).

De acordo com Américo Peres (1999: 39), «falar de identidade cultural, cultura, integração e comunicação, significa entrar no mundo dos problemas dos migrantes. Significa ainda, de acordo com este autor, «detectar 
um processo de aculturação (...), imposto, muitas vezes, pela visão etnocêntrica da sociedade de acolhimento, em que os problemas da educação escolar e profissional são evidentes».

Para uma melhor compreensão do conceito de etnocentrismo convém definir alguns termos com ele relacionados. Assim, podemos definir os estereótipos como «imagens-rótulos que as pessoas de um grupo/cultura atribuem às pessoas de outro grupo/cultura baseadas em argumentos não comprovados. (...) Os estereótipos podem ser positivos ou negativos e são aplicados a todos os membros do grupo sem consideração por diferenças individuais» (Cardoso, 1996:18). Por outro lado, os preconceitos «são opiniões pré-concebidas rígidas, geralmente desfavoráveis, em relação a indivíduos ou grupos, formadas sem consideração pelos factos, pela experiência ou informação adequadas de base a um julgamento racional, levando, geralmente, à discriminação, ao tratamento desigual daqueles indivíduos ou grupos» (ibidem). Por último, a discriminação tem sido definida como «actos intencionais que esboçam distinções injustas ou injuriosas, que assentam unicamente em bases raciais ou étnicas» (Neto, 2002:258).

Na opinião de Natália Ramos (2001:168-169) «os estereótipos e os preconceitos podem constituir obstáculos à comunicação intercultural, quando escondem a realidade, as características dos indivíduos ou dos grupos de outras culturas ou subculturas através de generalizações abusivas, porque impedem as mensagens de serem bem recebidas ou emitidas e podem influenciar as percepções».

Para poder compreender o «outro» não só é necessário falar a sua língua para o ouvir e perceber, mas é também conhecer a sua cultura, o seu contexto, a sua mentalidade, porque existem significados que ficam subjacentes ao discurso verbal, tão ou mais importantes para a descodificação da mensagem.

Deste modo, e para facilitar a comunicação intercultural, é necessário aprender a reconhecer a presença da diversidade de pensamento das diferentes culturas ou subculturas. Esta atitude leva-nos ao conceito de relativismo cultural, o qual sugere que «as características de uma cultura devem ser julgadas/apreciadas de acordo com pontos de vista e critérios inerentes à própria cultura e não com base em critérios valorativos estranhos e inerentes a outra cultura» (Cardoso, 1996:15). Assim, as culturas devem ser compreendidas em função das suas próprias preocupações e não através de critérios derivados das preocupações específicas da civilização ocidental. 
Do relativismo cultural podemos salientar as seguintes ideias: não há culturas superiores e inferiores, todas são equivalentes entre si; cada cultura tem especificidades próprias que resultam de percursos históricos que definem a identidade dos seus possuidores; o verdadeiro conhecimento de uma determinada cultura só pode ser atingido através de critérios e estruturas conceptuais próprios, sem a imposição de critérios externos ou a comparação com padrões de julgamento externos.

Ao constatar que as sociedades se estão a tornar cada vez estão mais receptivas à migração multinacional e mais multiculturais no sentido de incluírem mais do que uma comunidade cultural que pretende sobreviver, Charles Taylor (1994:93) ressalta que a necessidade de «vivermos juntos, tanto em harmonia numa sociedade, como à escala mundial, é cada vez maior» e exige que todos reconheçam o valor das diferentes culturas, que as deixemos não só sobreviver mas também admitamos o seu mérito. Deste modo, devemos ter igual respeito por todas as culturas ao usufruir do pressuposto de que todas as culturas têm valor e ao respeitar as diferenças culturais, as quais devem ser tidas em conta pelas «políticas de reconhecimento». A política de reconhecimento de Taylor não só se detém na correcção de uma desigualdade ou discriminação prévias como também passa à afirmação e estímulo das diferenças, à discriminação para diferenciar e à promoção de um cidadão diferenciado. Deste modo, partindo da aceitação da pluralidade cultural, devemos assegurar a necessidade de reconhecimento da identidade cultural, para que as diferenças possam ser manifestadas afirmativamente. De acordo com este autor, «o não reconhecimento ou o reconhecimento incorrecto podem afectar negativamente, podem ser uma forma de agressão, reduzindo a pessoa a uma maneira de ser falsa, distorcida, que a restringe» (idem:45). O autor defende o respeito devido é uma necessidade humana vital e a valorização da identidade cultural é imprescindível para a formação da personalidade do ser humano. Este autor considera ainda que a posição que assumimos quando nos dedicamos ao outro deve basear-se no pressuposto do valor. Esta posição não exige «juízos de valor peremptórios e falsos, mas uma disposição para nos abrirmos ao estudo comparativo das culturas do tipo de nos obrigar a deslocar os nossos horizontes nas fusões resultantes» (Taylor, 1994:93 e 94). Acima de tudo, este autor exige que admitamos estarmos muito aquém desse último horizonte que poderá tornar evidente o valor relativo das diferentes culturas.

Perante uma sociedade caracterizada pelo pluralismo cultural, há que encontrar políticas e tipos de comunicação interculturais, não apenas multiculturais, pois, caso contrário, reproduzem-se as diferenças fecha- 
das em «guetos«, reconhecendo-se-lhes as suas identidades próprias e particularidades sem as pôr em pé de igualdade ao acesso à cidadania europeia e até mundial.

As diferenças étnicas, ao nível das relações intergrupais, raramente assumem um carácter neutral e ao destacarem certos grupos culturais do contexto sociocultural envolvente e que podem levar a situações de auto-segregação e/ou de marginalização cultural, económica ou social por parte do grupo maioritário receptor la marginalização implica a perda da identidade cultural do grupo não-dominante, o qual não tem direito de participar no funcionamento das instituições e na vida do grupo dominante, devido a práticas discriminatórias). Essas diferenças, geralmente, estão associadas a desigualdades de oportunidades de acesso à riqueza e ao poder económico, a diferenças de estatuto e de prestígio social que podem conduzir a relações de tensão e à eclosão de conflitos.

Por outro lado, e apesar da posição menos favorecida das minorias étnicas e dos imigrantes no país receptor, por vezes existe a ideia de que esses grupos podem constituir uma ameaça para a estabilidade social e um factor de aumento da taxa de desemprego. Desta situação podem resultar sentimentos de intolerância e atitudes e comportamentos de discriminação étnica por parte da população da sociedade receptora, o que conduz ao aparecimento de legislação restritiva da entrada de estrangeiros e da expulsão dos indivíduos em situação ilegal. Estas medidas, quando levadas ao extremo, «poderão originar a violação de Direitos Humanos e contribuir para a instalação de um clima mais acentuado de xenofobia e de racismo» (Rocha - Trindade, 1995:231). No entanto, no nosso país, estes fenómenos sociais de racismo e xenofobia são pouco expressivos. Mesmo com o aumento da diversidade cultural devido à crescente imigração, não são visíveis situações de conflito organizado e aberto como as que acontecem em outros países da Europa.

De acordo com Natália Ramos (2001), para desenvolver as aptidões de comunicação intercultural e a compreensão intercultural é preciso desenvolver a compreensão da cultura e dos processos do seu funcionamento; aprender a conhecer-se a si mesmo e à sua própria cultura; aprender a descobrir e conhecer os quadros de referência e os códigos culturais dos outros; evitar os julgamentos superficiais e rápidos, os estereótipos e as atitudes etnocêntricas; desenvolver a empatia e as capacidades empáticas; dispor de tempo para compreender uma situação, para comunicar e estar atenta às mensagens da comunicação não verbal, respeitando os ritmos e estilos de comunicação próprios da pessoa e da 
cultura; desenvolver estratégias e intervenções educativas interculturais; desenvolver estratégias e intervenções educativas/pedagógicas desde a infância e, por fim, implementar uma formação adequada dos professores, uma revisão dos programas e materiais didácticos e usar de modo adequado os meios de comunicação social (os media audiovisuais).

\section{A ESCOLA E A DIVERSIDADE CULTURAL}

Os novos desafios que se colocam ao nosso país, como país de imigração, exigem medidas de integração na sociedade portuguesa das famílias de imigrantes, de modo a evitar e prevenir situações de marginalização, geradoras de racismo e xenofobia. Esta integração diz respeito à criação de condições de vida mínimas de modo a permitir uma participação na vida da sociedade portuguesa e à possibilidade de afirmação da sua identidade cultural.

Enquanto forma de aculturação, é preferível a integração em detrimento da assimilação e da marginalização, pois a integração pressupõe a manutenção parcial da identidade cultural do grupo, juntamente com uma participação mais acentuada no seio da sociedade de acolhimento e deve ser entendida numa perspectiva intercultural. Na continuação da integração há consequências para ambas as partes envolvidas, a sociedade dominante e o grupo em aculturação. Para o grupo em aculturação, a mudança de alguns aspectos da sua cultura, que são valorizados, mas não são adaptativos, para a sociedade dominante, a alteração dos currículos das escolas. Contudo, «os custos da não adopção de políticas de integração são provavelmente ainda maiores, em especial, se o resultado final é a segregação e a marginalização» (Ramos, 2003a:263).

A compreensão e análise das mudanças ocorridas na nossa sociedade cada vez mais multicultural são necessárias para a construção de processos, em variados domínios, promotores da igualdade de oportunidades. No que diz respeito à igualdade de oportunidades ${ }^{3}$ e de sucesso educativo $^{4}$, espera-se que a escola e os seus professores, na sua tarefa de

3. Igualdade de oportunidades «significa que, perante a lei (Constituição, Lei de Bases do Sistema Educativo, etc.) todos os indivíduos, independente-mente das suas condições socioeconómicas, étnicas e culturais, têm direito de ingressar, participar no sistema educativo e dele beneficiar» (Cardoso, 1998:21).

4. Considerando o sucesso escolar não apenas como «uma satisfação dos rituais da profissão de aluno, mas, também e sobretudo como a apropriação dos conteúdos cognitivos e culturais» (Apap, 2002:40). 
educar para uma cidadania democrática, estejam atentos às complexidades dos movimentos demográficos, às suas realidades sociais e às relações entre culturas e pessoas.

É necessário ter em conta as situações de desigualdade e de injustiça sociais e tentar efectivar o direito à igualdade de tratamento e à afirmação das diferenças.

A existência destas populações imigrantes com dificuldades de integração em risco de exclusão social, associadas a baixo nível socioeconómico, faz-nos reflectir sobre o modo como o sistema educativo português pode proporcionar a igualdade de oportunidades no acesso e no sucesso educativo às crianças filhas dos imigrantes. Por outro lado, as condições de inserção e o sucesso ou insucesso dessas crianças na escola também nos faz reflectir sobre as políticas educativas dos últimos anos e leva-nos a questionar em que medida elas estão abertas para a nova realidade escolar provocada pelo aumento da imigração e pelo reagrupamento familiar.

Nas nossas escolas do 1. ${ }^{\circ}$ CEB (grau de ensino sobre o qual incide o nosso trabalhol assiste-se actualmente a uma crescente diversificação devido à fixação de populações migrantes que saíram dos seus países de origem procurando no nosso país melhores condições económicas ou que aqui encontraram refúgio devido a guerras, conflitos e perseguições políticas. A escola vê-se assim confrontada com a heterogeneidade cultural e linguística das crianças oriundas das famílias migrantes.

As migrações apresentam um desafio à instituição escolar de que os esforços de integração devem continuar, pois as vantagens do pluralismo são imensas. No entanto, a educação das crianças filhas de imigrantes e as suas dificuldades de integração escolar «implicam a tomada em conta de um conjunto complexo e indissociável de factores socioeconómicos, culturais, políticos e pedagógicos (...) implicam ainda oferecer à criança migrante um ambiente social, psicológico, familiar e pedagógico-escolar capaz de transformar o risco que comporta a situação migratória num processo estruturante, dinamizador e criativo, implicam ainda a adopção de estratégias e de políticas educativas, sociais e de saúde adequadas e coordenadas» (Ramos, 1999:98). Conceição Ramos (1996) salienta ainda que actualmente a formação e integração socioprofissional de populações migrantes e de minorias étnico-culturais assume importância crescente, constituindo um desafio ao sistema educativo e ao dinamismo das relações profissionais. Na integração escolar e também profissional dessas populações existem importantes factores que não devem ser esque- 
cidos, tais como, «a aposta na formação de professores, na pedagogia intercultural, no privilegiar das opções vocacionais da população migrante e das suas realidades linguísticas e sócio-culturais, no conhecimento das situações experimentadas no país de origem e da cultura de cada uma das comunidades» (Ramos, 2003a:271).

Muitos alunos pertencentes a esses grupos culturais-étnicos revelam dificuldades na sua vida escolar «devido a problemas relacionados com o domínio da língua do país de acolhimento, e as estratégias inadequadas utilizadas pelos professores na sala de aula, aliada à não compreensão, por parte destes e dos colegas, das diferenças culturais que são características dos grupos étnicos a que pertencem» (Ferreira, 2003:50).

Dado que, de uma forma geral, a maior parte das populações imigrantes integra camadas sociais mais desfavorecidas, os progenitores dessas crianças possuem baixos níveis de escolaridade que condicionam a integração social e profissional, o que limita a obtenção de condições materiais (habitação condigna, alimentação equilibrada, material escolar, ...) e humanas (fracas aptidões intelectuais, pouco tempo disponível para acompanhar a vida escolar dos filhos, ...) necessárias para uma aprendizagem com sucesso.

Estas condições e o «desfasamento entre a cultura de origem dos filhos de imigrantes e a da sociedade de acolhimento, reproduzida e representada pela escola, leva frequentemente a que muitos deles constituam casos de insucesso, absentismo e abandono escolar» (Rocha - Trindade, 1995:250).

Para Fernando Machado (1996), a atitude da escola e dos professores face ao bilinguismo das crianças filhas de imigrantes é um factor que interfere no desenvolvimento do processo de escolarização. A aprendizagem do Português é um factor indispensável para a integração bem sucedida dessas crianças na sociedade portuguesa, no entanto alguns preconceitos, ainda disseminados no corpo docente, face às crianças que iniciam a sua frequência escolar com dificuldades na língua portuguesa prejudicam o primeiro contacto desses alunos com a escola e não contribuem para o prosseguimento bem sucedido do seu trajecto escolar futuro. A plena integração e participação individual nas sociedades actuais confronta os seus membros, «em diferentes esferas da vida quotidiana, com tarefas complexas, cuja resolução faz apelo a competências de leitura, escrita e cálculo sempre progressivas e bastante superiores às de duas ou três décadas atrás» (Machado, 1996:235). Este autor considera que o que está em causa é a relação de dupla face entre cidadania e literacia. «0 estado 
da literacia nas comunidades migrantes traduz o confinamento da maioria dos seus membros a circuitos sociais informais e auto-suficientes, marginalizados e marginalizadores, onde a coesão intragrupo pode ser intensa, mas que não asseguram integração social. (...) 0 atrofiamento da cidadania, enquanto sistema de direitos e deveres, é exemplarmente representado pelas inúmeras situações de ausência simultânea de contrato de trabalho, declaração fiscál de rendimentos e descontos para a segurança social ou pela permanência de muitas situações de clandestinidade» (idem: 236 e 237).

De acordo com dados do Ministério da Educação (Secretariado Coordenador dos Programas de Educação Multicultural), no ano lectivo de 1993/94, o número de crianças estrangeiras nas escolas aumentou, vindas das ex-colónias, da Índia e de outros países europeus.

Com base em dados do Ministério da Educação (Base de Dados Entreculturas), apurou-se que no ano lectivo de 1994/95 estavam matriculadas nas escolas públicas portuguesas (nos três ciclos do ensino básico e secundário) 93.668 alunos de nacionalidade estrangeira, «o que corresponde a $6,6 \%$ do universo de alunos inscritos» (Rosa, 2002:353).

No ano lectivo de 1997/98 a percentagem de alunos não lusos matriculados elevou-se para «7,1\% da população escolar portuguesa» (ibidem). Trata-se de um número considerável de crianças e jovens de culturas diversas nas escolas portuguesas.

\subsection{A interculturalidade nas escolas portuguesas}

A interculturalidade na escola tem vindo a ser estudada através do Secretariado Entreculturas que foi criado em Fevereiro de 2001 e que sucedeu ao Secretariado Coordenador dos Programas de Educação Multicultural, criado em 1991.

A última actualização da base de dados data do ano lectivo de 1997/98 (quadro V) e como tal, encontra-se já desactualizada porque não nos permite conhecer o número actual de alunos provenientes da Europa de Leste, cujo peso quantitativo tem vindo a aumentar, número esse que era importante conhecer bem como as escolas por eles frequentadas. 
Quadro V - Situação escolar dos alunos por grupos étnicos e nível de ensino - Ano lectivo de 1997/98 (Portugal - Continente)

\begin{tabular}{|l|c|c|c|c|r|}
\hline \multirow{2}{*}{ Grupo Étnico } & \multicolumn{4}{|c|}{ Ciclos de Escolaridade } & \multirow{2}{*}{ Total } \\
\cline { 2 - 5 } & $1 .{ }^{\circ}$ Ciclo & $2 .{ }^{\circ}$ Ciclo & $3 .{ }^{\circ}$ Ciclo & Secundário & \\
\hline Cabo-verdianos & 6170 & 2663 & 2637 & 921 & 12410 \\
\hline Guineenses & 1507 & 612 & 643 & 388 & 3156 \\
\hline São-tomenses & 897 & 416 & 521 & 299 & 2136 \\
\hline Angolanos & 5649 & 2565 & 3327 & 2582 & 14150 \\
\hline Moçambicanos & 1099 & 763 & 1169 & 1339 & 4377 \\
\hline $\begin{array}{l}\text { Indianos } \\
\text { e Paquistaneses }\end{array}$ & 541 & 258 & 244 & 122 & 1165 \\
\hline Macaenses & 90 & 50 & 64 & 41 & 245 \\
\hline Timorenses & 136 & 52 & 75 & 66 & 329 \\
\hline Ciganos & 5420 & 374 & 102 & 16 & 5930 \\
\hline Ex-emigrantes & 7029 & 4199 & 7816 & 5850 & 25101 \\
\hline Brasileiros & 841 & 595 & 1056 & 1043 & 3542 \\
\hline $\begin{array}{l}\text { Provenientes } \\
\text { da União Europeia }\end{array}$ & 2250 & 1911 & 2931 & 2892 & 10026 \\
\hline Outros & 2915 & 1849 & 2647 & 2139 & 9577 \\
\hline
\end{tabular}

Fonte: Base de dados Entreculturas; dados cedidos por Ana Maria Braga In: Ferreira, 2003:88

Através da análise deste quadro da base de dados Entreculturas sobre a situação escolar dos alunos por grupos étnicos e nível de ensino, podemos verificar que os grupos mais numerosos são os dos angolanos, seguidos dos cabo-verdianos, ciganos, moçambicanos, guineenses, são-tomenses, indianos e paquistaneses, timorenses e macaenses.

Com base em dados mais recentes, do ano lectivo 1999/2000, relativos apenas a alunos matriculados no Ensino Básico Regular - $1 .{ }^{\circ}$ ciclo apresentamos o seguinte quadro (quadro VI), onde podemos observar um grande número de alunos estrangeiros a frequentar o $1 .{ }^{\circ} \mathrm{CEB}$. 


\section{Quadro VI - Alunos matriculados no Ensino Básico Regular - $1 .{ }^{\circ}$ ciclo Ano lectivo de 1999/2000 (Portugal - Continente)}

\begin{tabular}{|l|r|r|r|r|r|r|}
\hline $\begin{array}{l}\text { Grupo } \\
\text { Cultural } \\
\text { Nacionalidade }\end{array}$ & Norte & Centro & $\begin{array}{r}\text { Lisboa } \\
\text { e Vale } \\
\text { do Tejo }\end{array}$ & Alentejo & Algarve & Total \\
\hline $\begin{array}{l}\text { Emigrante } \\
\text { retornado }\end{array}$ & 2936 & 2808 & 1101 & 143 & 198 & 7186 \\
\hline Etnia cigana & 1646 & 1124 & 2561 & 820 & 469 & 6620 \\
\hline Angola & 314 & 368 & 4891 & 38 & 299 & 5910 \\
\hline Brasil & 240 & 170 & 529 & 24 & 62 & 1025 \\
\hline Cabo Verde & 80 & 34 & 5212 & 25 & 295 & 5648 \\
\hline Guiné-Bissau & 68 & 95 & 4756 & 7 & 38 & 1964 \\
\hline Índia & 14 & 9 & 436 & 1 & 14 & 501 \\
\hline Macau & 16 & 19 & 78 & - & 4 & 117 \\
\hline Moçambique & 56 & 63 & 793 & 22 & 38 & 972 \\
\hline $\begin{array}{l}\text { São Tomé e } \\
\text { e Príncipe }\end{array}$ & 16 & 23 & 1080 & 2 & 7 & 1128 \\
\hline Timor & 803 & 663 & 708 & 120 & 621 & 2915 \\
\hline $\begin{array}{l}\text { União Europeia } \\
\text { (estrangeiros) }\end{array}$ & 677 & 616 & 1120 & 143 & 116 & 2622 \\
\hline Outros & 1 & 116 & - & 2 & 122 \\
\hline
\end{tabular}

Fonte: Ministério da Educação/Estatísticas

\subsection{As políticas de educação face à diversidade cultural}

A interacção entre pessoas pertencentes a culturas distintas não se consegue apenas pelo seu contacto e aproximação, mas por políticas e estratégias de educação e formação que possibilitem a permeabilidade cultural, de modo a que todos se sintam culturalmente identificados e socialmente integrados. Porém, as medidas de política educativa e cultural que existem para enfrentar a realidade acima descrita, variam em função do contexto político, ideológico, histórico e sócio-demográfico de cada país.

As principais diferenças dessas políticas estão no modo escolhido para gerir as diversidades existentes na escola: «algumas desenvolvem-se 
no sentido de eliminar as características particulares dos grupos minoritários ou de criar, mediante a sua função, uma cultura homogénea (políticas assimilacionistas); outras, no de respeitar e valorizar essas características, tentando assim responder às necessidades educativas de todos os elementos da população escolar (políticas multiculturais); outras, ainda, no de criar capacidades de relacionamento com pessoas de diferentes culturas e, através da negociação interpessoal, construir espaços de entendimento recíproco (políticas interculturais) » (Rocha - Trindade, 1995:2511.

Em Portugal, antes da década de 70, as políticas educativas orientavam-se face à diversidade, pelo princípio da assimilação, enfatizando a hegemonia social. Nos finais dos anos 80, início dos anos 90, o Ministério da Educação produz discursos de igualdade de oportunidades e de respeito pela diversidade cultural orientados para a compreensão do fenómeno do multiculturalismo e para uma intervenção educativa que respondesse às características plurais dos estudantes.

A aprovação da Lei de Bases do Sistema Educativo, em 1986, foi um acontecimento importante para a educação, pelas medidas que implementou e pelas opções políticas que exprime. Os princípios que caracterizam esta lei foram de encontro aos discursos da época de crítica à escola tradicional, aos princípios de uma ideologia democratizante e aos compromissos assumidos internacionalmente. Um exemplo destes compromissos é a Declaração Universal dos Direitos Humanos (1948), aprovado no âmbito da $\mathrm{ONU}$ e que explicita o princípio da igualdade face à educação escolar.

Segundo Carlinda Leite (2002:288), o reconhecimento pelo sistema do cenário multicultural nas escolas começou com a Reforma Educativa que defendia uma «escola para todos» que se tornou mais visível com: «1) a criação, em 1991, do Secretariado Coordenador dos Programas de Educação Multicultural ${ }^{5}$; 2) a institucionalização, em 1993, de um projecto de Educação Intercultural (PREDI); 3) a criação, em 1996, do cargo de Alto Comissário para a Imigração e Minorias Étnicas; 4) o reconhecimento da educação inter/multicultural como uma área de formação prioritária nas candidaturas ao abrigo do Regulamento de Equiparação a Bolseiro; 5) a constituição de um grupo de trabalho para estudar medidas a implementar no sistema escolar para criar oportunidades de igualdade e inserção dos ciganos».

5. Designado como Secretariado Entreculturas. Este secretariado desenvolveu diversas actividades e foi o impulsionador do PREDI e da criação da Associação de Professores para a Educação Intercultural (APEDI) em 1993. 
Ao nível do poder central, podemos referir outras medidas institucionais tais como: o projecto «A Escola na Dimensão Intercultural» em 1990, o projecto «Pelas Minorias» em 1998, a institucionalização da diversidade religiosa nas escolas públicas (Decreto-Lei n. ${ }^{\circ} 329 / 98$ de 2 de Novembro) e a criação do Grupo de Trabalho Para os Mediadores Culturais através do Despacho conjunto n. ${ }^{0} 1165 / 2002$.

Esta reforma do Sistema Educativo Português iniciou-se no Ministério de Roberto Carneiro que implementou um discurso dirigido para a problemática da multiculturalidade sendo um elemento promotor da criação de projectos relacionados com a problemática do direito à diversidade na educação escolar. Para Carlinda Leite (2002:311), os diplomas que configuram o início da Reforma Educativa e da Reforma Curricular não explicitaram discursos a nível do multicultural, «apenas na Lei de Bases do Sistema Educativo é expresso o desejo de uma formação onde se inter- relacionem a cultura escolar e a cultura do quotidiano sem, no entanto, enunciar que essa cultura do quotidiano é atravessada por aspectos que advêm das diversidades étnicas, religiosas, linguísticas, etc.». A autora, após uma análise do Decreto-lei n. ${ }^{0}$ 286/89 (Reforma dos Planos curriculares do Ensino Básico e Secundário), concluiu que existe aceitação da diversidade e a intenção de promover o sucesso educativo de todos os alunos e o reconhecimento da existência de diferentes religiões. No entanto, é só nos Programas do 1. CEB (1990) que são referidas outras culturas da comunidade e o conhecimento dos seus costumes, gastronomia, língua, música, mas limitando-se a uma folclorização das diversas culturas.

Na opinião de Leite (2002), o quadro legal e os discursos da política educativa valorizam e indicam uma educação intercultural como preventiva de fenómenos de exclusão mas ao nível da operacionalização desse discurso, na prática, existem desencontros. Deste modo, a reforma gerou «mais uma mudança dos discursos do que da agência ou seja da actuação dos seus destinatários» (Leite, 2002:561).

No plano internacional, as directrizes produzidas inicialmente por organizações internacionais IOCDE, UNESCO, Conselho da Europa e União Europeial inicialmente tinham «como objecto privilegiado de intervenção as crianças e os jovens filhos de imigrantes que afluíam às sociedades industrializadas», focando apenas aspectos relacionados com o domínio da língua (idem:336). Estas directrizes foram evoluindo, passando a ter em «conta todas as minorias e dando origem a uma educação para a multiculturalidade» (ibidem). Esta intervenção educativa deixou progressivamente «de ser dirigida apenas às minorias latitude hoje considerada como indiciadora de uma visão patológica ou deficitária dessas minorias) 
e foi-se estendendo também às maiorias (no sentido de as informar e formar para a vivência numa sociedade multicultural)» (ibidem). No intuito de ilustrar a contribuição das organizações internacionais, apresentamos, resumidamente, as suas posições perante a diversidade cultural, em contexto educativo.

A UNESCO lOrganização das Nações Unidas para a Educação, a Ciência e a Cultural, que tem como um dos seus objectivos assegurar os direitos do Homem e das liberdades fundamentais para todos sem distinção de raça, língua ou religião, distingue-se pelo seu dinamismo na área da educação multicultural através da promoção de estudos e encontros e da edição de variadas publicações sobre esta questão. Esta organização foi também responsável pela produção de dispositivos legais como por exemplo a Convenção sobre discriminação na Educação (1960) que promove a igualdade de oportunidades à educação.

A OCDE (Organização de Cooperação e de Desenvolvimento Económico) tem desenvolvido projectos de investigação e estudos comparativos com o objectivo de «conhecer e avaliar as acções realizadas neste campo nos diversos países membros, nomeadamente em relação à escolarização de filhos de migrantes, ao impacto do pluralismo cultural e linguístico, na educação, à influência do racismo nos resultados escolares» (Rocha Trindade, 1995:257).

Foi nos anos 70 que esta organização internacional começou a dar atenção aos aspectos de desigualdade perante a educação. Nos anos 80 interessou-se pela situação das crianças filhas de migrantes numa perspectiva de progresso económico e social.

O Conselho da Europa é um dos organismos supranacional europeu que mais contribuiu para promover e dinamizar as políticas multiculturais educativas dos anos sessenta e setenta, e é também o principal impulsionador e definidor da educação intercultural. Este organismo promoveu o ensino da língua e da cultura de origem dos filhos de imigrantes, desde os anos sessenta, e mais tarde fomentou experiências de educação intercultural (a partir de meados dos anos oitenta). Este Conselho afirma que a presença de crianças de diferentes origens na escola representa uma riqueza, referindo as potencialidades do multiculturalismo como factor de enriquecimento, como instrumento para promover a igualdade de oportunidades e a inserção das minorias.

Assim, as linhas programáticas do Conselho da Europa podem-se resumir aos seguintes pontos: 
«- as sociedades tornaram-se multiculturais - cada cultura tem as suas especificidades próprias, que se devem respeitar em si mesmas;

- não se trata de promover uma mestiçagem cultural mas de promover a comunicação e a aceitação do outro» (Ferreira, 2003:77).

Relativamente à posição da União Europeia, podemos declarar que as instâncias comunitárias se dedicam à questão da educação intercultural desde os anos setenta, «produzindo estudos especializados, redigindo normas orientadoras e promovendo acções de vária natureza, que têm por objectivo proporcionar igualdade de oportunidades no acesso ao ensino e no alcance de sucesso educativo em contextos multiculturais» (Rocha - Trindade, 1995:259). Estão nesse âmbito programas específicos como o Erasmus, Comett e o Língua que promoveram o espírito europeu e a dimensão intercultural da educação na Europa, com o intercâmbio de estudantes e professores. Promoveu também a aprendizagem de línguas faladas no espaço comunitário, a realização de visitas de estudo e o desenvolvimento de projectos de investigação - acção através do programa Sócrates.

Estas iniciativas são desenvolvidas tendo em vista a construção da Europa Social e de uma cidadania europeia baseada no reconhecimento, na aceitação da diferença e na interacção das diferentes culturas.

\subsection{A educação intercultural}

A partir dos anos 60, o fenómeno multicultural tem sido tratado, numa perspectiva de resposta multidimensional, a partir de quatro posturas ideológicas: assimilacionista, integracionista, pluralista e interculturalista.

Na postura assimilacionista, a diversidade e a diferença são percebidas como ameaças à coesão da sociedade de acolhimento, cuja cultura é considerada como dominante e dominadora. A postura integracionista declara a igualdade de direitos para todos os cidadãos, promovendo a unidade através da diversidade. A postura pluralista respeita a diferença cultural e entende-a como uma valência positiva, afirmando que para além do direito à diferença cada grupo deve conservar e desenvolver as suas características culturais, no contexto da sociedade de acolhimento. 
De todas destacamos a postura interculturalista que possibilita aceitar e valorizar a diferença e defende a comunicação, a afirmação e o diálogo multiculturais. Promove a relação dinâmica entre as culturas, ou seja, valoriza a diferença e esforça-se por encontrar pontos comuns entre pessoas e culturas. Trata-se da construção de uma sociedade aberta, que apesar de consciente do choque de culturas encontra-se receptiva ao exercício de crítica e da postura ética, na defesa de princípios e valores humanos que respeitem a alteridade. Como nos diz Abdallah-Pretceille (1986:177), o intercultural é antes de mais, e antes de tudo, uma prática e «acaba por ser uma opção sociológica global».

O conceito de intercultural implica reciprocidade e partilha na aprendizagem, na comunicação e nas relações humanas. 0 intercultural não é um conceito exclusivo do domínio pedagógico. Numa perspectiva sociológica mais global, o interculturalismo é uma atitude humanista que deseja o diálogo, o respeito pelas diferenças e a compreensão mútua. Numa perspectiva educacional, o interculturalismo baseia-se sobretudo nos processos educativos reflexivamente concebidos, promotores de pluralismo e da igualdade de oportunidades educativas e sociais.

Tendo em conta que nas escolas se evidencia uma crescente diversidade sócio-cultural, a que é necessário dar resposta, o Ministério da Educação reconhece a necessidade de promoção da educação intercultural. Assim, e de acordo com recentes orientações do Ministério da Educação, a educação intercultural é uma nova perspectiva educativa vocacionada para:

- «um melhor acolhimento aos alunos de origem estrangeira ou aos nacionais de vivências socioculturais diferentes;

- facultar o ensino da língua oficial (Português) como Língua Não Materna, assumindo-a como uma língua viva, aberta a interferências;

- accionar processos que ajam directamente em benefício da auto-estima, da auto-imagem e da auto-confiança dos 'diferentes';

- a partilha de conhecimentos, valores, expressões estéticas, técnicas, cultos de cada cultura, incentivando a reflexão sobre as diversidades, as dimensões comuns, as riquezas e os preconceitos patentes;

- a abordagem, por parte das escolas, dos conteúdos educativos na perspectiva de transmitir a variedade de herança multicultural em si presente, ajudando os jovens cidadãos a crescer na 
interdependência, na solidariedade, na mediação, na tolerância activa» (Departamento de Educação Básica, 2000:7).

Para Américo Peres (1999:67) a «educação intercultural apresenta-se como um projecto educativo que valoriza a diversidade sócio-cultural, ao mesmo tempo que aposta na reanimação da cultura: encontro, relação, convivência, festa, alegria, fantasia e comunicação». É um «projecto em construção, uma força dinamizadora da vida que, partindo do topos cultural, permitirá um caminho mais humanizante para as mulheres e para os homens» (ibidem). É ainda um projecto interpessoal que integra a ética e o conhecimento, ao mesmo tempo que cria condições para o desenvolvimento da comunidade local e global. Este autor acrescenta que se trata de uma viagem em direcção ao outro, de forma a tornar a sociedade mais justa e democrática.

De acordo com Ricardo Vieira (1995:143), «o modelo intercultural implica uma dialéctica em constante contradição: assegurar a diferença e simultaneamente não a sustentar. (..) 0 interculturalismo implica não somente reconhecer as diferenças, não somente aceitá-las, mas - e o que é mais difícil - fazer com que elas sejam a origem de uma dinâmica de criações novas, de inovação, de enriquecimentos recíprocos e não de fechamentos e de obstáculos ao enriquecimento pela troca».

A educação intercultural deve contribuir para ultrapassar o etnocentrismo sociocultural, tendo em consideração na pedagogia global, as situações multilingues e pluriculturais, proporcionando um melhor desempenho escolar aos filhos de trabalhadores imigrantes (sobretudo de meios desfavorecidos), correspondendo às suas necessidades específicas. Levar os jovens a conhecer e conviver com a diferença, valorizar capacidades específicas e talentos diversificados, sem requerer de todos exactamente - mesmo, preparar para desempenhos múltiplos, gerir a resolução de problemas e de conflitos, ressalvando valores consensuais das diferentes culturas e promover o conhecimento mútuo, a estima responsável e a cordialidade cívica, são os principais objectivos da educação intercultural.

Para que estes objectivos tenham resultados a nível das metodologias deverão ser elaborados projectos de turma, com adequada gestão de currículo, criados trabalhos de projecto, com parcerias nacionais e/ou internacionais, dinamizados círculos de formação em contexto profissional e realizados projectos de investigação - acção.

A formação de professores, pertencentes a todos os níveis de ensino, é também muito importante e por esse motivo muitas instituições incluem 
já no seu currículo de formação inicial, disciplinas onde é abordada a problemática da educação intercultural. Esta questão será abordada de uma forma mais aprofundada no ponto 4.5.

\subsection{A educação intercultural como facilitadora da integração}

Em educação é necessário promover a relação dinâmica entre as culturas, valorizar as culturas nas suas diferenças (no respeito pelas diversas identidades) e nas suas dimensões comuns de forma a reforçar um sentido de comunidade humana e evitar práticas pedagógicas discriminatórias.

A reflexão sobre a diversidade cultural e a descentração dos valores da sua própria cultura para conseguir olhar a sociedade na perspectiva das minorias, são atitudes do professor, indispensáveis para organizar e estruturar as actividades escolares no sentido de promover uma igualdade de oportunidades. Para isso é necessário conhecer e valorizar as características das culturas das minorias e ter em atenção que os alunos, quando entram na escola, já são portadores dos fundamentos de uma identidade cultural adquiridos durante a socialização primária, na família e na comunidade de origem.

No entanto, devido à tradicional inadequação da organização da escola face à diversidade e certas especificações da cultura dos professores ainda se considera que idealmente o grupo - classe «normal» deve ser definido em função das características da cultura portuguesa, obedecendo a um perfil de criança falante da língua portuguesa, católico, da classe média. Neste contexto, o professor «monocultural» (Cortesão e Stoer, 1995; Stoer e Cortesão, 1999) vê a diversidade como um obstáculo à tarefa de ensinar.

Assim, na nossa realidade escolar, cada vez mais plural a nível cultural, mais multicultural, encontramo-nos perante a questão de como lidar com diferentes culturas e perante o problema de comunicação entre «diferentes». É necessária uma transformação da educação escolar, de modo a quebrar o seu tradicionalismo e a abranger na sua cultura outras subculturas tendo em conta as realidades locais e mundiais. No caso desta transformação não se verificar a educação escolar está, na opinião de Carlinda Leite (2002:97) «sujeita, pelo menos, a duas situações:

1) perder uma das razões da sua existência, e que é a de contribuir para uma educação para todos; 
2) ser um veículo de marginalização de certos grupos sociais ou obrigá-los a um processo de assimilação, sujeitando-os a uma perda das suas identidades culturais».

Porém, e secundando Leite (2002:145), «há que não pensar a educação intercultural como uma panaceia que resolve todas as situações de desigualdade, discriminação e exclusão económica, social e cultural». Ainda segundo esta autora a relação intercultural é um processo que permite a aquisição de um bilinguismo cultural «que facilita o acesso de crianças e jovens de grupos minoritários não apenas ao conhecimento das suas culturas de origem, mas também ao conhecimento de outras culturas e ao usufruto dos bens por elas proporcionadas no exercício da cidadania» (ibidem). Deste modo, o desenvolvimento deste bilinguismo cultural, também referido por Stoer e Cortesão (1999), entendido como o domínio da cultura de origem e simultaneamente domínio da cultura de estatuto social mais reconhecido, possibilita desenvolver atitudes de alteridade e de respeito pelo outro e permite ainda uma maior consciência da importância e do direito à saúde, à educação, à justiça, aos serviços sociais, a um trabalho condigno e à participação e intervenção social.

Na mesma linha de raciocínio, o conceito de literacia multicultural, criado por Banks e Banks (1989), é uma proposta educativa para a educação multicultural, «uma ferramenta importante, uma nova aquisição básica necessária a qualquer cidadão nas sociedades complexas do mundo moderno» (Souta, 1997:50). Neste conceito, o conhecimento é entendido «como dinâmico, mutável, reflectindo os contextos sociais, políticos e económicos em que é criado» (idem:48). Mais concretamente, e de acordo com este autor, as duas componentes chave da literacia multicultural são «ver o conhecimento como uma construção social e entendê-lo segundo diferentes perspectivas culturais» (ibidem).

A educação intercultural apresenta-se como um projecto educativo que valoriza a diversidade sociocultural e que, simultaneamente aposta na reanimação da cultura através da comunicação, relação, convivência e encontro entre culturas. Esta comunicação intercultural é essencial e uma pedagogia da relação intercultural deve ter como base a compreensão e a tolerância, o reconhecimento do outro e da diversidade. Esta pedagogia possibilita não só a determinação das suas próprias representações, dos modelos do seu sistema de valores, mas também a identificação das representações e dos sistemas de valores e de normas dos outros indivíduos e grupos, constituindo um meio de conhecimento e de aprendizagem do outro e de compreensão intercultural. 
Nesta perspectiva, a educação intercultural é um projecto em construção que permitirá um caminho mais humanizante para o ser humano, um projecto interpessoal que integra a ética e o conhecimento e que crie condições para o desenvolvimento da comunidade local e global.

Para Fernand Ouellet (1991:141-142), a educação intercultural deve ser desenvolvida não só em grupos minoritários mas também em grupos maioritários. Nesta perspectiva, este autor propõe «uma melhor compreensão das culturas nas sociedades modernas; uma maior capacidade de comunicar entre pessoas de culturas diferentes; uma atitude mais adaptada ao contexto da diversidade cultural de uma dada sociedade, devido à melhor compreensão dos mecanismos psico-sociais e aos factores sociopolíticos capazes de produzir o racismo e finalmente, uma melhor capacidade de participar na interacção social, criadora de identidades e de reconhecimento da pertença comum à humanidade».

\subsection{Da educação monocultural à educação multicultural e intercultural}

De acordo com Carlinda Leite (2002:136), «é na institucionalização de um discurso que defende o direito de todos à educação e à igualdade de oportunidades que se enraízam as acções educativas de resposta à multiculturalidade». A resposta escolar à multiculturalidade surge na forma da educação intercultural. No entanto, desde a fase do monoculturalismo, baseado na valorização exclusiva dos produtos da cultura homogénea, até à escolha de práticas pedagógicas de educação intercultural percorreu-se um longo caminho.

Confrontada com a crescente heterogeneidade cultural e linguística dos alunos, a instituição escolar respondeu de diversos modos com o objectivo de promover a integração das crianças imigrantes, e o acesso de todos os alunos a uma escolaridade com sucesso.

Segundo Lipiansky (1999, cit. por Ferreira, 2003:50), a «primeira reacção da escola foi considerar a maior parte das vezes, a diversidade cultural como um obstáculo a eliminar». As diferencas eram consideradas como problemáticas, devendo ser reduzidas ou eliminadas. No entanto, alguns pedagogos defenderam a necessidade de ter em consideração a diferença cultural que devia ser vista «como uma identidade que a escola devia respeitar e sobre a qual se devia mesmo apoiar, pois ela pode ser, para todos os alunos, o ponto de partida para uma reflexão sobre a diversidade de culturas, sobre a tolerância e sobre a forma de lutar contra os preconceitos» (Ferreira, 2003:51). Porém, igualmente esta pedagogia foi 
criticada pois ela poderia implicar um acentuar das diferenças, e sob a justificação do reconhecimento da sua alteridade, estigmatizá-los como diferentes dos outros alunos. Então, uma outra tendência surgiu, acentuando a noção central de cidadania (numa perspectiva liberal), considerando a escola como «um lugar de aprendizagem da igualdade de todos os alunos, quaisquer que sejam as suas origens e religiões» (ibidem). Esta tendência defende que as diferenças tenderão a ser apagadas, rejeita o multiculturalismo e promove a integração de todos, baseada numa cultura comum para todos. Contrariamente, para outros a escola deve reconhecer o valor igual de cada cultura admitindo o relativismo cultural. Assim, a escola deve beneficiar uma abertura dos alunos em relação à variedade de culturas.

Actualmente, e segundo Lipiansky (1999, cit. por Ferreira, 2003:51), a «reflexão sobre a interculturalidade não se pode limitar às crianças migrantes». Segundo este autor, os objectivos de uma prática intercultural alargada na educação poderiam ser: «aprender a reconhecer a diversidade dos códigos culturais, saber comunicar num contexto intercultural, tomar consciência da sua própria identidade cultural, ser capaz de ir para além dos estereótipos e dos preconceitos, conhecer melhor as instituições, as características sociais, as formas de saber viver dos diferentes países europeus (...)» (ibidem).

Consideramos importante salientar que «educação multicultural» e «educação intercultural» têm diferentes significados e são utilizadas com sentidos diferentes por vários autores. Outros autores utilizam ainda a terminologia «educação inter/multicultural, considerando que estes conceitos se complementam e se completam. Em nossa opinião, a multiculturalidade pode ser encarada como manifestando uma perspectiva um pouco estática da constatação da diversidade e da tentativa de explicar situações de desigualdade social por intermédio das diferenças sociais. A interculturalidade, para além de reconhecer as diferenças de poder e o peso da estrutura social, inclui uma vertente interactiva e processual no bom prosseguimento das relações dentro da diversidade, do respeito e valorização mútuas, e da superação das limitações em termos de oportunidades de sucesso que a pertença a uma determinada cultura pode implicar. Deste modo, consideramos que a perspectiva intercultural procura superar e combater fenómenos de dominação cultural, por vezes ocultos ou dissimulados, promovendo a igualdade de direitos de cidadania, de sucesso e de participação activa na sociedade por parte de todas as pessoas. No entanto, julgamos ser pertinente a clarificação destes dois conceitos e para isso apresentamos a opinião de alguns autores que se têm debruçado sobre a temática da educação em contexto de diversidade cultural. 
James Banks emprega a expressão educação multicultural para referir práticas e programas concebidos para contribuírem para um melhor rendimento escolar dos grupos étnicos ou de migrantes e/ou instruir os estudantes dos grupos maioritários sobre as culturas e expressões dos grupos minoritários. Na opinião deste autor, «a educação multicultural é um conceito amplo que engloba, os estudos étnicos, a educação multiétnica e a educação anti-racista. Consiste numa reforma educacional cuja finalidade é modificar o ambiente da escola de tal forma que, diferentes tipos de grupos, incluindo os grupos étnicos, as mulheres e os grupos de alunos com necessidades educativas especiais (como por exemplo, os que têm dificuldades de aprendizagem e os sobredotados) tenham uma educação igual e paridade na escola» (Banks cit. por Ferreira, 2003:117). Para este autor, a educação multicultural é um movimento de reforma da educação que leva à igualdade de oportunidades para todos os alunos, tornando-se necessária uma modificação da totalidade do ambiente na escola de tal maneira que este reflicta as diversas culturas e grupos existentes na sociedade e na própria escola. Este autor acrescenta ainda que um importante objectivo da educação multicultural é a de «ajudar os alunos a desenvolverem o espírito crítico e a adquirirem os conhecimentos, as atitudes, as capacidades e o empenhamento necessários para participarem numa actividade democrática, que contribua para que os ideais da democracia se tornem realidades» (idem:120). Deste modo, a educação multicultural pode ser encarada como uma educação para aplicar de uma forma contínua numa sociedade pluralista e democrática.

São cinco as dimensões que Banks (1995) identifica na educação multicultural:

- «a integração de conteúdos; o processo de construção do conhecimento; a redução de preconceitos; uma pedagogia igualitária; uma cultura da escola e uma estrutura social que suporte o desenvolvimento da educação multicultural» (idem: 123).

Apesar de alguns autores anglo-saxónicos utilizarem a expressão «educação multicultural» para se referirem à abertura à diversidade cultural, ao respeito pelo «outro» e ao desenvolvimento da solidariedade entre diferentes grupos socioculturais, outros autores de origem francófona utilizam a designação «educação multicultural» apenas para se referirem à aceitação passiva da diversidade, recorrendo-se da expressão «educação intercultural» quando querem salientar o intercâmbio, o diálogo e a interacção entre as culturas ou subculturas. 
Assim, para Carmel Camilleri (1999), a expressão multicultural refere-se somente à pluralidade, às situações de coexistência de facto entre as culturas ou subculturas e ao estudo dos efeitos dessa coexistência, reservando a utilização do termo «intercultural» para se referir à preocupação com os obstáculos à comunicação entre os indivíduos detentores das diferentes culturas, analisando-os e tentando fazê-los desaparecer. De acordo com este autor, «a finalidade de uma pedagogia intercultural é a de construir, entre portadores de sistemas culturais diferentes, articulações que permitem evitar ou corrigir as consequências negativas que podem ocorrer devido a essas diferenças» (idem:112).

Também para Clanet (1990), o termo intercultural salienta as noções de reciprocidade nas trocas e de complexidade nas inter-relações entre as culturas. Nesta perspectiva, a educação intercultural visa um diálogo interactivo entre as diferentes culturas com efeitos ao nível do respeito de cada indivíduo pela sua cultura quer pela cultura do «outro».

A dimensão da educação multicultural (designação predominante nos países anglo-saxónicos) diz respeito a «um conjunto de estratégias organizacionais, curriculares e pedagógicas ao nível de sistema, de escola e de classe, cujo objectivo é promover a compreensão e tolerância entre indivíduos de origens étnicas diversas através da mudança de percepção e atitudes com base em programas curriculares que expressem a diversidade de culturas e estilos de vida» (Carrington; Shtort, 1989 cit. por Cardoso, 1996:9). Este autor acrescenta ainda que para que as práticas educativas, em contextos culturalmente heterogéneos, alcancem uma real «igualdade de oportunidades terão que manter indissociáveis as vertentes de antiracismo e de multiculturalidade» (Cardoso, 1996:9). A educação multicultural, encarada como um processo progressivo de mudança, obriga que a escola como um todo, ao nível do seu ambiente, da sua organização administrativa e pedagógica, se estruture de modo a promover a reflexão e a acolher da melhor forma a diversidade dos seus alunos; implica reajustamentos do currículo ao nível dos conteúdos, das estratégias e das interacções entre alunos e professores, de modo a proporcionar a todos os alunos igualdade de circunstâncias educativas; procura realizar os princípios democráticos da justiça social através de pedagogias críticas, proporcionando conhecimentos, desenvolvendo a reflexão-acção que permita aos alunos, futuros cidadãos, participar nas transformações sociais no sentido de atingir níveis cada vez mais elevados de igualdade de oportunidades; rejeita e combate todas as formas de discriminação na escola e na sociedade; aceita e defende o pluralismo representado pelos alunos e pelas suas famílias; requer a dinamização das relações da escola com as famílias, promovendo o diálogo, a participação e a co-responsabilização. 
Para Abdallah-Pretceille, os termos intercultural e pluricultural, representam realidades diferentes. Para este autor, «noções como pluralismo cultural ou multiculturalismo apontam quer para uma constatação de tipo descritivo, quer para uma concepção das relações sociais e culturais fundada sobre uma justaposição de culturas, com todos os impasses daí decorrentes como, por exemplo, uma estratificação ou até mesmo uma hierarquia de grupos» (Abdallah-Pretceille, 1985 cit. por Ferreira, 2003:110). Nesta perspectiva, o termo intercultural demarca-se profundamente das posições pluriculturais ou multiculturais, pois preocupa-se com a função de inter-relação entre modos de sentir e de compreender a realidade, com os seus processos e menos com os conteúdos propriamente ditos. Assim, a grande finalidade da educação intercultural é contribuir para manter a unidade, valorizando as culturas nela presentes, culturas que se vão modificando umas em contacto com as outras.

Stoer e Cortesão (1999) apresentam-nos algumas recomendações, baseadas em McCarthy (1994), a ter em consideração na prática de uma educação inter/multicultural: identificar «constrangimentos e barreiras postas à criatividade dos professores e à inovação da cultura institucional das escolas»; «articular um conjunto de práticas que tenham em consideração diferenças de necessidades, interesses de minorias e da juventude urbana em situação difícil»; implementar «esforços muito maiores na consecução de metas de igualdade de oportunidades de acesso e de sucesso»; desenvolver, em vez de «um currículo constituído por segmentos de informação», um conhecimento escolar que seja «visto como um processo dinâmico e multifacetado», apoiar-se «num modelo multidisciplinar que enfatize a interdisciplinaridade, o desafio intelectual, o debate entre perspectivas antagónicas e um vigoroso questionamento das tradições recebidas», «enfatizar a autonomia dos estudantes relativamente a múltiplas fontes de informação», «estabelecer claras conexões entre saber e poder» (McCarthy, 1994 cit. por Stoer e Cortesão, 1999:30 e 31).

Se a diversidade for vista como uma fonte de riqueza para o aprofundamento da vertente democrática da instituição escolar e do sistema educativo, a educação intercultural faz todo o sentido enquanto resposta ao desafio de um a educação que visa formar cidadãos activos, críticos, conscientes das suas diferenças e portadores da sua identidade cultural. A defesa de uma educação intercultural «decorre de um imperativo demográfico e dos problemas colocados por uma sociedade cada vez mais multicultural, em termos étnicos, linguísticos, religiosos e culturais» (Souta, 1997:44). Neste contexto, a educação intercultural é, actualmente, uma componente essencial na formação das crianças e jovens. 
0 intercultural condiz com um perspectivar de uma nova sociedade, onde

a integração das diferenças surge como uma riqueza cultural. Para Ricardo Vieira (1995:145), «o intercultural corresponde a uma política, a uma pedagogia, a uma atitude, a uma construção a edificar para uma escola mais democrática e para uma sociedade da não uniformização do cidadão como moeda única, por um lado, e para a não reprodução eterna do governo ditatorial dos estratos dominantes sobre os dominados».

\subsection{0 professor intercultural}

Do processo de integração/inclusão dos alunos de diferentes culturas na escola e do papel do professor devemos salientar a grande importância das práticas escolares. Isto implica uma nova filosofia face à diversidade e a redefinição de métodos de ensino.

A situação multicultural exige um conhecimento da sociedade, dos fenómenos migratórios e das realidades de outros meios culturais. Deste modo, é fundamental que os professores se preparem para receber e compreender os seus alunos e respectivas famílias vindos de outros países ou de diferentes regiões do país, que respeitem a diversidade de línguas, comportamentos, religiões e modos de vida, que consigam gerir os conflitos e saibam aproveitá-los para enriquecer culturalmente cada um dos seus alunos e a si próprio. E através de uma visão multicultural que o professor dos nossos dias deve pautar a sua forma de estar na sala, tornando-a num local de aprendizagem não só de conteúdos programáticos, mas também onde podemos ensinar algo aos outros e acima de tudo aprender muito com eles. Para isso, a escola e os docentes têm o dever de valorizar, aceitar e aproveitar saberes, valores, interesses e competências que os alunos trazem, pois eles não entram para a escola como uma «tábua rasa, uma mente vazia» (Perrenoud, 2000:28). Na realidade, as crianças quando entram na escola já possuem conhecimentos, conceitos, informações, experiências vividas e até preconceitos derivados de vários agentes socializadores, tais como, a família, vizinhos e meios de comunicação. Assim, a formação dos docentes em contextos multiculturais é a pedra basilar da educação intercultural, pois conduz à melhoria da qualidade do ensino e das capacidades dos professores face à diversidade.

Na verdade, a educação intercultural é um processo em que se educa mais fazendo e sendo do que dizendo. Nesse processo, estão em jogo a satisfação das necessidades básicas e o desempenho socialmente admitidas como válidas para a dignidade individual e colectiva. Devemos 
aprender a cultivar comportamentos e atitudes solidárias, democráticas e cívicas e promover o reconhecimento da pluralidade e da alteridade. Para isso é necessário o desenvolvimento por parte dos professores de atitudes não etnocêntricas, ser sensível e respeitar as várias diferenças e ter a capacidade de pôr em questão práticas desenvolvidas durante anos em função da cultura dominante e substituí-las por outras que promovam a paridade de culturas e a emancipação dos alunos mais desfavorecidos.

As práticas lectivas devem apelar à cooperação e valorizar diferentes saberes, diferentes aptidões e capacidades. Deve ser promovido o desenvolvimento ético-social para resolver conflitos, mediante uma negociação, uma mediação dos mesmos. Para praticar a educação intercultural é necessário organizar e administrar a escola tendo em conta a diversidade cultural existente, considerando essa diversidade nos planos educativos da escola, nos planos curriculares de turma, discuti-la nas assembleias de escola, nos conselhos de escola e nas assembleias de turmas, de forma a promover a interacção cultural, combatendo todos os estereótipos e formas de discriminação. 0 currículo, de âmbito nacional, deve ser adaptado aos diferentes contextos e à realidade cultural da sala de aula. Ao ensino da Língua Portuguesa como língua não materna deve ser dada uma atenção especial, pois o seu conhecimento condiciona todas as outras aprendizagens. Consideramos que é ainda necessário encarar o curriculum intercultural e inclusivo como aquele que «potencia aprendizagens significativas para todos os alunos numa autêntica circularidade entre conhecimentos, habilidades, atitudes e valores e, ao mesmo tempo, promove interacções positivas e um clima de convivialidade entre os vários grupos culturais e étnicos que fazem parte de uma determinada comunidade educativa» (Peres, 1999:156).

Na opinião de Carlinda Leite (2002:244), «perante a diversidade dos alunos, um professor que desenvolve práticas que contemplem essas especificidades acredita nas vantagens que daí decorrem e transporta para a escola os saberes do quotidiano dos diversos grupos, trabalhando-os, não de forma esporádica e fragmentada, mas contextualizada e vivenciada por processos interagidos». Porém, a formação de professores para a interculturalidade, formação inicial e contínua, é rara. De acordo com Rosa (2002), a formação para a interculturalidade pressupõe uma formação inicial que deve criar estruturas e atitudes formativas de base para depois continuar ao longo da vida de cada professor em cursos, seminários, diariamente na sala de aula, na procura das respostas mais adequadas a cada aluno e a cada situação. Nessa formação inicial de professores é igualmente essencial que os programas «contemplem um curriculum global, integrado e integrador de todas as culturas, que respeite as diver- 
sidades e contribua para a dignidade da pessoa humana como ser original» (Peres, 1999:274).

Dentro da escola é necessário criar pontes - dispositivos pedagógicos, interculturais - que propiciem uma permeabilidade entre valores, saberes e estilos de vida e das culturas maioritárias e minoritárias. Assim, é possível à escola oferecer a possibilidade de sucesso a crianças diferentes das da norma que habitualmente valoriza. Estes dispositivos pedagógicos podem ser definidos como «propostas educativas que visam construir uma 'boa ponte' na ligação necessária entre a cultura da escola e a da comunidade envolvente, comunidade essa representada através da presença dos alunos na instituição. Só será possível construir um destes dispositivos se o professor tiver consciência da diversidade cultural em que trabalha, consciência essa que exige uma atitude e práticas investigativas necessárias à identificação e compreensão do 'arco-íris cultural' ao qual tem de oferecer propostas educativas adequadas» (Stoer e Cortesão, 1999:60).

O professor, ao aderir a práticas de educação intercultural, tem subjacente o desenvolvimento de determinados conhecimentos, atitudes e competências. De acordo com Cardoso (1996:33), o professor terá que desenvolver progressivamente:

«- conhecimento das principais características culturais das minorias étnicas e da sua situação desfavorecida na sociedade;

- disponibilidade/convicção para aderir ao projecto de consolidação de um clima de educação multicultural e anti-racista na escola;

- atitudes: al de reflexão acerca do modo como percepciona a situação das minorias na sociedade e na escola; bl de consciencialização dos seus próprios sentimentos e atitudes em relação aos alunos pertencentes a minorias; c) de questionamento acerca das próprias práticas pedagógicas em classes/turmas étnica e socialmente heterogéneas; d) de análise e avaliação do nível de (in)adequação do ambiente global da escola face à diversidade dos alunos que a frequentam;

- atitudes positivas em relação aos pais/famílias dos alunos pertencentes a minorias, começando pela abertura e interesse em ouvir e considerar os seus pontos de vista;

- capacidade de olhar para a sociedade na perspectiva das minorias étnicas; 
- expectativas positivas e adequadas a todos e cada um dos seus alunos, afastando o efeito de preconceitos e estereótipos;

- competências para proporcionar a todos os alunos igualdade de oportunidades no acesso aos conhecimentos e competências relativas às diferentes disciplinas do currículo».

Como temos vindo a salientar ao longo deste trabalho, a problemática da integração das crianças pertencentes a grupos minoritários (migrantes, minorias linguísticas, étnicas, culturais, grupos desfavorecidos ou marginais) é complexa. Num contexto de globalização de mobilidade das populações, devemos conceber o sistema educativo como um importante instrumento para promover a igualdade educativa para todos e a escola como - local privilegiado para reorientar as práticas de socialização e humanização na direcção da educação intercultural e da educação para a cidadania.

Porém, apesar das normas e recomendações das organizações internacionais que têm vindo a influenciar as políticas educativas no nosso país, no sentido de criar estruturas educativas e sociais que promovam acções concretas com o objectivo da integração de todas as crianças na escola e sociedade, verifica-se que há um caminho a percorrer a nível da concretização das políticas, a nível da estrutura organizativa da instituição escolar e a nível da formação de professores. Relativamente à formação de professores numa perspectiva intercultural, é frequente que a formação para a diversidade tenha resultados pouco significativos pois implica uma mudança de atitudes face ao outro diferente, alterar formas de agir e de trabalhar e a determinação das causas dessas formas de agir e de pensar. A formação para a diversidade, de um modo geral, resume-se à «aquisição de conhecimentos sobre as culturas, a evidenciar e às vezes até confraternizar com alguns costumes e valores, geralmente numa perspectiva da sua folclorização» (Cortesão, 2000: 16), mas poucas vezes se discute problemas reais de poder que estruturam relações entre grupos e questões de compatibilização de racionalidades. É úrgente desenvolver programas de formação e desenvolvimento profissional dos professores significativos e de qualidade e de todos os serviços de apoio envolvidos de modo a criar na escola uma nova cultura organizativa a nível social e pedagógico - didáctico para que todos os grupos - minoritários e maioritários - aprendam a viver juntos numa verdadeira permeabilidade de pessoas e culturas e sem separação entre o «nós» e os «outros». Só assim, é que a escola pode suscitar verdadeiras aprendizagens interculturais, que permitam às crianças dos grupos minoritários a aquisição de competências que lhes possibilitem uma participação activa e criativa na comunidade maioritária, preservando simultaneamente as suas identidades culturais. 
Cortesão e Stoer (1995 e 1999) defendem a formação do professor inter/multicultural como agente promotor de uma democracia aprofundada, indicando no seguinte quadro as suas principais características e os seus pressupostos estruturantes.

\section{Quadro VII - Características do professor inter/multicultural}

\section{0 (A) Professor(a) Inter/Multicultural}

1. Encara a diversidade cultural como fonte de riqueza para o processo de ensino/aprendizagem;

2. Promove a rentabilização de saberes e de culturas;

3. Toma em conta a diversidade cultural na sala de aula tornando-a condição de confrontação entre culturas;

4. Refaz o mapa da sua identidade cultural para ultrapassar o etnocentrismo cultural;

5. Defende a descentração da escola - a escola assume-se como parte da comunidade local;

6. Conhece diferenças culturais através do desenvolvimento de dispositivos pedagógicos na base da noção de cultura como prática social.

Pressupostos estruturantes:

- Cidadania baseada na democracia participativa

- Igualdade de oportunidades - sucesso

- Escola Democrática

In: Cortesão e Stoer (1995:44); Stoer e Cortesão (1999: 47)

0 professor inter/multicultural, atento às questões da diversidade será um elemento facilitador no âmbito da compreensão e identificação do «arco-íris cultural» presente na sala e na escola. Esta postura tem como base a construção de comunidades culturais que se reconhecem, respeitam e interagem. É uma proposta intercultural que não se confunde com a justaposição de culturas nem o atropelo de umas sobre as outras, mas antes assentando na liberdade conquistada de ser diferente sem medo de o ser, crescendo juntos sem tensão, atravessando todos a mesma ponte. 
Para que isto aconteça, as práticas pedagógicas dos professores e currículos devem orientar-se no sentido da solidariedade e justiça social. Desta forma, secundamos Cortesão e Stoer (1995:43) quando afirmam que «o professor inter/multicultural configura-se assim, como um dispositivo de aprofundamento do espaço democrático da Escola para todos».

\subsection{A educação intercultural e a educação para a cidadania}

De acordo com Cardoso (1998:100), «não há educação para a cidadania que não seja educação intercultural». Esta visa, não só, estimular a inter-relação, a compreensão e o respeito entre os alunos de variadas origens étnicas, raciais, culturais, religiosas e socioeconómicas mas, principalmente, prepara futuros cidadãos interessados na promoção da justiça social e na eliminação da exclusão em todas as suas formas. A sua intenção é a de contribuir para a concretização da plena igualdade de oportunidades na sociedade, iniciando-a no domínio da educação. Para este autor, «a educação para a cidadania, assim como a sua dimensão intercultural, passam sobretudo pelo desenvolvimento e interiorização, em liberdade de consciência, de atitudes e valores democráticos. Estas aprendizagens são promovidas, principalmente, através da forma como é organizado o processo educativo, do papel que nele é reservado aos alunos e das experiências que thes são proporcionadas. Os conteúdos, intencionais e criteriosamente seleccionados, devem suscitar aprendizagens dinâmicas promotoras de valores e atitudes essenciais para o exercício futuro de cidadanias em contextos cada vez mais interculturais» (ibidem).

Segundo Fernand Ouellet (2002), a educação intercultural articula-se inevitavelmente com a educação para a cidadania e as iniciativas que promove correspondem a cinco preocupações ou valores: coesão social (procura de uma pertença colectiva); aceitação da diversidade cultural; igualdade de oportunidades e equidade; participação na vida democrática; preocupação ecológica.

Podemos, então, afirmar que a educação cívica e a educação intercultural estão intimamente relacionadas e apoiam-se mutuamente, ao considerar que a educação intercultural é a resposta pedagógica à exigência actual de preparar futuros cidadãos, tendo em vista o seu desenvolvimento, numa sociedade pluralista e culturalmente diversificada.

A educação intercultural em contextos interculturais é defendida por Teresa Ambrósio ao considerar que esta é «uma boa perspectiva de abordagem da educação para a cidadania» (CNE, 2000:23). Porém, a autora 
pensa que a tolerância é uma atitude actualmente insuficiente porque pressupõe que os centros de poder são imutáveis e as estruturas sociais são permanentes. Neste sentido, a educação intercultural ultrapassa a simples convivência pacífica entre culturas, típica de «comportamentos cívicos e democráticos» (idem:24) e «pede o reconhecimento (...) da multiculturalidade, o que pressupõe partir do conhecimento da diversidade cultural e do reconhecimento de que na diversidade há riquezas potenciais para, a partir delas, criar algo colectivamente novo», isto é, «viver em multiculturalidade exercendo a cidadania» (idem:25). Este reconhecimento da multiculturalidade implica reciprocidade, e implica, desde logo, um conhecimento de culturas diferentes e uma nova forma de as valorizar assumindo os conflitos que provêm dessas diferenças. Trata-se de não apenas sobreviver em tolerância uns com os outros mas de viver diversamente com maior qualidade de relação, enfrentando e resolvendo conflitos reais com justiça e solidariedade. Também Luíza Cortesão (2000:25) considera que as atitudes de tolerância passiva «não coexistem com uma análise relativa a questões de poderes que estão em jogo, não procuram identificar o seu significado no contexto social em que ocorrem, nem se apoiam na consciência de que há fenómenos de discriminação ocultos, mesmo em algumas relações mais bem intencionadas, mais benevolentes».

É neste contexto que surgem propostas de uma educação inter/multicultural crítica que tentam dar às subjectividades e às diferenças culturais o direito a um lugar na escola e deste modo construir uma cidadania fundamentada na democracia participativa. Esta cidadania participativa constrói-se «através da inclusão da diferença e não pela sua exclusão» (Stoer e Cortesão, 1999:49). Isto porque o mero reconhecimento da existência de diferentes culturas não é considerado suficiente por alguns autores, assim como uma postura paternalista e por isso dominadora perante o outro diferente.

Esta proposta está atenta à contextualização social e política em que a educação inter/multicultural surge, ao diálogo entre culturas e à real participação democrática de todas as pessoas, a qual deve iniciar-se na escola, através da sua gestão participada. Assim, Stoer e Cortesão (1999:49) consideram que «a educação inter/multicultural democrática e crítica depende (...) da capacidade dos educadores e professores - de todos os sectores do sistema educativo - de se apropriarem do (...) espaco democrático de cidadania proporcionado pela escola. Este espaço é resultado do facto de a escola ser actualmente oficial, e por isso, obrigatória, laica e gratuita, onde é necessária a produção de um conhecimento profundo das culturas que se estão nele presentes. A concretização da 
igualdade de sucesso para todos na escola dependerá «de uma confrontação cultural dentro da escola de massas», que "só pode realizar-se valorizando dentro da escola as culturas da comunidade local» (idem). Na mesma linha de raciocínio, os autores refutam o chamado multiculturalismo benigno, também referido por Luíza Cortesão (2000:25) que é o que, «com mais frequência informa as propostas de actuação em relação com o outro diferente», o qual é visto de forma benevolente e considera que as suas características como susceptíveis de serem aceitas.

De acordo com Peres (1999: 75), «(re)inventar a educação, atribuindo-lhe uma série de baptismos (...) e, igualmente, referindo de uma forma explícita o seu carácter processual, dinâmico, perfectível, integrador e adaptado aos novos cenários e novos tempos, tem sido uma das ideologias modernistas mais prometedoras de um futuro melhor para todos». Assim, este autor indica-nos modelos e perspectivas que considera afins da educação inter/multicultural: educação para os valores, educação para os direitos humanos e igualdade de oportunidades, educação para a paz, educação para a tolerância e convivência, educação ambiental, educação para a solidariedade e educação anti-racista. 


\section{CAPÍTULO II - A CIDADANIA: UMA PROBLEMÁTICA DA ACTUALIDADE}

\section{NOTAS INTRODUTÓRIAS}

A ideia de cidadania tem vindo a banalizar-se nos últimos anos. Nos variados discursos políticos, sociais e educacionais, a questão da cidadania está cada vez mais presente, sendo amplamente debatida na actualidade o papel e a responsabilidade da educação na promoção, construção e desenvolvimento de uma consciência e cultura cívica. Como sabemos, a instituição escolar nas sociedades ocidentais, ao longo do seu desenvolvimento e transformações, tem veiculado sucessivas concepções sociais, explícitas e implícitas, sobre a cidadania, entendida enquanto modo de interligar o todo social, relacionar-se com os outros e adquirir competências participativas e de intervenção social, numa dada sociedade. Deste modo, à escola, até pela sua própria natureza institucional, sempre foram atribuídas funções de educação para a cidadania e esse conceito tão abrangente tem-se tornado indissociável da própria natureza social da instituição escolar. Através da educação, da instrução e do acesso à cultura letrada, da organização e da hierarquização de funções, da interiorização de valores e através de outras variadas formas, a escola tem vindo a formar as crianças e jovens para a sua inserção na sociedade. Ao longo deste capítulo, tentaremos abordar diversos conceitos de educação para a cidadania, de acordo com diferentes autores, as alterações produzidas pela reorganização curricular, a questão dos valores e o papel do professor na prática e desenvolvimento da educação para a cidadania.

Dado que existem muitas tipologias e classificações de cidadania parece-nos fundamental mostrar essas diferentes concepções que coexistem nas análises contemporâneas. Por outro lado, o significado do conceito de cidadania é multifacetado e pluridimensional pois o seu conteúdo é variável entre culturas, regimes políticos e ao nível do significado linguístico que cada língua the atribui. Deste modo, ao referir concepções de cidadania é necessário ter em atenção o contexto espácio-temporal a que se faz referência dado que os pressupostos teóricos que baseiam uma determinada concepção se inter-relacionam com esse mesmo contexto.

\section{CONCEPÇÕES DE CIDADANIA}

O conceito de cidadania é um conceito problemático, ambíguo, contestado e interpretado de diferentes formas com diferentes implicações normativas. Existem diferentes abordagens à concepção de cidadania que se inserem em três paradigmas distintos: comunitário, republicano e liberal. 
$\mathrm{Na}$ abordagem comunitária da cidadania, a cidadania implica a participação social e o serviço comunitário para o bem geral. Esta concepção funda-se na noção que ser cidadão significa pertencer a uma comunidade histórica. A individualidade de cada cidadão é construída e desenvolvida em termos dessa comunidade cultural e ética. Nesta concepção, a forma de manter a ordem e a coesão social implica a participação de todas as pessoas da comunidade num conjunto de actividades comunitárias de cidadania, com base numa perspectiva social e moral comum. Deste modo, para exercer a cidadania é fundamental assumir responsabilidade por problemas e assuntos que afectam outros cidadãos e manter as tradições que unem os indivíduos e os fazem sentir mais apoiados e inseridos. Apesar de podermos considerar esta perspectiva determinista, na medida em que considera o indivíduo como socialmente determinado pela comunidade, é de salientar o interesse numa participação cívica para o bem público. No entanto, apesar do seu valor relativamente à importância atribuída à responsabilidade pela intervenção comunitária, esta tem sido frequentemente assumida por grupos sociais que aspiram um retorno a valores conservadores, ao mesmo tempo que, numa lógica de maioria, acabam por impor formas de dominação que minimizam as diferenças.

A abordagem republicana de cidadania constitui uma dimensão da perspectiva comunitária. Uma única comunidade, nomeadamente uma comunidade pública desempenha o papel fundamental nas questões de cidadania. Para os republicanos, a cidadania é definida como responsabilidade cívica e participação activa de todos os cidadãos na vida pública, ou seja, participação dos cidadãos nas tomadas de decisão, no valor da vida e debates públicos, defendendo a realização pessoal através da actividade política.

A abordagem liberal de cidadania lidentificada por alguns como socioliberal) tem sido a concepção dominante na maioria das democracias ocidentais desde a segunda guerra mundial. Nesta tradição, a cidadania está relacionada com interpretações relativamente limitadas, formais e legais. 0 termo implica o facto de se terem direitos (liberdade de expressão, de voto ou benefícios sociais) bem como obrigações legais (pagar impostos ou servir as forças armadas). Esta abordagem defende uma concepção de cidadania como um direito social e como um estatuto de igualdade, a cidadania tem um estatuto universal e igualitário, ou seja, todas as pessoas de um mesmo estado são consideradas cidadãos iguais porque têm os mesmos direitos (civis, políticos e sociais) e deveres. A ideia central é que uma vez cidadãos com os mesmos direitos, oportunidades e liberdades os indivíduos são livres de atingir ou de viver diferentes concepções do bem. Assim, os indivíduos devem ter toda a liberdade possível para 
exercer os seus direitos e desenvolver as suas competências individuais, sob o mínimo de interferência possível do Estado e dos seus concidadãos. A cidadania liberal inspira-se nas leis do Estado e implica um código moral limitado que representa a moralidade da justiça e da equidade, assumindo que na esfera pública e da justiça todos devem ser tratados da mesma maneira. Enquanto na esfera pública, as regras a cumprir têm como base a tolerância, o respeito mútuo, a não interferência na vida das outras pessoas ou a negação de imposição de formas de opinião e de acção; na esfera privada pode agir-se livremente, com base em códigos pessoais de justiça ou de moralidade.

A concepção neoliberal, uma corrente mais recente de cidadania, assume a cidadania como sendo um estatuto legal. Os seus simpatizantes enfatizam a liberdade e autonomia individual e tentam enfraquecer a importância do domínio e da prática política, contrariam a existência de Estados-Providência e defendem o mercado livre. Esta concepção encara os cidadãos como consumidores de bens públicos, acreditando que o interesse pessoal é a principal motivação para a acção. Para alguns autores, esta corrente não chega a representar uma verdadeira concepção de cidadania porque consideram que o próprio conceito de cidadania fica sem significado.

\section{A CIDADANIA AO LONGO DOS TEMPOS: BREVE ANÁLISE}

A cidadania é tão antiga como as comunidades sedentárias, definindo os indivíduos que pertencem ou não a uma sociedade comum. Assim, «a cidadania pode ser descrita como participação numa comunidade ou como qualidade de membro dela» (Barbalet, 1989:12).

De um modo geral, o conceito de cidadania diz respeito à qualidade do cidadão, isto é, «do indivíduo pertencente a um estado livre, no gozo dos seus direitos civis e políticos e sujeito a todas as obrigações inerentes a essa condição. Assim, a cidadania é o vínculo jurídico-político que, traduzindo a relação entre um indivíduo e um estado, o constitui perante esse estado num conjunto de direitos e obrigações» (Figueiredo, 1999:34).

Esta temática encontra-se já patente na Grécia antiga, onde a prática da cidadania teve a sua primeira expressão. O termo cidadão (habitante da cidade) traduz um conceito grego, político, habitante da polis, a cidade-estado. Na Grécia, político era adulto livre, pertencente a uma cidade-estado, participante activo nas actividades públicas, detentor de direitos e deveres. De fora ficavam as mulheres, os estrangeiros (metecos) e os 
escravos. Assim, e como salienta Praia (1990: 10), «a concepção grega de cidadania fazia a distinção entre cidadão e o súbdito, considerando-os desiguais e dando primazia ao cidadão - homem, reservando à cidadania direitos como o da participação na vida da cidade, a possibilidade de ser eleito para cargos públicos, e excluindo do direito de cidadania as mulheres, os escravos e os estrangeiros». Para Aristóteles, autor da democracia ateniense, o elemento central da cidadania era a participação na comunidade política, que para além de ser a essência da liberdade, dependia também dela o desenvolvimento e a promoção pessoal dos indivíduos como pessoas. Assim, a prática da cidadania tinha já um significado profundo dado que representava o elemento central ligado ao significado do ser da pessoa humana. Foi na Grécia clássica que, com os Sofistas, pela primeira vez se criou um currículo composto por um conjunto de saberes e competências (a Padeia), com o objectivo de educar os jovens para a cidadania.

Na Roma antiga, o cidadão romano gozava de privilégios, que lhe eram atribuídos por estatuto legal. Para os romanos, a cidadania significava a aceitação da sua soberania cultural e política e aqueles que aceitavam submeter-se ao regime tornavam-se cidadãos. No entanto, na sociedade romana os homens que nasciam livres estavam separados de forma radical dos escravos. Havia também uma profunda diferença entre homens livres que eram cidadãos romanos e os homens livres que não eram.

O termo cidadania ressurge na transição para a modernidade após a Revolução Americana (1774/76) e com a Revolução Francesa (1789). Em 1776, o Congresso de Filadélfia promulga as palavras com que inicia a Declaração de Independência da América referindo que todos os homens foram criados iguais, têm direitos inalcançáveis, nomeadamente a vida, a liberdade e a busca de felicidade. Após esta declaração americana, a explicitação dos direitos do homem terá como referência o valor de um regime político específico - a democracia.

A moderna concepção de cidadania liberal assenta na igualdade de todos os Homens perante a lei. Esta concepção de cidadania remonta à Revolucão Francesa (1789) num contexto novo de democracia. As transformações sociais resultantes dessa fase histórica permitiram a elaboração da Declaração Universal dos Direitos do Homem e do Cidadão, proclamada na Assembleia Nacional Francesa em 26 de Agosto de 1789. Nessa declaração salienta-se que todos os cidadãos são iguais perante a lei e a todos são admissíveis «as dignidades, lugares e empregos públicos, segundo a sua capacidade e sem outra distinção senão a das virtudes e do seu talento» (Declaração dos Direitos do Homem e do Cidadão in Praia, 
1999:10). Essa declaração contém princípios actuais, como por exemplo, a separação dos poderes legislativo e executivo do Estado e a distinção entre estes e o poder judicial.

Está inerente a esta concepção de cidadania a ideia de que o homem tem direitos e deveres perante o Estado. Porém, na prática trata-se duma cidadania reservada essencialmente à burguesia pois baseia-se em direitos cívicos (de liberdade de expressão, de propriedade e de livre opinião), que, na realidade, na época liberal, não são extensivos a todo o cidadão.

Assim, podemos considerar a Revolução Francesa como um período áureo que evidenciou o valor da cidadania, não só pela sua importância em França, mas também pelas forças da reacção desencadeadas com consequências para a população em geral, pelo surgimento de uma concepção universalista de cidadania. O conceito de cidadania desde a Revolução Francesa e dos Direitos do Homem e do Cidadão está relacionada com os conceitos de liberdade, igualdade e fraternidade.

Ao longo do século XIX, o conceito de cidadania fortalece-se no decorrer das lutas dos impérios que caem e das nações que vão surgindo, no entanto este século é duvidoso no que diz respeito à aplicação da filosofia humanista na base da Declaração dos Direitos do Homem e do Cidadão.

Após a 2. a Guerra Mundial no século XX (1939/45), a necessidade de descobrir valores orientadores de acção colectiva dos Estados e dos indivíduos, motivou a criação de uma nova declaração de princípios: a Declaração Universal dos Direitos Humanos, em 1948. Esta declaração que é também um exemplo da concepção actual da universalidade da cidadania, atribui ao ser humano um estatuto próprio que ultrapassa fronteiras na comunidade internacional. Assim, a Declaração constitui um estatuto comum de cidadania mundial independentemente da nacionalidade, idade, sexo, estado, convicção religiosa, política, étnica ou filosófica da pessoa. No entanto, a Declaração Universal dos Direitos Humanos limita-se a decretar direitos sendo um pouco abstracta e imprecisa no que diz respeito à questão da aplicação e cumprimento desses mesmos direitos.

Na linha da tradição liberal, podemos considerar a cidadania como produto de processos sociais diferentes que evoluíram ao longo dos tempos com intervenções de variados grupos sociais.

Numa primeira fase do seu desenvolvimento, o princípio da cidadania resumiu-se à cidadania civil, seguiram-se os direitos políticos, de universalização mais difícil, que se traduziram nos sistemas eleitorais e políti- 
cos, residindo o seu exercício exclusivamente no voto, ficando a representação democrática assente «na distância, na diferenciação e mesmo na opacidade entre representante e representado» (Santos, 1994:205). Apenas numa fase mais tardia, já no século XX, surgiram os direitos sociais como consequência das lutas das classes trabalhadoras.

\section{CONCEITO DE CIDADANIA: CONTRIBUTOS PARA A SUA COMPREENSÃO}

Barbalet (1989) faz referência aos contributos de T. H. Marshall considerando a sua percepção geral de cidadania bastante convencional. Marshall entende a cidadania como «um status adstrito à condição de pleno membro de uma comunidade (...) e quem possuir esse status goza de igualdade no que respeita aos direitos e deveres que the estão associados» (Barbalet, 1989:18). Deste modo, a cidadania explicitada por Marshall ganhou um princípio de igualdade na medida em que o autor se focalizou na atribuição de direitos e deveres comuns a toda a população pertencente a um Estado-Nação, uniformizando-os e generalizando-os. Nesta perspectiva, terminava a predominância de certos grupos sociais sobre outros, funcionando a cidadania como um mecanismo de integração social. «Os argumentos de Marshall sobre cidadania baseiam-se na corrente de democratização da sociedade, que ilustra um princípio central do lluminismo» (Torres, 2001:22).

Se por um lado a perspectiva de aquisição dos direitos de cidadania enunciada por Marshall (1950), na qual defende a seguinte progressão jurídica: no século XVIII foram-se efectivando os direitos civis, no século XIX os direitos políticos e no século XX os direitos sociais, poderá ser criticada por expor uma visão ocidentalizada e linear da história, por outro lado evidencia a progressiva aquisição de direitos de cidadania, considerando que a cidadania e uma conquista, que atravessa os séculos e a própria história humana.

Marshall apresenta-nos uma nova caracterização de cidadania que se presta a uma nova análise das relações entre cidadania e sociedade, análise ausente noutras formas de abordar o tema. Este autor introduziu a noção de cidadania social, no sentido de que, nos Estados Providência da Europa Ocidental, os cidadãos deveriam ter como adquiridos direitos de segurança económica e social. Esta cidadania social seria, para Marshall, o estádio final do conceito, e cabia ao Estado proporcionar aos cidadãos um mínimo bem-estar material para que eles pudessem exercer os seus direitos de participação civil e política na sociedade. 
Deste modo, «é ultrapassando a ideia convencional de que a qualidade de membro de uma comunidade é predominantemente uma questão política que Marshall pode contribuir para o estudo da cidadania» (Barbalet, 1989:18). São identificados por Marshall três elementos da cidadania distintos, que podem estar ou não presentes em qualquer constituição de cidadania: direitos civis, direitos políticos e direitos sociais.

O elemento civil da cidadania é constituído pelos «direitos necessários à liberdade individual, tais como, a liberdade da pessoa, a liberdade de expressão, pensamento e fé, o direito à propriedade e o direito à justiça. A instituição que lhe está associada mais directamente é a letra da lei e o sistema judicial.

A parte política da cidadania consiste no direito de participar no exercício do poder político. Historicamente, a expansão da cidadania política foi marcada pelo desenvolvimento gradual do sufrágio universal. Estes direitos políticos foram institucionalizados no sistema político parlamentar de partidos políticos que competem entre si, estando, assim, ligados à instituição parlamentar e às assembleias e órgãos do governo local.

O elemento social da cidadania é constituído pelo direito ao nível de vida predominante e ao património social da sociedade. Estes direitos são significativamente realizados através dos serviços sociais e do sistema educativo» (idem:18 e 19). Marshall identifica como elementos de cidadania social o acesso aos benefícios de bem-estar social, aos cuidados médicos, aos programas de bem-estar, desde a educação à habitação.

Este autor defendeu também que a uma cidadania igual correspondia uma identidade cultural igual dos habitantes de determinado Estado. Porém, na prática, esta asserção possui duas limitações. Em primeiro lugar, a cidadania apenas tem aplicação em regimes políticos constituídos por Estados-Nação territoriais e soberanos; em segundo lugar, a cidadania exclui os não cidadãos esses Estados-Nação, originando uma segunda categoria de pessoas às quais não estão assegurados os mesmos deveres e os mesmos direitos. Assim, esta evolução da cidadania moderna assentou numa nova contradição, a que separa o cidadão do estrangeiro, isto porque a cidadania de desenvolveu no quadro dos Estados Nação e juridicamente acabou por se traduzir na noção de nacionalidade. O Estado limitava-se a reconhecer e a proteger esses direitos somente aos seus cidadãos, nacionais de um estado, e a recusá-los aos estrangeiros, principalmente aos estrangeiros nele residentes. Nesta perspectiva, a cidadania recria uma ligação ao Estado fundamentada na nacionalidade e era com base nessa ligação que cada cidadão tinha 
o direito de participar os seus assuntos. Por outro lado, a nacionalidade «era um atributo indeterminado e um meio legal para definir a pertença a um Estado ou comunidade» (0' Leary, 1996:7). Enquanto ligada à nacionalidade, a cidadania tornava-se não só elemento de integração das pessoas pertencentes ao mesmo Estado, mas também elemento de exclusão.

A cidadania moderna fundamentou-se na demarcação de identidades nacionais e na afirmação de uma pertença a uma sociedade nacional (uma comunidade cívica, politica e sociall. Deste modo, a cidadania era baseada na exclusividade e na rivalidade com os que não eram nacionais. Não se partilhavam nacionalidades, nem cidadanias, pois não se podia ser cidadão de dois países diferentes. Actualmente, observamos uma reformulação da noção de cidadania, com a emergência de novos direitos, alguns deles exigem um enquadramento global, enquanto outros exigem enquadramentos sub-nacionais ou locais. A globalização que torna o Estado-Nação pequeno demais para se defrontar com os grandes problemas e o localismo que o torna demasiado grande para resolver adequadamente pequenos problemas, estão a reformular a cidadania. Nas sociedades de consumo actuais, a cidadania traduz, «cada vez mais, o valor da qualidade de vida, do respeito por si próprio, pelos outros e pela natureza» (Cruz, 1998:41). É, principalmente, o consumidor «o sujeito destes novos direitos da vida e do ambiente, de qualidade, de participação mais intensa, de excelência» (ibidem). Estes novos direitos do consumidor (como por exemplo, o problema da segurança nuclear, da segurança dos oceanos, do buraco de ozonol não são satisfeitos apenas num quadro nacional, mas sim, num quadro global e mundial. Ao deixar de ser considerada unicamente nacional, a cidadania pode deixar de ser exclusiva e incompatível com outras cidadanias. De acordo com Braga da Cruz (1998:41), «a multiculturalidade das sociedades ocidentais desliga definitivamente também cidadania de nacionalidade, pluralizando as cidadanias, ou seja, configurando por um lado cidadanias plurinacionais e pluriculturais, e por outro lado cidadanias múltiplas, como a acumulação da cidadania europeia com as cidadanias nacionais da Europa o demonstra». Tal como podemos observar no processo de integração europeia, a Europa das Nações pode ser compatível, a nível cívico, com a Europa dos cidadãos e das regiões. A cidadania europeia fortalece-se com as cidadanias nacionais, assim como as cidadanias nacionais se fortificaram com as identidades regionais.

Na opinião de Jean-Yves Carlier (1998), o tempo fez evoluir as categorias de pessoas abrangidas pelos direitos las mulheres, as minorias, os negros) enquanto o espaço confrontou a nacionalidade com as migrações. Assim, para o autor, a cidadania deve ser «por um lado, a identifica- 
ção aberta e mútua; por outro, participação activa na salvaguarda dos direitos fundamentais (Carlier, 1998:129). Nesta óptica, a cidadania ultrapassa a nacionalidade porque exige que cada pessoa seja capaz de se pôr na pele de outra para defender direitos e interesses comuns, independentemente do seu sexo, língua, etnia, território de origem, religião, convicções políticas ou ideológicas, instrução, situação económica ou condição social.

Face à inevitabilidade e iminência dos fenómenos migratórios internacionais e à aceleração da globalização, o paradigma moderno de cidadania tornou-se obsoleto. Vários autores consideram que é necessário, num mundo global e plural como o nosso aumentar o potencial da cidadania, que é essencial a construção e o exercício de uma cidadania mais emancipatória. Se até este ponto estão definidos os direitos e os deveres dos cidadãos, isto é, a sua «igualdade enquanto cidadãos» (Castles, 1994:12), nada está definido relativamente às diferenças entre os vários membros da sociedade. As diferenças individuais estão relacionadas com o diferente acesso que alguns grupos sociais têm à cidadania formal. Como salienta Boaventura Sousa Santos, «ao consistir em direitos e deveres, a cidadania (...) transforma os sujeitos em unidades iguais (...) essa igualdade é profundamente selectiva e deixa intocadas diferenças, sobretudo as da propriedade, mas também as da raça e do sexo...» (Santos, 1994:207).

Inicialmente, as situações mais graves e flagrantes de desigualdade encontravam-se ligadas às mulheres, aos grupos sociais economicamente desfavorecidos e às minorias étnicas e religiosas. Actualmente, juntam-se a estes grupos os imigrantes. Neste novo contexto, «uma forma assimilacionista de cidadania, que nega a identidade e a especificidade dos grupos é discriminatória» (Castles, 1994:14). Para este autor, a cidadania corresponde a uma interdependência de direitos. Na sua análise de conceito de cidadania, para além dos direitos civis, políticos e sociais este autor propõe ainda de direitos de género e direitos culturais, considerando que estes dois últimos "são aspectos essenciais da cidadania nas sociedades contemporâneas" (Castles, 2000:24). 
O seguinte quadro apresenta uma síntese dos direitos conferidos ao cidadão de acordo com a análise de Stephen Castles:

\section{Quadro VIII - Direitos conferidos ao cidadão}

\begin{tabular}{|l|l|}
\hline Dimensão & \multicolumn{1}{c|}{ Direitos Conferidos } \\
\hline Civil & $\begin{array}{l}\text { Liberdade pessoal, liberdade de expressão, liberdade religiosa, igualdade } \\
\text { perante a lei, proibição de discriminação com base no género, raça ou } \\
\text { origem. }\end{array}$ \\
\hline Política & $\begin{array}{l}\text { Direito de voto, direito de ser eleito, liberdade de associação e de infor- } \\
\text { mação. }\end{array}$ \\
\hline Social & $\begin{array}{l}\text { Direito ao trabalho, direito à igualdade de oportunidades, direito a serviços } \\
\text { de saúde, assistência social e serviços sociais, direito à educação. }\end{array}$ \\
\hline Cultural & $\begin{array}{l}\text { Direito de acesso à língua da sociedade maioritária, direito a preservar } \\
\text { a língua e cultura das comunidades migrantes, direito a formas culturais } \\
\text { específicas, direito à educação, direito à comunicação intercultural e inter- } \\
\text { nacional. }\end{array}$ \\
\hline Género & $\begin{array}{l}\text { Direitos específicos para as mulheres migrantes que reconheçam a forma } \\
\text { como a sua opressão e exclusão da cidadania latravés de discursos e prá- } \\
\text { ticas, nos quais género, racialização e classe estão interligados) têm sido } \\
\text { historicamente construídas. }\end{array}$ \\
\hline
\end{tabular}

Fonte: Castles, S. (2000).«Underclass or Exclusion: Social Citizenship for Ethnic Minorities».

In: Ellie Vasta (ed.). Citizenship, Community and Democracy. London: Macmillan Press.

Este autor alerta ainda para a necessidade de um processo de re-democratização da sociedade de modo a criar condições para que os movimentos sociais e políticos das minorias se consigam desenvolver, considerando que «as lutas pelos direitos das minorias são, em última análise, lutas para a democracia e igualdade» (Castles, 2000:41).

Para que os imigrantes possam exercer os seus direitos de cidadania, sem qualquer preferência ou discriminação, Conceição Ramos (2003a:264) indica diversas medidas que podem ser aplicadas no sentido de lhes proporcionar uma melhor integração no nosso país: «criação de cursos pós- laboral de ensino do português; realização de cursos de formação profissional para possibilitar a aquisição de conhecimentos técnicos e de higiene e segurança no trabalho que muitas vezes é do total desconhecimento dos trabalhadores e propiciador de graves acidentes de trabalho, principalmente no sector da construção civil, onde os imigrantes do sexo masculino estão concentrados; facilitar o reagrupamento familiar, em especial, cônjuge e filhos menores com a obrigatoriedade de frequência das escolas oficiais; possibilitar o exercício de funções para as quais têm habilitações próprias e a frequência de cursos profissionais e universitários; proporcio- 
nar uma habitação condigna, o direito ao trabalho e à segurança social; incentivo à formação de associações culturais, recreativas e desportivas; medidas que permitam a igualdade de oportunidades e de participação cívica e implementação do respeito pela vivência na diversidade...».

Para Conceição Ramos (2003a: 266), deve-se «privilegiar orientações sobre a integração dos imigrantes assentes na primazia do valor da cidadania individual». Ao promover a participação no acesso ao emprego e a todos os recursos, aos direitos, aos serviços e aos bens é necessário abranger as minorias étnicas e os imigrantes, indo de encontro aos princípios constitucionais consagrados na Constituição da República Portuguesa. Ainda de acordo com esta autora, «as políticas sociais activas têm de se constituir como promotoras de um conceito de cidadania extensível a todas as pessoas legalmente residentes em Portugal. Os imigrantes e as minorias étnicas constituem grupos sobre os quais aumentam as preocupações ao nível da integração social» (ibidem).

Nogueira e Silva (2001) consideram que existem quatro importantes ideias que podem ajudar à construção de uma cidadania pós-moderna: a ligação da cidadania à comunidade política, através da promoção de uma ética de participação; a perpetuação dos direitos sociais desligados da economia de mercado; a construção de uma cidadania intima que represente uma possibilidade de concepção holística para a cidadania e, por fim, a existência de uma cidadania múltipla. Estas autoras (Nogueira e Silva, 2001:97), declaram que uma cidadania múltipla parece ser a forma de cidadania mais apropriada à pluralidade das sociedades modernas e ao recente crescimento do número e tipo de instituições sociais e políticas nas quais a cidadania pode ser exercida. A efectivação da cidadania numa variedade de contextos afasta o perigo de a associar apenas a um aspecto limitado, tal como a nacionalidade, a etnicidade ou a pertença a um grupo. A possibilidade de uma cidadania múltipla, permite uma participação que se pode alargar para diferentes espaços, sem esquecer nunca os contextos próximos, onde os problemas das pessoas com quem se vive se podem ver e tentar resolver, assim como o desenvolvimento de práticas de solidariedade que se pretendam incentivar. Segundo as autoras, «para atingir tais objectivos de promoção de cidadania será necessário formar ou ensinar com esta mesma orientação» (idem:98).

Carlos Amaral (2003:292) considera que actualmente a cidadania já não se refere «apenas à pertença a uma comunidade estato-nacional e ao direito a participar, através do voto, na sua estruturação política e na identificação dos seus principais governantes». Este autor afirma que «a contemporaneidade exige uma cidadania concreta e plural» (idem:307). Uma cidadania 
concreta para que seja possível corresponder ao complexo de identidades que manifestamos e plural para que a cada pessoa sejam reconhecidas as várias cidadanias que detém, relativas à pluralidade de comunidades significativas em que se insere. Para o autor, a cidadania cosmopolita deverá corresponder ao regime jurídico dos direitos do homem, considerando que desde a adopção da Declaração Universal dos Direitos do Homem todas as pessoas passaram a usufruir de uma cidadania cosmopolita; a cidadania europeia, definida no Tratado da União, que possuem aqueles que são cidadãos de um dos países da União Europeia lpassámos a ser cidadãos portugueses e cidadãos da União Europeia, a partir da entrada em vigor do Tratado de Maastricht de 1992); a cidadania estatal correspondente ao regime jurídico do nosso Estado, a cidadania regional resultante da autonomia política das Regiões; e as cidadanias particulares da escola, do sindicato, da associação desportiva, da igreja, etc., relativas à autonomia que detêm no quadro específico das actividades que desempenham.

A questão da cidadania europeia, decorrente da estabilização da Comunidade Europeia na década final do século, afirma-se como sendo «sobretudo uma ideia humanista que consiste em construir uma grande Europa, caracterizada por diferenças culturais, diferentes concepções económicas, realidades naturais diferentes, mas unida pelo sentimento de pertencer a uma civilização comum. É a partir de uma cultura democrática partilhada que os Europeus se reconhecerão como seus cidadãos» (Relatório da Comissão Europeia sobre a educação e a formação, 1997:16 e 17 in Roldão, 1999:14). São ainda enunciados neste relatório os valores comuns desta civilização europeia: «os direitos do homem; a dignidade humana; as liberdades fundamentais; a legitimidade democrática; a paz e a rejeição da violência como meio ou método; o respeito pelos outros; a solidariedade humana (no interior da Europa e face ao mundo na sua globalidade); o desenvolvimento equitativo; a igualdade de oportunidades; os princípios da argumentação racional: a ética da evidência e da prova; a preservação do ecossistema; e a responsabilidade individual» (idem:15). É igualmente sublinhado que o ensino destes valores deve constituir-se como «tarefa de todos os professores».

O autor Will Kymlicka (1995) é a favor de uma «cidadania multicultural» que reconhece a importância da cultura para a identidade assim como o sentido de local e de espaço. Uma vez que a abordagem liberal de cidadania implica uma cidadania pública, universal e cega perante a cultura, acaba por implicar manter as minorias culturais vulneráveis às injustiças nas mãos da maioria e na exacerbação dos conflitos etnoculturais. Como a defesa tradicional liberal dos direitos naturais não pode resolver os problemas das diferenças dentro do estado, Kymlicka sugere uma teoria de 
direitos de minorias. Uma teoria compreensiva de justiça num Estado multicultural que abarque direitos universais, delegados para os indivíduos independentemente da sua pertença a qualquer grupo específico, e também certos direitos diferenciados para grupos ou um estatuto especial para indivíduos pertencentes a culturas minoritárias. A importância da identidade étnica é que ela permite um contexto cultural no qual os indivíduos se desenvolvem e por isso fornece os parâmetros para as escolhas individuais. Para este autor, as opções que têm significado para os indivíduos depende da cultura societal e da compreensão da história e linguagem dessa mesma cultura. Ele defende que a cidadania não pode ser um estatuto exclusivamente individual (numa perspectiva liberal) porque tem significado para a pessoa apenas no amplo contexto cultural de pertença grupal, mas deve ser enraizada numa noção de grupo social, reclamando, deste modo, uma cidadania diferenciada. Assim, põe em causa a pretensa igualdade liberal, ao advogar uma mudança no conteúdo da cidadania através da inclusão de direitos diferenciados por grupo, a par dos direitos individuais.

Como temos vindo a constatar a cidadania é um conceito polissémico e uma realidade multifacetada. Significa liberdade, solidariedade social, participação igualitária e qualidade de vida. Significa ainda nacionalismo e patriotismo, enquanto agregada ao Estado-Nação e à sua defesa, identificando-se com a comunidade nacional, com os seus valores sociais e com a sua tradição cultural. São estes os valores da cidadania que não conseguem encontrar mais satisfação senão num quadro muito diverso e multiforme de instâncias sociais.

\section{A CIDADANIA EM CONTEXTO ESCOLAR INTERCULTURAL}

A implementação e prática de uma educação para a cidadania efectiva nas nossas escolas necessitam de um esforço educativo premeditado e constante ao longo de toda a escolaridade, visando preparar as crianças e jovens para a participação na vida da sociedade através do seu enriquecimento global como pessoas.

A urgência em repensar a educação e seu papel no nosso mundo em acelerada mudança e a necessidade de reestruturar a organização curricular do ensino básico, expressa na reorganização curricular do ensino básico (Decreto-Lei n. ${ }^{\circ}$ 6/2001), surge do reconhecimento da importância da educação inicial e contínua do saber e das aprendizagens do aprender a conhecer, aprender a fazer, aprender a viver juntos e aprender a ser, que constituem os pilares que devem alicerçar e nortear as aprendizagens 
do ser humano ao longo da vida e que devem ser considerados como condições imprescindíveis para que a educação para a cidadania seja apreciada como «um valor urgente e vital perante um mundo complexo e não isento de ameaças ao próprio reconhecimento dos direitos de cidadania a quem nele habita» (Fonseca, 2002:10).

Actualmente, as sociedades democráticas têm demonstrado um interesse nas formas como os seus jovens desenvolvem e adquirem consciência dos seus direitos e das suas responsabilidades enquanto cidadãos e como aprendem a participar nos assuntos públicos. A questão do significado de uma cidadania eficaz e do papel da educação em construir uma cultura cívica é uma questão importante, não só para os governos e instituição escolar mas também para a sociedade em geral. A educação para a cidadania adquiriu uma importância particular em países que adoptaram recentemente sistemas políticos democráticos, como podemos considerar o caso do nosso país onde a mudança aconteceu após a revolução de 25 de Abril de 1974, permitindo caminhar nos trilhos da democracia e alcançar a normalização democrática, mas também despertou a preocupação em países onde esses sistemas estavam há muito estabelecidos e onde se tinham registado sinais de baixa afluência de votantes, recusa de participação no processo político e graves incidentes de violência contra as minorias étnicas e culturais. Aliás, o conceito de cidadania que ressurge no pós 25 de Abril corresponde ao «conceito de cidadania democrática das sociedades ocidentais da segunda metade do século, marcada pelo pós-guerra e pautada pela matriz de valores corporizada na Declaração Universal dos Direitos Humanos. A cidadania, nestes termos, é definida essencialmente pela recusa do totalitarismo, pela liberdade de opção ideológica e por um sentido de participação activa na vida pública» (Roldão, 1999:11).

De facto, este reconhecimento da centralidade da promoção da cidadania parece ser generalizado e está presente nas principais preocupações de professores, educadores e políticos e tem sido objecto, quer explícito, quer implícito, dos governantes desde há algum tempo. No entanto, notam-se incoerências e contradições nos discursos políticos e nos normativos vindos do poder central relativos à educação e ao ensino. Assim, «enfatizam retoricamente a suprema importância da educação para a democracia e para a cidadania na luta contra a apatia e a alienação das camadas mais jovens e dos adultos e, por outro lado, defende-se a domesticação da educação pública, a neutralidade das escolas, tornando-as uma espécie de agências de gestão orientadas para o mercado, para a competição económica e a aprendizagem individual» (Lima, 1996 cit. por Nogueira e Silva, 2001:99). 
Neste contexto, o sistema educativo é identificado como um elemento chave para a promoção da educação para a cidadania e para a formação de futuros cidadãos que participem activamente e de modo crítico na construção de uma sociedade mais justa e solidária, colocando como valores fundamentais a democracia, os direitos humanos, a tolerância, ... e a escola é reconhecida como um local de aprendizagem e convivência social que para além de oferecer, a quem ela acede, um espaço físico e organizacional, deve oferecer igualmente um espaço democrático de cidadania, um espaço relacional, de convívio, de cooperação e de resolução de conflitos.

O grande objectivo final da educação para a cidadania é a participação responsável e consciente dos cidadãos na vida pública do país, quer através dos processos de representação política, quer através do empenho nas instituições da sociedade civil, e com compromissos nos princípios e valores essenciais da democracia portuguesa. Esta participação responsável reivindica um conjunto de conhecimentos, competências e capacidades de intervenção que a escola deve desenvolver. Deste modo, consideramos que a educação escolar tem uma grande responsabilidade no desenvolvimento dessas competências e capacidades cívicas através dos procedimentos da prática da vida escolar, com recurso a metodologias activas e da intervenção não apenas ao nível do currículo explícito, mas também ao nível do currículo oculto ${ }^{6}$.

Ao conceito de escola que apenas transmite conhecimentos opõe-se, actualmente, o conceito de escola que ensina a fazer uso do conhecimento e da informação na compreensão da realidade, sendo que esse

6. O conceito de currículo oculto «acentua resultados e processos do ensino escolar que, não sendo explícitos nos planos curriculares e programas de ensino, constituem, no entanto, parte integrante e efectiva da experiência do aluno na escola» (Ribeiro, 1992: 82). Este conceito engloba todo o conjunto de aprendizagens paralelas (geralmente respeitantes a atitudes, sentimentos e valores) que, não sendo directamente referidas pelo currículo explícito (nos objectivos, conteúdos e processos de ensino-aprendizagem propostos) decorrem da própria organização pedagógica e dos elementos integrantes da vida e instituição escolares. Assim, essas aprendizagens «não resultam da intenção deliberada e explícita de as induzir mas ocorrem como resultado subjacente ao modo como se organiza e institucionaliza o processo de ensino - aprendizagem na escola» (ibidem). Este currículo está relacionado, entre outros aspectos, «com a estrutura sócio-organizacional da escola e do ensino, com o sistema e clima de relações sociais na escola e na classe, com a natureza da interacção social professor - alunos, padrões de autoridade e exercício de liberdade em situações formais de ensino, mecanismos e práticas de avaliação ou promoção escolar, com incentivos, sanções e motivações» (ibidem). Podemos ainda acrescentar que o currículo oculto é o currículo «através do qual as pessoas aprendem lições significativas sobre justiça, poder, dignidade e valor próprio» (Apple e Beane, 2000: 37). 
conhecimento ajuda a formar cidadãos mais participativos e intervenientes, detentores de saberes e de capacidades de agir e de conviver em sociedade.

Também Américo Peres (1999: 124) partilha desta opinião ao afirmar que «a escola não pode quedar-se na mera transmissão de conhecimentos I processo que se desenvolve, muitas vezes, de uma forma pouco instrutiva, limitando-se a um ensino abstracto, mnemónico, verbalista e descontextualizado), mas deve assumir o seu papel socializador, educando desde e para os direitos humanos, isto é, preparar cidadãos e cidadãs conscientes e livres, comprometidos com a reconstrução de uma sociedade mais justa e democrática».

No entanto, para um cidadão ser capaz de viver em sociedade deve ter desenvolvido competências de reflexão acerca da sociedade em que está inserido para conseguir intervir nela de forma a transformar a sua qualidade de vida. Este processo de aprendizagem, aquisição e desenvolvimento de competências cívicas é o que se designa por educação para a cidadania. A educação para a cidadania visa desenvolver nos alunos atitudes de auto estima, de respeito mútuo, de solidariedade, a aceitação e o respeito pelas diferenças, o assumir das suas responsabilidades, a apropriação de regras de convivência, de valores fundamentais da vida em sociedade e de competências inerentes à conduta democrática que conduzam à formação de cidadãos solidários, autónomos, participativos e civicamente responsáveis. Pretende igualmente estimular a participação activa dos alunos na vida da turma e da comunidade em que estão inseridos, bem como proporcionar momentos de reflexão sobre a vida da escola e os princípios democráticos que regem o seu funcionamento.

De acordo com António Fonseca (2000: 27), aprender a ser cidadão é, «simultaneamente, uma tarefa cognitiva e socioafectiva, em cuja concretização a pessoa exerce um papel activo, tornarmo-nos cidadãos adquire uma natureza desenvolvimental e trata-se de uma tarefa para a qual concorrem domínios diversos do desenvolvimento psicológico, como sejam o desenvolvimento cognitivo, estético, moral e pró-social».

\subsection{Que conceito de educação para a cidadania}

No sentido de clarificar ideias sobre a educação para a cidadania, vamos recorrer às opiniões expressas por diversos autores sobre o conceito de educação para a cidadania em contexto escolar. 
Partimos do princípio de que educar para a cidadania implica educar para a consciencialização da relação recíproca entre direitos e deveres, pois consideramos importante que os alunos estejam conscientes dos seus direitos mas também conscientes das suas responsabilidades enquanto cidadãos.

Para Leite e Rodrigues (2001:25) «a educação para a cidadania representa mais do que a educação cívica, a educação para a civilidade ou para a participação política. A educação para a cidadania tem o sentido mais amplo de formar indivíduos promovendo a interacção num contexto comum, sendo a escola apenas um dos múltiplos lugares onde essa interacção acontece». Também Perrenoud (2001:99) partilha desta opinião dizendo que se inscreve «no campo da educação para a cidadania, bem mais além da simples instrução cívica. Trata-se, não apenas de valores e de saberes, mas de competências, logo de uma formação, ao mesmo tempo teórica e prática, mobilizável nas situações reais da vida, na escola e fora dela, desde a infância e ao longo de todos os ciclos de vida».

A educação para a cidadania deve preocupar-se com o civismo dos cidadãos ao educar os alunos para uma intervenção cívica, pois o civismo é um direito e simultaneamente é um dever dos cidadãos, mas a cidadania não se resume a um conjunto de direitos e de deveres, «ela é, também um modo de ser, uma implicação pessoal na construção da sociedade, dimensão que não se esgota numa listagem de direitos/deveres, nem sequer em nenhuma constituição» (Praia, 1999:17). Esta autora pondera ainda que não é correcto separar as finalidades da educação para a cidadania da educação para o civismo, mas considera esta última como um capítulo da primeira.

A educação para a cidadania democrática «é o conjunto de práticas de actividades cuja finalidade é tornar os jovens e os adultos melhor preparados para participar activamente na vida democrática, através da assunção e do exercício dos seus direitos e responsabilidades sociais» (Silva e Figueiredo, 1999:43).

De acordo com Leite e Rodrigues (2001:24), a educação para a cidadania «não se resume à aprendizagem dos direitos e deveres dos cidadãos mas passa essencialmente pela construção da escola democrática onde seja possível vivenciar situações de mútuo (re)conhecimento, valorização e respeito, que assumam um carácter formativo e potencializador dessa formação nos vários contextos de vida dos indivíduos. Trata-se de educar na cidadania, desenvolvendo acções coerentes com as metas expressas no currículo e que, ao darem voz a experiências e saberes 
diversificados, criam condições para uma educação orientada por princípios democráticos».

Para Figueiredo (1999:13-14), «educar para a cidadania pressupõe educar na cidadania pela cidadania, ou seja, para a liberdade pela liberdade e com responsabilidade». Desta forma, educar para a cidadania implica práticas pedagógicas devidamente organizadas e coerentes com os valores que a organização escolar defende. Esta autora refere ainda que o «conceito de cidadania torna-se muito mais consistente quando permite a participação directa de cada pessoa nas várias formas de vida pública a nível social, cultural, político e profissional» (idem:35).

Uma «educação para a cidadania activa e democrática exige que a própria escola não se esquive à responsabilidade de ser ela própria alvo de questionamento, de forma a tornar-se um local privilegiado de participação e de educação para a participação» (Nogueira e Silva, 2001:100). Sendo assim, a escola enquanto lugar de decisão que pode decidir a sua gestão curricular, pensar as suas práticas pedagógicas de forma emancipatória e reflexiva, capaz de gerar mudança, deverá ser um espaço dialogante e reflexivo envolvendo os diferentes actores em acção permitindo o aparecimento de uma cultura escolar com práticas pedagógicas activas e uma organização escolar dinâmica preconizada nos princípios e nos normativos que estão na base da política educativa actual.

Para se verificar esta mudança é necessário o reconhecimento do acto educativo como acto social e o reconhecimento da escola como uma organização ou sistema social, promotora de mudanças sociais e preparada para responder aos novos desafios que surgem na sociedade. Educar para a cidadania engloba também a criação de oportunidades de desenvolvimento nos alunos da auto-estima, do auto-conhecimento, do conhecimento e respeito pelo «outro». Espera-se que a escola actual mobilize e incorpore saberes e recursos de modo a vivenciar o contacto das diversas culturas e da democracia, tornando-a num espaço promotor do sucesso educativo para todos e permitindo o desenvolvimento de competências e saberes necessários para o exercício da cidadania. No quadro destas ideias, aprender a viver e a conviver com os outros são os pilares da formação cívica das crianças e jovens.

Na continuidade destas ideias, ainda no âmbito da organização escolar, é importante apresentar a opinião de Michael Apple e James Beane (2000) que defendem uma mudança na instituição escolar, de modo a que a esta se transforme numa escola democrática, surgindo, assim, o conceito de 
escola democrática. Para estes autores, as escolas democráticas «estão intensamente envolvidas na tentativa de encontrar maneiras práticas de aumentar a participação significativa de todos os intervenientes na experiência educacional, incluindo também pais, residentes locais e, muito especialmente, os alunos» (Apple e Beane, 2000:170). Este objectivo é alcançado através da criação de comunidades de aprendizagem dentro de cada escola e entre a escola e a comunidade em geral. Ainda de acordo com estes autores, «estas comunidades, pela sua própria natureza, são diversificadas, diversidade esta que não é vista como um problema mas como algo positivo (...), incluem pessoas que espelham diferenças de idade, cultura, etnia, género, classe socioeconómica, anseios e capacidades, diferenças que enriquecem tanto a comunidade quanto as opiniões que podem ser tomadas em consideração» (idem:33).

Concordamos com Carla Figueiredo (2002:54 citando Audigier, 2000) quando afirma que «a educação para a cidadania não é um conteúdo escolar ou um conjunto de actividades: é uma finalidade essencial das políticas educativas». A concretização para a cidadania faz-se através de «experiências diversificadas e de práticas sociais, sendo necessário reconhecer a importância de todas as influências educativas (formais, informais, não formais)» (idem:55 citando Birzea, 2000). A educação para a cidadania está relacionada com todos os aspectos da vida dos alunos na escola, tem a ver com as diversas disciplinas, com os espaços não disciplinares e com outros aspectos da participação dos alunos na vida da escola. Assim, a «educação para a cidadania não se concretiza através de um discurso, de uma retórica em torno de valores e/ou virtudes, mas sim através de experiências de vida, sendo, por isso, mais uma prática do que discurso, é mais uma acção/reflexão do que conteúdo e/ou informação» (ibidem). Podemos, então, concluir que o desenvolvimento de competências de cidadania não se efectua apenas pela comunicação de mensagens de conteúdo cívico que o professor nas suas aulas transmite, mas adquirem-se, principalmente, através de práticas de cidadania, dentro e fora da sala de aula, fomentadas por propostas de origem diversificada e a partir de diversas situações de vida escolares ou não escolares.

Consideramos importante salientar que a educação para a cidadania se concretiza ao longo de todo o percurso educativo dado que «é um processo de desenvolvimento de competências cognitivas, sociais e afectivas desenvolvidas em 'situações' e em estreita ligação com um conjunto de valores que caracterizam as sociedades democráticas» (ibidem). Estas competências (que podem ser entendidas como os alicerces) necessitam de posteriores concretizações em contextos adequados e propícios de modo a firmar e a actualizar essas mesmas competências. 
Podemos identificar, de acordo com António Fonseca (2002), várias perspectivas sobre a educação para a cidadania e a formação cívica que constituem, no seu conjunto, um quadro conceptual, de entendimento e de análise dos dilemas intrínsecos à obtenção de determinados resultados por meio de uma acção educativa promotora do desenvolvimento de competências de cidadania. A primeira perspectiva resume-se em encarar a educação para a cidadania e a formação cívica do aluno como um instrumento de regulação social, com a função de adaptar as pessoas ao sistema social vigorante; a segunda encara-as como um factor de transformação social; a terceira considera-as como um instrumento de mudança individual, por último; a quarta perspectiva tem como objectivo ensinar e desenvolver competências de cidadania que possibilite ao aluno a escolha autónoma do melhor caminho de envolvimento e de participação social, de acordo com as suas preferências e motivações. No contexto destas quatro perspectivas, duas possuem uma orientação educativa de ênfase mais social - a regulação social e mudança social, enquanto as outras duas têm uma orientação de ênfase mais individual - a mudança individual e a realização de escolhas. Assim, o desenvolvimento de competências de cidadania terá sempre de atender a uma dimensão pessoal e a uma dimensão social. Para Fonseca (2002: 18), «mesmo quando a intervenção educativa age essencialmente a nível individual la situação mais comum), jamais se poderá esquecer a necessidade de inserir a formação cívica da pessoa num contexto social determinado, o qual possibilita, e ao mesmo tempo limita, as oportunidades de intervenção cívica actuais e futuras dessa pessoa». Ainda de acordo com o mesmo autor, «ter consciência que ser cidadão é uma tarefa que só se realiza num dado espaço social facilita, desde logo, que se avaliem quais as reais possibilidades de acção cívica e ajuda a pessoa, finalmente, a compreender em que medida poderá contribuir para a evolução da sociedade» (ibidem).

A autora Maria do Céu Roldão (1999) distingue duas vertentes com dois níveis de profundidade relativamente à educação para a cidadania. Esta autora considera que existe uma vertente de formação cívica, situada entre a socialização e a educação para os valores, «que diz respeito aos conhecimentos e aos comportamentos necessários à inserção na vida civil da sociedade e nos seus mecanismos jurídico-políticos» (Roldão, 1999:12). Esta educação cívica, que a autora considera de nível mais superficial, «faz contudo parte da função educativa da escola e permite que a partir dela se construam níveis mais profundos de participação social e de práticas informadas por valores» (ibidem). São exemplos desta vertente, o conhecimento dos órgãos políticos, saber o modo como são investidos e como se intervém na sua acção, ou a competência necessária para agir civicamente. Descurar esta vertente cívica mais elementar pode 
comprometer a eficácia da educação para a cidadania ao nível dos valores e da intervenção social. A educação para a cidadania, de nível mais profundo, não se esgota na formação de um cidadão nos valores democráticos e abrange «as práticas construtoras da identificação cultural, a inserção nas rotinas sociais e convenções de uma época, os rituais sociais, que podem não ser necessariamente valoráveis em termos éticos» (ibidem).

A educação cívica engloba as temáticas dos direitos e deveres. Adalberto Dias de Carvalho (2001:24) reflecte que com estas temáticas, duas componentes suas são delineadas: «por um lado, uma educação dos deveres que erige como objectos de acções responsáveis prioritariamente os outros indivíduos; por outro, e em simultâneo, uma educação dos direitos que acentua as prerrogativas dos outros relativamente ao próprio». Nesta ordem de ideias, "os direitos dos outros constituem eticamente deveres para mim e só nessa medida é que, inversamente, estes o são para eles, enquanto os direitos dos outros não constituem ipso factu, eticamente também, direitos para mim mas apenas direitos meus, na medida em que o são para os outros» (ibidem).

\subsection{A educação para a cidadania e a reorganização curricular}

A reorganização curricular do Ensino Básico, instituída pelo Decreto-lei n. ${ }^{\circ}$ 6/2001, de 18 de Janeiro representa o culminar de um longo processo desenvolvido nos últimos anos em relação aos currículos do Ensino Básico.

O Decreto-Lei n. ${ }^{\circ}$ 6/2001 trouxe inovações curriculares significativas constando na sua reorganização, entre outras medidas, o desenvolvimento da educação para a cidadania e a implementação de três novas áreas curriculares não disciplinares - Área de Projecto, Estudo Acompanhado e Formação Cívica.

Este Decreto-Lei faz referência ao Documento Orientador das Políticas para o Ensino Básico, publicado pelo Ministério da Educação em 1998, sublinhando que a «escola precisa de se assumir como um espaço privilegiado de educação para a cidadania e de integrar e articular, na sua oferta curricular, experiências de aprendizagem diversificadas, nomeadamente mais espaços de efectivo envolvimento dos alunos e actividades de apoio ao estudo» (Decreto-lei n. ${ }^{0}$ 6/2001:258). Neste sentido, a alínea d) do artigo terceiro deste Decreto-Lei realça a «integração, com carácter transversal, da educação para a cidadania em todas as áreas curriculares». Também a nova área curricular não disciplinar - Formação Cívica, 
é concebida como um «espaço privilegiado para o desenvolvimento da educação para a cidadania, visando o desenvolvimento da consciência cívica dos alunos como elemento fundamental no processo de formação de cidadãos responsáveis, críticos, activos e intervenientes, com recurso, nomeadamente, ao intercâmbio de experiências vividas pelos alunos e à sua participação, individual e colectiva, na vida da turma, da escola e da comunidade" (idem:260). Ainda no ponto um, do artigo sexto, é sublinhado que «a educação para a cidadania bem como a valorização da língua portuguesa e da dimensão humana do trabalho constituem formações transdisciplinares, no âmbito do ensino básico» (ibidem).

Também faz parte integrante desta área o desenvolvimento da capacidade de aprender a viver e a comportar-se segundo o seu estatuto e papel, reconhecendo o valor do estatuto e papel do outro. Isto implica que o aluno desenvolva o conhecimento de si próprio e seja capaz de situar no lugar do outro, substituindo o seu natural egocentrismo pelo heterocentrismo, capacidade de crucial importância para a Educação para a Cidadania.

À luz da legislação vigente importa reflectir sobre o significado do conceito de cidadania e na forma de fazer da escola um espaço onde se adquirem e desenvolvem competências democráticas, dando oportunidades aos alunos de emitir opiniões e de participarem no seu próprio processo educativo, juntamente com os professores, pais, pessoal não docente, poder local, enfim, toda a comunidade educativa, já que a todos diz respeito.

Abordaremos novamente esta questão no ponto 5, no capítulo III deste trabalho, de uma forma mais aprofundada.

\subsection{Os valores e a educação para a cidadania}

As sociedades actuais são cada vez mais complexas. 0 tempo em que vivemos caracteriza-se por um ritmo vertiginoso de mudança. Mudanças sociais, culturais e tecnológicas afectaram e continuam a afectar, de forma intensa, a sociedade em que vivemos. Novos valores originaram novos problemas que juntamente com as incertezas próprias de uma época de mudança constituem características de uma sociedade em que o conhecimento determinará o modo como cada indivíduo poderá intervir.

Educadores, professores, académicos, políticos, de um modo geral, parecem concordar que estamos perante uma crise da educação e poucos 
duvidarão da sua extensão e gravidade. Apesar de esta crise afectar a cultura, em geral, e a instituição educativa e o discurso pedagógico, em particular, consideramos que a educação não pode prescindir dos valores e da formação ética dos alunos. A crise não é apenas consequência da situação económico-social, da inadequação das estruturas educativas às novas necessidades e exigências tecnológicas e sociais e da insuficiência de meios. É consensual esta ideia de crise de valores, cujas manifestações mais visíveis são as condutas de matriz individualista, a não solidariedade, a intolerância e a agressividade. Estamos perante uma crise de sentido, crise na relação da educação com os valores e com o ser humano.

É pois indiscutível a presença dos valores nos discursos e nas práticas educativas numa sociedade na qual já não existe um consenso global de valores. Evoluímos numa sociedade pluralista a nível político, religioso, moral e filosófico e preparar o ser humano para entrar nessa sociedade problemática é a tarefa da educação. Como já sabemos, o processo de aquisição de valores inicia-se desde logo, muito antes de as crianças irem para a escola. 0 ambiente cultural da família é a primeira grande influência das atitudes e dos valores da criança. Essa influência continuará e completa-se posteriormente através de outros agentes, entre eles e desempenhando um papel fundamental, a escola. Assim, é fundamental promover uma genuína educação para os valores e que esta prepare as pessoas para conviverem com contradições quotidianas, discernindo entre o bem e o mal, o justo e o injusto em defesa do bem comum sem caírem em cepticismos radicais ou em dogmatismos.

A palavra valor vem do latim «valore», que significa aquilo que vale alguma coisa e tem merecimento. Tem valor o que é considerado belo, digno e verdadeiro, segundo um juízo pessoal feito de acordo com os padrões sociais de determinada época. A capacidade de criar valores e de valorizar acções e objectos é uma das características do ser humano. Os valores têm um papel importante no equilíbrio da personalidade, guiando os comportamentos e orientando as tomadas de decisão. Os valores compõem um conjunto interiorizado de princípios que estimulam a pessoa a actuar de uma forma previsível e mais ou menos estável, auxiliando, de certa forma, na antecipação e previsão das condutas, bem como nas consequências das mesmas. Deste modo, o valor será um determinante de um comportamento humano, tanto das suas condutas, como das suas atitudes, ocupando parte central da personalidade das pessoas. Os valores estão ligados à existência humana, possuindo, simultaneamente, duas dimensões. Uma dimensão objectiva de que os valores são fins, objectivos que regulam a conduta do ser humano, e uma dimen- 
são subjectiva na medida em que estão profundamente ligados às motivações e desejos, dependendo da energia sentimental e emocional que estimula as acções.

Podemos identificar algumas características dos valores e que servirão para uma melhor compreensão desta temática no âmbito da educação para a cidadania. Segundo Ramiro Marques (2002:16), os valores «não são coisas mas sim qualidades que as coisas possuem mas que não estão nelas de um modo sensível; os valores são estimados e inferidos, através da inteligência, do sentimento e das emoções; estimar um valor é apreendê-lo; os valores produzem reacções nas pessoas; os valores recebem grande poder energético dos afectos e são motivadores das atitudes e comportamentos das pessoas; apesar de a inteligência ser necessária ao processo de apreensão de valores, são as emoções e os sentimentos que mais pesam neste processo; os valores não são transmitidos ou construídos mas sim descobertos através da identificação, do testemunho, do exemplo e da vivência; os valores possuem bipolaridade e hierarquia, ou seja, os valores podem ser colocados num determinado ponto entre um extremo positivo e um extremo negativo (bipolaridade) e subordinam-se uns aos outros, uma vez que uns são mais valiosos do que outros (hierarquia)».

O conceito de cidadania, que é um conceito historicamente evolutivo e complexo, é um conceito que se refere a valores. Para Maria Praia (1999:8), o «conceito de cidadania assumiu através dos tempos um significado axiológico diferenciado e evolutivo, trazendo concomitantemente progressivas exigências de redefinição de quadros referenciais, quer teóricos, quer práticos, quer individuais, quer institucionais».

No entanto, nem sempre existe consenso sobre a matriz axiológica em que se deve estruturar o conceito da educação para a cidadania. Quando alguém afirma que é necessário educar para os valores, refere-se aos valores que essa pessoa considera ser os mais apropriados à construção do modelo de cidadão que tem como ideal. Porém, como todo o processo educativo decorre de valores, podemos considerar que todo o acto educativo é valorativo e que exige uma opção valorativa, para a qual é preciso uma fundamentação. Essa opção e fundamentação darão origem a conceitos estruturantes, sendo necessário hierarquizá-los, pois eles irão determinar os conteúdos e as metodologias mais ajustadas. A educação para a cidadania «deve conter uma dimensão de educação para os valores, mas não deve esgotar-se numa educação para os valores; e muito menos no que alguns autores norte-americanos chamam a educação do carácter» (Silva, 2000:83). De acordo com Augusto Santos Silva (2000), 
quando dizemos educação para a cidadania, queremos dizer educação na cidadania. Para este autor, não se trata de transmitir, mais ou menos formalmente, valores considerados como pressupostos necessários para o exercício da democracia, mas sim de «através do exercício da democracia, através da nossa relação de uns com os outros e da nossa participação (multiforme) nos assuntos comuns, na res publica, formarmos e transformarmos quadros de referência aceitáveis pelos participantes» (idem: 83 e 84).

A escola pode e deve promover valores inerentes ao ser social no processo educativo, tais como o respeito por si próprio e pelos outros e a tolerância ${ }^{7}$, fundamentais à convivência democrática numa sociedade multicultural. Uma escola promotora de valores não pode ser neutral, devendo contribuir para a consciência axiológica dos seus alunos, advogando a defesa de certos valores em nome da sua evidente mais-valia para a melhoria da vida individual e social, mas não esquecendo que é necessário evitar a transmissão inculcadora e contribuir para a construção da consciência axiológica. De facto, os valores não devem ser inculcados, mas induzidos a partir da experiência axiológica, aberta à liberdade e autonomia de quem se educa. Concordamos com Leite (2002:25) quando refere que «os valores vivem-se, não se adquirem através de conceitos abstractos». Deste modo, é importante possibilitar a abertura ao outro e ao mundo, sem thes impormos valores, mas que ajudemos os alunos a construir opções alicerçadas em preocupações éticas, que em conjunto, em diálogo respeitador com o outro, havemos de ser capazes de desvendar.

A problemática axiológica para Manuel Patrício (1993) deverá ser enquadrada por uma axiologia educacional. O professor pode intervir ao nível da hierarquia axiológica através da relação educativa «durante a qual o educador pode induzir no educando actos de preferência mais altos, constitutivos de uma hierarquia axiológica superior» (Patrício, 1993:254). «Cada vez mais se impõe à reflexão pedagógica fundamental (...) a evidência da posição central da pessoa humana no acto e no processo educativos. Assim, a filosofia axiológica de Scheler, que culmina com o seu personalismo ético - um personalismo que é da pessoa individual e também da

7. A noção de tolerância que defendemos expressa uma aceitação do «outro» e respeito pela sua alteridade, implica também o verdadeiro reconhecimento, o qual pressupõe uma relação dialógica entre o «eu» e o «outro». A tolerância tem grande importância na interpretação e explicação do fenómeno humano, na medida em que este implica a relação entre as pessoas, encaradas como sujeitos portadores de identidade e dignidade próprias. 
pessoa comum -, conserva intacta a sua riqueza para o pedagogo contemporâneo» (idem:266). Patrício salienta igualmente a contribuição de Nicolai Hartmann (1882-1950) que salienta o carácter situado da pessoa Itambém referido por Ortega e Gasset, José Marinho, Heidegger e Sche(er). Na perspectiva deste autor, a educação deve ser situada para responder à estrutura real da pessoa, deve ser organizada de modo a promover e favorecer a capacidade criadora e deve ser orientada para a totalidade do tempo da vida pessoal, para a purificação e aprofundamento da interioridade. O que devemos transmitir às gerações novas é a totalidade do legado espiritual (a cultura) e a criatividade vital que permitiu criá-lo. Este autor considera que é necessário construir, no plano da ética, «uma axiologia dos costumes, a fim de atender simultaneamente à relatividade da mediação e ao absoluto dos valores» (idem:279). Relativamente ao estatuto da axiologia educacional, Patrício considera que ela assume o carácter de uma axiologia aplicada à educação e o método mais adequando a esta axiologia é o método hermenêutico.

Educar para os valores e pelos valores da cidadania e da democracia pressupõe tornar a educação mais cívica e democrática. Braga da Cruz (1998:47) considera que «civilizar» a educação é «um desafio que se confunde com as exigências da sua democratização social e política. Mas a educação cívica é sobretudo uma educação para os valores da cidadania e da democracia, a saber, a liberdade, a participação responsável, a solidariedade social, a defesa e o respeito pela vida e pela natureza, por um lado, e a competitividade e a inclusividade, por outro lado».

Como sabemos a formação cívica engloba a temática dos direitos e deveres, a aptidão para entrar na vida pública de forma interventiva e responsável, a capacidade crítica para escolher e a capacidade de abertura tolerante relativamente a outras posições. No entanto, para que o desenvolvimento destas competências e atitudes não degenerar em conflituosidade é necessário que cada um assimile e promova o sentido de alteridade no seio de uma comunidade de relações caracterizada pelo diálogo ético. Nesse sentido, a escola de hoje deve promover uma educação que desenvolva no aluno o compromisso consigo mesmo e com o social, trabalhando os conteúdos de forma que se desperte no aluno um diálogo interior e constante que conduza ao exercício da escolha do caminho a seguir e conduza ao exercício da cidadania. Neste caminho está presente a capacidade de ser autónomo, a aceitação do livre exercício do raciocínio e do questionamento constante. Deste modo, admitimos que se poderão cultivar valores e convicções democráticas e se poderá combater o individualismo, talvez um dos grandes males da sociedade actual. 
Esta postura da escola levará à formação de cidadãos que interagem com os outros que o rodeiam e com o mundo, em harmonia e com respeito. Pensamos que para que se concretize esta formação de pessoas com valores, críticos, autónomos e livres que contribuam para uma sociedade melhor, deve-se ter em atenção, desde os primeiros anos de ensino, a formação global do aluno como pessoa, o seu desenvolvimento moral e desenvolvimento intelectual. Consideramos que para que isso aconteça, é necessário que as diversas áreas curriculares, disciplinares e não disciplinares, tenham uma maior relação com o dia-a-dia dos alunos, com as novas exigências da sociedade contemporânea e se preocupem com a formação do novo cidadão, núcleo fundamental do tecido de que se fazem as sociedades. É igualmente fundamental que se recuse a educação promotora da uniformização, da massificação, da normalização, mas que estimule a criatividade e a diferença. Assim, a educação contemporânea não se pode reduzir a uma mera transmissão de conhecimentos, a um cognitivismo mecanicista, alheio a conteúdos éticos ou valorativos. Educar o ser humano não é só fornecer e transmitir conhecimentos, é dar os meios suficientes para a construção da sua autonomia e da sua identidade. 0 futuro do ser humano não deve ser subjugado às necessidades de produção ou finalidades profissionais, às ideologias tecnocráticas, religiosas ou políticas, mas é necessário que haja a consciência que o futuro do ser humano deve ser deixado em aberto. Não existe apenas um modelo de homem como também não existe um modelo de educação. $A$ «melhor» educação poderá ser aquela que tiver mais presente o sentimento do pluralismo cultural, da diferença e do carácter plural e aberto do ser humano.

A educação e o direito à educação permitem a verdadeira relação entre o idêntico e o diferente, entre o universal e o particular. Tal finalidade implica uma filosofia da educação que não ignore nem subestime a cultura das minorias, apreciada com frequência a um nível folclórico, mas que considere explicitamente as estruturas epistemológicas e as orientações de cariz ideológico específicas. Dado que a diversidade cultural emerge como característica dominante do mundo actual, o absolutismo não pode imperar, sendo a escola o espaço onde se aprende a viver a diferença que será o estímulo para as grandes questões éticas do futuro.

De acordo com Maria Praia (1999:34), o fim último da «educação para a cidadania é alfabetizar eticamente a Pessoa, sendo a ética entendida não como uma metodologia normativa, mas como uma praxis fundamentadora de uma reflexão crítica». Para esta autora, a ética, entendida como um conceito que tem implícito a racionalização da conduta humana, torna emergente a clarificação de valores, a decisão racional, a acção inteli- 
gente e a problematização das axiologias normativas, ou seja, o facto de se poder pôr em questão os valores socialmente determinados. «É o primado da consciência reflexiva chamada a desempenhar uma função determinante no comportamento» (Praia, 1999: 34).

Secundando Braga da Cruz (1998:48), «educar para os valores é hoje não apenas um programa pedagógico, mas uma estratégia de reforma quer da educação quer da democracia e, com elas, de desenvolvimento da sociedade portuguesa».

As orientações da UNESCO sobre esta temática sublinham que «os valores e, em particular, a tolerância não podem ser objecto de ensino, no estrito sentido do termo: querer impor valores previamente definidos, pouco interiorizados, leva no fim de contas à sua negação, porque só têm sentido se forem livremente escolhidos pela pessoa» (Delors et al, 1996: 51). A escola pode criar condições para a prática diária da tolerância e do respeito do outro, auxiliando os alunos a ter em atenção os pontos de vista dos outros e estimulando a discussão de dilemas morais ou de situações que impliquem opções éticas.

\subsection{O papel do professor do $1 .{ }^{\circ}$ Ciclo do Ensino Básico}

Nas sociedades contemporâneas torna-se indispensável e urgente educar para a cidadania responsável. Actualmente, a responsabilidade da escola e do professor no desenvolvimento global da personalidade do aluno aumentaram. É certo que a escola é apenas uma das muitas oportunidades de formação cívica de que o aluno dispõe, mas o aumento de permanência na escola, a complexidade da preparação para a vida adulta e a aparente «desistência» por parte das famílias de assumir as suas responsabilidades na tarefa de formar a consciência social e cívica das crianças, renunciando à transmissão de aquilo que sabem em favor de um ensino dado pela escola, faz com que a instituição escolar tenha ainda mais responsabilidade nesta função educativa. Deste modo, é necessário proporcionar desde o início da escolaridade uma formação ampla e abrangente de forma a tornar os alunos, desde cedo, intervenientes no espaço social envolvente. Concordamos com Leite e Rodrigues (2001: 23) quando afirmam que «quanto mais precocemente estas atitudes de solidariedade activa forem adquiridas, mais facilmente se evitará a assimilação de estereótipos e de atitudes que, frequentemente, surgem associados a fenómenos como o racismo e a xenofobia». Assim, para além do desenvolvimento das competências das diversas áreas curriculares disciplinares é necessário promover a aceitação activa da diversidade 
e a aquisição e o desenvolvimento de competências cívicas. Em alguns casos, a educação continua a desenvolver-se na sua forma tradicional, tendo como finalidade a adaptação da pessoa à sociedade tal como ela existe, com vista à sua estabilidade. No entanto, com este procedimento retira-se ao ser humano a liberdade de pensamento.

Num momento em que o futuro é um desafio para todos, cabe ao professor um papel fundamental na mediação das trocas entre o aluno e o meio social, cultural e físico envolvente de modo a possibilitar ao aluno utilizar todas as suas oportunidades de acesso à cultura do seu e de outros grupos, mostrando-lhe tudo aquilo de que dispõe para aprender. Estas experiências educativas deverão ter lugar numa atmosfera de questionabilidade que conduza professores e alunos à tomada de consciência de si próprio, potencializando as suas capacidades para o entendimento e para a acção.

Educar é sempre um processo renovado e adaptado às circunstâncias concretas da época (sociais, culturais, éticas, políticas, económicas, ideológicas e científicas), às condições que a própria escola proporciona, ao seu meio envolvente, ao contexto escolar e à realidade, vivências e características dos alunos. Por outro lado, é difícil para o professor educar de uma forma completamente neutra, pois a sua prática reflecte sempre os valores que adoptou, as suas vivências, as suas convicções e a sua representação do futuro desejável.

No 1. ${ }^{\circ}$ CEB, cabe ao professor titular da turma a responsabilidade de delinear, organizar e desenvolver as estratégias e as actividades mais apropriadas à implementação da área curricular não disciplinar denominada como área de Formação Cívica. No entanto, uma perspectiva mais ampla e dinâmica do desenvolvimento desta área pode ser assumida nas opções a tomar ao nível do projecto educativo e curricular da escola. Esta área torna-se espaço adequado para promover o desenvolvimento efectivo de uma maturidade cívica, dando destaque à importância da relação interpessoal professor - aluno, para o desenvolvimento de práticas pedagógicas incitadoras da aceitação activa da diversidade e para o desenvolvimento de processos de aprendizagem para o exercício da cidadania. O professor poderá atingir estes objectivos ao realizar actividades de reflexão e de estudo que ajudem ao aluno adquirir as competências que the permite participar na vida do meio que o rodeia, ao mesmo tempo que the facilita obter uma melhor compreensão desse meio envolvente. Para Fonseca (2002:24), «o civismo (reflectido e agido) deve surgir como a questão central a ser abordada neste espaço curricular próprio, destacando a relação entre um eu cívico e um nós social através do sentido de 
responsabilidade, do espírito crítico, do gosto pela participação e do empenhamento na vida colectiva».

Por outro lado, e dado o seu carácter transversal, a educação para a cidadania poderá ser concretizada através da disseminação dos seus objectivos pelas várias áreas curriculares, que constitui uma oportunidade para integrar a formação cívica dos alunos na formação global propiciada pelo contexto escolar.

Alguns autores (Fonseca, 2002; Leite e Rodrigues, 2001) consideram que o trabalho pedagógico no âmbito da educação para a cidadania será ainda mais válido quanto mais estiver integrado no currículo e quanto menos for encarado como uma disciplina adicional. Assim, para Leite e Rodrigues (2001: 25), em termos de organização curricular, a educação para a cidadania «deverá ser uma área temática que atravesse todas as disciplinas, não fazendo sentido a sua aglutinação em mais uma disciplina, como se de um conteúdo se tratasse».

No 1. ${ }^{\circ}$ CEB, a existência de um currículo verdadeiramente aberto à transdisciplinaridade possibilita a integração de outros conteúdos para além dos que já estão predefinidos e a emergência de novas práticas de trabalho não condicionadas pela rigidez em termos de horários, como sucede nos outros ciclos do ensino básico. O professor pode utilizar esta formação transversal para promover o estreitamento das ligações entre a comunidade e a escola, possibilitando a vivência de situações e contactos significativos, que constituem momentos de aprendizagem proveitosos para o desenvolvimento de competências de cidadania. Pode utilizar igualmente a formação transversal da educação para a cidadania para desenvolver projectos de natureza interdisciplinar, onde se prevejam momentos de acção e momentos de reflexão pessoal. Cabe assim ao professor a importante tarefa da escolha dos melhores métodos e processos a seguir na educação para a cidadania, tendo sempre presente que «é necessário educar na cidadania pela cidadania, ou seja, para a liberdade pela liberdade e com responsabilidade» (Figueiredo, 1999:88)

A cidadania não se impõe mas constrói-se, organizando-se e assumindo- se como uma tarefa de formação cívica que o professor deve considerar - próprio cerne da educação, pois esta tarefa é intrínseca ao processo educativo dos seus alunos em fase de formação integral da sua personalidade, e que se pretende que sejam cidadãos responsáveis, conscientes, solidários e activos. 
A escolha de estratégias e de metodologias activas a adoptar realizada pelo professor deverá assentar na aquisição de conhecimentos e de competências ligados a realidades cívicas do quotidiano de uma sociedade democrática, no sentido de estimular a autonomia, a responsabilidade e a solidariedade dos alunos.

Para o professor é desejável este equilíbrio entre conhecimento e competências na medida em que se torna necessária uma relação de complementaridade entre teoria e prática. Pensamos que não existe qualquer utilidade em transmitir e desenvolver valores morais e cívicos se não criarmos oportunidades para que as crianças possam exercitá-los e possam avaliar as respectivas consequências para si e para a comunidade envolvente.

Consideramos ainda que o docente tem um papel essencial neste processo através das suas práticas, daquilo que comunica, dos seus exemplos, do modo como resolve conflitos, da forma participativa como organiza o processo de ensino/aprendizagem, da maneira como estimula, recebe, valoriza e faz compartilhar os saberes dos alunos e da forma como os consegue utilizar como elemento pedagógico no processo educativo.

O professor da escola contemporânea deverá ter sempre presente que o objectivo da educação para a cidadania adequada aos nossos dias passará por ligar os alunos às realidades de natureza cívica com as quais se vejam confrontados a nível local, nacional ou global. Tendo sempre presente a necessidade de aproximar-se das realidades e das vivências significativas do dia-a-dia, que mais directamente tocam a vida das pessoas, é que o professor poderá conduzir as crianças no sentido da compreensão do que é ser cidadão e da determinação do modelo de sociedade que desejam para o futuro que lhes pertence.

Secundamos António Fonseca (2000:22) quando afirma que «a educação cívica deverá consistir, acima de tudo, em fazer as pessoas conscientes da realidade vivida pelos semelhantes, ou seja, aprender a ver a vida e as coisas com olhos humanos». No entanto, e para que tal aconteça, o professor na sua acção educativa deve possibilitar ao aluno o contacto com diferentes modelos de pensamento e de comportamento cívico, incentivando-o a fazer as suas próprias escolhas, as quais representam e exprimem desejos, necessidades e aspirações do aluno. 0 que aqui se valoriza é que o desenvolvimento do aluno, enquanto entidade cívica, seja algo de edificante e progressivo e não algo imposto do exterior. Neste processo, o professor tem um papel relevante, pois não convém que percorra 
o trilho do aluno, que não the ofereça ou indique as respostas previamente, mas é fundamental que o auxilie a obter uma compreensão da sua existência, a consciencializar-se como alguém que possui certas características próprias e que atribui um sentido específico às realidades e experiências do seu quotidiano.

Desta forma, «o exercício da cidadania será uma consequência natural e lógica desse sentido que é dado às coisas da vida e à própria vida, ultrapassando as forças do egocentrismo para reconhecer o outro social e manifestando um eu cívico simultaneamente enraizado no solo da tradição a que se pertence e aberto aos novos espaços de intervenção que a evolução humana permanentemente suscita» (Fonseca, 2000:24).

Para a promoção de uma educação para a cidadania democrática e activa é necessário que a própria instituição escolar se torne num local privilegiado de participação e de educação para a participação, uma escola democrática para todos, aberta à diversidade e promotora de uma educação multicultural. Um dos pressupostos fundamentais para que exista uma atmosfera democrática na sala de aula e na escola «é o reconhecimento de que o professor não está ali para julgar os sentimentos e valores das pessoas mas para ajudar a discussão e a partilha aberta das ideias sobre questões éticas e cívicas» (Marques, 1992: 87).

Esta escola não deve apenas transmitir conhecimentos, mas preocupar-se igualmente com a formação global dos alunos, numa perspectiva onde o conhecer e o intervir na realidade se encontrem. Porém, para que tal aconteça, é necessário saber conviver e trabalhar com as diferenças, reconhecê-las e aceitar que para cada um se conhecer melhor a si próprio precisa conhecer e comunicar com os outros que o rodeiam. Neste contexto, os professores necessitam promover o entendimento e a comunicação intercultural entre os diferentes alunos, transformando a escola num espaço de convivência, onde em vez de se dissimularem os conflitos, estes são reconhecidos e trabalhados. É fundamental que os docentes possam contribuir para a autonomia dos seus alunos, defendendo a prática do diálogo, da discussão e da resolução de conflitos, que ajudem os alunos a participar na vida das escolas, num clima de respeito, dignidade, diálogo e solidariedade. É igualmente importante que os docentes, para além do seu envolvimento na promoção da construção social dos valores dos alunos, se apercebam da importância da vivência organizacional e do clima e cultura de escola e das oportunidades de desenvolver experiencialmente intervenções e práticas em contexto democrático. No entanto, para que a escola se possa assumir como espaço de educação, de participação e de cidadania democrática é essencial que esta pro- 
mova o exercício activo e crítico da cidadania através do envolvimento consciente e crítico dos seus professores e da prática de uma pedagogia de autonomia orientada para a formação de futuros cidadãos, capazes de analisar a realidade, formular juízos, tomar as suas próprias decisões, implicar-se activamente na vida social, sempre de modo responsável e consciente.

A valorização do envolvimento e da participação activa na comunidade, por parte do professor, é uma dimensão da educação para a cidadania que consideramos fundamental no desenvolvimento de uma identidade cívica dos alunos. Concordamos com Fonseca (2002:20) quando defende que a formação de «cidadãos responsáveis e participativos pressupõe a construção simultânea de uma identidade social (fundamentada no respeito pelos direitos e deveres da pessoa humanal e de uma maturidade cívica laqui entendida como a aquisição e a adopção consciente de valores, atitudes e comportamentos que sustentam o funcionamento das sociedades democráticas), desempenhando a instituição escolar um papel determinante no que respeita à transmissão de conhecimentos sobre as instituições sociais e politicas e ao desenvolvimento de hábitos de participação nos grupos e instituições da comunidade». Para que mais tarde o aluno valorize essa colaboração na vida dessas instituições, é essencial que já na escola ele descubra a importância e utilidade dessa actividade com proveito para o bem da comunidade, é ainda fundamental valorizar o papel dos alunos como membros da comunidade escolar, atribuindo significado às formas de participação. Para além disso, investir no desenvolvimento das competências de debate de ideias e de tomada de decisões poderá reforçar a responsabilidade, a capacidade de ter poder de decisão e fortalecer o sentimento de pertença.

Consideramos ainda que é indispensável que o docente estimule uma maior aproximação entre a instituição escolar e o meio envolvente, de modo a promover uma ligação entre os alunos e as realidades de natureza cívica com as quais se vejam confrontados, a nível local, nacional e até global. Esta abertura da escola à realidade do meio envolvente constitui uma forma de facilitar as aprendizagens e de as tornar mais significativas. 0 envolvimento dos alunos em actividades de ligação com o meio, para além dos benefícios específicos de aprendizagens relevantes no âmbito de cidadania, contraria o aparecimento de tendências egocêntricas e a emergência de formas de exclusão e discriminação.

Pensamos que pelo que foi analisado anteriormente podemos concluir que no âmbito da prática pedagógica do $1 .{ }^{\circ} \mathrm{CEB}$, o ensino unicamente teórico dos direitos e deveres sociais tem um interesse um pouco limitado 
para a vida futura dos alunos, sendo essencial valorizar questões centrais da vida humana, as experiências significativas actuais, o papel e a implicação pessoal do aluno na construção da sociedade, os conflitos da sociedade do presente e os desafios de carácter social e pessoal que se colocam aos alunos numa perspectiva de um futuro próximo. Para isso, a escola e os professores deverão ver os alunos como indivíduos activos, empenhando-se em experimentar percursos pedagógicos que promovam essa actividade, estimulem a reflexão sobre o que os rodeia e sobre si próprios, incitem os contactos com o que é diferente, desafiem dogmas criados e desenvolvam uma consciência moral autónoma.

No que diz respeito à formação de professores, são relativamente poucos os que possuem uma formação específica para a educação para a cidadania. É necessário que o docente esteja consciente e evite que a sua acção educativa não fique restringida aos efeitos redutores do senso comum e que este não seja tentado a conceber o seu currículo nesta área, muito particular e pessoal, apesar de se considerar que as opções decorrerão sempre de modelos auto-elegíveis. Para o professor, educar para a cidadania pode ser um desafio, pois pode implicar o abandono de algumas certezas e até de crenças e valores, que não necessariamente de princípios referenciais de vida. É necessário estar-se conscientemente alerta para o facto de que a realidade se desenrola em contextos diversos, podendo alguns deles não oferecer as condições ideais para a aplicação dos nossos princípios, o que nos exige flexibilidade, receptividade à mudança, uma postura dialéctica e até pode induzir uma redescoberta de nós mesmos como cidadãos e como pessoas. Consideramos que educar para a cidadania exige uma formação adequada de professores la nível de formação inicial e a nível de formação contínual, pois, por vezes, existem situações em que a prática, só por si, não é suficiente para confrontar a realidade e é preciso uma fundamentação teórica mínima de apoio para obter uma prática efectiva e válida, pela qual se opta intencionalmente. 


\section{CAPÍTULO III - ANÁLISE DA CIDADANIA A PARTIR DE LEGISLAC̣ÃO E DOCUMENTOS ORIENTADORES}

\section{NOTAS INTRODUTÓRIAS}

Actualmente, a relação entre a escola e a cidadania é bastante valorizada pelas instâncias governativas no âmbito das políticas educativas. É objectivo principal da escola assegurar a formação integral dos alunos devendo para isso assumir-se «como um espaço privilegiado de educação para a cidadania e de integrar e articular, na sua oferta curricular, experiências de aprendizagem diversificadas nomeadamente mais espaços de efectivo envolvimento dos alunos e actividades de apoio ao estudo» (Abrantes, 2001:36).

Assim, consideramos relevante e pertinente analisar neste capítulo de que forma se aborda a questão da cidadania e a importância da educação para a cidadania democrática no sistema de ensino a nível institucional. Para isso iremos tentar apurar quais as respostas institucionais patentes na legislação, nos documentos orientadores das políticas educativas e no currículo enunciado do $1 .{ }^{\circ}$ CEB para este desafio do desenvolvimento de uma cidadania democrática nas escolas portuguesas. Analisaremos ainda algumas orientações a nível internacional para a educação para a cidadania.

\section{O DISCURSO EXPRESSO NA CONSTITUIÇÃO DA REPÚBLICA}

Iniciamos esta análise abordando o discurso expresso na Constituição da República Portuguesa de 1976 dado que neste documento é já visível um interesse acentuado por questões de cidadania democrática, manifestando uma posição contrária à do período de vigência do Estado Novo, antes do 25 de Abril de 1974. «Antes do 25 de Abril, toda a matriz do sistema educativo censurava a liberdade, a autonomia, a equidade e a participação, e inculcava o medo, o fechamento, a obediência passiva e a submissão (...). A educação cívica da ditadura era, propriamente uma propaganda moral, religiosa e ideológica reaccionária, hostil a tudo o que representasse modernidade, inovação, pluralismo e espírito crítico». (Figueiredo, 1999:43).

A Constituição da República Portuguesa de 1976 consagrou finalmente no nosso país os princípios da Declaração Universal dos Direitos do Homem e «consignou princípios respeitantes ao ensino e à educação e que preconizavam a liberdade de aprender e de ensinar, o direito de todos 
à educação e à cultura, o direito ao ensino com garantia de igualdade de oportunidades de acesso e sucesso escolares» (Leite e Terrasêca, 1995:40), expressos nos artigos 43. ${ }^{\circ}$ (liberdade de aprender e ensinar), 73. ${ }^{\circ}$ (educação e cultura) e $74 .^{\circ}$ (ensino) da Constituição.

É de salientar a importância destes princípios que foram mantidos nos artigos $43 .{ }^{\circ}, 73 .{ }^{\circ}$ e $74 .{ }^{\circ}$, apesar de pequenas alterações do texto resultantes das sucessivas revisões constitucionais em 1982, 1989, 1992 e 1997. Após esta última revisão constitucional em 1997, o texto constitucional relativo aos artigos acima referidos é o seguinte:

Art. ${ }^{\circ} 43 .{ }^{\circ}-$ (Liberdade de aprender e ensinar)

1. É garantida a liberdade de aprender e ensinar.

2. O Estado não pode programar a educação e a cultura segundo quaisquer directrizes filosóficas, estéticas, políticas, ideológicas ou religiosas.

3. O ensino público não será confessional.

4. É garantido o direito de criação de escolas particulares e cooperativas.

Art. ${ }^{0} 73 .^{\circ}$ - (Educação, cultura e ciência)

1. Todos têm direito à educação e à cultura.

2. O Estado promove a democratização da educação e as demais condições para que a educação, realizada através da escola e de outros meios formativos, contribua para a igualdade de oportunidades, a superação das desigualdades económicas, sociais e culturais, o desenvolvimento da personalidade e do espírito de tolerância, de compreensão mútua, de solidariedade e de responsabilidade, para o progresso social e para a participação democrática na vida colectiva.

3. O Estado promove a democratização da cultura, incentivando e assegurando o acesso de todos os cidadãos à fruição e criação cultural, em colaboração com os órgãos de comunicação social, as associações e fundações de fins culturais, as colectividades de cultura e recreio, as associações de defesa do património cultural, as organizações de moradores e outros agentes culturais.

4. A criação e a investigação científicas, bem como a inovação tecnológica, são incentivadas e apoiadas pelo Estado, por forma a assegurar a respectiva liberdade e autonomia, o reforço da 
competitividade e a articulação entre as instituições científicas e as empresas.

Art. ${ }^{0} 74 .^{\circ}-($ Ensino $)$

1. Todos têm direito ao ensino com garantia do direito à igualdade de oportunidades de acesso e êxito escolar.

2. Na realização da política de ensino incumbe ao Estado:

a) Assegurar o ensino básico universal, obrigatório e gratuito;

b) Criar um sistema e desenvolver o sistema geral de educação pré-escolar;

c) Garantir a educação permanente e eliminar o analfabetismo;

d) Garantir a todos os cidadãos, segundo as suas capacidades, o acesso aos graus mais elevados do ensino, da investigação científica e da criação artística;

e) Estabelecer progressivamente a gratuidade de todos os graus de ensino;

f) Inserir as escolas nas comunidades que servem e estabelecer a interligação do ensino e das actividades económicas, sociais e culturais;

g) Promover e apoiar o acesso dos cidadãos portadores de deficiência ao ensino e apoiar o ensino especial, quando necessário;

h) Proteger e valorizar a língua gestual portuguesa, enquanto expressão cultural e instrumento de acesso à educação e da igualdade de oportunidades;

i) Assegurar aos filhos dos emigrantes o ensino da língua portuguesa e o acesso à cultura portuguesa;

j) Assegurar aos filhos dos imigrantes apoio adequado para efectivação do direito ao ensino.

Convém realçar o aditamento da alínea j) do n. ${ }^{\circ} 2$ que acompanha a realidade actual do nosso país no que diz respeito à crescente mobilidade das populações e ao afluxo a Portugal de cidadãos vindos de outros países. 


\section{A LEI DE BASES DO SISTEMA EDUCATIVO}

A filosofia da Lei de Bases do Sistema Educativo inspira-se em «princípios democráticos, tais como a liberdade de ensino, a provisão pública de serviços, a igualdade de oportunidades, a equidade, a laicidade, a livre participação» (Silva e Figueiredo, 1999:32). A sua implementação realizou-se entre 1989 e 1994, numa dinâmica de reforma do sistema. A escola foi «objecto de uma mudança profunda, comandada do centro, isto é, pelas autoridades governamentais, e muito focalizada na produção legislativa e na revisão curricular» (ibidem).

A Lei de Bases do Sistema Educativo (Lei n. ${ }^{\circ} 46 / 86$ ) aprovada na Assembleia da República, orienta-se por preocupações relacionadas com a questão da educação para a cidadania e de reconhecimento de pluralismo cultural, apontando para uma educação cívica promotora da compreensão de alguns valores básicos tais como a tolerância, os direitos humanos e a liberdade, assim como o desenvolvimento integral dos alunos.

A Lei de Bases do Sistema Educativo começa por afirmar que «todos os portugueses têm direito à educação e à cultura, nos termos da Constituição da República» (art. ${ }^{\circ} 2 .{ }^{\circ},{ }^{\circ}{ }^{\circ} 1$ ), assumindo que «é da especial responsabilidade do Estado promover a democratização do ensino, garantindo o direito a uma justa e efectiva igualdade de oportunidades no acesso e sucesso escolares» (art. ${ }^{\circ} 2 .^{\circ}$, n. $^{\circ}$ 2).

A preocupação com a preparação dos alunos para a cidadania democrática é evidente na Lei de Bases do Sistema Educativo, na qual surge como um dos objectivos finais da educação, envolvendo o próprio funcionamento da instituição escolar enquanto organização democrática.

Na Lei de Bases do Sistema Educativo existem referências à educação para a cidadania quando considera que o sistema educativo contribui «(..) para o desenvolvimento pleno e harmonioso da personalidade dos indivíduos, incentivando a formação de cidadãos livres, responsáveis, autónomos e solidários (...)» (art. ${ }^{\circ} 2 .^{\circ},{ }^{\circ} .^{\circ}{ }^{4}$ ) e que «a educação promove o desenvolvimento do espírito democrático e pluralista, respeitador dos outros e das suas ideias, aberto ao diálogo e à livre troca de opiniões, formando cidadãos capazes de julgarem com espírito crítico e criativo o meio social em que se integram e de se empenharem na sua transformação progressiva» (art. ${ }^{0} 2 .^{\circ}$, n. $^{0}{ }^{5}$ ). Este último ponto, para além de fazer referência directa à formação de cidadãos tem também subjacente «o princípio de interacção e comunicação entre grupos» (Leite, 2002:303), 
- qual consideramos fundamental para a harmoniosa convivência na sociedade actual.

A lei salienta ainda que o sistema educativo se organiza de modo a «contribuir para a realização do educando, através do pleno desenvolvimento da personalidade, da formação do carácter e da cidadania, preparando-o para uma reflexão consciente sobre os valores espirituais, estéticos, morais e cívicos (...)» (art. ${ }^{\circ} .^{\circ}$, alínea b).

A referida lei define como objectivos do ensino básico «proporcionar aos alunos experiências que favoreçam a sua maturidade cívica e sócio-afectiva, criando neles atitudes e hábitos positivos de relação e cooperação, quer no plano dos seus vínculos de família, quer no da intervenção consciente e responsável na realidade circundante» (art. ${ }^{7} .^{\circ}$, alínea h) e «proporcionar a aquisição de atitudes autónomas, visando a formação de cidadãos civicamente responsáveis e democraticamente intervenientes na vida comunitária» (art. ${ }^{7} .^{\circ}$, alínea i).

Para concluir esta análise, é importante referir que nos objectivos expressos para o ensino básico na Lei de Bases do Sistema Educativo podemos encontrar valores associados à liberdade, espírito crítico, criatividade, cooperação, solidariedade social, identidade nacional, dimensão humana do trabalho e intervencão democrática na vida comunitária. Surge-nos também como princípios fundamentais o desenvolvimento pessoal, social e moral dos alunos e a promoção da educação moral e cívica em liberdade de consciência.

\section{A REFORMA DO SISTEMA EDUCATVO}

Para além dos desafios lançados pela Lei de Bases do Sistema Educativo de 1986 também a Revisão Curricular de 1989 expressa a necessidade de uma escola centrada na construção de uma cidadania democrática.

No Decreto-Lei n. ${ }^{\circ} 286 / 89$, que estabelece os planos curriculares da reforma do ensino básico e ensino secundário está perceptível a preocupação com os valores democráticos na instituição escolar e o desenvolvimento de atitudes de autonomia pessoal e de solidariedade, atitudes de cooperação e hábitos de trabalho, respeito pelo trabalho dos colegas e disponibilidade para a entreajuda.

No âmbito da Reforma do Sistema Educativo salientamos que o sistema educacional tem como objectivos estimular «o desenvolvimento de capa- 
cidades cognitivas, motoras e relacionais das crianças, adolescentes e jovens, promovendo a realização individual em harmonia com os valores da solidariedade, da liberdade social; assegurar a formação cívica e moral das jovens gerações, no respeito e valorização das diferentes personalidades, projectos individuais de existência, valores e culturas (...); garantir a igualdade de oportunidades de acesso à cultura e ao usufruto de bens educacionais e promover a integração social e a valorização das pessoas na comunidade local, regional, nacional e europeia» (Ministério da Educação, 1992:7 e 8).

Enuncia-se ainda que a escola deixou de visar apenas a transmissão de conhecimentos para privilegiar também o «desenvolvimento de atitudes de autonomia pessoal e de solidariedade, hábitos de trabalho e atitudes de cooperação; respeito pelo trabalho dos colegas e disponibilidade para a entreajuda» (idem:36).

No âmbito da revisão curricular pode-se constatar uma crescente importância dos objectivos afectivos e de atitudes sobre os puramente cognitivos. Assim, uma das implicações da concepção da aprendizagem é a de tratar todos os alunos com igualdade, de modo a dar a todos oportunidades iguais, visando que todos alcancem os objectivos estabelecidos. Com esta revisão, a questão da formação e da prática democrática e cívica não foram esquecidas, confirmando-se a importância da cidadania democrática na educação. No quadro dos novos planos curriculares, «foi introduzida, em todo o ensino uma área disciplinar não disciplinar chamada Área - Escola lárea superior de formação interdisciplinarl destinada a acolher projectos de natureza interdisciplinar, centrados no desenvolvimento moral e social das crianças e adolescentes (...) e explorando as ligações da escola ao seu meio ambiente» (Silva e Figueiredo, 1999:32). Nesta perspectiva, «a abordagem dos temas/problemas não deveria fazer-se um plano meramente académico e formal, mas também abordando dimensões pessoais e afectivas, envolvendo os alunos em práticas e acções concretas num plano local (conhecimento da comunidade) e global (cidadania europeia)» (idem:36).

No Decreto-Lei n. ${ }^{\circ}$ 286/89, a Área - Escola era considerada como espaço privilegiado previsto para a formação para a cidadania e os seus objectivos procuravam a «concretização de saberes através de actividades e de projectos multidisciplinares, entre a escola e o meio e a formação pessoal e social dos alunos» (art. ${ }^{0}$ 6..$^{\circ}$, n. $^{\circ}$ 2). Nesta área - escola estava presente a educação para a cidadania na medida em que tentava aliar o domínio cognitivo, afectivo e acção. 
No âmbito desta revisão chegou a ser aprovado um programa de educação cívica (art. ${ }^{0} 7 .{ }^{\circ}$, n. ${ }^{0}$ 3) para a participação nas instituições democráticas, obrigatório para o $3 .^{\circ}$ ciclo do Ensino Básico, incluído na Área- Escola. O desenvolvimento do programa deveria ser realizado através de actividades de carácter cívico e do trabalho de projecto. Porém, o programa foi divulgado em apenas 6 escolas (em 1991/92), acabando por não ter continuação.

0 texto do Decreto-Lei n. ${ }^{0}$ 286/89 também afirma que todas as componentes curriculares «devem contribuir de forma sistemática para a formação pessoal e social dos educandos favorecendo, de acordo com as várias fases de desenvolvimento, a aquisição do espírito crítico e a interiorização de valores espirituais, estéticos, morais e cívicos» (art. ${ }^{0} 7 .^{\circ}$, n. $^{\circ} 1$ ) e concretiza-se na disciplina de Desenvolvimento Pessoal e Social, alternativa opcional à Educação Moral e Religiosa.

Deste modo, foi implementada a disciplina de Desenvolvimento Pessoal e Social obrigatória para os alunos do Ensino Básico que não optassem por frequentar a disciplina de Religião e Moral católica lou de outra religião), e desde que as escolas tivessem condições para a oferecer, dizendo o Decreto-Lei que «em alternativa à disciplina de Desenvolvimento Pessoal e Social os alunos poderão optar pela Disciplina de Educação Moral e Religião Católica ou de outras confissões» (art. ${ }^{0}$ 7. ${ }^{\circ}$, n. ${ }^{0} 4$ 4).

A Formação Pessoal e Social é entendida como formação transdisciplinar a par da «valorização da dimensão humana do trabalho e o domínio da língua materna» (art. ${ }^{\circ} 9 .{ }^{\circ}$, n. ${ }^{\circ} 1$ ) e nela concretizam-se as matérias enunciadas no n. ${ }^{\circ}$ do art. ${ }^{\circ} 47 .{ }^{\circ}$ da Lei de Bases do Sistema Educativo leducação ecológica, educação do consumidor, educação familiar, educação sexual, a prevenção de acidentes, a educação para a saúde, a educação para a participação nas instituições, serviços cívicos e outros do mesmo âmbito). No entanto, foram poucas as escolas do Ensino Básico que conseguiram implementar esta disciplina.

Ainda no âmbito da reforma, foram lançados programas de promoção do sucesso educativo no Ensino Básico e de combate ao abandono precoce dos quais se destaca o Programa de Educação para todos e um programa de Educação Intercultural em escolas com presença significativa de comunidades étnicas de origem estrangeira. 0 regime de avaliação dos alunos foi alterado atribuindo à avaliação um papel formativo, «enunciando a intenção de que, através dela, os professores e professoras obtenham elementos para individualizarem o ensino e respeitarem as diversidades, e que os alunos sejam encorajados a ultrapassar as suas 
dificuldades» (Leite, 2002:304). Assim, é expresso no Decreto-Lei em análise que «o regime de avaliação dos alunos deve estimular o sucesso educativo de todos os alunos, favorecer a confiança própria e contemplar os vários ritmos de desenvolvimento e progressão» (art. ${ }^{\circ} 10 .{ }^{\circ}$, n. ${ }^{\circ}$ 2).

Para além das actividades curriculares foram estimuladas «actividades escolares de complemento curricular, de carácter facultativo e natureza eminentemente lúdica e cultural, visando a utilização criativa e formativa dos tempos livres dos educandos» (art. ${ }^{\circ} 8^{\circ}$, n $^{\circ}{ }^{0}$ 1). Foi criado «um subsistema de ensino recorrente, concebido como segunda oportunidade de educação para jovens e adultos, e um serviço se apoio de trabalho e orientação escolar» (Silva e Figueiredo, 1999:32).

Fazendo um balanço da Reforma, iniciada com a Lei de Bases do Sistema Educativo de 1986, do ponto de vista da educação para a cidadania, poderíamos indicar como bastante significativo o contributo ao nível da definição das finalidades do sistema e da sensibilização dos professores e das escolas para temáticas inovadoras e modos de estruturação dos processos pedagógicos e da organização escolar.

Como temos vindo a constatar nesta análise, a educação para a cidadania está presente na Revisão Curricular de 1989, principalmente através da área curricular não disciplinar, de natureza interdisciplinar da Área- Escola e na disciplina de Desenvolvimento Pessoal e Social no entanto, e de acordo com Silva e Figueiredo (idem:33) «não parece ter sido esta uma orientação central, no desenho das políticas concretas, da Reforma». Assim, apesar da importância filosófica que a Lei de Bases do Sistema Educativo conferiu à questão da cidadania e da educação para a cidadania, não houve um esforço equivalente para a concretizar. «Daí que a explicitação da 'cidadania' como um quadro de referência para as políticas educativas, em 1996 ou 1997, tenha surgido como uma novidade» (idem:34).

De qualquer modo, a Lei de Bases do Sistema Educativo de 1986 e a Revisão Curricular de 1989 evidenciam a importância da cidadania democrática dado que se entende nesses dois documentos que a escola não deve apenas promover conhecimentos dos alunos, mas também desenvolver concepções, atitudes e competências de cidadania. Os programas e manuais do ensino básico reflectem bem essa pretensão, como poderemos constatar através da análise que iremos apresentar de seguida. 


\subsection{O programa do Primeiro Ciclo do Ensino Básico}

O programa do $1 .{ }^{\circ} \mathrm{CEB}$, que decorreu da Reforma Curricular laprovado pelo Despacho n 139/ME/90 de 16 de Agosto publicado no D. R. n. ${ }^{\circ}$ 202, II Série, de 1 de Setembrol evidencia também uma preocupação com o desenvolvimento da educação para a cidadania, numa perspectiva global e independente com particular incidência para a vertente intercultural, como analisaremos em seguida lem análise neste trabalho a 2. ${ }^{a}$ edição, de Novembro de 1998) ${ }^{8}$.

Porém, a aquisição e desenvolvimento de competências de cidadania não passa apenas pela transmissão de mensagens nas aulas em que o professor apenas informa. «Estas competências adquirem-se em práticas efectivas de cidadania, dentro ou fora da sala de aula, desencadeadas por propostas que podem surgir de formas diversificadas e a partir das mais variadas situaç̃ões de vida escolares ou não escolares» (Menezes, Xavier e Cibele, 1997:12). Deste modo, o docente tem um papel fundamental neste processo através da sua postura como professor, daquilo que diz, dos exemplos, das suas práticas, da forma como resolve conflitos, do modo mais ou menos participativo como organiza o processo de ensino/aprendizagem, da maneira como estimula, acolhe, valoriza e faz partilhar os saberes dos alunos e, por último, como os utiliza como objecto pedagógico no processo educativo. Indo ao encontro de algumas opiniões já referidas no capítulo anterior, as autoras salientam ainda que «a aquisição destas competências não se restringe apenas a uma disciplina mas antes se pode desenvolver em todas as disciplinas do elenco escolar» (idem:13).

Para realizar o estudo do programa do $1^{\circ} \mathrm{CEB}$, numa perspectiva de contribuição para a formação cívica do aluno, servimo-nos sobretudo de um trabalho de Menezes, Xavier e Cibele (1997), na qual estas autoras analisam da educação cívica no ensino básico em Portugal, tomando como alvo cinco temas com muita importância para o exercício da cidadania nas sociedades actuais: a democracia, a identidade nacional, a coesão e diversidade social, a economia e os problemas locais. Iremos analisar, principalmente, a opinião das autoras relativamente a dois dos temas que se enquadram com elevada relevância no nosso estudo: a democracia e a coesão e diversidade social. Para as autoras, a análise do significado

8. Em 1998 perspectivava-se já a publicação de um documento com a definição precisa dos perfis de competências que os alunos deverão atingir em cada ciclo de escolaridade e a clarificação dos núcleos essenciais das aprendizagens a alcançar nos $1 .{ }^{\circ}, 2 .^{\circ}$ e $3 .{ }^{\circ}$ ciclos. Este documento será analisado no ponto 5.1. deste capítulo. 
da democracia no contexto nacional envolve a exploração do próprio conceito e dos direitos e deveres (políticos, sociais e económicos, ...) e das instituições políticas associadas, enquanto a questão da coesão e diversidade social inclui as concepções sobre grupos discriminados (definidos em função da etnia, raça, estatuto de imigrante, língua materna, classe social, religião ou génerol e diz respeito não só à identificação desses grupos, mas também à consideração das formas de exercício dessa discriminação, o reconhecimento ou não da sua actualidade e as propostas de resolução deste problema.

\subsubsection{A democracia}

O papel da escola na abordagem da cidadania e na capacitação para - exercício de uma cidadania democrática é extremamente importante e fundamental dado que o nosso país tem uma experiência democrática recente, a sua população caracteriza-se por um nível de desenvolvimento e cultura políticos ainda frágil e existe algum desconhecimento em relação ao funcionamento e processo das instituições democráticas.

Como já referimos anteriormente, a Lei de Bases do Sistema Educativo e a Reforma Curricular «salientam esta dimensão da educação escolar, considerando, ainda, que não se trata apenas de promover os conhecimentos dos alunos, ou seja, de uma questão de carácter eminentemente cognitivo ou intelectual mas também de desenvolver atitudes, concepções e competências neste domínio. Adicionalmente, também se enfatiza o papel da estrutura e organização das escolas, sublinhando a relevância da prática da democracia na vida escolar» (Menezes, Xavier e Cibele, 1997:29)

No contexto destes documentos, a educação para a cidadania deve chegar à sala de aula, onde os alunos devem participar na elaboração das regras desse espaço. Deve aí existir uma vivência democrática em vários aspectos: participação nas tarefas, interacção entre professores e alunos, abordagem e debate de temas, oportunidade de manifestar opiniões, atitudes de tolerância, direito à diferença, ênfase no desenvolvimento pessoal e social e papel formativo e activo da escola.

Os programas do $1 .^{\circ} \mathrm{CEB}$ implicam que o desenvolvimento da educação escolar «constitua uma oportunidade para que os alunos realizem experiências de aprendizagem activas, significativas, diversificadas, integradas e socializadoras que garantam efectivamente o direito ao sucesso escolar de cada aluno» (DEB, 1998:29). 
As aprendizagens socializadoras são as que, devido às suas formas de organização escolar «contribuem para o exercício das trocas culturais, da circulação partilhada de informação e da criação de hábitos de interajuda em todas as actividades educativas. Os métodos e as técnicas a utilizar no processo de aprendizagem hão-de, por conseguinte, reproduzir as formas de autonomia e de solidariedade que a educação democrática exige» (idem:30).

De acordo com Carlinda Leite (2002:307), as aprendizagens activas, significativas e diversificadas são aquelas que mais contribuem para a «aceitação da diversidade cultural», enquanto as aprendizagens integradas e socializadoras são as que mais contribuem para uma «educação intercultural anti-racista».

De um modo geral, através do desenvolvimento dos programas propostos visa-se favorecer a aquisição de atitudes de justiça, solidariedade, tolerância e espírito crítico.

Na área de Estudo do Meio enfatiza-se a importância da participação dos alunos na organização do ambiente na turma e na elaboração de regras, desenvolvendo, ao mesmo tempo «atitudes e valores relacionados com a responsabilidade, tolerância, solidariedade, cooperação, respeito pelas diferenças, comportamento não sexista, etc.» (DEB, 1998:116). Nesta área são propostos como temas: a análise de várias instituições, incluindo a própria escola; o conhecimento dos direitos e deveres dos alunos, professores e outros profissionais; a diferenciação entre direitos individuais e direitos colectivos; o aprofundamento de formas de resolução de conflitos através do diálogo, consenso e votação.

Consideramos importante salientar um dos objectivos gerais desta área que aponta para que o desenvolvimento do processo ensino/aprendizagem permita à criança «reconhecer e valorizar o seu património histórico e cultural e desenvolver o respeito por outros povos e culturas rejeitando qualquer tipo de discriminação» (idem:110) o que pensamos que vai contribuir para a formação de cidadãos solidários e conscientes da diversidade cultural que os rodeia na sociedade democrática actual.

Na área da Língua Portuguesa destaca-se o desenvolvimento de competências de linguagem que podem ser fundamentais para a aquisição da cidadania, pelos conteúdos (como por exemplo, estabelecer correspondência com autarquias) e também pelas estratégias (participar em debates) que são sugeridas. Existe ainda a preocupação de promover a aquisição de competências instrumentais para a participação cívica 
(como por exemplo, expor e justificar opiniões pessoais, pedir esclarecimentos, informar, aguardar a vez de falar, ouvir e respeitar a fala dos outros e intervir oportunamente).

\subsubsection{A identidade nacional}

No $1 .{ }^{\circ}$ CEB, os currículos realçam o reconhecimento e a valorização do património histórico e cultural do país, com especial atenção à Língua Portuguesa, bem como o respeito por outras pessoas e culturas. A relevância é dada à importância local das personalidades e acontecimentos históricos: os alunos devem colocar datas, figuras, factos, vestígios e património da história local, personalidades nacionais com relevância no meio próximo e símbolos e regionais. Os factos históricos com relevância nacional e o seu significado são explorados a propósito dos feriados nacionais. Só no $4 .^{\circ}$ ano de escolaridade se faz referência aos símbolos nacionais (a bandeira e o hino nacional) e ao reconhecimento, em mapas, das fronteiras nacionais e dos países lusófonos.

\subsubsection{A coesão e diversidade social}

Esta questão é de extrema relevância no contexto nacional pois verificou-se, nas últimas décadas, em Portugal, uma transição significativa de um estatuto de país de emigração para país de imigração (Ramos, 1995, 2005). O fenómeno da imigração e da presença de grupos minoritários pode ter contribuído para aumentar a intensidade e gravidade de episódios racistas, no entanto «têm-se mantido mais ou menos incólumes as teorias ingénuas que assumem a tolerância como traço do "carácter nacional'; ora, estas teorias não tinham tido, até recentemente, o desafio do confronto com a prática, isto é, a interacção quotidiana com grupos diferentes quanto à etnia, religião ou estatuto de imigrante» (Menezes, Xavier e Cibele, 1997:411.

Relativamente aos programas para o $1 .{ }^{\circ} \mathrm{CEB}$, o currículo expressa o respeito por outras pessoas e culturas e a rejeição de qualquer tipo de discriminação, assim como o conhecimento de dimensões da cultura (costumes, língua, música, gastronomia, ...) dos grupos minoritários existentes na comunidade do aluno, a propósito das suas próprias vivências (no $3{ }^{\circ}$ ano de escolaridade). Mesmo quando a comunidade em que o aluno se caracteriza por alguma uniformidade cultural, este último objectivo não deve ser esquecido nem secundarizado, pois contribui para o desenvolvimento de atitudes e valores relacionados com a tolerância, solidariedade, cooperação, respeito pelas diferenças e comportamento não sexista. 


\subsubsection{A economia}

Nos programas para o 1. ${ }^{\circ} \mathrm{CEB}$, a questão da economia está presente na área de Estudo do Meio, quando se acentua a importância do recibo e/ou da factura e de reconhecer algumas actividades económicas significativas a nível local (no $3 .^{\circ}$ ano de escolaridade) e reconhecer a agricultura, a pecuária, a silvicultura, a pesca, a indústria, o comércio e os serviços como actividades económicas importantes em Portugal (no $4 .^{\circ}$ ano de escolaridade).

\subsubsection{Os problemas locais}

A área de Estudo do Meio privilegia a análise da realidade próxima dos alunos no contexto das suas comunidades, desenvolvendo atitudes de respeito pela natureza e pela vida. Visa também a promoção de atitudes relacionadas com a conservação e melhoria do ambiente, o uso racional dos recursos naturais e uma participação activa e esclarecida na resolução de problemas ambientais. Existe, no currículo enunciado, «uma preocupação intencional de promover o envolvimento dos alunos na resolução de problemas concretos e estimular a aproximação da escola à comunidade envolvente» (Menezes, Xavier e Cibele, 1997:53).

Deste modo, o programa do $3 .^{\circ}$ ano considera que os alunos devem identificar os problemas específicos da sua comunidade e cooperar no sentido de os resolver, e indica alguns tópicos que apenas serão abordados quando forem significativos a nível local, como por exemplo, a agricultura, criação de gado, exploração florestal, actividade piscatória, exploração mineral, indústria, turismo, construção, ... Relativamente à agricultura indica como objectivo identificar alguns perigos para o homem e para o ambiente resultantes do uso de produtos químicos, à floresta, conhecer algumas normas de prevenção de incêndios florestais, à indústria, reconhecê-la como fonte de poluição, à actividade piscatória, identificar alguns factores que podem pôr em causa as espécies aquáticas.

No $4 .^{\circ}$ ano de escolaridade, os alunos devem identificar e observar alguns factores que contribuem para a degradação do meio próximo (como por exemplo, lixeiras, indústrias poluentes, destruição do património histórico, ...), enumerar possíveis soluções e identificar e participar em formas de promoção do ambiente; devem identificar alguns efeitos da poluição do ar, da água e sonora; identificar alguns desequilíbrios ambientais provocados pela actividade humana (como por exemplo a extinção de recursos e a extinção de espécies animais e vegetais); e por último, reconhecer 
a importância das reservas e parques naturais para a preservação do equilíbrio entre a Natureza e a Sociedade.

Na área de Língua Portuguesa, é sugerido que os alunos realizem registos das actividades locais e que recolham e registem, por escrito, produções do património oral, o que pode servir para a sensibilização aos problemas locais.

As autoras citadas concluem «que à relevância social dos temas de cidadania considerados neste estudo corresponde uma preocupação intencional do currículo enunciado no sentido de envolver a educação escolar na capacitação dos alunos para conhecerem, reflectirem criticamente e tomarem posição sobre estas questões» (Menezes, Xavier e Cibele, 1997:56).

Nesta perspectiva, a educação escolar não se deve limitar à aquisição de cultura, mas deve também contribuir para o desenvolvimento global da personalidade, para a formação de cidadãos livres, responsáveis, autónomos e solidários. Como salienta Campos (1991:94), trata-se de «desenvolver o espírito democrático e pluralista, respeitador dos outros e das suas ideias, aberto ao diálogo e à livre troca de opiniões; formar cidadãos capazes de julgarem com espírito crítico e criativo o meio social em que se inserem e de se empenharem na sua transformação progressiva; proporcionar experiências que forneçam maturidade cívica e sócio-afectiva, criando hábitos práticos de relação e cooperação, quer no plano dos seus vínculos de família, quer no da intervenção consciente e responsável na realidade circundante; contribuir para a aprendizagem da utilização criativa dos tempos livres; fomentar a consciência nacional aberta à realidade concreta numa perspectiva de humanismo universalista, de solidariedade e de cooperação internacional».

\subsection{0 documento orientador das políticas para o Ensino Básico}

A cidadania democrática voltou a estar em posição de destaque nos documentos produzidos pelos governantes, nomeadamente em «Educação, Integração, Cidadania - Documento Orientador das Políticas para o Ensino Básico» (1989). Este documento tinha como objectivo lançar alicerces e definir a filosofia daquela que viria a ser a Reorganização Curricular do Ensino Básico lconsignada no Decreto-Lei n. ${ }^{0}$ 6/2001, que iremos analisar posteriormente) e sintetizou os aspectos que a organização curricular deveria considerar de forma a garantir uma consonância no percurso da escolaridade básica, num processo de clarificação das aprendizagens essenciais em cada ciclo. 
A questão da cidadania é realçada, logo no início do documento, ao afirmar que «ao Estado cabe definir orientações e metas, regular acções, apoiar iniciativas e incentivar o profissionalismo, assegurando a luta contra as desigualdades e o cumprimento do papel social e cultural da educação, bem individual e colectivo, ao serviço de cada um, de todos e da sociedade» (Ministério da Educação, 1998:5). É também acentuada a importância da educação básica ao referir que esta «constitui o começo de educação e formação ao longo da vida, imprescindível para responder aos novos desafios pessoais e sociais» (ibidem). Assim, a política educativa deve contribuir para a luta contra a exclusão escolar e social, pelas ligações entre educação - formação e trabalho, pelo carácter universalista da escola básica e pelo seu papel indiscutível na formação dos cidadãos.

Os objectivos do ensino básico aí expressos - educar, integrar, formar para a cidadania - são, de acordo com o Ministério da Educação, «simultaneamente simples de definir e muito difíceis de concretizar. Com efeito, a instrução e a educação são indissociáveis, pois as condições em que se processa a instrução são portadoras de valores e indutoras de comportamentos. (...) Não basta aprender, é necessário compreender e saber usar o que se aprende, é preciso que cada criança desenvolva todas as suas capacidades e a sua personalidade, aprendendo regras de convivência social que reforcem a sua integração e a sua autonomia» (idem:6).

0 documento refere que o rigor, a exigência e a solidariedade se aprendem a cada instante, não só nas aulas mas também fora delas, mesmo nos tempos livres, no convívio e nas regras que o orientam.

Expressa-se nesse documento que «assegurar a educação básica para todos significa também explicitar as dimensões cívicas de formação, para que a escola não se limite a reproduzir exemplos e contradições da vida social» (ibidem) e salienta-se que «a formação para a cidadania vive-se, experimenta-se, aprende-se em cada instante da vida escolar, sendo a educação cívica um dos eixos que dá sentido à integração e à utilização social dos saberes e do conhecimento» (idem:7).

De entre as novas orientações propostas para o ensino básico, sublinha- se a temática da cidadania, ao afirmar que é necessário «assegurar, em todos os ciclos, que as actividades de instrução e de educação para a cidadania se combinem de modo consistente e permanente» (idem:10).

As funções da escola básica não se reduzem à simples adição de disciplinas, «devendo antes assegurar-se a formação integral das crianças e dos 
jovens. A escola deve, assim, assumir-se como um espaço privilegiado de educação para a cidadania, integrando na sua oferta curricular actividades culturais e desportivas, de animação social e comunitária e de apoio ao estudo» (Ministério da Educação, 1998:19). No que diz respeito à organização curricular, esta deve ter, nos seus princípios, «a valorização do trabalho de projecto, quer no que diz respeito à educação tecnológica, quer quanto à educação cívica, com consagração de tempos curriculares no horário semanal dos alunos» (ibidem).

É referido também que o «ordenamento curricular nacional nos três ciclos da educação básica deve apontar expressamente para a aquisição de conhecimentos e competências que façam de cada jovem um cidadão autónomo, capaz de se adaptar e intervir eficazmente nos mais diversos contextos sociais» (idem:20). Ao longo do documento é mencionada várias vezes a necessidade da promoção da equidade educativa e do combate à exclusão, considerando que a democratização, a equidade no acesso ao saber e a qualidade do ensino são indissociáveis.

Em nossa opinião, existe uma preocupação presente neste documento para que a escola seja um espaço curricularmente renovado, um espaço onde não se esqueça a educação para a cidadania. Entre outros aspectos, salienta-se que a escola deve ter em consideração a luta contra as desigualdades e contra a exclusão escolar e social; o desenvolvimento das capacidades e da personalidade dos alunos; a importância da instrução e da educação; o rigor, a exigência e a solidariedade, as dimensões cívicas da formação; a autonomia e socialização; a valorização das actividades culturais e desportivas, de animação social e comunitária e de apoio ao estudo; e a educação cívica, com consagração de tempos curriculares no horário semanal dos alunos.

Por último, no âmbito da promoção de igualdade de oportunidades, - Ministério da Educação considera que para garantir a todos os alunos uma aprendizagem de identidade e de responsabilidade numa sociedade cada vez mais aberta, plural e multifacetada «a educação intercultural e a educação cívica deverão estar presentes em cada momento das actividades das escolas» (idem:40).

\section{A REORGANIZAC̣ÃO CURRICULAR DO ENSINO BÁSICO}

A reorganização curricular do ensino básico, instituída pelo Decreto-Lei n. ${ }^{\circ}$ 6/2001, de 18 de Janeiro representa a consumacão de um processo desenvolvido em relação aos currículos do ensino básico, nos últimos anos. 
Após a Reforma Curricular, já referida anteriormente, o Ministério da Educação, através do Departamento da Educação Básica (DEB), no ano lectivo de 1996/97, «lançou o Projecto de 'Reflexão Participada sobre os Currículos do Ensino Básico' com o propósito de contribuir para a construção de uma escola mais humana e inteligente, tendo em vista a formação e o desenvolvimento integral de todos os seus alunos e a promoção de aprendizagens realmente significativas» (Abrantes, 2001:35).

Através deste projecto pretendeu-se que se mobilizassem os docentes e as escolas e também a comunidade científica educacional e outros parceiros sociais para realizar um debate reflexivo sobre o currículo do ensino básico, suas finalidades e gestão no sentido de melhorar a eficácia e a adequação das práticas educativas. Foi um longo processo de reflexão e trabalho que procurou contribuir para a construção de uma «escola para todos» mais humana, criativa e inteligente, escola essa que visa a formação integral de todas as crianças e jovens e a promoção de aprendizagens realmente significativas. Nesta visão de escola, não basta adquirir conhecimentos, é necessário compreender e saber usar o que se aprende, assim como desenvolver o gosto por aprender e a autonomia no processo de aprendizagem.

O objectivo do Ministério da Educação não se centrava na alteração dos programas das disciplinas, mas sim na discussão sobre formas de gerir o currículo, de modo a que ele se desenvolva de uma forma mais adequada aos variados contextos de trabalho, às diferentes realidades socioculturais nas quais as escolas se integram. De todo o processo emergiu a necessidade de romper com a visão de currículo como um conjunto de normas a cumprir de forma uniforme e de apoiar o desenvolvimento de novas práticas de gestão curricular.

O Documento Orientador das Políticas para o Ensino Básico, publicado em 1998 pelo Ministério da Educação, referido anteriormente no ponto 4.2., sintetizou os aspectos a considerar na reorganização curricular do ensino básico de modo a garantir uma efectiva congruência na estrutura curricular da escolaridade básica e salientou que a escola precisa de se assumir como um espaço privilegiado de educação para a cidadania e de integrar e articular, na sua oferta curricular, experiências diversificadas, nomeadamente mais espaços de efectivo envolvimento dos alunos e actividades de apoio ao estudo.

De acordo com estas perspectivas e como resultado da reflexão, dos debates e da experiência adquirida, foi apresentada uma proposta estruturada em Março de 2000, a qual veio a dar origem ao Decreto- 
-Lei n. ${ }^{\circ}$ 6/2001, de 18 de Janeiro, consagrando uma nova organização curricular a partir do ano lectivo de 2001/2002.

A Reorganização Curricular orienta-se pelos objectivos que a Lei de Bases do Sistema Educativo estabelece para o ensino básico, nomeadamente o de assegurar uma formação comum a todos os alunos que thes garanta o desenvolvimento dos seus interesses e aptidões e que promova a realização individual em harmonia com valores de solidariedade social. Toma como ponto de partida os dispositivos legais que enquadram a organização curricular e a avaliação no ensino básico, nomeadamente o Decreto-Lei 286/89 de 29 de Agosto e o Despacho Normativo n. ${ }^{0} 98-A / 92$, de 20 de Junho, alterado pelo Despacho Normativo n. ${ }^{0}$ 644-A/94 de 13 de Setembro. Foi ainda publicado o Despacho Normativo n. ${ }^{\circ}$ 30/2001, de 19 de Julho que concretiza a determinação das orientações e disposições relativas à avaliação no ensino básico consagradas no Decreto-Lei n. ${ }^{\circ}$ 6/2001, de 18 de Janeiro e substitui o Despacho Normativo n. ${ }^{\circ}$ 98-A/92, de 20 de Junho, e demais legislação subsequente sobre a mesma matéria.

O propósito essencial da reorganização curricular do ensino básico é o de criar condições para se concretizar uma formação de base para todos com qualidade das aprendizagens. Deste modo, são tomadas medidas (a nível legislativo) para enfrentar problemas persistentes reconhecidos pelo Ministério da Educação, tais como, a dificuldade em lidar com a diversidade de situacões educativas, o insucesso e abandono escolares ainda elevados e a falta de articulação e consistência entre os vários ciclos de escolaridade.

Entende-se que o currículo deve ser concebido de acordo com o princípio de que a sua concretização é um processo flexível, que necessita, nos diversos níveis, interpretação de cada contexto de trabalho, consideração dos recursos disponíveis e tomadas de decisão apropriadas, ou seja, «a própria noção de currículo integra a procura de respostas adequadas às diversas necessidades e características de cada aluno, grupo de alunos, escola ou região» (Abrantes, 2001:42).

A noção de currículo adoptada nesta reorganização está relacionada com três preocupações relacionadas entre si: diferenciação, adequação e flexibilização. A concretização do currículo pressupõe que se estabeleçam diferentes caminhos para alcançar aprendizagens bem sucedidas (diferenciação), a gestão curricular está relacionada com a responsabilização na procura das formas mais adequadas a cada situação concreta (adequação) e por último, todo este processo requer uma grande flexibili- 
zação. Na prática, cabe à escola, no quadro da respectiva autonomia e respeitando as orientações do currículo nacional, a responsabilidade de organizar e conduzir o processo de ensino/aprendizagem de modo adequado aos seus alunos, gerindo os recursos humanos e materiais disponíveis.

Adopta-se uma noção ampla de competência, que integra conhecimentos e atitudes e que pode ser entendida como um saber em acção. No que diz respeito à avaliação, retoma-se a ênfase no seu carácter formativo, assim como a valorização de uma lógica de ciclo. Nesta perspectiva, entende-se que a avaliação tem como principal função ajudar a promover ou a melhorar a formação dos alunos, deve ter um carácter essencialmente formativo e deve assumir igualmente um carácter positivo. A avaliação deve ter em vista apreciar a evolução dos alunos recorrendo a diversos modos e instrumentos, ao longo de cada ano e ciclo. As actividades de enriquecimento curricular devem ser encorajadas lnos domínios da educação física e desporto, das artes, das tecnologias e da experimentação científical uma vez que o currículo não se esgota nas componentes obrigatórias.

Convém salientar que a reorganização curricular contempla vários aspectos inovadores, um dos quais é a educação para a cidadania que é considerada como «uma componente do currículo de natureza transversal, em todos os ciclos. O seu objectivo central é o de contribuir para a construção da identidade e o desenvolvimento da consciência cívica dos alunos. (...) Aspectos como a educação para a saúde, a educação sexual, a educação rodoviária ou a educação ambiental, entre outros, deverão ser considerados, quer no trabalho a realizar nas áreas curriculares não disciplinares quer no âmbito das diversas disciplinas» (Abrantes, 2001:54). Trata-se, portanto, de um espaço de reflexão e de diálogo sobre preocupações sentidas e experiências vividas pelos alunos e também sobre temas e problemas relevantes de comunidade e sociedade. A utilização das tecnologias da informação e da comunicação faz parte integrante do currículo em todos os ciclos, assumindo igualmente uma natureza transversal.

Outro aspecto inovador é a criação de três novas áreas curriculares não disciplinares: o estudo acompanhado, a área de projecto e a formação cívica. Deste modo, «nesta reorganização curricular assume particular relevo a consagração no currículo de três novas áreas curriculares não disciplinares, bem como a obrigatoriedade do ensino experimental das ciências, o aprofundamento da aprendizagem das línguas modernas, o desenvolvimento da educação artística e da educação para a cidadania 
e o reforço do núcleo central do currículo nos domínios da língua materna e da matemática» (Decreto-Lei n. ${ }^{\circ}$ 6/2001:258). As três novas áreas, para além do seu carácter não disciplinar, assumem uma natureza transversal e integradora, são transversais na medida em que atravessam todas as disciplinas e áreas do currículo e são integradoras porque se constituem como espaços de integração de diversos saberes.

Este documento consagra também a educação para a cidadania, o domínio da Língua Portuguesa, a valorização da dimensão humana do trabatho, a utilização das tecnologias de informação e comunicação como formações transdisciplinares que atravessam todas as disciplinas e áreas do currículo. Assim, podemos encontrar expressa nos seus princípios orientadores a indicação da integração da educação para a cidadania em todas as áreas curriculares com carácter transversal. É ainda referido no Decreto-Lei que «a educação para a cidadania bem como a valorização da língua portuguesa e da dimensão humana do trabalho constituem formação transdisciplinares, no ambiente do ensino básico» (art. ${ }^{0} 6 .^{\circ},{ }^{\circ} .{ }^{0} 1$ ).

De entre as três novas áreas curriculares não disciplinares - área de projecto, estudo acompanhado e formação cívica - salientamos esta última uma vez que a formação cívica é considerada como o «espaço privilegiado para o desenvolvimento da educação para a cidadania, visando o desenvolvimento da consciência cívica dos alunos como elemento fundamental no processo de formação de cidadãos responsáveis, críticos, activos, intervenientes, com recurso, nomeadamente, ao intercâmbio de experiências vividas pelos alunos e à sua participação, individual e colectiva, na vida da turma, da escola e da comunidade» (art. ${ }^{\circ}$ 5. $^{\circ}$, n. $^{\circ} 3$, alínea c).

A actividade a desenvolver neste domínio contará com o apoio de um tempo semanal para sessões de informação e de debate que, entre outros, pode assumir o formato de assembleia de turma. Uma assembleia de turma é um espaço de debate de problemas que envolve a tomada de decisões, resolução de situações difíceis e oportunidades de desenvolvimento do raciocínio moral. É ainda um espaço que pode proporcionar momentos de reflexão sobre a participação dos alunos na vida da turma e da escola e sobre os princípios democráticos que regem o seu funcionamento. Estas sessões envolvem uma nova organização da própria turma de modo a permitir a interacção e o conhecimento de dilemas morais para os quais os próprios alunos procuram soluções, justificando as suas opções e confrontando-as com as dos colegas, sendo assim promovido o desenvolvimento do raciocínio e da capacidade de argumentação. 
No $1 .{ }^{\circ}$ ciclo, o professor titular da turma será o responsável. No $2 .^{\circ}$ e no 3. ${ }^{\circ}$ ciclo, o tempo no horário dos alunos destinada a este fim será atribuído, em princípio, ao director de turma.

É possível encontrar neste Decreto-Lei (n. ${ }^{\circ}$ 6/2001) um princípio que reconhece o pluralismo cultural nas escolas portuguesas nas quais verificamos, cada vez mais, um maior número de crianças estrangeiras, filhas de imigrantes e revelador de uma preocupação com o sucesso educativo e o sucesso humano dessas crianças. Assim, afirma-se que «as escolas devem proporcionar actividades curriculares específicas para a aprendizagem da Língua Portuguesa como segunda língua aos alunos cuja língua materna não seja o português» (art. ${ }^{8} .^{\circ}$ ).

Em legislação posterior, que desenvolve e concretiza orientações e disposições relativas à avaliação consagradas no Decreto-Lei n. ${ }^{0}$ 6/2001, de 18 de Janeiro, verificamos que o reconhecimento do pluralismo cultural e a preocupação com o percurso escolar e com a promoção do sucesso educativo dos alunos imigrantes continuam a estar presentes nas directrizes expressas pelo Ministério da Educação. Assim, no Despacho Normativo n. ${ }^{0}$ 1/2005, de 5 de Janeiro, está igualmente patente o reconhecimento da diversidade cultural que caracteriza a escola portuguesa quando declara que «a grande diversidade de alunos do ponto de vista etário, cultural e social que frequenta actualmente a escola básica pode ser encarada como um contributo para a construção de uma sociedade plural e tolerante, na qual todos os intervenientes têm um papel muito importante a desempenhar». Este despacho anuncia ainda que as aprendizagens no âmbito da educação para a cidadania constituem objecto de avaliação em todas as disciplinas e áreas curriculares.

O Despacho Normativo n. ${ }^{\circ}$ 50/2005, de 20 de Outubro, expressa que a promoção de uma cultura de qualidade e de rigor deve assegurar a todos os alunos as condições adequadas à obtenção do sucesso educativo. O despacho define princípios de actuação e normas orientadoras com vista ao sucesso educativo dos alunos e menciona que o plano de recuperação (conjunto de actividades concebidas no âmbito curricular e de enriquecimento curricular que contribuam para que os alunos adquiram as aprendizagens e as competências consagradas nos currículos em vigor do ensino básicol pode integrar, entre outras, «actividades de ensino de língua portuguesa para alunos oriundos de países estrangeiros» (art. ${ }^{0} 2,{ }^{\circ}{ }^{0} 3$, alínea e). 


\subsection{O Currículo Nacional do Ensino Básico: Competências Essenciais}

Em Setembro de 2001, o Ministério da Educação/DEB publicou um documento que apresenta o conjunto de competências consideradas essenciais no âmbito do currículo nacional. Este documento inclui as competências de carácter geral, a desenvolver ao longo dos três ciclos do ensino básico, assim como as competências específicas relativas a cada uma das áreas disciplinares e disciplinas, no conjunto dos três ciclos e em cada um deles. Para além disso, explicita os tipos de experiências de aprendizagem que devem ser proporcionadas aos alunos.

É utilizada a noção de competência, entendida como saber em acção ou em uso. A competência «diz respeito ao processo de activar recursos (conhecimento, capacidades, estratégias) em diversos tipos de situações, nomeadamente situações problemáticas» (DEB, 2001:9). A cultura geral que todos os alunos devem desenvolver no ensino básico «pressupõe a aquisição de um certo número de conhecimentos e a apropriação de um conjunto de processos fundamentais mas não se identifica com o conhecimento memorizado de termos, factos e procedimentos básicos, desprovido de elementos, compreensão, interpretação e resolução de problemas» (ibidem).

O documento considera que faz parte integrante do currículo a abordagem de termos transversais às várias áreas disciplinares no âmbito da educação para os direitos humanos, da educação ambiental e da educação para a saúde e o bem-estar, em especial, a educação alimentar, a educação sexual e a educação para a prevenção de situações de risco pessoal. Estes temas devem ser trabalhados em duas perspectivas, por um lado na concepção e desenvolvimento de projectos interdisciplinares, por outro lado, através de aprendizagens específicas no âmbito das várias disciplinas.

As competências essenciais devem ser entendidas «à luz dos princípios de diferenciação pedagógica, adequação e flexibilização, que estão subjacentes ao processo de reorganização do ensino básico» (idem:11). Quer isto dizer que haverá diversos caminhos para desenvolver as competências, de acordo com a diversidade das situações concretas.

O documento «Currículo Nacional do Ensino Básico: competências essenciais» salienta também os problemas resultantes do «número crescente de crianças e jovens que frequentam as nossas escolas e cuja língua materna não é o português» (ibidem). Esses problemas justificam 
a realização de actividades curriculares específicas de português como segunda língua, de acordo com o Decreto-Lei 6/2001 (art. ${ }^{\circ}$ 8. $^{\circ}$ ). Nesta perspectiva, o documento indica que deverão ser elaboradas orientações concretas para o desenvolvimento de actividades em relação às diversas minorias linguísticas, no entanto as experiências educativas a proporcionar a estes alunos devem visar o desenvolvimento das competências expressas ao longo do documento em análise.

Adoptando como referentes os pressupostos da Lei de Bases do Sistema Educativo, enunciam-se no documento princípios e valores orientadores do currículo, entre os quais se destacam os seguintes, mais relevantes no âmbito da educação para a cidadania:

- a construção e a tomada de consciência da identidade pessoal e social;

- a participação na vida cívica de forma livre, responsável, solidária e crítica;

- o respeito e a valorização da diversidade dos indivíduos e dos grupos quanto às suas pertenças e opções;

- a construção de uma consciência ecológica conducente à valorização e preservação do património natural e cultural;

- a valorização das dimensões relacionais da aprendizagem e dos princípios éticos que regulam o relacionamento com o saber e com os outros.

Na continuidade destas ideias expressas no documento Currículo Nacional do Ensino Básico: competências essenciais, consideramos que o desenvolvimento de competências na educação para a cidadania em contexto escolar torna-se fundamental, pois a escola, entendida como um lugar de aprendizagem e de convivência social, deve oferecer não apenas um espaço físico e organizacional, mas também um espaço relacional, de convivência, de cooperação e de resolução de conflitos. Porém, estas competências «só têm sentido se forem ancoradas numa identidade e em convicções democráticas. Elas permitem pôr em marcha uma parte dos ideais relativos, por exemplo, à transparência das decisões, ao estrito respeito pelos procedimentos, à igualdade de oportunidades, à justiça» (Perrenoud, 2001:90). A construção de competências deverá iniciar-se desde o início da escolarização, mas esta escolarização não exclui, antes pelo contrário que se aposte também no seu desenvolvimento através da experiência de vida e de uma prática reflexiva, pois uma efectiva formação deveria articular essas dimensões. 
De acordo com Praia (1999:25), o principal objectivo da educação para a cidadania «é proporcionar a aquisição de competências que propiciem a inserção responsável, e com gosto, do jovem na comunidade». A concretização destas competências, que a autora designa de competências de vida, é avaliada, basicamente, através do comportamento e das atitudes demonstradas pelos alunos.

\section{ORIENTAC̣ÕES A NÍVEL INTERNACIONAL}

A nível internacional, na última década, a educação para a cidadania originou directrizes e orientações concretas, designadamente no âmbito da União Europeia e do Conselho da Europa, em sintonia com trabalhos desenvolvidos pela ONU e UNESCO. Os valores humanistas da pessoa, dos direitos humanos e da democracia norteiam estas directrizes e orientações. A nível conceptual, procura-se incrementar a complementaridade entre a cidadania nacional e a cidadania europeia para promover os valores políticos de proximidade ao cidadão, responsabilização dos governantes, legitimidade nacional e assegurar a segurança e defesa nacionais. Aliás, os tratados de Maastricht e de Amesterdão declaram a cidadania europeia complementar à cidadania nacional, que se expressa por um conjunto de medidas e de direitos, como a liberdade de circulação e de instalação. A nível metodológico, observa--se um consenso em integrar a cidadania nos currículos escolares, apesar de algumas discrepâncias em relação a conteúdos educativos, metas e objectivos, estratégias didácticas, modos de integração, formação de professores e produção de materiais de apoio.

Diversos documentos internacionais recentes (UNESCO, 1996; Comissão Europeia, 1995, 1997; OCDE, 1994, 1998) reflectem sobre a temática da cidadania e sobre o papel da escola na sua promoção, tendo vindo a ganhar influência e visibilidade dimensões como a promoção da formação ao longo da vida, das competências de pensar, do respeito pela diversidade e da promoção da qualidade para todos. Estas preocupações sugerem algumas novas valências associadas à noção de cidadania, que se reportam a valores com relevância nas sociedades actuais (caracterizadas pela sua complexidade e pela heterogeneidade crescente das populações), tais como, a formação para a tolerância, respeito pela diferença e a formação para uma cidadania aberta, europeia e universal. Actualmente, a questão da educação para a cidadania encontra-se ainda marcada pelo imperativo de resolução e pacificação de conflitos, do alargamento dos espaços económicos e físicos e da necessidade de novas formas de convivência de culturas, de valores e de identidades bastante distintas. 
Numa sociedade caracterizada por uma maior complexidade, maior diversidade e desigualdade, com um ritmo de mudanças muito rápido constatamos a exigência de respostas mais flexíveis e de procedimentos e sistemas participativos que envolvam todos os membros da sociedade, no entanto, reconhecemos que a sua concretização não é fácil. É nesse sentido que se enuncia, no Relatório para a UNESCO sobre a educação para o século XXI, que «escolher um determinado tipo de educação equivale a optar por um determinado tipo de sociedade», completando que «as opções educativas devem fazer-se no sentido duma maior responsabilização de cada cidadão, preservando o princípio fundamental da igualdade de oportunidades» (Delors et al, 1996: 166).

Este relatório salienta ainda que «à educação cabe fornecer, de algum modo, a cartografia do mundo complexo e constantemente agitado, e, ao mesmo tempo, a bússola que permita navegar através dele» (idem:77). Para isso, determina quatro pilares para a educação, já referidos anteriormente no ponto 5 do capítulo II, que agora explicitamos:

- Aprender a conhecer lentendido como aquisição de instrumentos de compreensão de um mundo em mudançal.

Esta forma de aprender deve ser entendida como um processo que permite ao indivíduo adquirir instrumentos de compreensão no mundo que o rodeia, de forma a se realizar dignamente como pessoa e membro da sociedade. Trata-se de «aprender a aprender», exercitando a atenção, a memória e o pensamento, estimulando o espírito crítico face à multiplicidade de informações com as quais a pessoa se confronta no seu dia-a-dia. Ao ensino formal compete fornecer a todos os alunos uma cultura geral que thes possibilite descodificar a realidade, num vaivém permanente entre o pensamento concreto e o pensamento abstracto, através da combinação dos métodos indutivo e dedutivo.

- Aprender a fazer (para poder agir sobre o meio envolvente).

Esta forma de aprender está relacionada com o «aprender a conhecer» e entende-se como a forma de levar à prática o conhecimento, ou seja, a preparação para o desempenho de tarefas. No entanto, a visão funcionalista do saber, concretizada em tarefas da rotina, é superada por novas competências que englobam, não só as qualificações profissionais, mas também tarefas de concepção, estudo e organização, assumidas individualmente e em equipa.

Deste modo, a escola não pode limitar-se apenas à mera transmissão de práticas instrumentais e de conhecimentos, mas deve proporcionar 
aos alunos a vivência de experiências que lhes possibilitem exercitar a inovação, a criatividade e o risco para enfrentar e resolver problemas do dia-a-dia. Assim, a educação deve ir mais além do aprender a conhecer e a fazer, promovendo uma visão mais humanista e humanizadora, favorecendo a descoberta do outro através de aprendizagens significativas de carácter relacional e ético.

- Aprender a viver juntos, aprender a viver com os outros lpara cooperativamente participar com os outros, descobrindo-os e descobrindo-se a si próprio).

A educação para a alteridade passa pela descoberta de nós próprios e pela relação de semelhanças e interdependências entre todos os seres humanos, começando pelos mais próximos. Não é suficiente ensinar conhecimentos sobre a diversidade humana, é necessário aprender no quotidiano, a descobrir e reconhecer o outro, não como uma ameaça mas como alguém com quem podemos desenvolver objectivos e projectos comuns. Trata-se de valorizar o que é comum e não apenas as diferenças (pluralismo), lutando contra todas as formas de discriminação, indiferença e rivalidade que têm impedido os mais desfavorecidos de participar na vida comunitária. O diálogo, a resolução não violenta de conflitos, a cooperação e a solidariedade são alguns dos instrumentos que as pessoas ou organizações devem aspirar, questionando simultaneamente os valores e as práticas da nossa sociedade actual.

- Aprender a ser (concretização/integração das aprendizagens anteriores).

É imprescindível que o «aprender a ser» seja o pilar fundamental da educação do ser humano, pois com a excessiva racionalidade instrumental corre-se o risco de desumanizar o homem.

Este ditame, de natureza individual e social, permite à pessoa o seu desenvolvimento total permitindo comportar-se como ser consciente, autónomo, responsável e justo. Assim, o aprender a ser integra o «aprender a conhecer», o «aprender a fazer» e o «aprender a viver em comum», constituindo o todo educativo. Deste modo, a educação, mais do que preparar crianças para uma determinada sociedade, deve proporcionar-lhes referências e meios que potenciem a descoberta e o desenvolvimento das suas capacidades intelectuais, físicas, relacionais, comunicativas, .... de forma a serem actores críticos na construção de uma nova sociedade. 
Na sequência do relatório dos anos setenta que, tentando contrariar a tendência tecnicista que se começava a impor, reclamou a importância do «aprender a ser», o relatório da UNESCO dos anos noventa continua a valorizar esta dimensão mas evidenciando a necessidade de se aprender a viver numa sociedade multicultural, de a conviver com a diferença e a preparação do futuro cidadão para a participação activa num projecto de sociedade, «mostrando-lhe os seus direitos e deveres, mas também desenvolvendo as suas competências sociais e estimulando o trabalho em equipa na escola» (Delors et al, 1996:53). O relatório salienta ainda que a maior ambição da educação será «dar a todos os meios necessários a uma cidadania consciente e activa, que só pode realizar-se, plenamente, num contexto de sociedades democráticas» (Delors et al, 1996:45). Para o aluno a educação cívica implica a «adesão a valores, a aquisição de conhecimentos e a aprendizagem de práticas de participação na vida pública» (idem: 54). Esta educação não pode ser considerada neutra do ponto de vista ideológico, pois questiona a consciência do aluno. Para que esta consciência permaneça independente é necessário que a educação desenvolva no aluno a capacidade crítica que the possibilite ter um pensamento livre e uma acção autónoma. A educação será o seu guia, quando se tornar cidadão e tiver que «conciliar o exercício dos direitos individuais, fundados nas liberdades públicas, com a prática dos deveres e da responsabilidade em relação aos outros e às suas comunidades de pertença» (idem: 55). É igualmente realçado que a educação para a cidadania não se limita apenas ao espaço e ao tempo da educação formal, sendo indispensável nela envolver directamente as famílias e os outros membros da comunidade. 



\section{PARTE II - CONTEXTO DA INVESTIGAC̣ÃO EMPÍRICA}

\section{CAPÍTULO IV - OPC̣ÕES METODOLÓGICAS DA INVESTIGAC̣ÃO}

\section{NOTAS INTRODUTÓRIAS}

Neste ponto do trabalho, expomos o nosso problema em estudo e as nossas questões de investigação, as quais iremos, no desenvolvimento do nosso trabalho, tentar aprofundar e esclarecer. Apresentamos a metodologia do trabalho empírico utilizada, definindo e caracterizando a amostra que inclui três grupos distintos, professores, alunos e encarregados de educação, referindo a relação entre eles.

A nossa preferência pela investigação qualitativa prende-se com a compreensão dos fenómenos educativos a partir da indução dos significados particulares e complexos de cada contexto, que no nosso caso é o da escola do $1 .{ }^{\circ}$ Ciclo do Ensino Básico. Mostramos a nossa opção pela entrevista como instrumento de recolha de dados já que a nossa preocupação é aprofundar vivências pessoais, acontecimentos e factos. Deste modo, define-se o tipo de entrevista utilizada, salientando alguns cuidados na sua construção e aplicação. Por último, apresentamos os procedimentos para a análise da informação por nós adoptados.

Referimos ainda que este trabalho possui um carácter exploratório, cujos resultados não poderão ser generalizados, procurando abrir campo para a reflexão. A reduzida dimensão da amostra não permite, portanto, cobrir a diversidade de percursos e de realidades que afectam os três grupos em análise, mas dela se podem obter importantes e preciosas informações, utilizando-as com as devidas cautelas e reservas. Desta forma, a preocupação que assistiu à recolha da informação foi a de apreender o modo como as realidades são vividas, interpretadas e explicadas.

\section{A ENUNCIAC̣ÃO DO PROBLEMA}

Na nossa investigação, o que nos propomos fazer é procurar entender qual o papel do professor do $1 .{ }^{\circ}$ Ciclo do Ensino Básico (1. $\left.{ }^{\circ} \mathrm{CEB}\right)$ na construção da cidadania em contexto intercultural.

Este estudo está limitado a professores do $1 .{ }^{\circ}$ CEB pois é o nível de ensino onde leccionamos e sobre o qual existem poucos estudos realizados. Por outro lado, sabemos que os professores do $1 .{ }^{\circ}$ CEB têm um papel muito importante no desenvolvimento e na formação integral dos seus alunos 
e também na promoção de igualdades educativas assegurando a todas as crianças as aprendizagens de que depende largamente o sucesso nos percursos escolares ulteriores. Este estudo engloba ainda mais dois grupos de sujeitos, alunos vindos de outros países, com culturas diferentes (de origem brasileira e de países do Leste da Europa) e os seus encarregados de educação, pois o nosso estudo insere-se em contexto intercultural.

Consoante com o objectivo de obter informações que permitissem estudar, compreender e explicar qual o papel do professor do $1 .{ }^{\circ}$ Ciclo do Ensino Básico (1. ${ }^{\circ}$ CEB) na construção da cidadania em contexto intercultural, definiram-se algumas questões de investigação que iremos, no desenvolvimento do nosso trabalho de investigação, tentar observar, esclarecer e aprofundar:

- Como é que as políticas educativas têm valorizado a educação para a cidadania, tendo em conta a realidade multicultural e as mudanças ocorridas no nosso país?

- De que forma o currículo nacional para o $1 .{ }^{\circ}$ CEB pode ser percepcionado e gerido numa perspectiva de educação para a cidadania global e independente com particular incidência para a vertente intercultural?

- De que modo os professores aplicam na sua prática pedagógica as orientações do Ministério da Educação para a educação intercultural e para a educação para a cidadania?

- De que forma é que as práticas pedagógicas no âmbito da educação para a cidadania, num contexto intercultural e pluralista, contribuem para aprendizagens mais significativas e para o desenvolvimento integral dos alunos?

- De que modo a educação para a cidadania pode contribuir para o desenvolvimento da consciência cívica dos alunos como elemento fundamental no processo de formação de cidadãos responsáveis, críticos, activos e intervenientes?

- Qual a relação entre o sucesso escolar dos alunos brasileiros e de países de leste da Europa, com diferentes culturas da cultura maioritária, e a educação intercultural?

- Como sentem ou vêem a escola e a sua integração no meio escolar estes alunos (brasileiros e originários do leste da Europal com culturas diferentes da maioria dos alunos presentes na instituição escolar? 
- Como sentem ou vêem a escola e a integração dos filhos no meio escolar os pais destes alunos (imigrantes brasileiros e de países de leste da Europal com culturas minoritárias?

Consideramos, face a estas questões, que o presente estudo se enquadra no âmbito de uma investigação caracterizada por um levantamento de informação relativa atitudes, opiniões, condições e procedimentos, e ainda devido à opção metodológica de utilizar, no trabalho empírico, uma abordagem qualitativa. Os métodos qualitativos têm vindo a ganhar relevo, como estratégia de investigação, no estudo das questões educacionais, e para isso tem contribuído o enfraquecimento do positivismo. A investigação qualitativa tem por base uma perspectiva hermenêutica e interpretativa, ou seja, pretende a compreensão dos fenómenos, nomeadamente dos fenómenos educativos, a partir da indução.

Recorremos a instrumentos e a procedimentos que possibilitaram ir para além da realidade dos números e das análises de superfície, aprofundando acontecimentos, pessoas e factos. Assim, optámos por uma metodologia de análise centrada na realização de entrevistas semi-directivas individuais para alcançar a compreensão da realidade a partir de padrões provenientes da recolha de dados. Este tipo de entrevista parte de um quadro temático de referência (ou grelha de temas). 0 entrevistador elabora um guião, com temas e tópicos a tratar durante a entrevista, no entanto, a ordem pela qual os temas são abordados é livre mas, se o entrevistado não abordar espontaneamente determinado tema o entrevistador deve propor-lhe esse tema.

\section{A AMOSTRA}

A incidência deste estudo, no que diz respeito às escolas, professores e alunos escolhidos, centrou-se nos concelhos da Póvoa de Varzim e de Vila do Conde.

Optou-se por contactar pessoalmente as escolas mais centrais lescolas sedes) e telefonicamente as escolas mais afastadas (escolas das freguesias), no sentido de apurar a existência de alunos provenientes de outros países a frequentar o 1. ${ }^{\circ}$ Ciclo do Ensino Básico, uma vez que a nossa investigação pretendia decorrer em contexto escolar intercultural.

Após esta auscultação verificámos que algumas escolas apresentavam um número considerável de crianças estrangeiras, filhas de imigrantes que se encontram a trabalhar em Portugal. As crianças encontradas em 
maior número foram, em primeiro lugar as brasileiras, em segundo, crianças oriundas se países do leste europeu e também crianças chinesas, embora em menor número. Também se encontrou um número significativo de crianças filhas de ex-emigrantes portugueses.

Para obter as respostas às nossas questões, a nossa escolha recaiu no grupo de alunos brasileiros e de países de leste, nos seus professores e ainda nas suas encarregadas de educação, pois consideramos que as suas opiniões poderiam ser uma mais-valia para este trabalho. No entanto, devido a incompatibilidade de horários o contacto com as encarregadas de educação revelou-se um pouco difícil e não foi possível entrevistar todas (as dez encarregadas de educação) que pretendíamos.

Assim, temos uma «amostra de conveniência» (Carmo e Ferreira, 1998:197) que engloba:

- Dez alunos do 1.० CEB:

Cinco de origem brasileira e cinco de origem de países do leste europeu (Ucrânia, Rússia, Moldávia e Bulgária).

- Dez professores do 1. CEB lprofessores dos alunos acima referidos).

- Sete encarregadas de educação?.

Estes alunos e seus respectivos professores pertencem a quatro escolas do 1. ${ }^{\circ}$ CEB do concelho da Póvoa de Varzim e a duas escolas do 1. ${ }^{\circ}$ CEB do concelho de Vila do Conde.

Após a selecção das escolas foi estabelecido o contacto pessoal com os presidentes e/ou vice-presidentes dos Conselhos Executivos dos Agrupamentos aos quais pertencem as escolas envolvidas, no sentido de obter autorização para realizar as entrevistas (pedido esse que foi formalizado através de uma carta).

Enquanto se aguardavam as autorizações para realizar as entrevistas, estabeleceu-se o primeiro contacto com os professores no sentido de os informar da natureza e objectivo do estudo e ainda solicitar a sua colaboração. Todos eles se mostraram receptivos e disponíveis para colaborar.

A participação dos sujeitos da nossa amostra foi voluntária em todos os grupos em estudo. 0 consentimento dos alunos foi reforçado pelo con-

9. As encarregadas de educação são mães de oito dos alunos acima referidos. 
tacto prévio com os professores e, por intermédio destes, com as suas encarregadas de educação.

Nos seguintes quadros, apresentamos o conjunto dos sujeitos entrevistados e especificamos algumas das suas características, recolhidas através de fichas de identificação preenchidas após a realização da entrevista:

- o quadro IX refere-se às características actuais a nível profissional dos professores entrevistados e indica ainda o código dos seus alunos que foram entrevistados;

- o quadro X apresenta elementos pessoais e do percurso académico dos professores entrevistados;

- o quadro XI mostra a caracterização dos alunos entrevistados;

- no quadro XII caracterizam-se as encarregadas de educação entrevistados;

- o quadro XIII expõe as relações entre os entrevistados dos três grupos em estudo para uma melhor compreensão da dinâmica das entrevistas.

\section{Quadro IX - Caracterização dos professores entrevistados. Dados relativos à docência}

\begin{tabular}{|c|c|c|c|c|c|}
\hline Professor & $\begin{array}{c}\text { Anos de serviço } \\
\text { na docência (a) }\end{array}$ & $\begin{array}{c}\text { Situação } \\
\text { profissional }\end{array}$ & $\begin{array}{l}\text { Função na escola } \\
\text { (b) }\end{array}$ & $\begin{array}{l}\text { Agrupamento } \\
\text { (c) }\end{array}$ & $\begin{array}{c}\text { Aluno da turma } \\
\text { entrevistado }\end{array}$ \\
\hline P 1 B & 3 & $\begin{array}{l}\text { Professora } \\
\text { Contratada }\end{array}$ & $\begin{array}{c}\text { Titular de Turma } \\
4 .^{\circ} \text { ano } \\
\end{array}$ & $\begin{array}{l}\text { Agrupamento } \\
\text { Vertical Azul }\end{array}$ & A $3 B$ \\
\hline P $2 L$ & 26 & $\begin{array}{c}\text { Professora do } \\
\text { Quadro de Escola }\end{array}$ & $\begin{array}{c}\text { Titular de Turma } \\
1 .^{\circ} \text { ano } \\
\end{array}$ & \begin{tabular}{|c|} 
Agrupamento \\
Vertical Vermelho
\end{tabular} & A $3 L$ \\
\hline P $3 L$ & 2 & $\begin{array}{l}\text { Professora } \\
\text { Contratada }\end{array}$ & $\begin{array}{c}\text { Titular de Turma } \\
2 .^{\circ} \text { ano }\end{array}$ & \begin{tabular}{|c|} 
Agrupamento \\
Vertical Vermelho
\end{tabular} & A $2 L$ \\
\hline$P 4 B$ & 27 & $\begin{array}{c}\text { Professora do } \\
\text { Quadro de Escola }\end{array}$ & $\begin{array}{c}\text { Titular de Turma } \\
\text { 3. }{ }^{\circ} \text { Ano/ } \\
\text { /Coordenadora } \\
\text { do Eco-Escolas }\end{array}$ & $\begin{array}{l}\text { Agrupamento } \\
\text { Vertical Azul }\end{array}$ & A 2 B \\
\hline P 5 B & 3 & $\begin{array}{c}\text { Professora do } \\
\text { Quadro de Zona } \\
\text { Pedagógica }\end{array}$ & $\begin{array}{c}\text { Titular de Turma } \\
2 .^{\circ} \text { Ano }\end{array}$ & $\begin{array}{c}\text { Agrupamento } \\
\text { Vertical Vermelho }\end{array}$ & A 5 B \\
\hline$P 6 L$ & 2 & $\begin{array}{l}\text { Professor } \\
\text { Contratado }\end{array}$ & $\begin{array}{c}\text { Titular de Turma } \\
\text { 3. }{ }^{\circ} \text { Ano }\end{array}$ & $\begin{array}{l}\text { Agrupamento } \\
\text { Vertical Verde }\end{array}$ & A $5 \mathrm{~L}$ \\
\hline P 7 B & 9 & $\begin{array}{c}\text { Professora do } \\
\text { Quadro de Zona } \\
\text { Pedagógica }\end{array}$ & $\begin{array}{c}\text { Titular de Turma } \\
\text { 1. }{ }^{\circ} \text { Ano }\end{array}$ & $\begin{array}{l}\text { Agrupamento } \\
\text { Vertical Azul }\end{array}$ & A 4 B \\
\hline
\end{tabular}


(continuação)

\begin{tabular}{|c|c|c|c|c|c|}
\hline Professor & $\begin{array}{c}\text { Anos de serviço } \\
\text { na docência (a) }\end{array}$ & $\begin{array}{c}\text { Situação } \\
\text { profissional }\end{array}$ & $\begin{array}{c}\text { Função na escola } \\
\text { (b) }\end{array}$ & $\begin{array}{c}\text { Agrupamento } \\
\text { (c) }\end{array}$ & $\begin{array}{c}\text { Aluno da turma } \\
\text { entrevistado }\end{array}$ \\
\hline P 8 L & 24 & $\begin{array}{c}\text { Professora do } \\
\text { Quadro de Escola }\end{array}$ & $\begin{array}{c}\text { Titular de Turma } \\
1 .{ }^{\circ} \text { Ano }\end{array}$ & $\begin{array}{c}\text { Agrupamento } \\
\text { Vertical Vermelho }\end{array}$ & A $4 \mathrm{~L}$ \\
\hline P 9 B & 15 & $\begin{array}{c}\text { Professora do } \\
\text { Quadro de Zona } \\
\text { Pedagógica }\end{array}$ & $\begin{array}{c}\text { Titular de Turma } \\
2 .^{\circ} \text { Ano }\end{array}$ & $\begin{array}{c}\text { Agrupamento } \\
\text { Vertical Amarelo }\end{array}$ & A 1 B \\
\hline P 10 L & 23 & $\begin{array}{c}\text { Professora do } \\
\text { Quadro de Escola }\end{array}$ & $\begin{array}{c}\text { Titular de Turma } \\
2 .{ }^{\circ} \text { Ano }\end{array}$ & $\begin{array}{c}\text { Agrupamento } \\
\text { Vertical Amarelo }\end{array}$ & A 1 L \\
\hline
\end{tabular}

(a) 0 tempo de serviço refere-se a Agosto de 2003.

(b) Para além da actividade docente, os professores não desempenham qualquer outro cargo na escola, com excepção da entrevistada P4B.

(c) Os nomes dos agrupamentos são fictícios.

\section{Quadro X - Caracterização dos professores entrevistados. Dados pessoais e académicos}

\begin{tabular}{|c|c|c|c|c|c|c|}
\hline \multirow{3}{*}{ Professor } & \multirow{3}{*}{ Sexo } & \multirow{3}{*}{ Idade } & \multicolumn{4}{|c|}{ Habilitações Académicas } \\
\hline & & & \multicolumn{2}{|c|}{ Formação Inicial } & \multicolumn{2}{|c|}{ Formação Complementar } \\
\hline & & & Instituição Formadora & \begin{tabular}{|c|} 
Ano \\
de obtenção \\
de diploma
\end{tabular} & Instituição Formadora & \begin{tabular}{|c|} 
Ano \\
de obtenção \\
de diploma
\end{tabular} \\
\hline P $1 \mathrm{~B}$ & F & 26 & $\begin{array}{c}\text { Instituto Superior } \\
\text { de Ciências Educativas } \\
\text { de Felgueiras }\end{array}$ & 1999 & & \\
\hline P $2 L$ & F & 49 & $\begin{array}{l}\text { Escola do Magistério } \\
\text { Primário de Guimarães }\end{array}$ & 1976 & $\begin{array}{c}\text { Escola Superior } \\
\text { de Educação de Fafe }\end{array}$ & 2003 \\
\hline P $3 L$ & $\mathrm{~F}$ & 25 & $\begin{array}{c}\text { Escola Superior } \\
\text { de Educação do Porto }\end{array}$ & 2000 & & \\
\hline P 4 B & $\mathrm{F}$ & 45 & $\begin{array}{l}\text { Escola do Magistério } \\
\text { Primário de Chaves }\end{array}$ & 1976 & $\begin{array}{c}\text { Escola Superior } \\
\text { de Educação do Porto }\end{array}$ & 2000 \\
\hline P 5 B & $\mathrm{F}$ & 25 & $\begin{array}{c}\text { Escola Superior } \\
\text { de Educação } \\
\text { de Viana do Castelo }\end{array}$ & 2001 & & \\
\hline P $6 L$ & M & 27 & $\begin{array}{l}\text { Instituto Superior } \\
\text { de Educação } \\
\text { de Felgueiras }\end{array}$ & 2002 & & \\
\hline P 7 B & $\mathrm{F}$ & 32 & $\begin{array}{c}\text { Escola Superior } \\
\text { de Educação da Guarda }\end{array}$ & 1994 & & \\
\hline P $8 \mathrm{~L}$ & $\mathrm{~F}$ & 48 & $\begin{array}{l}\text { Escola do Magistério } \\
\text { Primário de Guimarães }\end{array}$ & 1980 & $\begin{array}{c}\text { Escola Superior } \\
\text { de Educação de Fafe }\end{array}$ & 2001 \\
\hline P 9 B & $\mathrm{F}$ & 35 & $\begin{array}{l}\text { Escola do Magistério } \\
\text { Primário de Braga }\end{array}$ & 1988 & Universidade Aberta & 2001 \\
\hline P $10 \mathrm{~L}$ & $\mathrm{~F}$ & 46 & $\begin{array}{c}\text { Escola do Magistério } \\
\text { Primário } \\
\text { de Viana do Castelo }\end{array}$ & 1979 & $\begin{array}{c}\text { Escola Superior } \\
\text { de Educação } \\
\text { de Viana do Castelo }\end{array}$ & 2001 \\
\hline
\end{tabular}




\section{Quadro XI - Caracterização dos alunos entrevistados}

\begin{tabular}{|c|c|c|c|c|c|c|c|}
\hline Alunos & Nacionalidade & Sexo & Idade & $\begin{array}{c}\text { Tempo } \\
\text { de permanência } \\
\text { em Portugal (a) }\end{array}$ & $\begin{array}{c}\text { Ano } \\
\text { de escolaridade }\end{array}$ & $\begin{array}{l}\text { Agrupamento } \\
\text { (b) }\end{array}$ & $\begin{array}{l}\text { Professor } \\
\text { da turma } \\
\text { do aluno }\end{array}$ \\
\hline A $1 \mathrm{~L}$ & Russa & $\mathrm{F}$ & 9 & 2 Anos & $2 .^{\circ}$ & $\begin{array}{c}\text { Agrupamento } \\
\text { Vertical Amarelo }\end{array}$ & P $10 L$ \\
\hline A $2 \mathrm{~L}$ & Búlgara & $F$ & 9 & 2 Anos & $2 .^{\circ}$ & $\begin{array}{c}\text { Agrupamento } \\
\text { Vertical Vermelho }\end{array}$ & P $3 L$ \\
\hline A $3 L$ & Ucraniana & M & 6 & 1 Ano e 4 Meses & $1 .{ }^{\circ}$ & $\begin{array}{c}\text { Agrupamento } \\
\text { Vertical Vermelho }\end{array}$ & P $2 L$ \\
\hline A $4 \mathrm{~L}$ & Moldava & M & 6 & 2 Anos & $1 .{ }^{\circ}$ & $\begin{array}{c}\text { Agrupamento } \\
\text { Vertical Vermelho }\end{array}$ & P $8 \mathrm{~L}$ \\
\hline A $5 \mathrm{~L}$ & Ucraniana & $\mathrm{F}$ & 9 & 1 Ano e 5 Meses & $3 .^{\circ}$ & $\begin{array}{l}\text { Agrupamento } \\
\text { Vertical Verde }\end{array}$ & $P 6 L$ \\
\hline A $1 \mathrm{~B}$ & Brasileira & $\mathrm{F}$ & 7 & 1 Ano e 6 Meses & $2 .^{\circ}$ & $\begin{array}{c}\text { Agrupamento } \\
\text { Vertical Amarelo }\end{array}$ & P 9 B \\
\hline A 2 B & Brasileira & M & 9 & 1 Ano e 6 Meses & $3 .^{\circ}$ & $\begin{array}{l}\text { Agrupamento } \\
\text { Vertical Azul }\end{array}$ & $P 4 B$ \\
\hline A 3 B & Brasileira & $\mathrm{F}$ & 9 & 4 Meses & $4 .^{\circ}$ & $\begin{array}{l}\text { Agrupamento } \\
\text { Vertical Azul }\end{array}$ & $P 1 B$ \\
\hline A 4 B & Brasileira & M & 7 & 4 Meses & 1.0 & $\begin{array}{l}\text { Agrupamento } \\
\text { Vertical Azul }\end{array}$ & P 7 B \\
\hline A 5 B & Brasileira & M & 7 & 3 Anos & $2 .^{\circ}$ & $\begin{array}{c}\text { Agrupamento } \\
\text { Vertical Vermelho }\end{array}$ & P $5 \mathrm{~B}$ \\
\hline
\end{tabular}

(a) Tempo de permanência em Portugal até à data da entrevista.

(b) Os nomes dos agrupamentos são fictícios.

\section{Quadro XII - Caracterização das encarregadas de educação entrevistadas}

\begin{tabular}{|c|c|c|c|c|c|c|c|c|}
\hline $\begin{array}{c}\text { Encarregadas } \\
\text { de Educação }\end{array}$ & Idade & $\begin{array}{c}\text { Sexo } \\
\text { (a) }\end{array}$ & Nacionalidade & $\begin{array}{c}\text { Tempo de } \\
\text { Permanência } \\
\text { em Portugal } \\
\text { (b) }\end{array}$ & $\begin{array}{l}\text { Habilitações } \\
\text { Académicas }\end{array}$ & Profissão & $\begin{array}{c}\text { Dupla } \\
\text { Nacionalidade/ } \\
\text { /Motivo }\end{array}$ & $\begin{array}{c}\text { Encarregada } \\
\text { de Educação } \\
\text { do Aluno }\end{array}$ \\
\hline E $1 \mathrm{~L}$ & 32 & F & Búlgara & 2 Anos & $\begin{array}{l}\text { Frequência } \\
\text { da Faculdade } \\
\text { de Ed. Física }\end{array}$ & $\begin{array}{c}\text { Professora } \\
\text { de Ténis }\end{array}$ & Não & $\mathrm{A} 2 \mathrm{~L}$ \\
\hline E $2 \mathrm{~L}$ & 25 & $\mathrm{~F}$ & Ucraniana & $\begin{array}{l}2 \text { Anos } \\
\text { e } 6 \text { Meses }\end{array}$ & $10 .^{\circ}$ Ano & Desempregada & Não & A $3 \mathrm{~L}$ \\
\hline E $3 \mathrm{~L}$ & 30 & $\mathrm{~F}$ & Russa & 3 Anos & $11 .{ }^{\circ} \mathrm{Ano}$ & Costureira & Não & $A 1 L$ \\
\hline E $4 \mathrm{~L}$ & 27 & $\mathrm{~F}$ & Moldava & $\begin{array}{l}2 \text { Anos } \\
\text { e } 6 \text { Meses }\end{array}$ & $\begin{array}{l}\text { Licenciatura } \\
\quad \mathrm{em} \\
\text { Enfermagem }\end{array}$ & $\begin{array}{l}\text { Empregada } \\
\text { de Limpeza }\end{array}$ & Não & A $4 \mathrm{~L}$ \\
\hline$E 1 B$ & 33 & $\mathrm{~F}$ & Brasileira & $\begin{array}{l}1 \text { Ano } \\
\text { e } 6 \text { Meses }\end{array}$ & $12 .^{\circ} \mathrm{Ano}$ & Doméstica & Não & $A 1 B$ \\
\hline
\end{tabular}


(continuação)

\begin{tabular}{|c|c|c|c|c|c|c|c|c|}
\hline $\begin{array}{c}\text { Encarregadas } \\
\text { de Educação }\end{array}$ & Idade & $\begin{array}{c}\text { Sexo } \\
\text { (a) }\end{array}$ & Nacionalidade & $\begin{array}{c}\text { Tempo de } \\
\text { Permanência } \\
\text { em Portugal } \\
\text { (b) }\end{array}$ & $\begin{array}{c}\text { Habilitações } \\
\text { Académicas }\end{array}$ & Profissão & $\begin{array}{c}\text { Dupla } \\
\text { Nacionalidade/ } \\
\text { /Motivo }\end{array}$ & $\begin{array}{c}\text { Encarregada } \\
\text { de Educação } \\
\text { do Aluno }\end{array}$ \\
\hline E 2 B & 32 & $\mathrm{~F}$ & Brasileira & $\begin{array}{c}1 \text { Ano } \\
\text { e 6 Meses }\end{array}$ & $12 .{ }^{\circ}$ Ano & Doméstica & $\begin{array}{c}\text { Sim /filha de } \\
\text { pai português }\end{array}$ & A 2 B \\
\hline E 3 B & 28 & $F$ & Brasileira & $\begin{array}{c}2 \text { Anos } \\
\text { e 8 Meses }\end{array}$ & $11 .{ }^{\circ}$ Ano & $\begin{array}{c}\text { Empregada } \\
\text { Doméstica }\end{array}$ & $\begin{array}{c}\text { Sim/casada } \\
\text { com cidadão } \\
\text { português }\end{array}$ & $\begin{array}{c}\text { A 3 B } \\
\text { A 4 B }\end{array}$ \\
\hline
\end{tabular}

(a) As encarregadas de educação são todas do sexo feminino, mães dos alunos entrevistados. São as mães que mantêm o contacto com a escola e com a professora.

(b) Tempo de permanência em Portugal até à data da entrevista.

\section{Quadro XIII - Relações entre os entrevistados dos três grupos em estudo}

\begin{tabular}{|c|c|c|}
\hline Professores entrevistados & Alunos entrevistados & $\begin{array}{c}\text { Encarregadas de Educação } \\
\text { entrevistadas }\end{array}$ \\
\hline P $1 \mathrm{~B}$ & A 3 B & E 3 B \\
\hline P $2 L$ & A $3 L$ & E $2 \mathrm{~L}$ \\
\hline P $3 L$ & A $2 L$ & E $1 \mathrm{~L}$ \\
\hline P 4 B & A 2 B & E 2 B \\
\hline P 5 B & A 5 B & - \\
\hline$P 6 L$ & A $5 \mathrm{~L}$ & - \\
\hline P 7 B & A 4 B & E 3 B \\
\hline P 8 L & A $4 \mathrm{~L}$ & E $4 \mathrm{~L}$ \\
\hline P 9 B & A 1 B & E $1 \mathrm{~B}$ \\
\hline P $10 L$ & A $1 \mathrm{~L}$ & E $3 \mathrm{~L}$ \\
\hline
\end{tabular}

Nota: Em cada linha encontra-se o código do professor entrevistado, o aluno da sua turma entrevistado e o encarregado de educação entrevistado desse mesmo aluno.

\section{A ELABORAC̣ÃO DOS GUIÕES DAS ENTREVISTAS}

A entrevista é uma das «ferramentas» mais utilizadas na investigação social e educativa, sobretudo pela metodologia qualitativa. Com a utilização desta técnica de recolha de dados pretendíamos obter informações relevantes para a nossa investigação, através de um diálogo de carácter interactivo, e contribuir para uma análise mais profunda da realidade educativa, respeitando os quadros de referência e os discursos interpre- 
tativos dos entrevistados. Assim, era nossa intenção proceder à recolha de dados de opinião que permitissem «não só fornecer pistas para a caracterização do processo em estudo, como também conhecer, sob alguns aspectos os intervenientes do processo» (Estrela, 1986:354). «lsto é, se, por um lado, se procura uma informação sobre o real, por outro, pretende-se conhecer algo dos quadros conceptuais dos dadores dessa informação, enquanto elementos constituintes desse processo» (ibidem).

Consideramos que dos diferentes tipos de entrevista apresentados anteriormente, o que melhor se adapta a este estudo, é a entrevista semi- directiva, na medida em que após um guião inicial elaborado pelo entrevistador, o entrevistado, como referem Marconi e Lakatos (1990), tem a liberdade para desenvolver cada situação em qual-quer direcção que considere adequada. Deste modo, tentámos permitir que os entrevistados explorassem de forma flexível e aprofundada os seus relatos, e dar-lhes, assim, oportunidade de verbalizarem aspectos considerados relevantes nas suas vivências pessoais e profissionais.

Ao optarmos pela entrevista semi-directiva, partimos de um quadro temático de referência (ou grelha de temas). Foi elaborado um guião que orientou a nossa intervenção junto dos entrevistados, com temas e tópicos a tratar durante a entrevista, no entanto, foi livre a ordem pela qual os temas foram abordados mas, no caso do entrevistado não abordar espontaneamente determinado tema, foi-lhe proposto esse tema.

As entrevistas foram estruturadas de acordo com o objectivo de estudo, com as questões levantadas e com os nossos pressupostos teóricos. Elaborámos três guiões distintos, um para cada grupo em estudo (grupo de professores, grupo de alunos e grupo de encarregadas de educação). Para a elaboração dos guiões das entrevistas baseamo-nos na orientação dada por Albano Estrela (1986):

1. - formulação do tema;

2. ${ }^{0}$ - definição dos objectivos gerais

3. ${ }^{0}$ - definição dos objectivos de ordem específica e previsão das estratégias de concretização lestas últimas expressas no formulário e nas observações a que o entrevistador deverá atender). As estratégias, independentemente dos seus objectivos e conteúdos específicos, foram definidas a partir de dois princípios de ordem geral: o da autenticidade na relação entrevistador - entrevistado e do controlo da situação por parte do entrevistador, sem perda da autenticidade e da sinceridade da sua postura pessoal. 
O modelo utilizado na construção dos guiões das entrevistas foi semelhante nos três grupos em estudo. Nos quadros seguintes (XIV, XV e XVI), apresentamos os guiões das entrevistas aos professores, aos alunos e às encarregadas de educação, onde se distinguem os objectivos gerais, os blocos e respectivos objectivos específicos, a orientação para questões e as observações.

Elaborámos ainda três grelhas para complementar os guiões das entrevistas, uma para cada grupo em estudo, onde registámos as eventuais perguntas a colocar, de acordo com os blocos e objectivos previamente definidos.

\section{Objectivos gerais da entrevista aos professores:}

- Conhecer as características gerais das turmas que os professores leccionam, identificando certas especificidades relacionadas com as vivências escolares do aluno estrangeiro;

- Conhecer as opiniões dos professores sobre a Educação Intercultural no âmbito das suas práticas pedagógicas;

- Conhecer as opiniões dos professores sobre a importância atribuída à Educação para a Cidadania no exercício profissional, salientando a sua prática em contexto escolar no âmbito do seu trabalho pedagógico;

- Conhecer as opiniões dos professores sobre as consequências da prática da Educação para a Cidadania ao nível do desenvolvimento integral dos alunos.

Quadro XIV - Guião da entrevista aos professores (adaptado de Albano Estrela, 1986)

\begin{tabular}{|c|c|c|c|}
\hline $\begin{array}{l}\text { Designação } \\
\text { dos blocos }\end{array}$ & $\begin{array}{l}\text { Objectivos } \\
\text { específicos }\end{array}$ & Para um formulário de perguntas & Observações \\
\hline $\begin{array}{l}\text { Legitimação da entre- } \\
\text { vista e motivação do } \\
\text { entrevistado }\end{array}$ & $\begin{array}{l}\text { Legitimar a entrevista } \\
\text { e motivar o aluno }\end{array}$ & \begin{tabular}{|c|}
1 - Informar sobre a natureza e objectivos \\
do trabalho. \\
2 - Informar sobre os objectivos da entre- \\
vista. \\
3 - Referir a importância da entrevista \\
para a realização do trabalho. \\
4 - Assegurar a confidencialidade das \\
informações dadas. \\
5 - Pedir autorização para gravar a entre- \\
vista em áudio e permissão para citar \\
na íntegra ou pequenos excertos, os \\
dados recolhidos, garantindo o anoni- \\
mato e assegurando que os dados \\
apenas vão ser utilizados nesta investi- \\
gação.
\end{tabular} & $\begin{array}{l}\text { Tempo médio de duração: } \\
5 \text { a } 10 \text { minutos. Haverá que } \\
\text { responder de forma breve, } \\
\text { precisa e esclarecedora a } \\
\text { todas as perguntas do en- } \\
\text { trevistado, sem desvio dos } \\
\text { objectivos específicos deste } \\
\text { bloco. }\end{array}$ \\
\hline
\end{tabular}




\begin{tabular}{|c|c|c|c|}
\hline $\begin{array}{l}\text { Designação } \\
\text { dos blocos }\end{array}$ & $\begin{array}{l}\text { Objectivos } \\
\text { específicos }\end{array}$ & Para um formulário de perguntas & Observações \\
\hline $\begin{array}{l}\text { Diversidade cultural na } \\
\text { sala de aula }\end{array}$ & $\begin{array}{l}\text { Recolher elementos re- } \\
\text { ferentes à diversidade } \\
\text { cultural dos alunos } \\
\text { dentro da sala de aula. } \\
\text { Conhecer opiniões e } \\
\text { posturas do professor } \\
\text { relativas à diversidade } \\
\text { cultural dentro da sala } \\
\text { de aula. }\end{array}$ & $\begin{array}{l}1 \text { - Solicitar a caracterização da turma em } \\
\text { termos de diversidade cultural. } \\
2 \text { - Conhecer o modo de integração das } \\
\text { crianças estrangeiras no grupo-turma e } \\
\text { os seus rendimentos escolares. } \\
3 \text { - Conhecer a opinião dos professores } \\
\text { sobre a diversidade cultural presente na } \\
\text { sala de aula. } \\
4 \text { - Conhecer estratégias utilizadas pelos } \\
\text { professores para lidar com essa diversi- } \\
\text { dade. } \\
5 \text { - Apurar se a questão da língua é um fac- } \\
\text { tor decisivo para o sucesso escolar de } \\
\text { alunos com origem estrangeira. }\end{array}$ & \multirow{2}{*}{$\begin{array}{l}\text { } \\
\text { Os tópicos expressos neste e } \\
\text { nos seguintes blocos são } \\
\text { pontos de partida para a } \\
\text { construção das perguntas. } \\
\text { O modelo utilizado na entre- } \\
\text { vista será o modelo semi- } \\
\text { directivo. Assim, a entrevista } \\
\text { deverá ser centrada no } \\
\text { entrevistado } \\
\text { Deverá ser fomentada a sua } \\
\text { expressão no que ela tiver } \\
\text { de mais pessoal e autêntico. } \\
\text { para que a perguntas entrevista não } \\
\text { fique compartimentada. }\end{array}$} \\
\hline Educação Intercultural & \begin{tabular}{|l|} 
\\
\\
Recolher elementos \\
referentes à educação \\
intercultural no âmbito \\
da prática pedagógica.
\end{tabular} & \begin{tabular}{|} 
- Conhecer as opiniões dos professores \\
entrevistados sobre a educação inter- \\
cultural. \\
2 - Conhecer modos como os professores \\
entrevistados colocam em prática a \\
Educação Intercultural na sala de aula. \\
3 - Conhecer as opiniões dos professores \\
entrevistados sobre a relação entre \\
a Educação Intercultural e o sucesso \\
escolar dos alunos com culturas diferen- \\
tes lou alunos de origem estrangeira). \\
4 - Conhecer as opiniões dos professores \\
entrevistados sobre o papel da escola na \\
integração da criança estrangeira. \\
5 - Apurar se os professores entrevistados \\
têm conhecimento de orientações/ \\
/directrizes do Ministério da Educação \\
sobre a educação intercultural.
\end{tabular} & \\
\hline $\begin{array}{l}\text { Bloco III } \\
\text { Envolvimento dos pais/ } \\
\text { lencarregados de edu- } \\
\text { cação dos alunos es- } \\
\text { trangeiros com a comu- } \\
\text { nidade escolar }\end{array}$ & \begin{tabular}{|l|} 
Recolher elementos \\
sobre a relação dos \\
pais/encarregados de \\
educação do aluno es- \\
trangeiro com a escola \\
e com o professor.
\end{tabular} & \begin{tabular}{|l}
1 - Conhecer como é a relação dos pais/ \\
/escola e pais/professores. \\
2 - Conhecer as opiniões dos professores \\
sobre o interesse demonstrado pelos \\
pais/encarregados de educação e sobre o \\
apoio prestado pelos pais/encarregados \\
de educação nos trabalhos escolares.
\end{tabular} & \multirow{2}{*}{$\begin{array}{l}\text { Serão também registadas as } \\
\text { reacções não-verbais e as } \\
\text { conotações linguísticas. }\end{array}$} \\
\hline $\begin{array}{l}\text { Educação para a cida- } \\
\text { dania }\end{array}$ & $\begin{array}{l}\text { Conhecer concepções } \\
\text { e opiniões dos profes- } \\
\text { sores entrevistados so- } \\
\text { bre a educação para a } \\
\text { cidadania. }\end{array}$ & $\begin{array}{l}1 \text { - Conhecer concepções de cidadania e de } \\
\text { educação para a cidadania dos profes- } \\
\text { sores entrevistados. } \\
2 \text { - Conhecer as opiniões dos professores } \\
\text { entrevistados sobre a importância da } \\
\text { educação para a cidadania na educação. } \\
3 \text { - Conhecer as opiniões dos professores } \\
\text { entrevistados sobre o papel da escola/ } \\
\text { /professores face a esta temática. }\end{array}$ & \\
\hline
\end{tabular}


(continuação)

\begin{tabular}{|c|c|c|c|}
\hline $\begin{array}{l}\text { Designação } \\
\text { dos blocos }\end{array}$ & $\begin{array}{l}\text { Objectivos } \\
\text { específicos }\end{array}$ & Para um formulário de perguntas & Observações \\
\hline $\begin{array}{l}\text { Bloco V } \\
\text { Práticas pedagógicas } \\
\text { no âmbito da educação } \\
\text { para a cidadania. }\end{array}$ & $\begin{array}{l}\text { Facilitar a expressão } \\
\text { das perspectivas dos } \\
\text { professores entrevista- } \\
\text { dos sobre os aspectos } \\
\text { relacionados com a sua } \\
\text { prática pedagógica. }\end{array}$ & $\begin{array}{l}1 \text { - Conhecer modos de pôr em prática no } \\
\text { contexto escolar a educação para a } \\
\text { cidadania. } \\
2 \text { - Conhecer as opiniões dos professores } \\
\text { entrevistados sobre a relação dos currí- } \\
\text { culos disciplinares e a educação para a } \\
\text { cidadania. } \\
3 \text { - Apurar quais as temáticas que os pro- } \\
\text { fessores entrevistados consideram } \\
\text { mais importantes e relevantes para } \\
\text { abordar. } \\
4 \text { - Conhecer meios e recursos utilizados } \\
\text { para abordar e explorar as temáticas. } \\
5 \text { - Verificar se os entrevistados têm conhe- } \\
\text { cimento de orientações/directrizes do } \\
\text { Ministério da Educação para a educação } \\
\text { para a cidadania. } \\
6 \text { - Apurar se existe necessidade de forma- } \\
\text { ção sobre esta temática por parte dos } \\
\text { professores entrevistados. }\end{array}$ & $\begin{array}{l}\text { Os tópicos expressos neste e } \\
\text { nos seguintes blocos são } \\
\text { pontos de partida para a } \\
\text { construção das perguntas. } \\
0 \text { modelo utilizado na entre- } \\
\text { vista será o modelo semi- } \\
\text { directivo. Assim, a entrevista } \\
\text { deverá ser centrada no } \\
\text { entrevistado } \\
\text { Deverá ser fomentada a sua } \\
\text { expressão no que ela tiver } \\
\text { de mais pessoal e autêntico. } \\
\text { A ligação entre as perguntas } \\
\text { e entre os blocos deverá }\end{array}$ \\
\hline $\begin{array}{l}\text { Bloco VI } \\
\text { Feed-back dos alunos } \\
\text { relativamente à educa- } \\
\text { cão para a cidadania }\end{array}$ & $\begin{array}{l}\text { Conhecer as opiniões } \\
\text { dos professores entre- } \\
\text { vistados sobre o feed- } \\
\text {-back dado pelos alunos } \\
\text { relativamente à educa- } \\
\text { ção para a cidadania. }\end{array}$ & \begin{tabular}{|l} 
- Conhecer as opiniões dos professores \\
entrevistados sobre a importância das \\
aprendizagens no domínio da educação \\
para a cidadania. \\
2 - Determinar possíveis impactos nos alu- \\
nos a nível de atitudes, comportamen- \\
tos, preocupações e envolvimento. \\
3 - Apurar o índice (nível ou grau) da inte- \\
riorização da consciência de cidadania.
\end{tabular} & $\begin{array}{l}\text { Ser telta de forma articulada } \\
\text { para que a entrevista não } \\
\text { fique compartimentada. } \\
\text { Serão também registadas as } \\
\text { reacções não-verbais e as } \\
\text { conotações linguísticas. }\end{array}$ \\
\hline
\end{tabular}

\section{Objectivos gerais da entrevista aos alunos:}

- Saber como sente ou vê a sua escola o aluno de origem estrangeira;

- Conhecer o modo como foi realizada a integração do aluno de origem estrangeira na escola portuguesa;

- Saber se o aluno tem conhecimento de direitos, deveres e valores de cidadania da vida em comum, em contexto escolar e em contexto social;

- Conhecer a opinião do aluno sobre o envolvimento dos pais com a comunidade escolar. 
Quadro XV - Guião da entrevista aos alunos (adaptado de Albano Estrela, 1986)

\begin{tabular}{|c|c|c|c|}
\hline $\begin{array}{l}\text { Designação } \\
\text { dos blocos }\end{array}$ & $\begin{array}{l}\text { Objectivos } \\
\text { específicos }\end{array}$ & Para um formulário de perguntas & Observações \\
\hline $\begin{array}{l}\text { Legitimação da entre- } \\
\text { vista e motivação do } \\
\text { aluno entrevistado }\end{array}$ & $\begin{array}{l}\text { Legitimar a entrevista } \\
\text { e motivar o aluno }\end{array}$ & $\begin{array}{l}1 \text { - Informar, de um modo geral, o aluno } \\
\text { sobre os objectivos da entrevista. } \\
2 \text { - Solicitar a ajuda do aluno entrevistado, } \\
\text { na medida em que as suas informações } \\
\text { são absolutamente necessárias para o } \\
\text { bom êxito do nosso trabalho. } \\
3 \text { - Assegurar o carácter confidencial des- } \\
\text { sas informacões. }\end{array}$ & $\begin{array}{l}\text { Tempo médio de duração: } \\
3 \text { minutos. Haverá que res- } \\
\text { ponder de modo esclarece- } \\
\text { dor a todas as dúvidas do } \\
\text { aluno sobre a entrevista } \\
\text { sem desvios dos objectivos } \\
\text { específicos deste bloco. }\end{array}$ \\
\hline Actividades escolares & $\begin{array}{l}\text { Recolher elementos } \\
\text { referentes às activida- } \\
\text { des escolares dos alu- } \\
\text { nos. }\end{array}$ & $\begin{array}{l}1 \text { - Conhecer as razões do aluno para gos- } \\
\text { tar ou não de frequentar a escola. } \\
2 \text { - Determinar quais são as actividades } \\
\text { escolares que o aluno mais gosta e } \\
\text { quais as actividades que ele gostaria de } \\
\text { desenvolver na escola. } \\
3 \text { - Conhecer o que significa para o aluno } \\
\text { «aprender». } \\
4 \text { - Conhecer o rendimento escolar do } \\
\text { aluno. } \\
5 \text { - Apurar se em contexto escolar é usual } \\
\text { referir-se aos seus hábitos e costumes } \\
\text { do país de origem. } \\
6 \text { - Conhecer a opinião do aluno sobre «coi- } \\
\text { sas boas» e «menos boas» que aconte- } \\
\text { cem na escola. }\end{array}$ & \multirow{4}{*}{$\begin{array}{l}\text { - } \\
\text { Os tópicos expressos neste e } \\
\text { nos seguintes blocos são } \\
\text { pontos de partida para a } \\
\text { construção das perguntas. } \\
\text { O modelo utilizado na entre- } \\
\text { vista será o modelo semi- } \\
\text { directivo. Assim, a entrevista } \\
\text { deverá ser centrada no } \\
\text { aluno. } 0 \text { entrevistador não } \\
\text { deverá interromper o aluno, } \\
\text { mas fomentar a sua expres- } \\
\text { são. } \\
\text { A ligação entre as perguntas } \\
\text { a entre os blocos deverá } \\
\text { asectuar-se de modo arti- } \\
\text { culado de modo a que a } \\
\text { entrevista não assuma a a } \\
\text { forma de um interrogatório } \\
\text { rígido. }\end{array}$} \\
\hline $\begin{array}{l}\text { Bloco II } \\
\text { Relações interpessoais }\end{array}$ & $\begin{array}{l}\text { Conhecer característi- } \\
\text { cas do relacionamento } \\
\text { do aluno com colegas } \\
\text { e professores. }\end{array}$ & $\begin{array}{l}1 \text { - Conhecer o modo como o aluno se rela- } \\
\text { ciona com os colegas. } \\
2 \text { - Apurar as dificuldades ou facilidades } \\
\text { sentidas no primeiro contacto com os } \\
\text { colegas e com a escola } \\
3 \text { - Conhecer o modo como o aluno se rela- } \\
\text { ciona com o professor. }\end{array}$ & \\
\hline $\begin{array}{l}\text { Desenvolvimento da } \\
\text { consciência cívica }\end{array}$ & \begin{tabular}{|l|} 
Facilitar a expressão \\
dos alunos entrevista- \\
dos sobre direitos, \\
deveres e valores de \\
cidadania da vida em \\
comum em contexto \\
escolar e em contextos \\
sociais.
\end{tabular} & $\begin{array}{l}1 \text { - Saber se o aluno tem conhecimento de } \\
\text { direitos e deveres e valores de cidadania } \\
\text { da vida em sociedade. } \\
2 \text { - Saber se o aluno conhece os seus direi- } \\
\text { tos e deveres como aluno da instituição } \\
\text { escolar. } \\
3 \text { - Determinar o grau de envolvimento e } \\
\text { participação do aluno na «elaboração» } \\
\text { desses direitos e deveres. } \\
4 \text { - Saber se o aluno participa em dis- } \\
\text { cussões de problemas da vida em socie- } \\
\text { dade, em contexto escolar. }\end{array}$ & \\
\hline $\begin{array}{l}\text { Envolvimento dos pais/ } \\
\text { lencarregados de edu- } \\
\text { cação com a comuni- } \\
\text { dade escolar }\end{array}$ & $\begin{array}{l}\text { Recolher elementos } \\
\text { que permitam conhe- } \\
\text { cer as opiniões dos alu- } \\
\text { nos relativamente ao } \\
\text { envolvimento dos pais } \\
\text { com a comunidade } \\
\text { escolar }\end{array}$ & $\begin{array}{l}1 \text { - Conhecer a opinião dos alunos entrevis- } \\
\text { tados relativamente às razões porque } \\
\text { os pais gostam ou não que frequentem } \\
\text { a escola. } \\
2 \text { - Apurar se os alunos têm apoio na reali- } \\
\text { zação dos trabalhos em casa e de que } \\
\text { modo é dado esse apoio. } \\
3 \text { - Determinar se os pais dos alunos visi- } \\
\text { tam com muita ou pouca frequência } \\
\text { a escola e o porquê das suas visitas. } \\
4 \text { - Conhecer a língua que os alunos entre- } \\
\text { vistados falam em casa. }\end{array}$ & \\
\hline
\end{tabular}




\section{Objectivos gerais da entrevista às encarregadas de educação:}

- Conhecer o percurso de imigração dos pais/encarregada de educação do aluno estrangeiro;

- Conhecer as suas opiniões relativamente ao processo educativo do seu educando no nosso país;

- Conhecer o modo como se envolve com a comunidade escolar.

\section{Quadro XVI - Guião da entrevista às encarregadas de educação (adaptado de Albano Estrela, 1986)}

\begin{tabular}{|c|c|c|c|}
\hline $\begin{array}{l}\text { Designação } \\
\text { dos blocos }\end{array}$ & $\begin{array}{l}\text { Objectivos } \\
\text { específicos }\end{array}$ & Para um formulário de perguntas & Observações \\
\hline $\begin{array}{l}\text { Legitimação da entre- } \\
\text { vista e motivação da } \\
\text { entrevistada }\end{array}$ & $\begin{array}{l}\text { Legitimar a entrevista } \\
\text { e motivar a entrevista- } \\
\text { da }\end{array}$ & $\begin{array}{l}1 \text { - Informar, de um modo geral, o entrevis- } \\
\text { tado sobre a natureza e os objectivos da } \\
\text { entrevista. } \\
2 \text { - Informar sobre os objectivos da entre- } \\
\quad \text { vista. } \\
3 \text { - Referir a importância da entrevista para } \\
\text { a realização do trabalho. } \\
4 \text { - Assegurar a confidencialidade das infor- } \\
\text { mač̃es dadas. } \\
5 \text { - Solicitar a permissão para citar, na ínte- } \\
\text { gra ou pequenos excertos, o seu discurso. }\end{array}$ & $\begin{array}{l}\text { Tempo médio de duração: } \\
5 \text { a } 10 \text { minutos. Haverá que } \\
\text { responder de modo esclare- } \\
\text { cedor a todas as dúvidas da } \\
\text { entrevistada, sem desvios } \\
\text { dos objectivos específicos } \\
\text { deste bloco. }\end{array}$ \\
\hline $\begin{array}{l}\text { Bloco I } \\
\text { Percurso de imigração }\end{array}$ & $\begin{array}{l}\text { Obter dados relativos } \\
\text { ao percurso pessoal da } \\
\text { entrevistada no proces- } \\
\text { so de imigração }\end{array}$ & $\begin{array}{l}1 \text { - Saber há quanto tempo se encontra em } \\
\text { Portugal e o motivo da sua vinda. } \\
2 \text { - Conhecer a composição do seu agrega- } \\
\text { do familiar e a forma como os seus ele- } \\
\text { mentos realizaram o processo de imi- } \\
\text { gração. } \\
3 \text { - Conhecer o modo como foi feita a sua } \\
\text { integração no nosso país. } \\
4 \text { - Saber qual a língua que falam em casa } \\
\text { com o filho. }\end{array}$ & \multirow{2}{*}{$\begin{array}{l}\text { Os tópicos expressos neste e } \\
\text { nos seguintes blocos são } \\
\text { pontos de partida para a } \\
\text { construção das perguntas. } \\
\text { O modelo utilizado na entre- } \\
\text { vista será o modelo semi- } \\
\text { directivo. Assim, a entrevista } \\
\text { deverá ser centrada na } \\
\text { entrevistada. }\end{array}$} \\
\hline $\begin{array}{l}\text { Bloco II } \\
\text { Interesse pelo proces- } \\
\text { so educativo do seu } \\
\text { educando }\end{array}$ & $\begin{array}{l}\text { Conhecer a opinião do } \\
\text { entrevistado em rela- } \\
\text { ção ao processo de } \\
\text { ensino/aprendizagem } \\
\text { do seu educando. }\end{array}$ & $\begin{array}{l}1 \text { - Saber se presta apoio ao seu educando } \\
\text { nos trabalhos escolares e de que forma } \\
\text { o faz. } \\
2 \text { - Apurar as razões porque gosta ou não } \\
\text { que o seu educando frequente a escola } \\
\text { portuguesa. }\end{array}$ & \\
\hline $\begin{array}{l}\text { Bloco III } \\
\text { Envolvimento com a } \\
\text { comunidade escolar }\end{array}$ & $\begin{array}{l}\text { Facilitar a expressão } \\
\text { das perspectivas do } \\
\text { entrevistado sobre o } \\
\text { processo de integração } \\
\text { no meio escolar do seu } \\
\text { educando. }\end{array}$ & $\begin{array}{l}3 \text { - Conhecer a relação encarregado de } \\
\text { educação/professor. } \\
4 \text { - Saber a frequência das visitas à escola e } \\
\text { as suas razóes. } \\
5 \text { - Auscultar a opinião do encarregado de } \\
\text { educação sobre a integração do seu } \\
\text { educando na escola relativamente a: } \\
\text { - relação educando/colegas/professor; } \\
\text { atenção e apoio dispensado ao edu- } \\
\text { cando; parecer sobre a forma como } \\
\text { foi feita a sua integração na escola; } \\
\text { medidas que poderiam ser postas em } \\
\text { prática na escola para uma melhor } \\
\text { integração. } \\
6 \text { - No caso do seu educando ter frequenta- } \\
\text { do uma instituição escolar no país de } \\
\text { origem, apurar diferenças e semelhan- } \\
\text { ças que o encarregado de educação } \\
\text { encontra entre essa instituição e a esco- } \\
\text { la portuguesa. }\end{array}$ & $\begin{array}{l}\text { Deverá ser fomentada a sua } \\
\text { expressão no que ela tiver } \\
\text { de mais pessoal e autêntico. } \\
\text { A ligação entre as perguntas } \\
\text { e entre os blocos deverá ser } \\
\text { feita de forma articulada } \\
\text { para que a entrevista não } \\
\text { fique compartimentada. } \\
\text { Serão também registadas as } \\
\text { reacções não-verbais e as } \\
\text { conotações linguísticas. }\end{array}$ \\
\hline
\end{tabular}




\section{A APLICAC̣ÃO DAS ENTREVISTAS}

Pretendeu-se utilizar na condução das entrevistas uma orientação semidirectiva, sem prejuízo de uma anterior estruturação em termos de objectivos gerais e específicos. Privilegiámos a entrevista oral e gravada como instrumento de recolha de informação, tentando não criar uma situação artificial de investigação. Deste modo, todas as entrevistas foram gravadas, após o consentimento dos entrevistados, e todo o seu conteúdo foi posteriormente transcrito.

Nas entrevistas ao grupo de professores, foi aplicada uma primeira entrevista, de modo a proceder à testagem do guião, a um sujeito com características idênticas aos sujeitos da amostra, que funcionou como experiência piloto antes de passar às entrevistas definitivas. Para além de servir para evitar erros futuros na aplicação das entrevistas, esta experiência piloto serviu também para treino da investigadora e, para um possível refinamento do guião (reformulação das questões e reajustamento do guião). Porém, dada a riqueza do seu conteúdo decidimos incluí-la no corpus.

No entanto, para os outros dois grupos lalunos e encarregadas de educação) optámos por não realizar uma entrevista piloto dada a dificuldade em encontrar sujeitos com características semelhantes aos da nossa amostra.

\subsection{Ao grupo de professores}

A entrevista foi centrada no professor entrevistado. Ao longo da entrevista procurou-se fomentar a sua expressão, deixando-o exprimir-se pelas suas próprias palavras e ao seu ritmo pessoal, não o interrompendo e evitando cortar-lhe a palavra e assumindo também uma atitude de escuta. Apesar de pretendermos que as entrevistas se desenrolassem em clima informal e descontraído, nunca esquecemos os aspectos fundamentais considerados no guião. O clima de proximidade que se estabeleceu, conduziu a que os entrevistados não se sentissem simples objecto de pesquisa, mas elementos pares do diálogo. Após a entrevista, considerámos útil registar observações sobre o comportamento verbal e não verbal do entrevistado e sobre o ambiente em que a entrevista decorreu.

As entrevistas foram codificadas de acordo com a ordem de realização, por exemplo, a entrevista número um é designada por $\mathbf{P 1}$ e assim sucessivamente. À codificação das entrevistas foi também atribuída uma letra, 
no caso de ser um professor com um aluno proveniente de países do leste europeu foi-lhe dada a letra $\mathbf{L}$; no caso de ser um professor com um aluno brasileiro foi-lhe dada a letra $\mathbf{B}$.

\subsection{Ao grupo de alunos}

Convém salientar alguns aspectos singulares na condução da entrevista com as crianças. Assim, e de acordo com Albano Estrela (1986:358), a entrevista deverá assentar numa atitude de simpatia activa situada «num plano dinâmico, de ir ao encontro do outro, aceitando-o enquanto pessoa e expressando-lhe o nosso interesse pelos seus problemas» e revelando curiosidade e até admiração pela informação dada.

Quando verificávamos que a criança não percebia a pergunta que the era dirigida, tentávamos reformular a pergunta por outras palavras, para que a criança a entendesse. Quando as crianças tinham tendência para responder «não sei» ou ficavam caladas durante algum tempo, depois de ter sido formulada a pergunta lesta situação verificou-se quase exclusivamente nos alunos do $1 .^{\circ}$ ano de escolaridade), incitávamo-las a responder, por vezes repetindo novamente a pergunta. Devemos, ainda, salientar que as posturas que assumíamos perante a criança foram no sentido de a colocarmos a mais descontraída possível.

Na codificação das entrevistas aos alunos optou-se por criar dois grupos, o grupo das crianças de países de Leste (identificadas com a letra L) e o grupo das crianças oriundas do Brasil (identificadas com a letra B). Dentro de cada grupo, as entrevistas foram codificadas de acordo com a ordem de realização, por exemplo, a primeira entrevista do grupo das crianças de Leste é designada por $\mathbf{A} \mathbf{1} \mathbf{L}$ e assim sucessivamente, a primeira entrevista do grupo das crianças brasileiras é designada por A1B e assim sucessivamente.

\subsection{Ao grupo de encarregadas de educação}

No que diz respeito às entrevistas com as encarregadas de educação imigrantes de países do leste europeu pensámos que a questão da língua poderia influenciar negativamente o desenrolar da entrevista, mas constatámos que isso não se verificou. Algumas dessas entrevistadas, logo no início da entrevista, referiam o facto de ainda não dominarem bem o uso da língua portuguesa, e colocavam em dúvida que conseguissem responder às questões que lhes iriam ser colocadas. No entanto, a questão da 
língua não foi um factor impeditivo do desenrolar da entrevista, pois sempre que a entrevistada não compreendia a pergunta que the era dirigida procurávamos reformular a pergunta por outras palavras, utilizando uma linguagem mais simples e acessível, motivando a entrevistada a responder. Deste modo, estabeleceu-se um diálogo entre entrevistadora e entrevistada que permitiu a recolha de uma auto-reflexão e de uma subjectividade dos percursos de vida e vivências de todas as entrevistadas, levando também ao discernimento de novas dimensões de análise para além das estipuladas inicialmente no guião da entrevista.

Na codificação das entrevistas às encarregadas de educação optou-se pela utilização dos mesmos critérios usados para a codificação das entrevistas aos alunos. Assim, criaram-se dois grupos, o grupo das encarregadas de educação de países de Leste (identificadas com a letra L) e o grupo das encarregadas de educação oriundos do Brasil lidentificadas com a letra $\mathbf{B}$ ).

Dentro de cada grupo, as entrevistas foram codificadas de acordo com a ordem de realização, por exemplo, a primeira entrevista do grupo de encarregadas de educação de Leste é designada por A1L e assim sucessivamente; a primeira entrevista do grupo de encarregadas de educação brasileiras é designada por A1B e assim sucessivamente.

Depois de finalizadas as entrevistas concluímos que a nossa investigação empírica nos facultou um contacto ainda maior do que aquele que já possuíamos, como docentes do 1. $\mathrm{CEB}$, com os problemas reais da educação, quer por parte dos professores, quer por parte das minorias imigrantes na voz dos alunos e na voz dos seus encarregados de educação. Foi uma experiência enriquecedora e gratificante a nível pessoal, teórico e metodológico e a nível prático.

Depois de termos perante nós todo o material recolhido, definimos os critérios de notação das transcrições das entrevistas e iniciámos a tarefa de o organizar com base num plano por nós encontrado que ajudasse essa organização, permitindo uma fácil leitura.

\section{A ANÁLISE DE CONTEÚDO COMO MEIO PARA A CONSTRUC̣ÃO DE CONHECIMENTO}

Na fase da investigação empírica deste trabalho, aplicámos a análise de conteúdo como processo metodológico de análise dos dados recolhidos através das entrevistas semi-directivas aos professores, alunos 
e encarregados de educação. A análise de conteúdo oferece-nos a possibilidade «de tratar de forma metódica informações e testemunhos que apresentam um certo grau de profundidade e de complexidade, como, por exemplo, os relatórios de entrevistas pouco directivas « (Quivy e Campenhoudt, 1998:227). Esta técnica de análise «permite inferências sobre a fonte, a situação em que esta produziu o material objecto de análise» (Vala, 1986:104). É, portanto, nosso objectivo analisar todo o material recolhido e tentar compreender os significados que os entrevistados quiseram atribuir, procurando desocultar os sentidos implícitos e os sentidos latentes, de uma forma interpretativa.

No decorrer da entrevista, tentámos fazer aparecer o máximo de elementos de informação e de reflexão, que serviram de materiais para a análise de conteúdo realizada. Ao efectuar a análise de conteúdo foi nossa intenção fazer com que correspondesse às «exigências de explicitação, de estabilidade e de intersubjectividade dos processos» (Quivy e Campenhoudt, 1998:195). Concordamos com estes autores quando referem que a reconstituição das realidades passadas baseadas em representações, sensibilidades, mentalidades, ideologias e atitudes exige uma interpretação rigorosa e cuidada, que permita apreender o significado dos dados de pesquisa. Salientamos que, na análise de conteúdo realizada, não tínhamos como objectivo quantificar ou medir variáveis, mas sim, extrair inferências e realizar interpretações válidas dos discursos obtidos nas entrevistas efectuadas. Foi nossa intenção interpretar o discurso dos entrevistados de um modo adequado, válido e pertinente.

Começámos o nosso trabalho de análise das entrevistas seguindo algumas etapas por nós definidas a partir das leituras realizadas às diversas perspectivas para o desenvolvimento do processo de análise de conteúdo de diferentes autores, mas tendo como referência, essencialmente, Bardin (1995) e L'Écuyer (referido por Leite, 2002). Expomos, em seguida, essas etapas:

1. ${ }^{\text {a }}$ etapa - leituras iniciais do texto da entrevista com o objectivo de contactar com o conteúdo, apreender as suas características e encontrar o sentido geral;

2. ${ }^{\text {a }}$ etapa - identificação das ideias principais expressas no texto da entrevista (ideias e frases com significado) e avaliação das possibilidades de análise (previsão do tipo de unidades de análise a utilizar e apreensão de certas singularidades que poderão dar origem às categorias - categorias emergentes; 
3. ${ }^{a}$ etapa - selecção das unidades de análise para conseguir retirar do discurso elementos com um sentido completo referente aos objectivos de análise de conteúdo.

Neste processo, consideraram-se as unidades de contexto para assegurar «a fidelidade e a validade da análise» (Vala, 1986:114), a partir das quais se definiram as unidades de registo (segmento mínimo de conteúdo que se considera necessário para poder proceder à análise, colocando-o numa determinada categoria). Optámos por realizar uma análise temática, descobrindo os «núcleos de sentido» (Bardin, 1995:105) significativos para a nossa análise. Deste modo, e após as numerosas leituras realizadas, tornou-se para nós visível que era a «unidade de sentido» a mais apropriada, pois ao optar-se pela sua classificação, o texto não é segmentado, nem em frases, nem em palavras, mas em partes que transmitem uma ideia significativa e válida para a nossa análise. Após a escolha das unidades de análise -unidades de sentido, «que transmitem um sentido completo relativo aos objectivos de análise» (Leite, 2002:274) estabelecemos as dimensões de análise para cada grupo em estudo.

\section{Quadro XVII - Dimensões de análise das entrevistas aos professores}

\begin{tabular}{|c|c|c|c|c|c|}
\hline \multicolumn{9}{|c|}{ Dimensões de análise } \\
\hline $\begin{array}{c}\text { Apreciação } \\
\text { da diversidade } \\
\text { cultural } \\
\text { presente na } \\
\text { sala de aula }\end{array}$ & $\begin{array}{c}\text { Envolvimento dos } \\
\text { pais/encarregadas } \\
\text { de educação } \\
\text { de alunos } \\
\text { intercultural } \\
\text { estrangeiros com } \\
\text { a comunidade } \\
\text { escolar }\end{array}$ & $\begin{array}{c}\text { Educação } \\
\text { para } \\
\text { a cidadania }\end{array}$ & $\begin{array}{c}\text { Práticas } \\
\text { pedagógicas } \\
\text { no âmbito da } \\
\text { educação para } \\
\text { a cidadania }\end{array}$ & $\begin{array}{c}\text { Feed-back dos educação } \\
\text { alua } \\
\text { para a } \\
\text { cidadania }\end{array}$ \\
\hline
\end{tabular}

Quadro XVIII - Dimensões de análise das entrevistas aos alunos

\begin{tabular}{|c|c|c|c|}
\hline \multicolumn{3}{|c|}{ Dimensões de análise } \\
\hline Actividades escolares & Relações interpessoais & $\begin{array}{c}\text { Envolvimento } \\
\text { Desenvolvimento de } \\
\text { competências cívicas }\end{array}$ & $\begin{array}{c}\text { dos pais/encarregadas } \\
\text { de educação com } \\
\text { a comunidade escolar }\end{array}$ \\
\hline
\end{tabular}

Quadro XIX - Dimensões de análise das entrevistas às encarregadas de educação

\begin{tabular}{|c|c|c|}
\hline \multicolumn{3}{|c|}{ Dimensões de análise } \\
\hline Percurso de imigração & $\begin{array}{c}\text { Interesse pelo processo educativo } \\
\text { do seu educando }\end{array}$ & $\begin{array}{c}\text { Envolvimento com a comunidade } \\
\text { escolar }\end{array}$ \\
\hline
\end{tabular}


4. ${ }^{a}$ etapa - definição das categorias e subcategorias de análise, em função das quais o conteúdo das entrevistas foi classificado, e levantamento dos seus indicadores presentes no texto das entrevistas, pois «cada categoria é definida operacionalmente pelos seus indicadores, a cujo levantamento se deve proceder exaustivamente» (Estrela, 1986:468), para registo em quadros de análise.

Apesar de inicialmente certas questões e preocupações terem dado sugestões para a criação de algumas das categorias, a maior parte das categorias e subcategorias definidas surgiram a partir do discurso expresso nas entrevistas, «de maneira indutiva, a partir das semelhanças do sentido do material» (Landry, 1992 cit. por Leite, 2002:269). Assim, podemos considerar a nossa análise, essencialmente, um «procedimento exploratório» (Carmo e Ferreira, 1998:255). Também tentámos, neste ponto do trabalho, ao seleccionar as categorias, que estas possuíssem as qualidades necessárias, de modo a garantir a validade e a fidelidade dos dados obtidos. L'Écuyer (1990, cit. por Leite, 2002:273) defende que «o valor de uma análise de conteúdo depende das categorias a que recorre» e que «elas devem possuir determinadas qualidades ou exigências que permitam pôr em evidência o sentido do fenómeno analisado». A partir da análise de algumas tipologias apresentadas por outros autores $^{10}$, L'Écuyer diz-nos que as categorias devem possuir sete qualidades «mas em vez de mutuamente exclusivas e objectivas, devem, respectivamente, possuir todas as suas partes constituintes relacionadas por uma referência lógica e serem inteligíveis a vários codificadores» (Leite, 2002:273). Concordamos com este autor quando defende que «o princípio da exclusividade elimina relações reais entre elementos no texto; a classificação de um mesmo enunciado simultaneamente em duas categorias melhora a análise das relações existentes entre os diferentes elementos do fenómeno estudado; a razão de ser das categorias é juntar o que tem o mesmo sentido, e não as mesmas palavras, frases ou enunciados; a perda de sentido em que se incorre pelo cumprimento do princípio da exclusividade torna difícil vê-lo como um meio de salvaguardar a 'objectividade' da análise de conteúdo» (L'Écuyer cit. por Leite, 2002:271). Assim, na nossa análise adoptámos o princípio da não exclusividade por constatarmos que um mesmo enunciado era relevante em mais que uma categoria.

10. Após uma análise realizada aos trabalhos de alguns autores (d'Unrug (1974), Mucchielli (1979) e Bardin (1977)), L'Écuyer faz uma síntese dizendo que, e de acordo com esses autores, as categorias devem possuir sete qualidades: homogéneas, pertinentes, claramente definidas, objectivas, produtivas, mutuamente exclusivas e serem simultaneamente exaustivas e em número limitado. 
Consideramos que a nossa primeira tentativa para atribuir as categorias aos dados constituiu um teste da viabilidade das categorias criadas. No decorrer deste processo algumas categorias foram aperfeiçoadas e afinadas tornando-se, deste modo, mais adequadas ao conteúdo das respostas obtidas. Tentámos também desenvolver um sistema categorial com um número limitado de categorias que categorizaram a informação a vários níveis: as categorias principais, mais gerais e abrangentes, agrupavam um leque variado de actividades, atitudes, opiniões e comportamentos; as subcategorias dividiam os códigos principais em categorias mais pequenas (quadros XX, XXI e XXII). Depois de ter definido as categorias e as subcategorias foi atribuída a cada uma delas, uma abreviatura para facilitar a memorização do sistema de codificação. Em seguida, percorreram-se todos os dados, marcando cada indicador correspondente a uma unidade de registo (núcleo de sentido) com o código da categoria e/ou da subcategoria apropriada.

\section{Quadro XX - Sistema categorial das entrevistas aos professores}

\begin{tabular}{|c|c|}
\hline Dimensões de análise & Categorias/Subcategorias \\
\hline $\begin{array}{l}\text { Bloco I } \\
\text { Apreciação da diversi- } \\
\text { dade cultural presente } \\
\text { na sala de aula }\end{array}$ & $\begin{array}{l}\text { Diversidade cultural } \\
\text { Presença de crianças estrangeiras na sala de aula } \\
\text { Integração da criança estrangeira na sala/escola } \\
\text { Rendimento escolar da criança estrangeira } \\
\text { Postura do professor. } \\
\text { Dificuldades sentidas perante a diversidade } \\
\text { A língua como factor decisivo para o sucesso escolar do aluno com origem } \\
\text { estrangeira }\end{array}$ \\
\hline \multirow{3}{*}{$\begin{array}{l}\text { Bloco II } \\
\text { Educação Intercultural }\end{array}$} & $\begin{array}{l}\text { Opinião do professor sobre a Educação Intercultural } \\
\text { Definição de Educação Intercultural } \\
\text { Formas de colocar em prática a Educação Intercultural } \\
\text { A Educação Intercultural e o sucesso escolar dos alunos com culturas diferentes }\end{array}$ \\
\hline & $\begin{array}{l}\text { Conhecimento de orientações/directrizes do Ministério da Educação } \\
\text { Desconhecimento } \\
\text { Conhecimento }\end{array}$ \\
\hline & $\begin{array}{l}\text { Responsabilidade da escola na integração da criança estrangeira } \\
\text { Muita responsabilidade } \\
\text { Pouca responsabilidade. } \\
\text { Igual responsabilidade para com alunos portugueses e alunos estrangeiros }\end{array}$ \\
\hline $\begin{array}{l}\text { Bloco III } \\
\text { Envolvimento dos pais/ } \\
\text { lencarregados de edu- } \\
\text { cação com a comuni- } \\
\text { dade escolar }\end{array}$ & $\begin{array}{l}\text { Opinião dos professores sobre a relação pais/encarregados de educação } \\
\text { e escola } \\
\text { Relação pais/enc. de educação e professor } \\
\text { Interesse e apoio nas actividades escolares }\end{array}$ \\
\hline
\end{tabular}


(continuação)

\begin{tabular}{|c|c|}
\hline Dimensões de análise & Categorias/Subcategorias \\
\hline \multirow{2}{*}{$\begin{array}{l}\text { Bloco IV } \\
\text { Educação para a cida- } \\
\text { dania }\end{array}$} & $\begin{array}{l}\text { Concepção da cidadania } \\
\text { Definição de cidadania } \\
\text { Definição de educação para a cidadania }\end{array}$ \\
\hline & $\begin{array}{l}\text { Importância da educação para a cidadania } \\
\text { Papel da educação para a cidadania } \\
\text { Responsabilidade e papel da escola/professor na educação para a cida- } \\
\text { dania }\end{array}$ \\
\hline \multirow{9}{*}{$\begin{array}{l}\text { Bloco V } \\
\text { Práticas pedagógicas } \\
\text { no âmbito da educação } \\
\text { para a cidadania }\end{array}$} & $\begin{array}{l}\text { Formas de colocar em prática a educação para a cidadania } \\
\text { Via da formação transversal } \\
\text { Desenvolvimento de um projecto de natureza interdisciplinar } \\
\text { Situação concreta } \\
\text { Datas/dias comemorativos } \\
\text { Área de formação cívica }\end{array}$ \\
\hline & Contributo dos currículos disciplinares \\
\hline & Temas mais importantes \\
\hline & $\begin{array}{l}\text { O respeito e a valorização da diversidade cultural } \\
\text { O autoconhecimento }\end{array}$ \\
\hline & $\begin{array}{l}\text { Os direitos, os deveres e as responsabilidades sociais, os valores da cida- } \\
\text { dania } \\
0 \text { ambiente, a ecologia (física e humana), a saúde }\end{array}$ \\
\hline & Meios/recursos utilizados \\
\hline & $\begin{array}{l}\text { Conhecimento de orientações/directrizes do Ministério da Educação para } \\
\text { a educação para a cidadania } \\
\text { Algum conhecimento } \\
\text { Conhecimento }\end{array}$ \\
\hline & Formação contínua \\
\hline & $\begin{array}{l}\text { Não sente necessidade de formação } \\
\text { Sente necessidade de formação }\end{array}$ \\
\hline \multirow{4}{*}{$\begin{array}{l}\text { Bloco VI } \\
\text { Feedback dos alunos } \\
\text { relativo à educação } \\
\text { para a cidadania }\end{array}$} & Importância das aprendizagens \\
\hline & Impacto nos alunos \\
\hline & $\begin{array}{l}\text { Mudança de atitudes/comportamentos } \\
\text { Preocupação/envolvimento }\end{array}$ \\
\hline & $\begin{array}{l}\text { Índice da consciência cívica } \\
\text { Nível bom } \\
\text { Nível médio }\end{array}$ \\
\hline
\end{tabular}


Quadro XXI - Sistema categorial das entrevistas aos alunos

\begin{tabular}{|c|c|}
\hline Dimensões de análise & Categorias/Subcategorias \\
\hline \multirow{7}{*}{$\begin{array}{l}\text { Bloco I } \\
\text { Actividades escolares }\end{array}$} & $\begin{array}{l}\text { Gosto pela frequência da escola } \\
\text { Razões para gostar de frequentar a escola }\end{array}$ \\
\hline & Actividades escolares que mais gosta de realizar \\
\hline & $\begin{array}{l}\text { Actividades que gostaria de realizar } \\
\text { Sugere actividades } \\
\text { Não sugere actividades }\end{array}$ \\
\hline & \begin{tabular}{|l|} 
Acontecimentos escolares \\
Bons acontecimentos \\
Acontecimentos menos bons \\
\end{tabular} \\
\hline & $\begin{array}{l}\text { Significado de aprender } \\
\text { A integração no nosso país } \\
\text { Trabalho no futuro } \\
\text { Saber mais }\end{array}$ \\
\hline & \begin{tabular}{|l|} 
Rendimento escolar \\
Bom rendimento \\
Rendimento satisfatório \\
\end{tabular} \\
\hline & $\begin{array}{l}\text { Referência a hábitos e costumes do país de origem } \\
\text { Muitas vezes ou algumas } \\
\text { Nunca }\end{array}$ \\
\hline \multirow{2}{*}{$\begin{array}{l}\text { Bloco II } \\
\text { Relações interpessoais }\end{array}$} & $\begin{array}{l}\text { Relação com os colegas } \\
\text { Boa relação } \\
\text { Relação menos boa } \\
\text { Dificuldades sentidas no relacionamento com os colegas } \\
\end{array}$ \\
\hline & $\begin{array}{l}\text { Relação com o professor } \\
\text { Boa relação } \\
\text { Relação menos boa } \\
\end{array}$ \\
\hline \multirow[t]{2}{*}{$\begin{array}{l}\text { Bloco III } \\
\text { Desenvolvimento de } \\
\text { competências cívicas }\end{array}$} & $\begin{array}{l}\text { Conhecimento de direitos e deveres da vida em comum } \\
\text { Deveres do aluno em meio escolar } \\
\text { Deveres do aluno na vida em sociedade } \\
\text { Direitos do aluno em meio escolar } \\
\text { Envolvimento do aluno na elaboração e determinação desses direitos } \\
\text { e deveres }\end{array}$ \\
\hline & Discussão de problemas da vida em sociedade \\
\hline \multirow{5}{*}{$\begin{array}{l}\text { Bloco IV } \\
\text { Envolvimento dos pais/ } \\
\text { /encarregados de edu- } \\
\text { cação com a comuni- } \\
\text { dade escolar }\end{array}$} & $\begin{array}{l}\text { Opinião dos alunos sobre as razões pelas quais os pais/encarregados de } \\
\text { educação gostam que eles frequentem a escola }\end{array}$ \\
\hline & $\begin{array}{l}\text { Aprendizagem da leitura e da escrita } \\
\text { Obtenção de novos conhecimentos e interiorização de regras } \\
\text { Convivência com colegas e amigos } \\
\text { Perspectiva futura da frequência da escola }\end{array}$ \\
\hline & $\begin{array}{l}\text { Apoio na realização dos trabalhos de casa } \\
\text { Prestam apoio } \\
\text { Não prestam apoio }\end{array}$ \\
\hline & $\begin{array}{l}\text { Contactos estabelecidos pelos pais/encarregados de educação com a } \\
\text { escola } \\
\text { Com alguma frequência } \\
\text { Com pouca frequência }\end{array}$ \\
\hline & Língua falada em casa pelas crianças de países do leste europeu \\
\hline
\end{tabular}


Quadro XXII - Sistema categorial das entrevistas às encarregadas de educação

\begin{tabular}{|c|c|}
\hline Dimensões de análise & Categorias/Subcategorias \\
\hline \multirow{5}{*}{ Bloco I } & Anos de permanência em Portugal \\
\hline & Motivo da vinda para Portugal \\
\hline & Composição do agregado familiar \\
\hline & Chegada a Portugal \\
\hline & $\begin{array}{l}\text { Integração no nosso país } \\
\text { Dificuldades sentidas } \\
\text { Facilidades sentidas } \\
\text { Língua falada em casa }\end{array}$ \\
\hline \multirow{2}{*}{$\begin{array}{l}\text { Bloco II } \\
\text { Interesse pelo proces- } \\
\text { so educativo do seu } \\
\text { educando }\end{array}$} & $\begin{array}{l}\text { Apoio prestado nos trabalhos de casa } \\
\text { Tem tempo disponível para prestar apoio } \\
\text { Tem pouco tempo disponível para prestar apoio } \\
\text { Modo de prestar apoio }\end{array}$ \\
\hline & $\begin{array}{l}\text { Razões pelas quais gosta que o seu educando frequente a escola } \\
\text { Importância da educação } \\
\text { Satisfação do educando } \\
\text { Interesse/exigência das professoras (a) }\end{array}$ \\
\hline \multirow{3}{*}{$\begin{array}{l}\text { Bloco III } \\
\text { Envolvimento com a } \\
\text { comunidade escolar }\end{array}$} & $\begin{array}{l}\text { Contactos com a professora (a) do seu educando } \\
\text { Vai à escola por iniciativa própria e quando é solicitada } \\
\text { Só vai à escola quando é solicitada } \\
\text { Nem sempre comparece, mesmo quando é solicitada }\end{array}$ \\
\hline & $\begin{array}{l}\text { Integração do seu educando na comunidade escolar } \\
\text { Opinião sobre a relação educando/colegas/professora } \\
\text { Atenção e apoio dispensados ao educando } \\
\text { Medidas que poderiam ser postas em prática para uma melhor integração }\end{array}$ \\
\hline & $\begin{array}{l}\text { Diferenças e semelhanças entre o ensino/escola do país de origem e o } \\
\text { ensino/escola em Portugal } \\
\text { Diferenças } \\
\text { Semelhanças }\end{array}$ \\
\hline
\end{tabular}

5. ${ }^{\text {a }}$ etapa - análise e interpretação dos resultados obtidos.

Análise das entrevistas a partir dos quadros de análise e interpretação do discurso a partir das regularidades de opiniões, atitudes e acontecimentos significativos, e elaboração de um texto interpretativo dos resultados obtidos. É este processo de interpretação que iremos apresentar na parte III do nosso trabalho. 


\section{PARTE III - AS VOZES DOS ENTREVISTADOS \\ CAPÍTULO V - ANÁLISE E INTERPRETAÇÃO DOS RESULTADOS DA INVESTIGAC̣ÃO}

\section{NOTAS INTRODUTÓRIAS}

Neste capítulo, apresentamos a análise e interpretação dos dados recolhidos através das entrevistas que realizámos com o objectivo geral de contribuir para o conhecimento do papel do professor do $1 .{ }^{\circ}$ Ciclo do Ensino Básico na construção da cidadania em contexto intercultural. Assim, segue-se uma descrição qualitativa das principais conclusões obtidas através da análise de conteúdo, realizada aos três grupos de entrevistados. Esta análise e interpretação decorrem das categorias definidas por nós e será apresentada de acordo com a ordem dos blocos de cada guião das entrevistas realizadas.

Concordamos com Andy Hargreaves (1998:281) quando afirma que «na mudança educativa e na investigação em educação, a voz dos professores, não sendo anteriormente escutada ou valorizada, tem sido objecto de um respeito e de uma autoridade crescente nos anos mais recentes». Portanto, consideramos que para compreender a educação é necessário «escutar a voz do professor, a pessoa que ela exprime e os propósitos que articula». Neste trabalho tentaremos não só escutar essa voz, mas para além disso promovê-la, no âmbito do objecto em estudo. Como já referimos anteriormente, para além das vozes dos professores, escutámos igualmente as vozes dos seus alunos e das suas encarregadas de educação.

\section{ANÁLISE QUALITATIVA AO GRUPO DE PROFESSORES}

\section{BLOCO I - Apreciação da diversidade cultural presente na sala de aula}

\section{Categoria - Diversidade Cultural}

Como já referimos anteriormente, a escolha dos professores da amostra foi feita devido à presença nas suas turmas de crianças estrangeiras, filhas de imigrantes, brasileiros ou de países do Leste Europeu, a frequentar o 1.0 Ciclo do Ensino Básico (1. CEB) em Portugal. Assim, em cada uma das turmas dos professores entrevistados há um aluno ou aluna proveniente do Brasil ou de um país do Leste da Europa (Ucrânia, Bulgária, Moldávia e Rússia). Apenas em duas turmas se verifica a pre- 
sença de mais alunos estrangeiros. Uma dessas turmas tem três alunos brasileiros, dos quais só um entra no estudo e faz parte da amostra e a outra turma tem uma aluna brasileira, que faz parte da amostra, e duas crianças filhas de ex-emigrantes da Alemanha e Espanha que não estão incluídas na amostra por terem uma nacionalidade diferente das duas nacionalidades abrangidas por este estudo.

De uma maneira geral, os professores consideram que as turmas que leccionam são pouco heterogéneas em termos de diversidade sociocultural, salientando a presença das crianças estrangeiras, de uma criança de etnia cigana (presentes numa das turmas) e de uma criança cuja mãe é timorense como casos de excepção da homogeneidade da turma. Apenas dois dos professores entrevistados consideram que as suas turmas são heterogéneas devido aos vários níveis de aprendizagem dos alunos na sala de aula, a pertença dos seus alunos a famílias de diferentes níveis socioculturais e económicos e algumas situações de crianças com graves problemas socioeconómicos e sociais (filhos de pais toxicodependentes, de reclusos e de famílias separadas).

Relativamente à integração da criança estrangeira na sala de aula os professores expressam a sua opinião sobre condutas da criança em relação à turma, considerando que a maioria das crianças estrangeiras integraram-se e inseriram-se bem na turma, sem problemas de adaptação aos colegas e ao ensino de português, como é referido nas entrevistas:

- «(..) ela agora está perfeitamente integrada na turma sem qualquer tipo de problema» (P 1 B).

- «É uma criança que se integrou facilmente, fez amizades facilmente e não teve problemas de disciplina nem outro problema de qualquer origem» (P $2 \mathrm{~L})$.

- « (...) integram-se perfeitamente, brincam juntos, conversam, não há grandes diferenças, só noto que são crianças bastante mais agitadas (...).» (P 5 B).

- «A criança estrangeira da turma adaptou-se muito bem, é um aluno muito hiperactivo, é dos melhores alunos da turma (...) integrou-se bem na turma (...)» (P 8 L).

- «(..) acho que se integra perfeitamente» (P 9 B).

- «(..) ela é mais carinhosa, mais afável com as outras crianças, tem facilidade em contactar com elas e pronto, e fazem, ela gosta de se dar e de dar aos outros. é muito meiguinha». «Não, não [houve problemas de integração]» (P 10 L). 
São apontados alguns casos de crianças que revelaram algumas dificuldades iniciais na integração devido a falta de confiança em si próprias e insegurança, timidez e baixa auto estima, problemas comportamentais e a diferenças culturais.

Também expressaram a sua opinião sobre o comportamento dos alunos da turma em relação à criança estrangeira dizendo que os alunos da turma, de um modo geral, a aceitaram bem apesar de, inicialmente, se sentirem um pouco constrangidos, em alguns dos casos, mas curiosos em saber mais sobre as suas vivências. Uma das entrevistadas salienta:

- «Todos os alunos se dão bem, nunca apontaram o dedo, nunca a rejeitaram» (P $3 \mathrm{~L})$.

Apenas uma das entrevistadas revela que o seu aluno sentiu, inicialmente, alguma dificuldade de integração na turma porque:

- «(..) como falava com alguma facilidade, intervinha por tudo e por nada, dava a opinião e não era muito bem aceite pelos colegas $(. ..) \gg(P 4$ B).

Sobre o rendimento escolar dos alunos estrangeiros, os professores entrevistados referem que os seus alunos não têm tido dificuldade na aprendizagem, atingindo um médio ou bom aproveitamento, mesmo no caso dos alunos oriundos de países do Leste Europeu que se iniciaram há pouco na Língua Portuguesa. A confirmar este parecer apresentamos as suas opiniões:

- «[0 rendimento escolar] é óptimo».«(...) tem muito bom aproveitamento» (P $2 \mathrm{~L}$ ).

- «(..) é uma menina que está muito bem preparada».«(...) ela é uma das melhores alunas que tenho». «(...) exprime-se muito bem no português (...)» (P 3 L).

- «(..) tem um bom aproveitamento (...)» (P 6L).

- «Tem um rendimento escolar muito bom».«Em todas as áreas» (P 8 L).

- «(...) é um rendimento médio».«(...) a nível da Língua Portuguesa ela até está melhor que em Matemática» (...) (P 10L).

No caso dos alunos brasileiros, alguns professores inquiridos mencionam que os alunos revelam alguma dificuldade na Língua Portuguesa, 
principalmente na expressão escrita, como podemos observar nas suas opiniões:

- «(..) ainda tem como entrave a Língua Portuguesa, porque ainda escreve um bocado como fala $(. .). » . \ll(\ldots)$ tem vocabulário ainda muito infantil» (P $1 \mathrm{~B})$.

- «(..) agora já faz uma leitura mais razoável».«Tem alguma dificuldade em fazer uma redacção num português correcto» (P 4 B).

No entanto, uma das entrevistadas revela opinião contrária:

- «Ela não [tem dificuldade a nível da escrita] porque começou a aprender desde o início». «(..) não dá erros, a miúda». (P 9'B).

Perante a diversidade cultural, a postura do professor é diferente nos vários professores entrevistados. Um grande grupo de professores encara a diversidade cultural como uma mais-valia para o trabalho da sala de aula, aceitam o aluno «naquilo que ele é», não sentem grande dificuldade na prática pedagógica, apesar de se aperceberem de algumas diferenças culturais. Os que consideram que é uma mais-valia e ajuda para o trabalho na sala de aula justificam essa opinião dizendo que é enriquecedor a nível de aprendizagem de novo vocabulário, a nível do desenvolvimento da oralidade e possibilita a partilha de conhecimentos e a aquisição de novos saberes sobre países e culturas diferentes (língua, hábitos e costumes). Uma das entrevistadas sintetiza esta postura considerando:

- «É bom para todos, porque todos crescemos com a diferença, a diversidade também nos faz crescer (...)» (P 10 L).

Apenas uma professora entrevistada se posiciona numa perspectiva diferente, considerando que «não é uma mais-valia» para a prática pedagógica, servindo somente para mostrar como é a cultura do aluno estrangeiro, a nível das tradições, usos e costumes. Apesar desta postura, a entrevistada aceita igualmente o aluno como ele é, com as suas vivências, e tenta fazer com que o aluno exponha certos aspectos da sua cultura de origem, tal como salienta a entrevistada:

- « Há situações em que pergunto como é que ele fazia na Ucrânia (...) e ele conta histórias (...) da terra dele». (P 2 L).

Pensamos que esta última opinião se pode situar numa perspectiva de multiculturalismo benigno ou condescendente, onde o «outro»é, geral- 
mente, olhado de forma benevolente até com atitudes de tolerância passiva face à diferença.

Uma das inquiridas questiona-se, não só em relação à presença do aluno de origem estrangeira (cujo nível sociocultural é alto), mas sim, de uma forma mais geral, em relação à diversidade cultural presente na sua sala de aula, onde existe um grande grupo de crianças com um baixo nível sociocultural, colocando a questão da existência do currículo oculto do docente, quando nos diz:

- «Naturalmente que há e reajo também segundo o meu currículo oculto, não é? Aquilo que nós sabemos portanto, aquilo que culturalmente para mim aceite se calhar para eles não será assim tão bem aceite, tento quanto possível aceitar cada um naquilo que é, evito, e aceitar a diversidade cultural para mim passa por aí, evito fazer pouco ou dizer alto ou chamar a atenção alto de alguma situação menos correcta (...)» (...) aceito-os como eles são mas ao mesmo tempo sou exigente porque acho que o facto de viverem numa situação de menor grau cultural não quer dizer que não venham para a escola conhecer, saber mais (...)». (P 4 B).

Apesar da visão positiva face à diversidade cultural, considerando-a como uma mais-valia para a prática pedagógica, os professores não deixaram de exprimir algumas dificuldades sentidas perante a diversidade presente na sala de aula. Assim, é referida uma certa dificuldade na comunicação oral entre professores e alunos provenientes do leste da Europa a nível do significado das palavras, como relatam nas entrevistas:

- «Às vezes eu também tenho dificuldades em comunicar com ele (...) às vezes vejo-me um bocado aflita para the transmitir os conhecimentos» (P $2 \mathrm{~L})$.

- «(..) há certas coisas que é preciso explicar para ela perceber o que é que isso quer dizer em português (...) mas isso não é obstáculo(...)» (P 2 L).

No entanto, uma das professoras de alunos brasileiros (tem três alunos brasileiros na sua turmal refere essa dificuldade na comunicação:

- «(..) eles às vezes não percebem determinados vocábulos nossos e nós os deles (...)» (P 5 B).

A comunicação escrita também é referida como dificuldade, até mais no caso do aluno brasileiro pois este «escreve como fala» o que constitui um obstáculo para a correcta escrita em português. 
Outro tipo de dificuldade diz respeito a características do próprio aluno que tornam a partilha de vivências e de conhecimentos um pouco difícil, apesar das solicitações dos seus professores:

- « (...) é um menino muito tímido (...) ele ainda não partilha muito aquilo que tem (...) (P 7 B).

- «(..) essa aluna não é muito receptiva a falar sobre os costumes dela, da cultura, do país, da língua (...)» (P 6 L).

$\mathrm{Na}$ análise realizada às afirmações dos professores acerca das dificuldades que sentem perante a diversidade cultural, surgem-nos as seguintes ideias expressas pelos entrevistados que também consideramos relevantes no âmbito deste estudo:

- «Porque não há uma mexida efectiva no currículo formal, também não considero que haja uma verdadeira intervenção dessas diferenças culturais no desenvolvimento do trabalho escolar» (P 4 B).

- «(..) as escolas ainda não estão preparadas devidamente para terem casos de alunos que nos apareçam com outras línguas» e que «não temos apoios nenhuns para estes casos» (P 8 L).

- «(...) a nível da Língua Portuguesa deveriam ter apoio (...)» (P $10 \mathrm{~L})$.

Relativamente à questão da língua como factor decisivo para o sucesso escolar do aluno com origem estrangeira, os professores entrevistados consideram que a língua não pode ser um impedimento ao sucesso escolar. No entanto, alguns professores de alunos brasileiros pensam que, apesar de aceitarem a forma de falar do aluno, pode ser vista como um entrave para o sucesso escolar na medida em que empregam vocabulário não utilizado no nosso português e na expressão escrita revelam dificuldade em escrever correctamente. É de salientar que duas das professoras de alunos brasileiros mencionam que não vêem a língua como um impedimento porque os seus alunos estão a iniciar no nosso país a sua aprendizagem e por isso consideram que não têm problemas a nível escrito, nomeadamente a nível da ortografia e construção de frases.

No caso dos professores de alunos de países de Leste, nenhum deles vê a língua como um impedimento pois consideram que os seus alunos se expressam bem a nível oral, que desde o início do ano lectivo tem havido um aperfeiçoamento na oralidade da Língua Portuguesa e «isso vai reflectir-se na comunicação escrita» (P 6 L). Apenas duas professoras 
apontam como entrave o desconhecimento do significado de algumas palavras portuguesas e uma delas expressa a sua preocupação acerca da aprendizagem do português correcto pelo aluno estrangeiro, como podemos comprovar na seguinte opinião:

- «0 maior impedimento que eu vejo é ela não aprender a falar bem o português porque se estiver em casa com a mãe fala russo (...) se anda na rua vai buscar o vocabulário que é menos apreciado, é o calão (...)» (P $10 \mathrm{~L})$.

Uma professora afirma ainda:

- «A língua não pode ser um factor decisivo porque a língua tem que ser flexível, a língua tem que ser algo que se adapte à circunstância (...) »não implicando uma 'menor aprendizagem' (P 4 B).

\section{BLOCO II - Educação intercultural}

\section{Categoria - Opinião dos professores sobre a educação intercultural}

Na opinião expressa pelos entrevistados ao procurar uma definição de educacão intercultural percepcionamos diferentes níveis de envolvimento de professores e alunos no trabalho escolar. Encontrámos uma opinião que se situa num nível de conhecimento de culturas diferentes:

- «(..) dar conhecimento às crianças de que existem outras culturas, outras maneiras de $\operatorname{ser}(\ldots) \gg(P 2 \mathrm{~L})$.

Outras opiniões sugerem, para além de dar a conhecer a cultura diferente, uma partilha de conhecimento, de valores e costumes entre diferentes culturas:

- «É uma partilha de costumes de saberes (...)» (P 7 B).

- «(..) é uma educação entre culturas. É trazer coisas de uma outra cultura para a nossa e levar da nossa para a outra cultura diferente» (P 3 L).

- «(...) estes alunos estrangeiros começam a diferenciar os hábitos e costumes da sua terra natal para cá, para Portugal, e aí e os nossos meninos também aprendem com esses alunos» (P $8 \mathrm{~L}$ ).

- «(..) penso que seja uma educação (...) que esteja inserida nas várias culturas diferentes e haja um intercâmbio, uma coorde- 
nação entre essas culturas de modo a que se promova a educação na mesma, mesmo estando com essa diversidade de culturas» (P 5 B).

- «(..) se eu tenho alunos de diferentes nacionalidades, a educação a ser transmitida, a meu ver, tem que ser igual para todos de forma a que os costumes, as tradições de uns e outros sejam conjugados (...)» (P 1 B).

Outras opiniões destacam a necessidade de aceitar e respeitar as diferenças entre as diversas culturas, incentivando a reflexão sobre a diversidade:

- «É, no fundo, aceitarmos as diferentes culturas, não impormos a nossa (...)» (P 4 B).

- «(..) deve-se pôr em comum exactamente essa diferença e fazer com que seja (...) encarada como natural» (P 5 B).

- «(..) será tentar abordar os temas de uma maneira mais alargada», discutir os assuntos na sala de forma variada pois não há «só uma forma de ver os assuntos, tem que haver várias opiniões e vários pontos de vista (...) sem fazer qualquer tipo de crítica a nenhuma delas [às diferentes culturas] aceitando todas com os seus pontos comuns ou pontos contrários» ( $\mathrm{P} 6 \mathrm{~L}$ ).

Outras definições salientam a importância da educação intercultural para proporcionar melhor acolhimento e integração dos alunos de origem estrangeira:

- «É tentar inserir esses alunos na nossa cultura, também dando a conhecer a cultura dessas crianças aos nossos, de forma a integrar esse aluno ou esses alunos nos grupos» (P 1 B).

- «(..) penso que realmente ter várias culturas na sala, às vezes ajuda a integrar, eles apercebem-se que não somos todos iguais, e que neste país vive-se assim, no outro vive-se de outra maneira (...)» (P 9 B).

Um outro parecer destaca a importância da educação intercultural na promoção da cidadania, ao ponderar:

- «A educação intercultural será a educação em que a cultura faça parte integrante de toda a educação (...). Uma cultura diferente, mas que vai proporcionar uma educação para a cidadania mais responsável» (P 10 L). 
Esta opinião, em nosso entender, vai de encontro à ideia que a educação intercultural pode ajudar os jovens cidadãos a crescer na solidariedade, na interdependência, na mediação e na tolerância activa.

Quanto às formas de colocar em prática a educação intercultural, a maior parte dos professores refere o recurso ao diálogo, interpelando a criança para falar do seu país de origem com os colegas, referindo também a formação de «uma mesa redonda» de modo a permitir o conhecimento e a convivência com a diferença, a partilha de conhecimentos e de vivências. As opiniões expressas salientam que deve haver conhecimento entre as culturas presentes na sala de aula de forma a promover o bom relacionamento entre todos os alunos.

Outros referem que também pode ser colocada em prática através do programa nacional para o $1 .{ }^{\circ} \mathrm{CEB}$, especialmente através do Estudo do Meio, aproveitando datas festivas ou dias comemorativos para perguntar ao aluno como seria festejada ou comemorada essa data na sua terra natal. Consideram que, deste modo, o aluno pode expressar-se, trazer um pouco da sua cultura para a escola e sentir que esta é valorizada. Outros professores, para além do Estudo do Meio, mencionam as Áreas de Expressão, nomeadamente a expressão dramática, a música e a dança, para se colocar em prática a educação intercultural. Consideramos que estas práticas podem proporcionar uma abordagem dos conteúdos educativos na perspectiva de transmitir a variedade de herança cultural em si presente e podem dar origem a múltiplas actividades, como por exemplo, actividades de pesquisa sobre o país de origem dos alunos, como sugeriu uma das professoras.

Duas das opiniões destacam-se pois têm uma percepção um pouco negativa sobre a prática da educação intercultural. Uma delas considera:

- «As nossas escolas ainda não estão preparadas devidamente para terem casos de alunos com outras línguas (...).» Eu acho que aí havia de ter uma escola, do género ATL, para esses alunos. Era, portanto, a nível da Póvoa, há uns 4 ou 5 russos nas escolas da periferia da Póvoa e havia de haver um professor ou até sei lá, um pai, porque não propor que um pai russo desse a aula, pelos menos os primeiros passos». (P 8 L).

Uma outra opinião também revela que é muito difícil colocar em prática a educação cultural nas nossas escolas:

- «É muito difícil. Penso que teria que partir, (...) eu não estou a querer discriminar, atenção, ao dizer isto, mas estou a pensar nisso como uma mais valia para a turma, para o desenvolvi- 
mento de um trabalho, portanto, concentrar os alunos de uma escola, tentar a envolvência dos pais, procurar encontrar junto dos pais aquele que se disponibilizasse para servir de interlocutor entre o professor e os miúdos (...)». «Talvez concentrar os alunos das diferentes escolas aqui desta área numa escola que justificasse uma intervenção profunda em termos de educação intercultural, numa tentativa de intervir com estruturas que colaborassem no desenvolvimento da actividade escolar». «A partir do conhecimento que temos e com a colaboração de alguém ligado à cultura deles tentarmos criar uma ponte e desenvolver um trabalho que teria que caminhar a par da nossa cultura» (P 4 B).

Esta última afirmação parece-nos ser defensora de um bilinguismo cultural, o qual pode ser considerado como estratégia de sobrevivência, mas também como estratégia de acesso ao usufruto activo e pleno da cidadania numa sociedade multicultural. Esta professora considera ainda que não há prática nas escolas de uma educação intercultural mas sim a prática de uma educação que é a nossa, conhece algumas realidades escolares que acabaram por ficar pelo folclore, mas:

- «(..) esse folclore tornou-os mais felizes e o querer estar na escola já é muito importante para nós» (P 4 B).

Esta opinião, remete-nos para uma realidade escolar que evidencia a confraternização com alguns costumes e valores de outras culturas diferentes, geralmente numa perspectiva da sua folclorização.

A prática da educação intercultural é identificada pelos professores como sendo uma contribuição para o sucesso escolar dos alunos com culturas diferentes. Apresentam diversas razões para considerarem que a educação intercultural contribui para o sucesso escolar dos seus alunos de origem estrangeira, as quais mostramos em seguida. Alguns professores pensam que a prática da educação intercultural proporciona o «intercâmbio de vivências e de conhecimentos» e enriquecimento de todos os alunos da sala a nível cultural, o que, de acordo com as suas opiniões, vai beneficiar a aprendizagem e contribuir para uma formação bem sucedida do aluno. Outros consideram que, através da prática da educação intercultural, os alunos de culturas diferentes se sentem valorizados, não se sentem discriminados na turma e, deste modo, vão conseguir expor, sem medo, as suas opiniões, o que também contribui para o sucesso escolar. O ambiente estável da sala de aula, onde o aluno se sinta bem tratado, respeitado e bem acolhido que a prática da educação intercultural pode 
proporcionar é considerado, por alguns professores, como um factor importante para o sucesso escolar do aluno estrangeiro. É ainda referido pelos entrevistados que o contacto com diferentes culturas pode motivar a inter ajuda entre os alunos e conduzir a uma maior facilidade na aprendizagem escolar.

\section{Categoria: Conhecimento de orientações/directrizes do Ministério da Educação para a educação intercultural}

De uma maneira geral, os docentes revelam ter pouco conhecimento de orientações/directrizes do Ministério da Educação para a educação intercultural. Os que têm conhecimento referem que conhecem algumas das orientações/ directrizes salientando a vertente da integração, que a educação intercultural deve ajudar os alunos a ultrapassar as dificuldades sentidas na sua integração, realçando também que para que isso aconteça a nível de legislação está previsto o apoio na aprendizagem da Língua Portuguesa como segunda língua aos alunos cuja língua materna não seja o português (Artigo $8 .^{\circ}$ do Decreto-Lei 6/2001: «As escolas devem proporcionar actividades curriculares específicas para a aprendizagem da língua portuguesa como segunda língua aos alunos cuja língua materna não seja o português»). Destacam ainda outras orientações que conhecem, como por exemplo, que se deve aceitar a realidade social do aluno, a sua forma de estar e que é necessário conhecer bem as culturas de origem. No entanto, uma das entrevistadas declara que essas directrizes não saem do contexto legislativo e que nas escolas era necessário mais apoio, quer a nível da língua portuguesa, quer a nível de equipamento, quer a nível da criação de equipas de apoio lenvolvendo vários Ministérios em consonância, nomeadamente o da Segurança Social, da Educação e da Saúdel que prestassem um apoio válido.

\section{Categoria: Responsabilidade da escola na integração da criança estrangeira}

Quanto à responsabilidade da escola na integração da criança estrangeira, grande parte dos professores considera que a escola tem muita responsabilidade e justificam essa opinião dizendo que a escola tem uma grande responsabilidade na integração dessas crianças, pois ela «deve fazer tudo o que for possível para ajudar a criança a integrar-se o melhor possível», deve ser sensível a estes casos, de modo a «quando há actividades tentar pensar nesses miúdos em primeiro lugar» e é nela que a criança vai construir amizades, conviver e alicerçar as bases para cons- 
truir a sua vida no futuro. Apontam várias possibilidades de ajuda, entre elas a ajuda de carácter monetário, a frequência da cantina e ATL gratuitamente, pois «em vez de o menino ir para casa, metê-lo no ATL, onde vai conviver com meninos portugueses o que ajuda a desenvolver a linguagem».

Realçam ainda que a escola, como principal instituição que confere educação às crianças, depois da família, tem a responsabilidade de promover o ensino intercultural, de modo a orientar todos os alunos para a aceitação e convivência com a diferença cultural dos alunos estrangeiros, até «porque em casa os pais podem não ter esse espírito aberto». Duas das opiniões consideram que mais do que a instituição escolar é o professor que tem a maior responsabilidade na integração do aluno, quer pela sua postura no sentido de aceitar a diferença dos alunos, quer na planificação de estratégias e actividades que promovam a integração.

Outros docentes são de opinião que a responsabilidade da escola na integração das crianças tem que ser igual para alunos portugueses e alunos estrangeiros, «não deve haver separação, independentemente da nacionalidade do aluno». Salientam ainda que a maior preocupação será a integração do aluno e dos seus encarregados de educação na comunidade escolar e que, apesar de a escola ter responsabilidades na integração da criança estrangeira, também compete aos seus pais interessarem-se pela aprendizagem e desenvolvimento dos filhos, conversar com os professores e membros dos órgãos de gestão da escola para juntos encontrarem o melhor caminho para a integração das crianças e exigir do estado português e da instituição escolar, a partir do momento em que o estado os aceita como cidadãos, uma resposta «ao anseio de aprendizagem» dos seus filhos.

Apenas nos parece que uma das entrevistadas considera que a escola tem pouca responsabilidade na integração da criança estrangeira e sugere-nos novamente a perspectiva da folclorização de costumes, ao considerar:

- «(..) a escola pouco pode fazer». «(...) a escola pode fazer o, mesmo que pode fazer o professor, em tempo de festas e outras coisas deixar que as crianças façam as festinhas delas, ponham, façam os números deles, que façam...mais nada (...)» (P 2 L). 


\section{BLOCO III - Envolvimento dos pais/encarregados de educação de alunos estrangeiros com a comunidade escolar}

\section{Categoria: Opinião dos professores sobre a relação pais/encarregados de educação e escola}

Relativamente à relação pais/professor, os docentes não declaram qualquer tipo de problema com os pais dos alunos estrangeiros, dizendo que a relação é boa, normal. Tal como no caso dos alunos portugueses, há pais que se interessam mais pela aprendizagem dos filhos e que comparecem mais vezes na escola do que outros e é a mãe que contacta mais com a escola.

A partir das opiniões dos professores, concluímos que alguns dos pais destes alunos tiveram a preocupação de informar a professora sobre a situação relativa ao aluno, mostrando-se também preocupados com a sua aprendizagem, como podemos observar nas seguintes afirmações:

- «(..) logo no início do ano veio falar comigo para me pôr a par de que era de nacionalidade estrangeira, se eu notasse algumas dificuldades para falar com ela para ver se se poderia arranjar alguma maneira para tentar minimizar essas dificuldades» (P 3 L);

- «a princípio houve preocupação dela [da mãe] de que a criança não conseguisse acompanhar o grande grupo onde estava inserido $(\ldots) \gg(P 4 B)$.

Apenas um professor lamentou o facto de ainda não conhecer os pais da sua aluna mas que compreendia que ainda não tivessem vindo à escola por motivos profissionais.

Quanto ao interesse e apoio nas actividades escolares revelado pelos pais, uma grande parte dos professores considera que os pais são interessados, comparecendo na escola sempre que consideram necessário e/ou sempre que são solicitados e nas reuniões periódicas que efectuam. Outros docentes manifestam o seu descontentamento relativamente ao interesse dos pais, dizendo:

- «(..) os pais raramente comparecem. (...) são pais ausentes, despreocupados com o mundo escolar» (P5B);

- «Não me parecem ainda muito interessados, até para um menino que (...) teve uma adaptação eu esperaria que viessem falar mais vezes comigo, que estivessem mais interessados», 
no entanto acrescenta «sempre que eu chamo (...) eles vêm» (P7 B).;

- «(..) foi um caso em que não vieram cá, nem o pai, nem a mãe» (P 6 L).

Os docentes pensam que os pais tentam acompanhar e apoiar os filhos nas actividades escolares, uns prestando mais ajuda em casa do que outros. Assim, as opiniões divergem, alguns professores dizem que os pais ajudam nos trabalhos de casa, outros dizem que os pais apenas orientam e verificam se o filho fez ou não os trabalhos e, por último, outros docentes dizem que os seus alunos não são acompanhados nos trabalhos de casa e que os realizam sozinhos.

Dada a diversidade de respostas, não podemos tirar uma conclusão, nem é nosso objectivo emitir qualquer tipo de juízo, mas tentaremos mais adiante no nosso trabalho cruzar estas opiniões recolhidas neste terceiro bloco com as respostas dadas pelas encarregadas de educação, para tentar apurar quais os motivos porque não acompanham e não prestam apoio aos filhos, e no caso de acompanharem e prestarem apoio em casa tentar saber quais as dificuldades que encontram nessa tarefa.

\section{BLOCO IV - Educação para a cidadania}

\section{Categoria: Concepção de cidadania}

Ao emitir a sua opinião relativamente à definição de cidadania, os professores associaram imediatamente esta palavra a cidadão e sociedade. Também encontramos, na nossa análise, outras palavras como direitos, deveres ou regras e valores. Surgiram, assim, diversas definições e expomos em seguida algumas delas:

- «É o papel que cada um de nós tem na sociedade em que estamos inseridos». -«Temos regras a cumprir, direitos também que nos são conferidos (...) de maneira a que todos os cidadãos consigam conjugar de acordo com essas regras, (...) viver em harmonia (...) de acordo com as regras que nos são implementadas pelo nosso governo (...) e também os direitos que nos são aplicados através da constituição» (P 1 B).

- «É ser capaz de estar com os outros, aceitá-los mas nunca deixando os meus valores como referência». «(...) como cidadã cabe-me o papel de saber dizer aquilo que considero que são 
valores essenciais: (...) liberdade, a liberdade de expressão, o saber preservar o ambiente (...) » (P 4 B).

- «Ser bom cidadão claro implica ter determinados valores e determinadas regras que sejam aceites pela sociedade» (P 5 B).

- «Eu acho que tem a ver com a forma como nós vivemos em sociedade, com o respeito pelos outros, os nossos direitos e obrigações perante a nossa sociedade e a forma como nós pomos em prática, não é só saber dizer mas também fazer, pôr em prática, quer no relacionamento com os colegas, quer em família ou em sociedade» (P 6 L).

- «Cidadão é um ser que vai ter de viver de acordo com (...) o valor da liberdade, valor da verdade, da bondade e ter comportamentos cívicos, que é um bom comportamento, é um comportamento de integração assente nesses valores» (P 7 B).

- «0 cidadão é a pessoa que vive na cidade, e nós para ter a cidadania (...) as pessoas também têm que ser educadas para isso» (P 8 L).

- «(...) a palavra cidadania lembra-me cidadão (...) estamos num país livre, (...) temos que ter os nosso direitos e temos os nossos deveres, e temos que respeitar os direitos de cada um e a sua individualidade (...)» (P 9 B).

- «(..) lembra-me a palavra cidadão (...)». «[o exercício da cidadania] penso que é o estar presente em todas as acções que a sociedade possa desenvolver com atitudes correctas (...) acho que seríamos bons cidadãos se nos preocuparmos também com o presente e com o futuro, apesar de podermos não o viver, (...). Acho que a vida, a sociedade seria melhor, diferente» (P $10 \mathrm{~L})$.

Os professores que entrevistámos expõem a sua preocupação pela formação do futuro cidadão responsável, autónomo, crítico, activo e solidário, indo de encontro aos princípios legislativos expressos no Decreto- Lei n. ${ }^{0}$ 6/2001, e referiram-se à educação para a cidadania com as seguintes expressões:

- «Educar uma criança para ser um futuro cidadão que tenha responsabilidade nesta sociedade». «Será o homem de amanhã, responsável, e que vai gerir este país (...)» (P 2 L).

- «Tentamos educar as crianças implementando regras essenciais de cidadania ou de civismo (...) ensinar os miúdos a saber 
estar em sociedade, a saber fazer parte da sociedade também (...) executando (...) várias tarefas, de maneira a que eles se apercebam como é que devem agir perante os outros, haver aquele respeito mútuo, o cumprimento das regras [e] (...) a serem livres-pensadores (...) (P 1 B).

- «(..) formar [as crianças] como cidadãos (...) incutir-lhes (...) os valores correctos que são necessários para que (...) sejam inseridos na sociedade que os envolve». "Orientar e conduzir estas crianças (...) no sentido de mais tarde serem cidadãos autónomos, serem cidadãos responsáveis, serem cidadãos com boas atitudes e com bons valores, que saibam interajudar-se $(\ldots) \gg(P 5 B)$.

- «(..) educar no sentido de a criança crescer com estes valores [liberdade, verdade, bondade, solidariedade], saber que existe o outro, saber que há liberdade, a liberdade dele, a liberdade do outro, saber que há justiça, o porquê da verdade (...)» (P 7 B).

- «É educar o aluno para amanhã ser alguém (...) para se saber integrar na sociedade (...) » (P 8 L).

- « (...) é ajudá-los a crescer em todos os aspectos». « (...) ajudar os miúdos a crescer como cidadãos, que se preocupem com a natureza, com o ambiente, com a maneira de saber estar (...)» (P 9 B).

- «(..) educar para a cidadania será educar para sermos cidadãos responsáveis para que no futuro a sociedade seja muito mais justa, mais fraterna entre todos, que seja uma sociedade diferente (...) que seja melhor que a que vivemos». « (...) será educá- los de forma a que eles consigam obter valores (...)» (P 10 L).

Como podemos observar, estas opiniões vão de encontro à ideia de que educar para a cidadania é formar para a vida em sociedade, contribuindo para a construção da identidade e para o desenvolvimento da consciência cívica dos alunos.

Outras duas opiniões destacam a educação para a cidadania na sua dimensão intercultural, como se pode observar nas seguintes afirmações:

- «Para mim a escola cidadã e a escola intercultural no fundo não estão muito distantes uma da outra, no fundo uma responde à outra». «(...) tem que acontecer quer em termos culturais que estão pouco claros mas estão mais definidos em termos de 
educação para a saúde, educação para a paz, educação para os valóres cidadãos (...) e [para] os valores patrimoniais» (P 4 B).

- «(..) dentro da formação cívica estava incluída, um dos parâmetros era a educação intercultural» (P 6 L).

De facto, esta dimensão intercultural é extremamente importante para o desenvolvimento nas crianças de atitudes de alteridade, de conhecimento e valorização da cultura de cada um, de cooperação e respeito mútuo, independentemente da origem de cada aluno e sobretudo preparar futuros cidadãos preocupados com a promoção da justiça social e a eliminação de todas as formas de exclusão.

\section{Categoria: Importância da educação para a cidadania}

Todos os docentes entrevistados são unânimes quanto ao papel da educação para a cidadania, considerando que esta tem um papel muito importante e fundamental para o enriquecimento global das crianças como pessoas, para o desenvolvimento global da personalidade e que o processo de socialização dos alunos implica o desenvolvimento de uma consciência cívica.

Os entrevistados apontam diversas razões para a grande importância que atribuem à prática da educação para a cidadania em contexto escolar. Apresentamos em seguida as principais dessas razões que foram retiradas das afirmações expressas nas entrevistas.

Alguns professores consideram que a educação para a cidadania é um complemento da educação dada pela família, pois como referem a educação para a cidadania começa e faz-se naturalmente antes e no exterior da escola, no meio familiar, cabendo ao professor e à instituição escolar a função de educar, combater as falhas ao nível da socialização e «incutir regras de convivência». Deste modo, os professores entrevistados argumentam que a educação para a cidadania ajuda o aluno na construção da sua personalidade, sendo necessário «conduzi-lo para os valores correctos», para ele adoptar «boas maneiras e boas atitudes», pois mais tarde vai repercutir-se na sociedade.

Em nossa opinião, esta última consideração encara a educação para a cidadania como um instrumento de regulação social, cuja função é, basicamente, adequar as pessoas ao sistema social actual. 
Um outro parecer salienta que a educação para a cidadania é fundamental na educação:

- «Educar as crianças a crescer como cidadãos responsáveis (...) e hoje em dia é mais importante do que nunca (...) não se podem descurar os valores» (P 9 B).

Outra das razões apontadas é que a educação para a cidadania tem peso na boa integração dos alunos na escola, promovendo mais igualdade entre os alunos e mais respeito uns pelos outros.

Por último, a educação para a cidadania é também encarada como um investimento para o futuro, é vista como a preparação para a vida em sociedade, tendo como objectivo final a «formação de uma sociedade mais justa e verdadeira». Pensamos que esta opinião se enquadra numa abordagem que encara a educação para a cidadania como um factor de transformação social.

As opiniões dos entrevistados revelam que a responsabilidade da escola/professor na educação para a cidadania é grande e que a escola e professor têm um papel importante a desempenhar na educação para a cidadania, como se pode observar nas seguintes afirmações:

- (...) há aprendizagens que considero (...) devem ser começadas aqui [na escola] a ser trabalhadas». «0 investimento agora é investirmos para o futuro». «(..) a sensibilização não acontece em nós em adultos, a sensibilização acontece nas nossas escolas, em crianças» (P 4 B) .

- «[a responsabilidade da escola] (...) é educar as crianças implementando (...) regras essenciais de cidadania ou de civismo (...), ensinar os miúdos a saber estar em sociedade, a saber fazer parte da sociedade (...)». «(...) educar jovens com valores (...)» (P 1 B).

- «A escola é fundamental». «Porque todos eles vão ser cidadãos e urge que se formem cidadãos autónomos, responsáveis e conscientes daquilo que fazem, de que estão a praticar o bem, de que estão a contribuir para uma sociedade saudável e o papel da escola é muito fundamental nisto» (P 5 B).

Esta entrevistada acrescenta ainda:

- «(..) o professor sempre teve a preocupação de formar o aluno nesse sentido, conduzi-lo para uma boa cidadania, para ser um bom cidadão» (P 5 B). 
Estas opiniões remetem-nos para a sensibilização das crianças para as questões da cidadania e para a apropriação e interiorização de conceitos relativos aos direitos, deveres e valores de cidadania, desde cedo e de uma forma experiencial, de modo a obter efeitos mais profundos e efectivos.

Outros professores exprimem a sua opinião relacionando o papel da família e o papel da escola na educação para a cidadania. Reflectem também a sua preocupação pelo papel pouco activo da família dizendo que a educação de casa só por si já não chega e que a escola proporciona a convivência do aluno com outras crianças de diversos níveis socioeconómicos e com diferentes culturas, facultando o contacto com distintas realidades sociais. As seguintes citações ilustram o parecer dos professores sobre o papel da escola e o papel da família na aquisição e no desenvolvimento de competências de cidadania, que por vezes pode ser um processo conflituoso entre as práticas aconselhadas pela escola e as práticas recomendadas pela família, e simultaneamente revelam a importância que atribuem ao papel da escola e do professor:

- «(..) é claro que são importantes [o papel da escola/professor]. Porque se não lhe dão [educação] em casa, a escola tem que ser responsável também por isso, porque nós também não ensinamos só cientificamente, mas também educamos, não é?» (P 2 L).

- «Eu acho que [o papel da escola/professor] é muito importante porque os alunos passam cada vez mais tempo na escola, têm cada vez menos tempo para estar com os pais e mesmo debatendo estes temas muitos alunos ignoram (...) porque não têm depois uma família estável onde consigam pôr em prática depois também não conseguem pôr em prática na sua vida futura» (P 6 L).

- «(..) é importante porque a escola se calhar é a primeira sociedade que eles vão, é a família e depois a escola, é a segunda, pronto, é a sociedade onde eles vão começar a viver, é aqui que eles vão aprender as regras que depois irão aplicar no trabalho, na vida, na vida futura» (P 7 B).

- «O papel da escola será educá-los para a cidadania, será educá-los de forma a que eles consigam obter valores (...), antigamente os nossos pais preocupavam-se em dar-nos valores, esses valores iam sendo cultivados em nós mas agora acho que não, acho que a sociedade não deixa momentos aos pais em que os pais consigam transmitir esses valores, porque a vida é sem- 
pre a correr (...) e acabam por se esquecer que estão ali futuros adultos da sociedade. E cabe ao professor esse papel porque (...) nós passamos mais tempo que os pais em contacto directo, mas em contrapartida também é pouco (...) e não conseguimos colmatar essa falta» (P $10 \mathrm{~L})$.

Todas estas opiniões em relação à responsabilidade e papel da escola e ao papel do professor na educação para a cidadania vão de encontro à ideia de que ser cidadão é um processo que se pode desenvolver através da educação e da cultura e portanto aprende-se a ser cidadão, daí que o aprender a ser cidadão pode ser ensinado nas nossas escolas, mediante uma acção educativa que contribua e promova o desenvolvimento de competências de cidadania. Podemos ainda concluir que a educação para a cidadania é intrínseca ao processo educativo, contribuindo de forma significativa para o desenvolvimento global da personalidade do aluno.

\section{Bloco V - Práticas pedagógicas no âmbito da educação para a cidadania}

\section{Categoria: Formas de colocar em prática a educação para a cidadania}

Quando questionados sobre as formas de colocar em prática a educação para a cidadania, os inquiridos evidenciam uma preferência pela via da formação transversal, ou seja, a educação para a cidadania concretiza-se através da disseminação dos seus objectivos pelas diferentes áreas dos planos curriculares, como nos indicam as seguintes afirmações:

- «(..) eu acho que está a ser cúmplice em todas as disciplinas $(\ldots) » . \ll(\ldots)$ está inserida em todas as disciplinas» (P 1 B).

- «(...) ela [educação para a cidadania] aparece num sentido transversal, a abranger todas as áreas (...)» (P 4 B).

- «De certa forma, todas as áreas abrangem a educação para a cidadania (...)» (P 5 B).

- «Eu acho que o melhor caminho é não haver separação entre a disciplina [educação para a cidadania] e as outras disciplinas curriculares porque ao longo das aulas (...) em várias partes do programa é debatida ou há necessidade de falar desses valores (...)». «(...) deve haver mais interdisciplinaridade, deve estar inserida em todas as áreas» (P 6 L).

- «Num 1. ${ }^{\circ}$ ano (...) acaba por ser integrada nas áreas curriculares, aproveitando os temas (...) que falam muito da escola, da 
vida em sociedade [e de] valores (...) ».«Trabalho dentro das áreas curriculares (...) » (P 7 B).

- «Eu acho que é com o contributo de todas as áreas (...)». «Eu acho que está interligado» (P 8 L).

- «É um bocado integrado em todas as áreas [Matemática, Português, Estudo do Meio] (...)» (P 9 B).

- «(..) podemos dar a par mesmo das várias áreas, não é? Os conteúdos programáticos, mas também podemos ir buscar o resto, que vai complementar todas essas variantes que estão na formação cívica, que no fundo está lá tudo» (P 10 L).

- «(...) à medida que nós vamos preparando as aulas a educação para a cidadania está sempre presente porque nós estamos sempre a pensar» e se pusermos aqui este caso para eles perceberem melhor», este exemplo do dia-a-dia para eles não estarem a aprender no abstracto, estarem a aprender com coisas concretas que eles assim aprendem muito melhor» (P $3 \mathrm{~L})$.

Observámos através da leitura das entrevistas que os professores também colocavam em prática a educação para a cidadania quando decidiam aproveitar o momento em que surgia uma situação concreta, que eles consideravam oportuna, quando nos dizem:

- «(...) pode surgir uma situação em que temos que (...) pôr à prova a cidadania, o civismo das crianças (...) executando vários exercícios, várias tarefas, de maneira a que eles se apercebam como é que devem agir perante os outros, haver aquele respeito mútuo, o cumprimento das regras». «(..) pequenas situações do dia-a-dia que as próprias crianças promovem na sala de aula, o que faz com que eu chame a atenção para o civismo para a cidadania (...)» (P 1 B).

- «(..) nós, professores do $1 .{ }^{\circ}$ ciclo, que estamos sempre a educar a criança (...) não é preciso uma disciplina para a educação para a cidadania, que eu acho que ao chamar, estar a chamar a atenção ao miúdo... obrigá-lo a pedir desculpa, pedir por favor (...), acho que nós não precisamos de uma hora para dar essa área». «(...) uma pessoa se quiser, em qualquer altura está a dar» (P 2 L).

- «(..) qualquer momento nesta sala é um momento para trabalhar a cidadania, não deixo passar qualquer situação em que note que estão a fazer pouco uns dos outros ou que brigaram ou que não emprestaram uma caneta ou um lápis (...)» (P 4 B). 
- «(..) deve ser aproveitado o momento em que surge a situação. »Deve-se aproveitar a situação, porque às vezes (...) surge uma situação de conflito, deve-se aproveitar exactamente esse momento para abordar este tema [educação para a cidadania], como dar soluções, toda a turma entrar em união (...) para solucionar aquela situação, (...) estabelecer regras entre todos, entre o grande grupo da turma, regras que sejam eles a ditá-las e a respeitá-las». «(..) eu penso que deve ser abordada diariamente se for o caso, quando a situação surge» (P 5 B).

- «(..) ao longo das aulas (...) há necessidade de falar nesses valores (...) no comportamento dos alunos da sala de aula, na inter ajuda ou numa atitude menos própria de um aluno para outro colega, em várias situações» (P 6 L).

- «(..) eu acho que a professora primária está a dar sempre a toda a hora, é quase como o estudo acompanhado, e para a cidadania é igual (...)» (P 8 L).

- «Agora, a propósito de regras, do comportamento no intervalo, há determinadas coisas que fazem a gente ir buscar e falar-lhes acerca dessas coisas» (P 9 B).

- «(..) tem que se ir buscar nas pequenas coisas que por vezes acontecem na sala de aula (...)» (P $10 \mathrm{~L})$.

Outros professores revelam maior preferência pelo desenvolvimento de um projecto de natureza interdisciplinar, ao expressar:

- «(..) nós temos o projecto, área de projecto (...), aquilo que eu optei foi (...) cada grupo trabalha de forma transversal uma dessas situações da educação para a paz, educação para a saúde, a educação ambiental e a educação alimentar» (P 4 B).

- «Eu gosto do desenvolvimento a nível de um projecto. Eu acho que realmente a pessoa pode trabalhar esses valores mais ligada a um projecto mas isso depende da faixa etária. Num primeiro ano não é viável e acaba por ser integrada nas áreas curriculares (...)» (P 7 B).

- «Área de projecto. Trabalhámos nessa área» (P 8 L).

- «Eu acho que a melhor prática é o desenvolvimento da área de projecto» (P $10 \mathrm{~L})$. 
Outras opiniões dos inquiridos referem que utilizam datas ou dias comemorativos para colocar em prática a educação para a cidadania:

- «(..) até mesmo estes dias importantes, (...) talvez a gente marque talvez com algumas tarefas direccionadas para a formação cívica» (P 1 B).

- «(..) há aquelas datas específicas em que há sempre oportunidade para falar nisso» (P 7 B).

- «(..) devo fazê-lo pela oportunidade de datas a comemorar...» (P 4 B).

São relativamente poucos os professores, apenas duas das professoras entrevistadas, que escolhem a via do espaço curricular próprio, denominado como área de formação cívica, uma área curricular não disciplinar, com o apoio de um tempo semanal para sessões de informação e de debate que pose assumir o formato de assembleia de turma.

Uma das professoras entrevistadas, em relação à existência desta nova área curricular, ressalta:

- «(..) se tiver uma área específica para se poder abordar [a educação para a cidadania] seria muito melhor, mas aqui no 1. ${ }^{\circ}$ ciclo como nós fazemos a interdisciplinaridade (...) a educação para a cidadania está sempre presente». «Mas claro que se tivesse uma disciplina só a focar este aspecto claro que seria muito melhor porque aí iria basear-se só nisso» (P 3 L).

No entanto, esta docente argumenta que como o programa é extenso é necessário utilizar todo o tempo lectivo para o cumprir e por vezes falta tempo para esta nova área curricular não disciplinar.

Outra das inquiridas opta por esta via do espaço curricular próprio e afirma:

- «Aplico-a sempre... porque somos cidadãos sempre... em todos os momentos, umas vezes de forma mais específica porque criámos um espaço próprio (...) » (P 4 B).

Uma outra professora afirma que realiza assembleias de turma para discussão de problemas da turma, onde os alunos expõem situações de conflito que ocorrem na sala de aula, que depois são postos em discussão na turma. A professora acrescenta que através desta prática se podem «limar pequenas arestas, o que não se deve fazer e o que é que se deve fazer». 
Consideramos que é através da prática da democracia e da responsabilidade, vivenciada nas assembleias de turma, que se cria um espaço de diálogo e de reflexão sobre as experiências vividas pelos alunos e também sobre as questões relacionadas com a participação activa dos alunos na vida da turma e até da escola, quer a nível individual quer a nível colectivo.

Parece-nos, pelas leituras das opiniões, que os professores se preocupam com o desenvolvimento e amadurecimento nos alunos de uma consciência cívica e com o fortalecimento de uma atitude activa de desenvolvimento de competências contextualizada em situações de contacto (na família, na escola, no grupo de amigos), contribuindo, deste modo, para uma efectiva promoção da qualidade de vida cívica dos alunos. Algumas destas opiniões apresentadas (nomeadamente as que foram emitidas pelos entrevistados P1B, P3L, P4B, P6L, e P10L), alertam-nos para o facto de que o desenvolvimento de uma consciência cívica e a aquisição de determinados valores cívicos não devem ser promovidos através da apresentação de conceitos abstractos, pois apenas se aprende a ser cidadão através da vivência de situações práticas ao nível do exercício da responsabilização e da realização de actividades que ajudem a desenvolver competências cívicas. Assim, é essencial que os alunos contactem com situações reais do mundo em que vivem. Esses contactos podem revelar-se experiências significativas e fornecer elementos relevantes para a construção de uma identidade cívica assente na forma como as pessoas vivem a sua vida em comum e na sociedade e não em pressupostos de origem estereotipada.

Após esta análise realizada às opiniões expressas nesta categoria, concluímos que, apesar dos entrevistados terem evidenciado a sua preferência por um dos modos de colocar em prática a educação para a cidadania, isso não o impede de empregar, no seu trabalho pedagógico, outros modos de a colocar em prática. De facto, são vários os professores, oito no total, que desenvolvem com os seus alunos a educação para a cidadania conjugando algumas das formas referidas anteriormente.

\section{Categoria: Contributo dos currículos disciplinares}

Ao serem questionados sobre o contributo dos currículos das várias áreas disciplinares para a prática e desenvolvimento da educação para a cidadania, todos os professores entrevistados consideram que estes promovem e contribuem para a educação para a cidadania. 0 currículo da área de Estudo do Meio é o mais mencionado como sendo o que mais promove e o que mais contribui para a educação para a cidadania pois, segundo os 
professores, aborda regras de conduta, normas de higiene em geral e de higiene corporal, respeito pelos outros e inter ajuda, a vida em sociedade, a vida na escola, a família, as instituições e as regras de segurança. Outros currículos de outras áreas disciplinares são também mencionados, tais como, o currículo da área de Língua Portuguesa por abranger textos com temas e mensagens referentes a valores cívicos lligados à família, à liberdade) e da área da Matemática, o qual pode ajudar os alunos a ultrapassar determinadas dificuldades e contribuir para a resolução de dificuldades que surgem no dia-a-dia do aluno.

\section{Categoria: Temas mais importantes}

Dada a diversidade de temas enunciados pelos inquiridos tentámos agrupá-los em torno de um tema abrangente, mas todas as sugestões fornecidas foram tidas em conta para a elaboração desta listagem de temas que apresentamos em seguida:

a) O respeito e a valorização da diversidade cultural «respeito pelos outros», «reconhecer e respeitar a diferença e as culturas diferentes», «igualdade entre todos», «interajuda», «educação intercultural» e «saber respeitar a opinião dos outros».

b) O auto-conhecimento

«ter amor próprio», «conhecimento das regras básicas de higiene e limpeza», «autonomia e responsabilidade», saber ter a sua opinião», «saber ouvir» e «saber brincar».

c) Os direitos, os deveres e as responsabilidades sociais, os valores da cidadania

«educação para os valores», «regras sociais», «regras de boa educação», «saber estar e conviver com os outros», «ter conhecimento dos seus direitos e deveres na escola e na sociedade», «cumprimento dos deveres», «ser um bom cidadão», «liberdade», «justiça» e «educação para a paz».

d) O ambiente, a ecologia (física e humana), a saúde «educação para a saúde», «educação ambiental», «educação alimentar», «educação para os valores patrimoniais», «o meio envolvente (família, escola, sociedade)» e «prevenção rodoviária».

É importante salientar que o «respeito pelos outros» foi o tema referido mais vezes pelos docentes, seguido da «educação para os valores», de 
«ter conhecimento dos direitos e deveres» e de «saber estar e conviver com os outros».

\section{Categoria: Meios/recursos utilizados}

Relativamente aos meios e/ou recursos utilizados para colocar em prática a educação para a cidadania, os docentes referem variados meios e/ou recursos que em seguida expomos. Assim, muitos dos inquiridos informam que utilizam pequenas situações do dia-a-dia, notícias que os alunos trazem para a escola, notícias da comunicação social, exemplos da vida quotidiana e casos verídicos para desenvolver o trabalho pedagógico no âmbito da educação para a cidadania.

São também mencionadas algumas actividades realizadas na escola que podem proporcionar uma expressão das ideias e sentimentos de natureza cívica através de formas criativas, como por exemplo, actividades de educação física, de expressão plástica, de expressão dramática, de jogos didácticos e brincadeiras e actividades de organização da sala de aula e dos alunos da turma.

Outros professores referem que utilizam a exploração de manuais e livros, de documentos e textos, a leitura e exploração de histórias, o diálogo e debate, a invenção e relato de histórias utilizando slides, acetatos ou fantoches, a exploração de figuras, de desenhos, de fotografias, de postais, de cartazes, o desenho de esquemas no quadro e a utilização de meios audiovisuais.

São ainda referidas as visitas de estudo para a exploração de um determinado tema e a realização de entrevistas.

\section{Categoria: Conhecimento de orientações/directrizes do Ministério da Educação para a educação para a cidadania}

De um modo geral, os professores entrevistados revelam que têm conhecimento ou algum conhecimento das orientações/directrizes do Ministério da Educação para a educação para a cidadania expressas no Decreto-Lei n. ${ }^{\circ}$.6/2001. Portanto, têm conhecimento do aparecimento das três novas áreas curriculares não disciplinares, das quais destacam a formação cívica.

Alguns professores acrescentam que para além da informação que possuem por meio da legislação também se documentaram em jornais do 
campo educativo e em manuais editados pelo Ministério da Educação. Apenas dois dos docentes revelam o seu desconhecimento em relação às orientações/directrizes do Ministério da Educação para a educação para a cidadania.

\section{Categoria: Formação contínua}

Dado que as mudanças legislativas influenciam as praticas pedagógicas e podem até causar alguma instabilidade no trabalho docente quisemos saber se devido à introdução desta nova área curricular da formação cívica, ao carácter transversal da educação para a cidadania em todas as áreas curriculares e à vertente da educação para a cidadania como formação transdisciplinar havia necessidade de formação contínua nesta área.

Apesar de se sentirem preparados para trabalhar nesta área, uma vez que houve sempre a preocupação do professor do $1 .{ }^{\circ} \mathrm{CEB}$ pela formação global do aluno como pessoa, "porque o professor sempre teve a preocupação de formar o aluno nesse sentido, conduzi-lo para uma boa cidadania, para ser um bom cidadão" e pela sua plena integração na sociedade, os professores expressam as seguintes razões para a sua necessidade de formação contínua: actualização, obtenção de novos conhecimentos, orientação a nível de ideias - como trabalhar e explorar esta área, obtenção de materiais específicos, partilha de experiências, troca de conhecimentos entre professores, fugir à rotina do que é usualmente realizado.

A maioria dos professores admite que sente necessidade de formação no âmbito da educação para a cidadania, como se pode observar nas seguintes afirmações:

- «(..) é de toda a conveniência haver formação na educação para a cidadania». «(...) qualquer pessoa deve sentir necessidade de formação quanto mais não seja por uma questão de actualização» (P 4 B).

- «Penso que faria muita falta uma maior formação para esta área, porque foi assim uma mudança, implementaram estas novas três áreas não disciplinares mas (...) penso que não houve ao nível do corpo docente, uma verdadeira formação para aquilo que se pretendia com estas três novas áreas.» (...) era importantíssimo que fossem promovidas acções de formação, directrizes para que o professor se (...) pudesse orientar melhor, 
tivesse mais ideias de como trabalhar, como explorar estas áreas» (P5 B).

- «Acho que (...) necessitava de mais formação». «Mas sinto-me preparada, mas realmente também a necessitar de um bocadinho de mais formação» (P 7 B).

- «Se houvesse uma formação disponível para a cidadania, acho que, para nós era mais benéfico, porque nós andávamos com as outras, não é? E... aprendemos também umas com as outras, mas se houvesse uma preparação era muito mais útil, era mais rica, acho eu e aprendíamos mais» (P 8 L).

- «(..) a formação é sempre necessária e ajuda-nos sempre, até, a ter outras ideias, acho que sim». «Até porque a pessoa está sempre um bocado presa ao que costuma fazer (...) » (P 9 B).

Outras opiniões salientam que a planificação em conjunto com colegas nesta área também é uma boa ajuda porque permite a troca de ideias e que para colmatar a falta de formação pode ser feita pesquisa em livros de modo a obter o conhecimento que necessitam para melhor trabalhar com os seus alunos, como podemos constatar nas declarações que se seguem:

- «Penso que essa formação seria bem-vinda mas não me sinto menos incapaz por isso, porque acho que investigando alguns livros (...) consegue-se ter algum conhecimento do que pretende a educação para a cidadania. Depois nós como estamos sempre a conviver com miúdos que são muito irrequietos, (...) que não têm apoio moral em casa, claro que vai reflectir-se nos comportamentos deles na aula e então nós temos que tentar abordar os temas mais urgentes» (P 6 L).

- «(..) nós como fazemos sempre uma planificação em conjunto, às vezes a troca de ideias, o explorar em livros e tudo é óptimo para nós (...)». «Claro [se houvesse formação seria benéfico], porque o ensino é sempre estar em constante revolução, nunca é dizer que (...) sabemos tudo» (P $10 \mathrm{~L})$.

Apenas duas das professoras entrevistadas comentam que não sentem necessidade de formação contínua específica. Uma das docentes afirma que não necessita explicando:

- «(..) eu pessoalmente não necessito isso, porque eu sou católica, não é, e também acredito que uma criança sem valores não vai dar um grande adulto». «Desde que começamos a educar as 
crianças para a cidadania, para ser um jovem com valores decerto que não irá ser uma criança que entrará por maus caminhos (...). Acho que para a formação que eu já tenho a nível pessoal, acho que não necessito de mais, o necessário eu já sei e agora (...) tento transmitir aos alunos (...). Também por experiências, vivências pelas quais já passei e por conhecimento de vivências de outras pessoas que eu acho que são exemplo a apresentar perante os miúdos (...) há que educá-los, direccionando sempre para o lado correcto, não é, para o lado do verdadeiro cidadão, da verdadeira pessoa com valores» (P 1 B).

\section{BLOCO VI - Feedback dos alunos relativo à educação para a cidadania}

\section{Categoria: Importância das aprendizagens}

Todos os inquiridos reconhecem a grande importância das aprendizagens dos seus alunos no âmbito da educação para a cidadania. Os professores justificam a atribuição dessa importância relacionando-a com o desenvolvimento integral do aluno e a sua formação global como pessoa:

- «Acho que ajuda-os a crescer como pessoas (...)» (P 9 B).

- «Quando se abordam esses temas os miúdos ficam sensibiliza$\operatorname{dos}(\ldots) \gg($ P 5 B $)$.

- «(..) eles começam a crescer e têm que ver que há coisas que eles faziam mal e que estão a fazer bem, e que aprenderam muitas das vezes na escola» (P $8 \mathrm{~L}$ ).

- «(..) os miúdos acabam por tomar consciência que realmente procedem mal, eles têm consciência disso e reconhecem (...)» (P 1 B).

Outra opinião salienta também a importância das aprendizagens declarando:

- «(..) considero que são importantes, agora considero que eles conseguem saber quais são as regras mais importantes em termos de cidadania.» (...) eu espero que quando eles saírem daqui sejam capazes (...) de pensar antes de tomar uma atitude menos correcta, esse é o meu objectivo final» (P 4 B).

Em nosso parecer, esta opinião enquadra-se numa forma de abordagem da educação para a cidadania de dimensão mais pessoal, que visa desen- 
volver nos alunos competências de cidadania que thes permitam escolher, de forma autónoma, qual o caminho de participação e envolvimento social mais conveniente, de acordo com as respectivas preferências e motivações.

\section{Categoria: Impacto nos alunos}

Quando questionados sobre o impacto das aprendizagens realizadas no âmbito da educação para a cidadania nos alunos, os professores situam esse impacto a diferentes níveis.

A nível de mudança de atitudes/comportamentos, os professores concordam que as aprendizagens podem conduzir a alterações de atitudes/comportamentos dos alunos. Assim, os professores acrescentam que se pode observar resultados positivos a nível individual em pequenas «coisas», tais como, «não proceder mal», «cumprimento das regras da escola», «boa utilização das instalações escolares», mas também a nível colectivo ligado ao «relacionamento entre os alunos» e ao «comportamento na sala de aula e no recreio». A propósito da mudança de atitudes/comportamentos, um dos professores refere:

- «(...) reparei que se essa formação não acabasse, os alunos mudavam o seu comportamento progressivamente». «(...) porque é não sei, se é só para agradar ao professor, se é para fazer comparação entre o colega e o próprio aluno, porque ao verem os outros a fazer e sabem que não deveria ser feito assim, esses alunos tentam mudar o seu comportamento» (P 6 L).

Consideramos que estas opiniões se enquadram numa abordagem que perspectiva a educação para a cidadania como um instrumento de mudança individual do próprio aluno.

Esta mudança de atitudes a nível individual pode mais tarde implicar uma mudança da sociedade, como expõe uma das professoras:

- «(..) penso que todas as aprendizagens que os levam a formar bons cidadãos, tudo é óptimo, porque poderíamos ter uma sociedade daqui a vinte anos, muito melhor que a nossa de hoje» (P 10 L).

Todos os inquiridos realçam que têm vindo a verificar que há uma maior preocupação e envolvimento dos alunos com as questões da cidadania, 
pois ao desenvolverem o sentido da responsabilidade, empenham-se mais na vida colectiva da turma e também da escola, acabam por «chamar à atenção uns aos outros» para actuar correctamente em determinada situação, envolvem-se no debate em certas situações de conflito, sabendo exprimir a sua opinião e distinguir o certo do errado. Uma professora acrescenta ainda que os alunos se preocupam mais uns com os outros considerando que esse facto já é um primeiro passo para termos uma «sociedade mais amiga».

\section{Categoria: Índice da consciência cívica}

A maior parte dos professores afirma que os seus alunos vão interiorizando e consolidando, aos poucos e ao longo do 1. ${ }^{\circ} \mathrm{CEB}$, uma consciência de cidadania, situando-os a um nível médio/bom no que diz respeito a atitudes correctas, à distinção do certo e do errado, a medir atitudes para não prejudicar o outro, às regras mais importantes de cidadania e ao cumprimento das regras da escola. No entanto, alguns professores expressam a sua preocupação relativamente a certos aspectos que podem prejudicar a acção educativa da escola no sentido do desenvolvimento das competências de cidadania, como por exemplo, a questão das vivências a nível familiar, quando dizem nas entrevistas que realizámos:

- [alguns alunos] «não são chamados à atenção em casa» quando agem erradamente, «mas na escola são, sem dúvida alguma» $(\mathrm{P} 1 \mathrm{~B})$;

- «(..) fora do espaço escolar podem ter outro comportamento porque sabem que não são chamados à atenção, nem pelos pais, na maioria das vezes, não é, nem por outras pessoas que os rodeiam» (P 6 L).

Uma das professoras expressa ainda:

- «Apesar de considerar que os alunos conseguem saber quais são as regras mais importantes, «o problema está em se eles têm a consciência, se se consciencializaram já, se aquilo já está no seu inconsciente e se eles já trabalham em função dessas práticas de educação para a cidadania. Há situações obviamente que eles fazem, há outras situações que não» (P 4 B). 


\subsection{Síntese das ideias centrais do grupo de professores}

Os nossos entrevistados reconhecem que a maioria das crianças estrangeiras se integrou e se inseriu bem na turma, sem revelar problemas de adaptação ao meio escolar. Os casos pontuais que são indicados como denunciadores de certas dificuldades iniciais na integração são devidos, na opinião dos seus professores, a alguma insegurança, timidez e baixa auto estima, problemas comportamentais do próprio aluno e às diferenças culturais entre a cultura de origem e a cultura portuguesa. De um modo geral, os alunos da turma aceitaram e reagiram bem à presença da criança estrangeira, não a rejeitando. No entanto, inicialmente, sentiram- se um pouco constrangidos, em alguns casos, mas interessados em saber mais sobre as vivências dos alunos imigrados.

0 rendimento escolar dos alunos estrangeiros do nosso estudo é situado pelos seus professores a um nível médio/bom, comprovando as suas opiniões o sucesso escolar destes alunos. Referem que estes não têm tido dificuldade na aprendizagem, até no caso dos alunos vindos de países do leste europeu (Rússia, Bulgária, Ucrânia e Moldávia) e que iniciaram há pouco tempo a aprendizagem da língua portuguesa. No caso dos alunos oriundos do Brasil, alguns professores referem a sua dificuldade na língua portuguesa, especialmente na expressão escrita. De uma das opiniões transparece a ideia de que a aprendizagem da língua portuguesa no ensino português desde o início da escolaridade obrigatória $\left(1 .^{\circ}\right.$ ano de escolaridadel seria proveitosa para o percurso escolar do aluno estrangeiro em Portugal pois poderia evitar o erro ortográfico na expressão escrita.

A maioria dos professores considera a diversidade cultural como uma mais valia para o trabalho pedagógico. Justificam essa opinião alegando que é enriquecedor a nível de aquisição de vocabulário, a nível do desenvolvimento da oralidade, possibilitando ainda a partilha de conhecimentos e a obtenção de novos saberes sobre países e culturas diferentes da nossa. Somente uma entrevistada considera que «não é uma mais-valia» para a prática pedagógica, servindo unicamente para mostrar como é a cultura do aluno estrangeiro, a nível das tradições, usos e costumes.

A dificuldade na comunicação oral entre professores e alunos do leste europeu a nível do significado das palavras é apontada como uma dificuldade sentida perante a diversidade presente na sala de aula. No entanto, uma das professoras de alunos brasileiros refere também essa dificuldade na comunicação. A comunicação escrita é igualmente referida como uma dificuldade, principalmente no caso dos alunos brasileiros que geralmente escrevem como falam, na opinião dos seus professores. 
Outro género de dificuldades mencionado é relativo a características do próprio aluno que tornam a partilha de vivências e de conhecimentos um pouco difícil, apesar das solicitações dos seus professores. É ainda identificada como dificuldade a falta de preparação das escolas para atender casos de alunos estrangeiros, sobretudo a nível da existência de professores de apoio para ajudar estes alunos na aprendizagem da língua portuguesa. Por último, encontramos uma opinião que expressa que sem uma modificação no currículo formal não considera que possa existir uma efectiva intervenção das diferenças culturais no desenvolvimento do trabalho escolar.

Todos os professores entrevistados pensam que a língua não pode ser um impedimento ao sucesso escolar do aluno estrangeiro. No entanto, alguns dos professores consideram que a língua pode ser encarada como um obstáculo à expressão do aluno em português correcto e para a compreensão do significado de palavras. Os entrevistados expressam ainda a sua preocupação pelo facto de o aluno fora da escola não aprender a falar o português correcto.

Ao procurar definir o conceito de educação intercultural, os inquiridos expõem diversas opiniões. Assim, encontrámos uma opinião que define este conceito como um simples conhecimento de culturas diferentes. Outras opiniões sugerem, para além do conhecimento das culturas diferentes, uma partilha de conhecimento, de valores e costumes entre diferentes culturas. Alguns professores destacam ainda a função da educação intercultural na melhoria do acolhimento e da integração da criança estrangeira, salientando igualmente a importância desta educação na promoção da cidadania.

Para colocar em prática a educação intercultural, a maior parte dos professores recorrem ao diálogo, de modo a permitir o conhecimento e a convivência com a diferença, a partilha de conhecimentos e de vivências. Acrescentam ainda que este conhecimento das culturas presentes na sala de aula poderá ajudar a promover o bom relacionamento entre todos os alunos. Outros entrevistados referem que também pode ser colocada em prática através do programa nacional para o 1. ${ }^{\circ} \mathrm{CEB}$, especialmente através do Estudo do Meio e das Áreas de Expressão (designadamente a expressão dramática, música e dançal, de modo a facilitar a comunicação entre o aluno estrangeiro e os seus colegas portugueses e a valorização da sua cultura em meio escolar.

A prática da educação intercultural é identificada pelos professores como um contributo para o sucesso escolar dos alunos com diferentes cultu- 
ras. Das diversas razões apontadas para esta relação evidenciam-se as seguintes: a prática de uma educação intercultural facilita o intercâmbio de vivências e de conhecimentos, fomenta o enriquecimento dos alunos a nível cultural, contribui para a valorização e para a não discriminação do aluno estrangeiro, favorece a criação de um ambiente de sala de aula estável, acolhedor e respeitador, e, finalmente, o contacto com diferentes culturas motiva a inter ajuda entre todos os alunos e facilita a aprendizagem escolar.

A maioria dos docentes revela ter pouco conhecimento de orientações/directrizes do Ministério da Educação para a educação intercultural. Os que têm conhecimento realçam a vertente da integração, que a educação intercultural deve ajudar os alunos a ultrapassar as dificuldades sentidas na sua integração, ressaltando também que a nível de legislação está previsto o apoio na aprendizagem da Língua Portuguesa como segunda língua aos alunos cuja língua materna não seja o português. Destacam ainda outras orientações, tais como, que se deve aceitar a realidade social do aluno, a sua forma de estar e que é necessário conhecer bem a sua cultura de origem. Porém, uma das entrevistadas afirma que essas directrizes não saem do contexto legislativo e que nas escolas era necessário mais apoio la nível da língua portuguesa, a nível de equipamento, a nível da criação de equipas de apoio).

Grande parte dos professores considera que a instituição escolar tem muita responsabilidade na integração da criança estrangeira e justificam essa opinião referindo que a escola deve fazer tudo o que for possível para ajudar a criança a integrar-se na comunidade educativa e tem ainda a responsabilidade de promover o ensino intercultural, de modo a orientar todos os alunos para a aceitação, respeito e convivência com a diferença cultural. Duas das opiniões ponderam que mais do que a instituição escolar é o professor que tem a maior responsabilidade na integração do aluno, quer pela sua postura no sentido de aceitar a diferença dos alunos, quer na planificação e execução de estratégias e actividades que promovam a integração. Outros docentes são de opinião que a responsabilidade da escola na integração das crianças tem que ser igual para alunos portugueses e alunos estrangeiros, salientando que, neste processo, a maior preocupação será a integração do aluno e dos seus pais/encarregados de educação na comunidade escolar e sublinham também a responsabilidade dos pais/encarregados de educação na integração dos seus filhos/educandos, no sentido de se interessarem pela sua aprendizagem e pelo seu desenvolvimento e de comunicarem com a escola para que juntos encontrem o melhor caminho para a integração das crianças. 
Quanto à relação entre pais/encarregados de educação e professor, os docentes não mencionam qualquer tipo de problema com os pais/encarregados de educação dos alunos estrangeiros, dizendo que estabeleceram uma boa relação. A partir das opiniões dos professores, concluímos que alguns dos pais/encarregados de educação destes alunos tiveram a preocupação de informar a professora, logo no início do ano lectivo, sobre a situação do filho/educando, mostrando-se também preocupados com o desenvolvimento da sua aprendizagem. No que diz respeito ao interesse e apoio nas actividades escolares mostrado pelos pais, uma grande parte dos professores considera que os pais são interessados, comparecendo na escola sempre que consideram necessário e/ou sempre que são solicitados e nas reuniões periódicas que efectuam.

Os docentes entrevistados almejam a formação global das crianças como seres humanos e manifestam nos seus discursos, a necessidade da formação do futuro cidadão responsável, autónomo, crítico, activo e solidário, indo de encontro aos princípios legislativos expressos no Decreto- Lei n. ${ }^{\circ}$ 6/2001 para a educação para a cidadania, destacando também a sua dimensão intercultural. Assim, todos os entrevistados consideram que a educação para a cidadania tem um papel muito importante e fundamental para o enriquecimento global das crianças como pessoas, para o desenvolvimento global da personalidade e que o processo de socialização dos alunos implica o desenvolvimento de uma consciência cívica.

Os professores inquiridos indicam os motivos porque consideram importante a prática da educação para a cidadania, exprimindo que a educação para a cidadania é um complemento da educação dada pela família, ajuda - aluno na construção da sua personalidade, promove a igualdade e o respeito pelos outros, é um investimento para o futuro e uma preparação para a vida em sociedade.

As opiniões dos entrevistados revelam ainda que a responsabilidade da escola e do professor na educação para a cidadania é grande e que a escola e o professor têm um papel importante a desempenhar na educação para a cidadania, As suas opiniões remetem-nos para a necessidade de uma sensibilização das crianças para as questões da cidadania, desde o início da escolaridade, realizada através da vivência de situações práticas que ajudem a desenvolver competências cívicas, contactando com situações reais do mundo em que vivem. Alguns professores expressam ainda a sua preocupação pelo papel pouco activo da família nas questões de cidadania ponderando que, por vezes, pode existir um processo conflituoso entre as práticas aconselhadas pela escola e as práticas recomendadas pela família. 
Os inquiridos evidenciam preferência pela via da formação transversal, como uma forma de colocar em prática a educação para a cidadania, neste caso, a educação para a cidadania concretiza-se através da disseminação dos seus objectivos pelas diferentes áreas dos planos curriculares. Os professores também colocam em prática a educação para a cidadania quando decidem aproveitar o momento em que surge uma situação oportuna, quando optam pelo desenvolvimento de um projecto de natureza interdisciplinar no âmbito desta área ou ainda quando se servem de datas ou dias comemorativos para a colocar em prática. São poucos os professores que escolhem a via do espaço curricular próprio, designado por área de formação cívica, uma área curricular não disciplinar, com o apoio de um tempo semanal para sessões de informação e de debate que pode assumir o formato de assembleia de turma. Apesar dos docentes terem evidenciado a sua preferência por um dos modos de colocar em prática a educação para a cidadania, a maioria dos entrevistados utiliza, no seu trabalho pedagógico no âmbito da educação para a cidadania, uma conjugação de alguns desses modos referidos anteriormente.

Todos os professores entrevistados consideram que os currículos das várias áreas disciplinares promovem e contribuem para a educação para a cidadania. Apesar de ser indicado o currículo da área de Estudo do Meio como o que mais promove e o que mais contribui para a educação para a cidadania, outros currículos de outras áreas são também mencionados, tais como, o de Língua Portuguesa por abranger textos com temas e mensagens referentes a valores cívicos e o da Matemática que, na opinião dos docentes, pode auxiliar os alunos a ultrapassar determinadas dificuldades e pode contribuir para a resolução de dificuldades do dia-a-dia.

Os temas mais importantes a abordar no âmbito da educação para a cidadania sugeridos pelos professores entrevistados foram por nós agrupados em quatro grandes temas. Deste modo, consideramos que as sugestões fornecidas pelos entrevistados se agrupam em torno dos seguintes temas principais: o respeito e a valorização da diversidade cultural; o auto conhecimento; os direitos, os deveres e as responsabilidades sociais, os valores da cidadania; o ambiente, a ecologia (física e humana) e a saúde.

Os docentes referem diversos meios e/ou recursos utilizados para colocar em prática a educação para a cidadania recursos que em seguida enunciamos: recorrem a pequenas situações do dia-a-dia, notícias que os alunos relatam, notícias da comunicação social e exemplos da vida quotidiana. São também mencionadas algumas actividades que podem proporcionar uma expressão das ideias e sentimentos de natureza cívica através de formas criativas nas Áreas das Expressões, de jogos didácticos 
e brincadeiras e actividades de organização da sala de aula e dos alunos da turma. Utilizam ainda a exploração de manuais e livros, de documentos e textos, a leitura e exploração de histórias, o diálogo e debate, a invenção e relato de histórias empregando slides, acetatos ou fantoches, a exploração de fotografias, de postais, de cartazes e a utilização de meios audiovisuais. São ainda referidas as visitas de estudo para a exploração de um determinado tema e a realização de entrevistas.

De um modo geral, os professores entrevistados declaram que têm algum conhecimento das orientações/directrizes do Ministério da Educação para a educação para a cidadania expressas no Decreto- Lei n. ${ }^{0}$ 6/2001, tendo conhecimento do aparecimento das três novas áreas curriculares não disciplinares, das quais destacam a área de formação cívica. Para além da informação que possuem por meio da legislação alguns dos professores também procuram mais informação em jornais de âmbito educativo e em documentos publicados pelo Ministério da Educação. Apenas dois dos docentes revelam o seu desconhecimento em relação às orientações/directrizes do Ministério da Educação para a educação para a cidadania.

A maioria dos professores entrevistados admite que sente necessidade de formação no âmbito da educação para a cidadania para obtenção de novos conhecimentos, de materiais específicos e de ideias inovadoras sobre como trabalhar e explorar esta área, para se envolver na partilha de experiências e troca de conhecimentos entre professores e para fugir à rotina do trabalho pedagógico usualmente realizado. Algumas das opiniões recolhidas salientam que a planificação em conjunto com colegas permite a troca de ideias e que para colmatar a falta de formação se pode pesquisar em livros de modo a obter o conhecimento que necessitam para melhor trabalhar com os seus alunos. Apenas duas das professoras entrevistadas declaram que não sentem necessidade de formação contínua específica.

Todos os inquiridos reconhecem a grande importância das aprendizagens dos seus alunos no âmbito da educação para a cidadania. Os professores justificam a atribuição dessa importância relacionando-a com o desenvolvimento integral do aluno e a sua formação como pessoa e futuro cidadão.

Para os professores entrevistados, o impacto das aprendizagens realizadas no âmbito da educação para a cidadania nos alunos dizem respeito a mudança de atitudes e comportamentos, podendo observar-se resultados positivos a nível individual no bom comportamento, no cumprimento das regras da escola e na boa utilização das instalações escolares, 
e também a nível colectivo ligado ao bom relacionamento entre os alunos e ao comportamento na sala de aula e no recreio. De acordo com algumas das opiniões, esta mudança de atitudes a nível individual pode mais tarde implicar uma transformação da sociedade no sentido de a melhorar e de a tornar mais justa e mais humana.

Todos os inquiridos afirmam que têm vindo a verificar que há uma maior preocupação e envolvimento dos alunos com as questões da cidadania, pois ao desenvolverem o sentido da responsabilidade, empenham-se mais na vida colectiva da turma e também da escola. Declaram ainda que os seus alunos vão interiorizando aos poucos uma consciência de cidadania, situando-os a um nível médio/bom no que diz respeito a atitudes correctas, à distinção do certo e do errado, à sua capacidade para medir atitudes de modo a não prejudicar o outro, à interiorização das regras mais importantes de cidadania e ao cumprimento das regras da escola. No entanto, alguns professores expressam a sua preocupação relativamente a certos aspectos que podem prejudicar a acção educativa da escola no sentido do desenvolvimento das competências de cidadania, como por exemplo, a questão das vivências a nível familiar. Na verdade, de pouco vale que o aluno experimente e desenvolva competências de cidadania dentro da escola se, fora dela, a família, instituições e grupos do exterior contestarem essas competências e suscitarem modelos de comportamento contrários aos adquiridos no meio escolar. É, pois, necessário estabelecer uma partilha entre a escola, a família e as instituições da comunidade em relação à formação cívica das crianças, de modo a assumir a formação cívica como uma função colectiva.

\section{ANÁLISE QUALITATIVA AO GRUPO DE ALUNOS}

\section{BLOCO I - Actividades escolares}

\section{Categoria: Gosto pela frequência da escola}

Todos os alunos entrevistados afirmam que gostam de frequentar a escola e apontam as seguintes razões para gostar de «andar» na escola: desejo de aprender «coisas novas», os novos amigos e o facto de considerarem a escola «gira e boa». Apenas uma das alunas diz que gosta «mais ou menos» da escola devido à quantidade de trabalhos que leva para executar em casa. 


\section{Categoria: Actividades escolares que mais gosta de realizar}

Quando inquiridos sobre as actividades que mais gostam de realizar, os alunos de origem de leste destacam com maior frequência as actividades de matemática, em seguida o desenho, e por último as actividades de educação física e a leitura. No caso dos alunos brasileiros, não encontrámos uma resposta predominante e as actividades referidas são muito variadas: actividades de matemática, de língua portuguesa, de música, a pintura e o desenho, o estudo e as brincadeiras.

\section{Categoria: Actividades escolares que gostaria de realizar}

Relativamente às actividades que os alunos não realizam na escola mas que gostariam de realizar, alguns deles sugerem actividades, como por exemplo, brincar mais, fazer mais ginástica, fazer ginástica no pavilhão (com aparelhos, jogos de voleibol e basquete), fazer mais desenhos e ir à escola todos os dias.

Outros alunos não sugerem actividades:

- «Tudo que eu quero fazer na escola, eu faço» (A 1 B).

- «Eu gosto de tudo o que aqui faz, tudo» (A 2 B).

\section{Categoria: Acontecimentos escolares}

São indicados pelos alunos como bons acontecimentos as seguintes situações: brincar no recreio com os colegas, ter amigos, fazer jogos com a professora, escrever, fazer desenhos, fazer visitas de estudo, aprender e estudar, ajudar os colegas nos trabalhos, a «ciência divertida», as palestras e as actividades de educação física.

Quando questionados sobre os acontecimentos menos bons que acontecem na escola, os alunos referem a questão das relações interpessoais, de amizade, a qual, pela leitura das opiniões expressas, nos parece de extrema importância na sua vivência escolar:

- «Então, quando a professora grita, que os meus colegas não brinquem comigo, que não tenho nada para fazer, que ninguém quer saber de mim (...) » (A 2 L).

- «É não ter amigos, é brigar com os outros. De resto é tudo bom» (A 1B). 
- «Que eles comecem a xingar assim eu, a mim e não tenho mais nada» (A 2 B).

- «Que às vezes os meninos da outra sala ficam a criticar-me, da outra sala. Nesta ninguém fala isso comigo, só os meninos da outra sala» (A 3 B).

- «É que quando eu vou para o recreio tem muitas vezes que eles não brincam comigo» (A 4 B).

Referem também algumas actividades escolares que não gostam muito de realizar, tais como, trabalhos na área de estudo do meio, de gramática, trabalhos com a tesoura e actividades de educação física.

São ainda mencionadas por uma das alunas algumas perturbações do ambiente da sala de aula:

- «Quando os rapazes andam a correr pelas mesas, andam-se a bater e andam a atirar as tampas dos lixos (...), atirar caixas pelo ar, atirar os materiais pelo ar (...)» (A $1 \mathrm{~L})$.

\section{Categoria: Significado de aprender}

O significado de aprender não é igual para todos os alunos. Alguns dos alunos provenientes de países do leste europeu verbalizam opiniões que nós pensamos estar relacionadas com uma perspectiva de integração no nosso país:

- «Aprender é muito importante (...)». «Porque (...) quando nós viemos aqui para Portugal, não sabemos nada, então fomos para a escola, aprendemos a falar português, a fazer as coisas, a escrever, matemática também» (A 1 L).

- «Então, estudar, fazer os números, ler um bocadinho todos os dias e fazer os deveres, o que a professora manda». «É [importante aprender] porque depois quando crescemos temos que saber as coisas. Senão imagine vamos ao supermercado e não conseguimos ler o preço ou a palavra ou qualquer coisa e temos que perguntar a outras pessoas e aí é uma vergonha, não é?» (A 2 L).

- «Aprender quer dizer aprender coisas que o professor deu». «Porque aprender, assim aprende-se mais coisas e depois vai para algum lado e já sabe-se fazer essas coisas» (A 5 L). 
Outras opiniões demonstram a vontade de saber mais:

- «Estudar». «Para saber mais» (A 3 L).

- «É fazer números, fazer letras». «É [importante aprender]». «Porque a gente não sabe fazer números nem letras (...)» (A $4 \mathrm{~L})$.

- «Acho que é ser boa aluna, acho que tem que se respeitar as professoras...». - «É muito bom [aprender]» (A 1 B).

- «Para mim essa palavra é saber escrever e tudo isso e saber tudo, o alfabético e tudo» (A 2 B).

- «Saber. Significa saber mais» (A 3 B).

- «É bom, para mim é bom aprender». «[É] estudar» (A 4 B).

Uma última ideia tem em vista um trabalho futuro:

- «É estudar, saber as contas, saber ler». «Aprender serve para saber tudo para depois trabalhar» (A 5 B).

\section{Categoria: Rendimento escolar}

A maioria dos alunos de origem estrangeira (sete dos alunos entrevistados) situa o seu rendimento escolar num bom nivel (bom rendimento), considerando que são bons alunos. Os restantes três alunos pensam que o seu rendimento escolar é satisfatório, considerando que as suas notas são «mais ou menos boas».

\section{Categoria: Referência a hábitos e costumes do país de origem}

Apenas dois dos alunos inquiridos comunicam que nunca falam sobre os seus hábitos e costumes da sua terra natal.

Os outros alunos contam que falam muitas vezes ou algumas vezes sobre esses hábitos e costumes, principalmente sobre actividades que lá realizavam, palavras na sua língua materna e brincadeiras. Relativamente às brincadeiras, existe um intercâmbio entre os alunos entrevistados e os alunos portugueses, ou seja, os alunos estrangeiros ensinam as brincadeiras e jogos que conhecem características do seu país aos alunos portugueses e estes ensinam as nossas brincadeiras e jogos aos colegas de origem estrangeira. 
É de destacar que duas destas crianças referem que os seus professores demonstram interesse em conhecer e fazer com que partilhem os seus hábitos e costumes, dizendo:

- «Algumas vezes». «Sim [quando o professor pergunta]». «[Os outros meninos] gostam, depois eles no recreio estão sempre a dizer essas coisas, é por isso que eu não gosto de dizer todos os dias» (A 5 L).

- «É, [a professora às vezes pergunta] (...)». «[mas] eu não quero responder». «Tenho [vergonha]» $(\mathrm{A} 4 \mathrm{~B})$.

\section{BLOCO II - Relações interpessoais}

\section{Categoria: Relação com os colegas}

Quase todos os alunos informam que têm uma boa relação com os seus colegas, salientando que brincam com os seus amigos e amigas no recreio. Uma das crianças acrescenta ainda:

- «Dou-me bem, dou-me bem com eles, na minha terra, os meus amigos não eram assim, eram (...) todos maus para as pessoas, andam sempre assim todos zangados, o que têm a fazer não querem fazer, sempre assim, sempre tristes, mas aqui não, aqui são todos felizes sempre, e eu gosto de estar aqui». «Sim, [são todos meus amigos]» (A 1 L).

Somente uma das alunas menciona que tem uma relação menos boa com as suas colegas:

- «Mais ou menos, quando elas são minhas amigas, porque elas chamam-me nomes algumas vezes» (A $5 \mathrm{~L}$ ).

No que diz respeito às dificuldades sentidas no relacionamento com os colegas, oito dos alunos revelam que nos primeiros dias sentiram alguma dificuldade em estabelecer contacto com os seus colegas. Alguns dos alunos apontam a língua estrangeira como a principal dificuldade para estabelecer as relações, como podemos observar nas suas palavras:

- «Eu senti-me, quando eu não saber bem português, eu sentia-me... não me sentia bem e pensava que eles tinham piada de mim, que eu não sou assim, e pensava que eles não gostavam de mim» (A 1 L).

- «Demorou [uns dias para começar a brincar com eles porque não sabia falar bem o português], depois é que aprendi a falar português» (A 4 L). 
- «Demorou alguns dias [para brincar e falar com os colegas], um mês demorou para aprender» (A 5 L).

No entanto, não foram só alunos de países de leste a aludir a este problema:

- «No começo eu não sabia a língua deles, como eles falavam, não sabia as letras porque aqui eles falam as letras um pouco difícil, lá no Brasil não, é fácil para mim» (A 1 B).

Outros referem que, no princípio, não conheciam bem os colegas, mas que ultrapassaram a inibição inicial:

- «Senti [dificuldades] ». «Eu não conhecia, depois eu comecei a conhecer e gostei deles» (A 2 B).

- «Tive dificuldades durante uma semana, a conhecer eles bem aí depois eu fiquei a brincar, a participar» (A 3 B).

- «Eu fiquei com vergonha». «Foi assim: quando eu cheguei aqui tinha vergonha de vir à frente e depois eu fui para o recreio e fui brincando com eles até que fiquei amiguinho deles» (A 4 B).

\section{Categoria: Relação com o professor}

Grande parte dos alunos admite que mantém uma boa relação com o seu professor. As razões indicadas para esse bom relacionamento são diversas, como por exemplo, que «é amiga», que «é boa», que «ensina e ajuda» na realização dos trabalhos e «explica e ensina» o que não percebem.

Só um dos alunos considera que a sua relação com a professora é uma relação menos boa e explica:

- «Mais ou menos». «Porque ela às vezes ralha quando eu não faço bem» (A 4 L).

\section{BLOCO III - Desenvolvimento de competências cívicas}

\section{Categoria: Conhecimento de direitos e deveres da vida em comum}

Perante a diversidade de opiniões obtidas tentámos elaborar uma lista dos deveres do aluno em meio escolar, associando as respostas semelhantes dadas pelos alunos em três grupos distintos:

a) Cuidar do material e do espaço escolar «não sujar as mesas», «não estragar os livros», «usar os livros 
e material com cuidado», «deixar os espaços limpos e arrumados», «não deitar lixo para o chão», «não cuspir no chão», «não bagunçar as cadeiras», «descarregar a água do autoclismo», «tirar só uma gota de sabão» e «limpar aos toalhetes»;

b) Comportamento na sala de aula «levantar o dedo no ar antes de falar», «não assobiar e não gritar», «falar baixinho», «não correr e andar devagar», «não brincar com os colegas», «respeitar a professora e fazer aquilo que a professora manda», «obedecer», «respeitar as auxiliares», «deitar o lixo no caixote», «não riscar o quadro», «ser amigo, saber partilhar e ajudar os colegas», «respeitar o horário», «entrar com calma e falar baixo», «respeitar a fila» e «fazer os trabalhos de casa».

c) Comportamento no recreio

«não bater nos outros», «não andar às lutas», «brincar sem empurrar e sem bater», «não jogar com bolas duras», «jogar à bola no ringue», «não atirar lixo para o chão», «deitar o lixo no eco ponto ou no caixote», «não pegar nos caixotes do lixo», «respeitar as professoras», «respeitar as auxiliares», «não chatear e não mentir», «os meninos devem ser amigos», «não destruir as coisas que tem no recreio», «não pisar no jardim e regar as plantas», «não estourar os pacotes de leite», «não subir às árvores, nem às grades», «não arrancar folhas», «não ir para a horta», não cortar as florzinhas», «não sair da escola» e «cumprir as regras de segurança».

Nas entrevistas, os alunos inquiridos revelaram que tinham conhecimento não só dos seus deveres mas também dos seus direitos em meio escolar, os quais expomos em seguida, começando pelos que foram mencionados com maior frequência: «aprender», «ir ao recreio» e «brincar». Também foram referidos outros direitos: «falar/dar opinião», «beber o leite/lanchar», «trabalhar/estudar», «ir ao quarto de banho», «aguçar o lápis», «viver em são convívio no recreio e sala de aula», «ser assistido em caso de acidente», «ter a escola limpa e arrumada», «ter actividades de biblioteca», «ter actividades de ciência viva», «ser respeitada» e «dizer para a professora ajudar».

Ainda no âmbito do desenvolvimento da consciência cívica dos alunos, inquirimos as crianças no sentido de saber se tinham conhecimento dos seus deveres na vida em sociedade, pensando na sua (actual e futura) integração e participação na sociedade. Assim, foram referidos deveres 
relativos à boa educação e ao respeito pelo outro no convívio em sociedade:

- «Sim [devemos ser educados a falar com os outros]». «Sim [e respeitar os outros]» (A 1 L).

- «Eu acho que deve haver regras para não fazer asneiras porque se ele não tem regras são mal-educados». «Eu acho que é [respeitar] só aquelas que não fazem mal, que não querem prejudicar os outros». «Sim, [essas devemos respeitar] e não mentir» (A 2 L).

- «Sim [devo ser educada e simpática para os outros]»: (A 3 L).

- «Não se pode portar mal». «[Devemos tratar] bem [as outras pessoas], devemos ser bons e educados» (A 4 L).

- «Eu não me lembro mas sei que devemos respeitar as pessoas». «Acho que devemos respeitá-los [meninos diferentes] porque também são humanos como a gente» (A 1 B).

- « (...) falar bem com os outros, ser educado» (A 2 B).

- «Falar normalmente, direito, com educação [com as pessoas]» (A 3 B).

- «Falar bem [com as pessoas] e também quando a pessoa não souber o caminho para ir para algum lugar aí pergunta a outra pessoa e a outra pessoa explica bem direitinho» (A 4 B).

- «Não se pode gritar com elas, não se pode chamar nomes (...)» (A 5 B).

Também surgiram deveres relacionados com a preocupação da preservação do meio ambiente:

- «É preciso cumprir essa regra [não atirar lixo para o chão]» (A 1 L).

- «Não [posso deitar lixo para o chão]» (A 3 L).

- «Por exemplo, não posso arrancar folhas das árvores e depois deitá-las ao lixo, não deitar lixo para o chão (...)» (A 5 L).

- «Não se pode deitar lixo para o chão, (...) tem que reciclar os lixos (...)» (A 3 B).

Ainda obtivemos como resposta deveres ligados à prevenção rodoviária:

- «(..) tenho que esperar e olhar para o lado direito e para o esquerdo para atravessar a rua» (A $5 \mathrm{~L}$ ). 
- «Não andar de bicicleta na rua (...)» (A 2 B).

- «(..) quando tiver passado um carro a gente tem que esperar porque fica o sinal vermelho para a gente e depois vem o carro e depois quando fica verde para a gente, a gente pode passar e também não tem sinal nenhum e a gente passar e se não tiver passadeira, a gente tem que olhar para um lado e para o outro e passar» (A 4 B).

- «(..) tem que se olhar, para os lados antes de atravessar a rua $(\ldots) \gg(A)$

Tentámos apurar de que modo foi conseguido o envolvimento do aluno no reconhecimento desses direitos e deveres referidos anteriormente. Deste modo, apercebemo-nos que o nível de envolvimento não foi igual para todos os alunos entrevistados, existindo alguns casos em que os alunos participaram activamente na identificação dos seus direitos e deveres e outros casos em que esse envolvimento foi mínimo.

- «Sim, a gente começou a falar para a professora e a professora falava 'essa palavra não é essa'». «Escrevemos na cartolina e cortámos assim». «Foi [trabalho de grupo]». «A gente começou a fala e a escrever na sebenta, depois a professora disse como podia ser e acrescentou algumas coisas» (A 2 B).

- «Foi... eu descobri por mim mesma». «Tem aqui [essas regras escritas]». «Às vezes costumam [falar sobre problemas da sala], quando algum se porta mal (...)». «Costumam falar [sobre regras que se devem ter fora da escola]... a professora dá aula de civismo» «(...) é como se deve comportar as pessoas lá fora». «A gente fala e escreve no caderno, a professora às vezes manda nós fazermos regra de civismo (...) ao quadro para a gente fazer as regras de civismo e fazemos as regras no caderno». «Sim [ajudo a construir as regras]». «(...) no ano passado discutiram sobre esses direitos e deveres». «Escrevemos no caderno (...)» (A 3 B).

- «A professora contou-nos as regras e depois fizemos as regras». «Sim [escrevemos] no caderno». «Eu disse [mais uma regra], não se pode falar na aula». «Sim [toda a gente discutiu as regras]». «Falam [sobre as regras do recreio]». «Costumam [falar sobre regras de comportamento fora da escola]». «Falaram e discutiram [os direitos e deveres dos alunos]». «[escrevemos] no caderno». «Colocámos o dedo no ar [para dizer mais]». «Foi [todos discutiram juntos os direitos e deveres dos alunos]» (A 5 B). 
- «A professora escreveu um cartaz e falou sobre as regras da escola e a minha mãe também fala comigo (...)». «A gente fala umas coisas que ela perguntou e de resto (a professoral fala tudo». «Sim, é uma vez por semana que a professora fala nisso [problemas na sala de aula] e a gente também fala com ela». «Sim, [eu participo e dou a minha opinião» (A 1 B).

- «(..) nós escrevemos no caderno de linhas o que não se devia fazer na sala, o que era mau, o que não se devia fazer». «[A professora] fala e às vezes quando algum menino da sala bateu noutro (...) a professora ralha com eles $(. .). » . \ll(.$.$) às vezes a pro-$ fessora no fim da semana estamos ali a conversar sobre o que aconteceu, dos roubos e essas coisas». «Falamos de tudo, dizemos o que pensamos, não é só de roubos, é de tudo» ( 2 L).

- «Foi a professora que nos disse as regras, pergunta-nos as regras e nós dissemos». "Sim [ajudamos a dizer as regras]». «Sim [falamos como nos devemos comportar com os outros]» (A 1 L).

- «(..) tem vezes que quando a gente faz asneiras aí ela la professoral diz». «Sim [falamos nisso]». «É [falamos quando é preciso], a gente diz para a professora que um menino bateu na gente, que ele chamou palavrão». «Falam, a professora já falou [como nos devemos comportar fora da escola]» (A 4 B).

- «Sim, [a professora fala dessas regras]» (A 3 L).

- «Ninguém me disse essas regras. Eu aprendi sozinho». É, a professora diz como os meninos se devem comportar» (A $4 \mathrm{~L}$ ).

- «Ninguém [me disse sobre essas regras]. Quando os rapazes fazem as asneiras». «Sim, [nessa altura o professor fala]» (A 5 L).

\section{Categoria: Discussão de problemas da vida em sociedade}

A necessidade de estimular uma maior aproximação entre a escola e o meio envolvente é, actualmente, uma das preocupações no mundo educativo. De facto, é reconhecido que a abertura da escola à realidade do meio exterior constitui um meio de tornar as aprendizagens mais acessíveis e significativas para os alunos.

Através da opinião de oito dos alunos entrevistados podemos constatar que é usual conversarem e discutirem sobre problemas e acontecimentos da 
vida em sociedade, relacionados, principalmente, com notícias divulgadas pelos órgãos de comunicação social. Parece-nos, através da leitura das suas respostas, que os seus professores recorrem à utilização de notícias para provocar o debate e permitir a livre expressão da opinião dos alunos. No âmbito desta estratégia, um dos alunos expõe como realizou, com os seus colegas, um trabalho sobre uma notícia retirada de um jornal:

- «Criança morre em caso de acidente de viação». «É do jornal». «A gente trabalha em grupos e cada grupo deu a sua opinião. Um diz que ia a pé, outro que ia de bicicleta e isso assim». «Foi [deram soluções para essas coisas não voltarem a acontecer]». (A 2 B).

Em nossa opinião, consideramos que este modo de abordar as questões cívicas contribui para a reflexão, para a livre expressão de ideias e para tornar os alunos mais conscientes do seu papel de cidadãos, promovendo, deste modo, a sua identidade cívica.

Os alunos referem ainda que são tratados assuntos relacionados com problemas ambientais, sobretudo com a preservação da natureza, com a poluição e com o tratamento dos lixos.

\section{Bloco IV - Envolvimento dos pais com a comunidade escolar}

\section{Categoria: Opinião dos alunos sobre as razões pelas quais os pais/ lencarregados de educação gostam que eles frequentem a escola}

Todos os alunos revelam que os seus pais gostam que frequentem a escola em Portugal e ao analisarmos as respostas à questão sobre as razões pelas quais os seus pais gostam que eles frequentem a escola, constatámos que as principais razões indicadas são a aprendizagem da escrita, da leitura, a obtenção de novos conhecimentos, de regras e a convivência com os colegas e amigos. Uma das alunas entrevistadas salienta:

- «Gostam». «Porque eles gostam que eu ande na escola porque eu aprendo e quando aprendo coisas novas eu digo a eles (...)» (A 1 L).

Duas das opiniões revelam uma perspectiva futura da frequência da escola:

- «Gosta». «Porque é para mim estudar, para mim crescer e ter uma casa bem grande» (A 4 B). 
- «Gostam». «Porque eles querem que eu aprenda mais, porque eles querem que eu aprenda para ir para o Brasil outra vez, depressa» (A 5 B).

\section{Categoria: Apoio na realização dos trabalhos escolares}

A maior parte dos alunos diz-nos que os pais prestam apoio na realização dos trabalhos de casa.

Alguns dos alunos referem que fazem os trabalhos sozinhos e que solicitam a ajuda e colaboração dos pais (principalmente da mãe, na maior parte dos casos) apenas quando não compreendem o que têm para fazer e uma aluna, que também faz os trabalhos sozinha, espera que a mãe regresse do trabalho para tirar as suas dúvidas.

Alguns têm o apoio constante dos pais (principalmente da mãe) que explicam e os orientam na realização dos trabalhos. Uma das alunas obtém ajuda da mãe de origem brasileira e do marido da mãe, que é cidadão português, do seguinte modo:

- «Costuma [ajudar nos trabalhos de casa], ela é casada com um português, ele me explica sobre o Estudo do Meio aqui de Portugal e ela me explica as contas de Matemática e ela e ele me explicam as questões de Língua Portuguesa» (A 3 B).

Apenas uma das alunas afirma que os pais não prestam apoio na realização dos trabalhos porque:

- «Não». «Porque eu já sei fazer sozinha, eles não precisam de me ajudar» (A $1 \mathrm{~L})$.

\section{Categoria: Contactos estabelecidos pelos pais/encarregados de educação com a escola}

A maior parte dos alunos considera que os seus pais visitam a escola com pouca frequência, sobretudo para «saber as notas», «quando a professora chama» e «quando há reuniões». O contacto é estabelecido, na maior parte dos casos pelas mães das crianças. Dois dos alunos dizem-nos que os pais (mais a mãe) vão à escola com alguma frequência:

- «Para ver como estão os meus trabalhos e ver como eu estava na escola» (A 2 B). 
- «Vêm [muitas vezes à escola]». «Mais a minha mãe». «Para ver como estão os meus trabalhos e ver como eu estava na escola» (A 3 B).

\section{Categoria: Língua falada em casa com a família}

Relativamente à língua falada em casa pelos alunos de países de leste europeu, verificamos que todos eles falam a língua materna com a sua família, tal como suspeitávamos inicialmente, antes da realização das entrevistas.

\subsection{Síntese das ideias centrais do grupo de alunos}

Todos os alunos entrevistados afirmam que se sentem bem na escola e gostam de a frequentar, justificando essa posição com as seguintes razões: desejo de aprender «coisas novas», o convívio com os novos amigos e o facto de considerarem a escola «gira e boa». Apenas uma das alunas diz que gosta «mais ou menos» da escola devido à quantidade de trabalhos que leva para executar em casa.

Os alunos, no decorrer da entrevista, destacaram algumas das actividades escolares que mais gostam de realizar. Assim, os alunos de origem de leste mencionam com maior frequência as actividades de matemática, em seguida o desenho, e por último as actividades de educação física e a leitura. No caso dos alunos brasileiros não encontrámos uma resposta predominante e as actividades referidas são muito variadas: actividades de matemática e de língua portuguesa, de música, de pintura e desenho, estudar e as brincadeiras com os amigos.

Relativamente às actividades que os alunos não realizam na escola mas que gostariam de realizar, alguns alunos sugerem actividades, como por exemplo, brincar mais, fazer mais ginástica, fazer ginástica no pavilhão (ginástica com aparelhos e jogos de equipas, como o vólei e basquete), fazer mais desenhos e ir à escola todos os dias. Outros alunos não sugerem actividades, pois consideram que na escola já realizam todas as actividades de que gostam e que gostam de tudo o que fazem.

São mencionadas pelos alunos, como bons acontecimentos escolares, as seguintes situações: brincar no recreio com os colegas, ter amigos, fazer jogos com a professora, escrever, fazer desenhos, fazer visitas de estudo, aprender e estudar, ajudar os colegas nos trabalhos, as actividades 
no âmbito da «ciência divertida», as palestras realizadas na escola e as actividades de educação física. Quando questionados sobre os acontecimentos menos bons que acontecem na escola, os alunos referem a importância de conseguir estabelecer relações de amizade com os colegas na escola, que nos parece uma questão extremamente relevante na sua vivência escolar. Referem pontualmente algumas actividades escolares que não gostam muito de realizar, tais como trabalhos na área de estudo do meio, de gramática, trabalhos que requerem a utilização da tesourae actividades de educação física. São ainda mencionadas por uma das alunas algumas perturbações do ambiente da sala de aula, devido ao comportamento menos adequado de alguns colegas da turma.

A palavra aprender tem diferentes significados para os alunos entrevistados. Alguns dos alunos provenientes de países do leste europeu verbalizam opiniões que consideramos estar relacionadas com uma perspectiva de integração no nosso país, para outros a palavra significa vontade de saber mais, uma última opinião perspectiva um trabalho futuro.

Relativamente ao seu rendimento escolar, a maioria dos alunos de origem estrangeira (sete dos alunos entrevistados) situa o seu rendimento escolar num bom nível (bom rendimento), considerando que são bons alunos. Os restantes três alunos pensam que o seu rendimento escolar é satisfatório, considerando que as suas notas são «mais ou menos boas».

Apenas dois dos alunos inquiridos revelam que nunca fazem referência a hábitos e costumes da sua terra natal. Os outros alunos referem que falam muitas vezes ou algumas vezes sobre esses hábitos e costumes, principalmente sobre as actividades que lá realizavam, a explicação do significado de palavras da sua língua materna e a descrição das brincadeiras preferidas. Relativamente às brincadeiras, verificamos que existe uma partilha entre os alunos entrevistados e os alunos portugueses, ou seja, os alunos estrangeiros ensinam as brincadeiras e jogos que conhecem, características do seu país aos alunos portugueses e estes ensinam as nossas brincadeiras e jogos aos colegas de origem estrangeira. É de salientar que duas destas crianças referem que os seus professores demonstram interesse em conhecer e fazer com que partithem os seus hábitos e costumes, mas que devido à timidez e vergonha perante os colegas não partilham com eles as suas vivências.

Nove dos alunos confirmam que têm uma boa relação com os seus colegas (só uma aluna admite ter uma relação menos boa com os colegas), salientando que brincam com os seus amigos e amigas no recreio. Uma 
das crianças acrescenta ainda que gosta de frequentar a escola no nosso país porque acha que os seus novos amigos são crianças felizes.

Em relação às dificuldades sentidas no relacionamento com os colegas, oito dos alunos revelam que nos primeiros dias sentiram alguma dificuldade em estabelecer contacto com os seus colegas. Alguns dos alunos indicam a língua estrangeira como a principal dificuldade para estabelecer as relações interpessoais. No entanto, não foram só os alunos vindos de países do leste europeu a aludir a este problema, uma das alunas de origem brasileira referiu igualmente a dificuldade em comunicar com os seus novos colegas da turma. Outros mencionam que, no início, se sentiram inibidos, pois não conheciam bem os seus novos colegas, mas quando ultrapassaram essa inibição inicial começaram a participar nas brincadeiras e estabeleceram relações de amizade.

Grande parte dos alunos admite que mantém uma boa relação com o seu professor. As razões expostas para esse bom relacionamento são diversas, tais como, que «é amiga», que «é boa», que «ensina e ajuda» na realização dos trabalhos e que «explica e ensina» o que não percebem. Só um dos alunos considera que a sua relação com a professora é uma relação menos boa, explicando que a professora o repreende quando não realiza os trabalhos correctamente.

De um modo geral, todos os alunos demonstram ter conhecimento dos seus direitos e deveres da vida em comum. Perante a diversidade de opiniões obtidas sobre os deveres do aluno em meio escolar, tentámos elaborar uma lista desses deveres, associando as respostas semelhantes dadas pelos alunos em três grupos distintos:

a) Cuidar do material e do espaço escolar («não sujar as mesas», «não estragar os livros», «usar os livros e material com cuidado», «deixar os espaços limpos e arrumados», «não deitar lixo para o chão», «não cuspir no chão», «não bagunçar as cadeiras», «descarregar a água do autoclismo», «tirar só uma gota de sabão» e «limpar aos toalhetes»);

b) Comportamento na sala de aula («levantar o dedo no ar antes de falar», «não assobiar e não gritar», «falar baixinho», «não correr e andar devagar», «não brincar com os colegas», «respeitar a professora e fazer aquilo que a professora manda», «obedecer», «respeitar as auxiliares», «deitar o lixo no caixote», «não riscar o quadro», «ser amigo, saber partilhar e ajudar os colegas», «respeitar o horário», «entrar com calma e falar baixo», «respeitar a fila» e «fazer os trabalhos de casa»); 
c) Comportamento no recreio («não bater nos outros», «não andar às lutas», «brincar sem empurrar e sem bater», «não jogar com bolas duras», «jogar à bola no ringue», «não atirar lixo para o chão», «deitar o lixo no eco ponto ou no caixote», «não pegar nos caixotes do lixo», «respeitar as professoras», «respeitar as auxiliares», «não chatear e não mentir», «os meninos devem ser amigos», «não destruir as coisas que tem no recreio», «não pisar no jardim e regar as plantas», «não estourar os pacotes de leite», «não subir às árvores, nem às grades», «não arrancar folhas», «não ir para a horta», «não cortar as florzinhas», «não sair da escola» e «cumprir as regras de segurança».

Nas entrevistas, os alunos inquiridos revelaram que tinham conhecimento não só dos seus deveres mas também dos seus direitos em meio escolar, tendo sido referidos mais vezes os seguintes: «aprender», «ir ao recreio» e «brincar». Também foram mencionados outros direitos, tais como: «falar/dar opinião», «beber o leite/lanchar», «trabalhar/estudar», «ir ao quarto de banho», «aguçar o lápis», «viver em são convívio no recreio e sala de aula», «ser assistido em caso de acidente», «ter a escola limpa e arrumada», «ter actividades de biblioteca», «ter actividades de ciência viva», «ser respeitada» e «dizer para a professora ajudar».

Ainda no âmbito do desenvolvimento da consciência cívica dos alunos, inquirimos as crianças no sentido de saber se tinham conhecimento dos seus deveres na vida em sociedade, pensando na sua (actual e futura) integração e participação no meio social. Assim, foram referidos deveres relativos à boa educação no relacionamento entre as pessoas, ao respeito pelos outros no convívio em sociedade, deveres relacionados com a preservação da natureza e do meio ambiente e outros ligados à prevenção rodoviária.

Ao apurar de que modo foi envolvido o aluno no reconhecimento desses direitos e deveres da vida em comum, apercebemo-nos que o nível de envolvimento não foi igual para todos os alunos entrevistados, existindo alguns casos em que os alunos participaram activamente na identificação dos seus direitos e deveres e outros casos em que essa participação foi mínima.

A necessidade de estimular uma maior ligação e envolvimento entre a escola e o meio é, actualmente, uma das preocupações no mundo educativo, permitindo, desse modo, que a abertura da escola à realidade do meio exterior proporcione aprendizagens mais acessíveis e significativas 
para os alunos. Através da opinião de oito dos alunos entrevistados podemos constatar que é frequente conversarem e discutirem sobre problemas e acontecimentos da vida em sociedade através, principalmente, de notícias divulgadas pelos órgãos de comunicação social, acerca do meio local, nacional e até global. Parece-nos, através da leitura das suas respostas, que os seus professores recorrem à utilização de notícias para fomentar o debate e permitir a livre expressão da opinião dos alunos sobre os factos noticiados e sobre a resolução de problemas. No nosso parecer, consideramos que este modo de abordar as questões cívicas contribui para a reflexão, a livre expressão de ideias e para tornar os alunos mais conscientes do seu papel de cidadãos, promovendo, deste modo, a sua identidade cívica.

Os alunos salientam que são igualmente tratados assuntos relacionados com problemas ambientais, sobretudo com a preservação da natureza, com a poluição e com a separação e tratamento dos lixos.

Para além disso, consideramos que o sucesso da formação cívica dos alunos se deve basear em experiências activas de contacto com o meio, que promovam a responsabilização e a participação dos alunos em momentos de desenvolvimento de actividades de ligação da escola ao meio, com o objectivo de aquisição de comportamentos de cidadania.

Todos os alunos revelam que os seus pais gostam que frequentem a escola em Portugal e constatámos que as principais razões indicadas são a aprendizagem da escrita, da leitura, a obtenção de novos conhecimentos, de regras e a convivência com os colegas e amigos. Uma das alunas entrevistadas salienta que os seus pais gostam que ela frequente a escola porque assim quando aprende novos conhecimentos pode ensiná-los em casa. Duas das opiniões revelam uma perspectiva futura da frequência da escola lestudar para ter uma casa bem grande - vendo aqui a educação como factor de mobilidade social, e aprender mais para regressar ao Brasil).

A maior parte dos alunos diz-nos que os pais prestam apoio na realização dos trabalhos escolares. Alguns dos alunos referem que fazem os trabathos sozinhos e que apenas solicitam a ajuda e colaboração dos pais (principalmente da mãe, na maior parte dos casos) quando não compreendem o que têm para fazer e uma aluna, que também faz os trabalhos de casa sozinha, espera que a mãe regresse do trabalho para tirar as suas dúvidas. Outros alunos têm o apoio constante dos pais (principalmente da mãe) que explicam e os orientam na realização dos trabalhos. Uma das alunas obtém ajuda da mãe de origem brasileira na área de 
matemática e do marido da mãe, que é cidadão português, na área de estudo do meio, na área de língua portuguesa ambos prestam ajuda à aluna.

Apenas uma das alunas afirma que os pais não prestam apoio na realização dos trabalhos porque não necessita de ajuda, pois não sente dificuldade na realização dos trabalhos de casa.

Relativamente aos contactos estabelecidos pelos pais/encarregados de educação com a escola, a maior parte dos alunos considera que os seus pais visitam a escola com pouca frequência, sobretudo para ter conhecimento das notas, quando a professora solicita a comparência dos pais e quando há reuniões. O contacto é estabelecido, na maior parte dos casos pelas mães das crianças. Dois dos alunos dizem-nos que os pais (mais a mãe) vão à escola com alguma frequência para ver como estão os trabalhos que realizam na escola e para saber como se desenvolve o seu processo de ensino-aprendizagem.

Em relação à língua falada em casa pelos alunos de países de leste europeu, verificamos que todos eles falam a língua materna com os elementos da sua família, tal como suspeitávamos inicialmente, antes da realização das entrevistas.

\section{ANÁLISE QUALITATIVA AO GRUPO DE ENCARREGADOS DE EDUCAÇÃO}

Na análise realizada e aqui apresentada, apenas fazemos a distinção entre o grupo das entrevistas de países de leste e as entrevistas brasileiras quando consideramos que tal se justifica devido às diferentes opiniões e posturas entre os dois grupos de entrevistadas. Somente nesse caso apresentaremos em primeiro lugar as apreciações de um dos grupos e em seguida as de outro.

\section{BLOCO I - Percurso de imigração}

\section{Categoria: Anos de permanência em Portugal}

O tempo de permanência das entrevistadas no nosso país é diversificado. A encarregada de educação que habita há mais tempo em Portugal já se encontra aqui há dois anos e oito meses e a encarregada de educação com menos tempo de permanência vive no nosso país há um ano e meio. 
O tempo de permanência em Portugal referido nas entrevistas é contado até à data das mesmas, que decorreram entre 26 de Janeiro e 9 de Fevereiro de 2004.

\section{Categoria: Motivo da vinda para Portugal}

O motivo mencionado mais vezes pelas entrevistadas é a oportunidade de encontrar trabalho no nosso país, como podemos observar nas suas afirmações:

- «Para trabalhar, vem para trabalhar» (E 1 L).

- «Para ficar uma vida mais fácil. Para tentar fazer uma vida mais fácil». «Melhor do que nós tivemos no nosso país, que lá tem muito desemprego (...)» (E 4 L).

- «(...) a nível de trabalho, o meu marido lá no Brasil estava pior do que aqui (...). Como o meu pai é português, os meus irmãos já estão aqui há muitos anos, tenho um irmão que está aqui há 15 anos e está bem, então fomos vindo aos poucos, veio um irmão, por último veio meus pais, o meu pai que é português, que morava no Brasil há 47 anos já está de volta, então foi mais por motivos financeiros» (E 2 B).

- «Desemprego no país de origem» (E 3 B).

A troca do seu país de origem pelo nosso país tem também como motivo o desejo de uma vida melhor, como referem algumas entrevistadas:

- «Porque quero para mim e para a minha família vida melhor» (E 2 L).

- «Para ficar uma vida mais fácil. Para tentar fazer uma vida mais fácil». «Melhor do que nós tivemos no nosso país, que lá tem muito desemprego (...)» (E $4 \mathrm{~L})$.

- «Trocar país. Aqui vida mais calma e muitas coisas» (E 3 L).

Uma das entrevistadas apresenta como principal motivo da sua vinda as saudades que a sua filha tinha do marido e a insistência deste para que elas viessem juntar-se-lhe em Portugal onde se encontrava já a trabalhar:

- «0 motivo maior foi por o meu marido já estar aqui e a gente ficava lá no Brasil (...) e a [filha] sentia muito a falta do pai (...), aí ele insistiu tanto para a gente vir que aí resolvemos vir» (E 1 B). 


\section{Categoria: Composição do agregado familiar}

A maior parte das encarregadas de educação vivem com o marido e com o(s) filho(s).

Como excepção encontramos duas afirmações de duas entrevistadas. Uma delas refere que para além do marido e dos filhos vive ainda com a sua mãe e outra vive apenas com a sua filha.

\section{Categoria: Chegada a Portugal}

A análise das respostas dadas pelas entrevistadas permitiu-nos observar que, de um modo geral, o primeiro elemento do agregado familiar a imigrar para Portugal foi o pai do aluno (três dos casos) ou então pai e mãe ao mesmo tempo (dois dos casos). Em dois dos casos veio em primeiro lugar a mãe (no caso em que estão cá só mãe e filha e no caso em que a encarregada de educação casou com um cidadão português).

Constatámos que ocorreu o reagrupamento familiar ${ }^{11}$ quando os filhos se reuniram com os pais que já se encontravam a trabalhar no nosso país.

\section{Categoria: Integração no nosso país}

Quando questionadas sobre as dificuldades sentidas no dia-a-dia no nosso país, as entrevistadas com origem de países de Leste referem que a grande dificuldade foi a língua portuguesa, pois quando aqui chegaram não sabiam falar, nem entendiam a nossa língua. Duas das entrevistadas salientam que frequentaram um curso de língua portuguesa:

- «No início não sabia falar português e precisava de fazer curso de português mas acho que aprendi rápido e agora está tudo normal». «(...) língua estava mais importante para conseguir falar com as pessoas, precisava saber português» (E $1 \mathrm{~L})$.

- «Não tive grandes dificuldades. Claro que quando viemos não sabemos muito língua, tivemos que aprender, muitas coisas aprendemos no trabalho onde estamos. Depois andámos no curso no Porto, tirámos um curso de Língua Portuguesa» (E 4 L).

11. Segundo o Instituto Nacional de Estatística (INE), o reagrupamento familiar representou cerca de $24,2 \%$ dos motivos da entrada em território nacional da população estrangeira que solicitou estatuto de residente em 2001. 
As mesmas entrevistadas referem ainda que aprenderam rapidamente a nossa língua. Uma delas menciona o facto de, apesar de ter uma vida melhor em Portugal, o trabalho realizado é difícil e pesado:

- «Vida aqui melhor como eu pensei e só trabalho para mim mais difícil que na Rússia. Aqui nós estrangeiros empregados e não podemos estudar, só trabalhar e trabalho difícil e pesado. Se queres ganhar mais ou menos trabalhas muitas horas, doze horas. Se salário mínimo trabalhas oito horas» (E 3 L).

Relativamente às entrevistadas brasileiras, duas delas referem que sentiram dificuldades no início da sua permanência em Portugal. Ambas mencionam que sentiram algum preconceito e até discriminação no contacto com as pessoas e na procura de emprego.

- «No começo foi bem difícil. A gente sentia muito sozinho porque ele trabalhava, saía às seis da manhã e só voltava à noite (...). Então praticamente estava sozinha, eu saía com ela porque ainda não tinha escola e não conhecia ninguém, então a gente dava uma voltinha, tentava fazer umas amizades mas era bem difícil mesmo e até para ela também ficava muito sozinha (...). Aí graças a Deus a gente se começou a adaptar, não tanto, eu acho que sinto a falta da minha família toda lá, aqui só nós três, é muito difícil». «(..) foi muito difícil a gente fazer amizades aqui» (E 1 B).

- «Muita dificuldade, mas eu me adaptei bem. [A maior dificuldade foi] o preconceito, porque quando a gente chega numa loja pedindo emprego eles não acreditam na gente. Muita gente fechou a porta na minha cara, dizendo que não tinha vaga e eu sabia que tinha. Agora os meus filhos é que não estão muito habituados, principalmente o menino porque não tem calor para ele estar brincando na rua e ele sente muito a falta disso» (E 3 B).

Uma delas acrescenta ainda que se sentia muito sozinha e que foi um pouco difícil estabelecer relações de amizade, só conseguindo ultrapassar esta fase a partir do momento em que a sua filha começou a frequentar a escola portuguesa:

- «Só mesmo depois que ela começou a estudar, tive contacto com as mães, aí a gente começou a conversar». "Até comigo, mesmo na rua, a conversar com alguém, eu sinto assim um pouquinho, sei lá, não sei se é discriminação, não sei, quando eu vou falar, que eles vêem sotaque, fica assim, alguns lógico, tem também muita gente boa que eu encontrei aqui, meus vizinhos 
muito bom mesmo, mas eu sinto assim um pouquinho (...)». «Foi tudo difícil» (E1 B).

Apenas uma encarregada de educação afirma que não sentiu nenhuma dificuldade:

- «Nenhuma [dificuldade], nem em relação às pessoas que diziam que eram pessoas frias, que os portugueses eram frios, mais fechados, não vi nada disso, não são tão calorosos como os brasileiros mas não têm nada de frios» (E 2 B).

Quisemos ainda apurar se, apesar das dificuldades já mencionadas, encontraram facilidades na integração no nosso país. Assim, seis das entrevistadas (uma delas considera que não sentiu qualquer facilidade) revelam também as facilidades sentidas na sua permanência em Portugal: as amizades boas, a ajuda dos patrões na procura de casa, no preenchimento de documentos para trazer os filhos para Portugal e na procura de infantário para eles, a disponibilidade de ajuda dos vizinhos, a facilidade de relacionamento com as pessoas com quem convivem diariamente.

Em relação à língua falada em casa, entre os elementos que compõem - agregado familiar, as entrevistadas provenientes de países de leste dizem-nos que falam a sua língua materna. No entanto, duas das entrevistadas salientam o facto de que os filhos já esqueceram um pouco a língua materna, quando nos dizem:

- «Russo». «Ela (...) agora já um pouco trocar letras e palavras, já. Há um ano atrás ela escreve bom para russo agora não, muitas coisas não. Já melhor, mais ler e escrever para português. Quando eu pergunto» filha vai para mercado, o que é preciso comprar« ela escreve só português, palavras e letras português» (E 3 L).

- «Eu já chama-lhe Pedro, é raro quando chama de Petro ou o nome mais carinhoso na minha língua que é Petrika mas é pouca coisa. E em casa mesmo falamos já misturado, meio nossa língua, meio português. Às vezes falo qualquer coisa na nossa língua e ele diz 'ó mãe o que é isto', já esqueceram» (E 4 L).

Uma das entrevistadas brasileiras, a certa altura da entrevista, também refere:

- «Ela já está falando bem mais por ser criança também, ela às vezes chega em casa e começa a falar e eu digo 'fala brasileiro 
com a mamãe', que a gente conversa brasileiro, eu praticamente não peguei sotaque nenhum mas ela já (...). (...) apesar de ser o português mas tem coisas bem diferentes, o sotaque, tem coisas que eu realmente não entendo»(E 1 B).

\section{BLOCO II - Interesse pelo processo educativo do seu educando \\ Categoria - Apoio prestado ao educando nos trabalhos escolares}

Constatamos que cinco das entrevistadas afirmam que têm tempo disponível para prestar apoio aos seus filhos na realização dos trabalhos escolares que efectuam em casa. Apenas duas das entrevistadas referem que têm pouco tempo para prestar esse apoio:

- «Tem pouco. Claro que gostaria de ter mais, mas não tenho muitas possibilidades. Trabalho. De manhã até à noite, só vimos embora para casa para almoçar e depois vimos só à noite, mas ele anda no ATL (...). Às vezes vem com os trabalhos feitos (...) mas não pelo meu gosto, eu gosto de ter tudo direitinho, queremos que ele aprenda já de agora para depois ser mais fácil para eles próprios». «Ajudo, claro». «(...) pode ser que eu às vezes também não sei de tudo mas eu tento fazer tudo, vou ao dicionário e assim tento fazer correcto». «Ele gosta muito [de Matemática]. E sempre quando tenho tempo estou a treinar com ele» (E $4 \mathrm{~L}$ ).

- «Nem sempre. Porque são muitos [filhos] e pronto, são coisas diferentes e eu não consigo dizer tudo ao mesmo tempo» (E 2 B).

Estas encarregadas de educação expressaram ainda o modo de prestar apoio aos seus filhos. Três das entrevistadas prestam um apoio constante durante a realização dos trabalhos, estando ao lado deles, «vigiando» a realização dos trabalhos. Outras três referem que os filhos executam os trabalhos sozinhos e que chamam quando encontram dificuldades.

Apenas uma das encarregadas de educação não está com o seu filho em casa durante a realização dos trabalhos, no entanto, releva:

- «Às vezes vem com os trabalhos feitos [do ATL] (...) mas não pelo meu gosto, eu gosto que ele ter tudo direitinho (...)». «Ajudo [a corrigir], claro. Tem trabalhos que ele diz-me 'ó mãe aqui tens que me ajudar', ele diz-me logo quando vou buscá-lo 'ó mãe temos um trabalho para fazer juntos' (...)» (E $4 \mathrm{~L}$ ). 
Relativamente à ajuda prestada nos trabalhos das várias áreas curriculares, duas das entrevistadas expõem a sua dificuldade em apoiar os trabalhos da área de Língua Portuguesa:

- «Só ajudo Matemática, língua não, escrever não. Posso ler, posso escrever, só como ouço escrevo. Só Matemática» (E 3 L).

- «(..) eu estou sempre do lado dela ajudando e apoiando». «Pede [ajuda quando tem dificuldade], ou às vezes ela senta, todo o dia tem uma cópia então eu falo «você vai fazendo a cópia enquanto eu estou ocupada e depois a mamãe vai ver os erros» depois ela lê para mim mas sempre estou ali em contacto com ela». «(..) eu até tive que comprar um dicionário porque tinha coisas, exercícios que iam para casa que eu não sabia o que é que era (...)» (E 1 B).

\section{Categoria - Razões porque gosta que o seu educando frequente a escola}

Após a leitura das respostas a esta questão, encontramos diversas razões apontadas pelas encarregadas de educação para gostarem que os seus filhos frequentem a escola em Portugal.

Algumas entrevistadas salientam a importância da educação na vida dos seus filhos:

- «Sim, [gosto que frequente a escola]». «É importante, eu gosto muito desta escola. É importante a educação para tudo» (E 1 L).

- «Gosto». «Porque, ela aprende e tem que aprender. Se vive cá tem que aprender a língua e temos que respeitar a língua, tem que aprender porque também é mais fácil para ele conviver com os amigos aqui na escola e no ATL» (E $4 \mathrm{~L}$ ).

Outras das respostas dadas pelas entrevistadas destacam a satisfação do filho como a razão principal:

- «Sim, gosto». «Não sei, é boa professora, ele está contente, ele gosta dos colegas. Gosto» (E 2 L).

- «Gosto». «Não sei. Sempre contente». «Gosta. Gosta logo, nos primeiros dias quando vem para aqui. Para mim, isto muito bom, muito calmo» (E 3 L).

- «Gosto». «Ela está gostando muito, depois então que fez amizade, tem as amiguinhas dela, esta adorando» (E 1 B). 
Por último, surge-nos ainda o interesse/exigência demonstrado pela professora dos filhos:

- «Gosto». «Eu acho a escola muito boa, o ensino, a professora é muito atenciosa com ela, com todos, quando tem algum probleminha ela manda um recadinho ou pede para mim vir ou reuniões também eu estou sempre presente» (E 1 B).

- «Gosto». «Porque eu gosto das professoras, elas puxam muito pelos alunos, muito mais que lá na minha terra (...). Acho que são mais interessadas nas crianças, quando a gente vai conversar nas reuniões com as professoras se vê que as professoras estão mesmo interessadas que a criança aprenda e faça bem feito, não é, não só passe para o ano seguinte, preocupam-se com o que eles vão levar, então é isso que eu gosto, gosto muito daqui» (E 2 B).

- «Gosto». «Aqui as professoras são atenciosas, são boas. Ele, o meu filho demorou para se adaptar mais com os alunos porque veio de outro país e isso é normal mas agora está tudo bem. Eu gosto daqui» (E 3 B).

\section{BLOCO III - Envolvimento com a comunidade escolar \\ Categoria - Contactos com a professora do seu educando}

A partir das opiniões emitidas pelas entrevistadas, apercebemo-nos que todas demonstram interesse por manter um contacto regular com a professora do seu filho. No entanto, esse contacto é mantido de formas distintas. A maior parte das encarregadas de educação vai à escola por iniciativa própria e também quando é solicitada a sua presença pela professora.

Outras só vão à escola quando são solicitadas para participar nas reuniões ou quando surge qualquer assunto do seu interesse e do seu educando.

Apenas uma das inquiridas revela que nem sempre comparece, mesmo quando é solicitada devido à sua actividade profissional:

- «Nem sempre [venho quando a professora chama], quando há reunião muito importante eu venho. Quando penso isto muito importante eu venho». «No ano passado quase não cheguei para aqui porque tinha muito trabalho. Agora já tenho normal, oito horas e posso andar para aqui» (E $3 \mathrm{~L}$ ). 


\section{Categoria - Integração do seu educando na comunidade escolar}

Ao expressar a sua opinião sobre a relação dos filhos com os colegas e com a professora, todas as entrevistadas consideram que essa relação é boa e não revelam qualquer problema no relacionamento dos filhos com os colegas e com a sua professora. Pela análise efectuada parece- nos que duas das entrevistadas imigrantes de países do leste europeu consideram a questão do conhecimento da língua um factor facilitador do bom relacionamento entre os filhos e as crianças portuguesas ao afirmar:

- «Acho que está tudo bem. Também tem o problema da língua mas não é muito mau. Eu acho que está tudo bem, quando aprender mais a falar, vai melhor». «(...) ele gosta de ficar com crianças, de brincar (...)» (E 2 L).

- «Eu acho bom. Muito bom para amigos. Não tem problemas. Ela muito rápido conversa com amigos. Percebe ela, poucas palavras, já vai jogar, já vai conversar. Agora muito bom, já sabe português» (E 3 L).

A encarregada de educação que é mãe de duas das crianças entrevistadas de origem brasileira observa diferenças entre a sua filha e o seu filho no que diz respeito ao relacionamento com colegas e professoras:

- «É boa. Ela se adaptou muito bem, fez rápido amizade com as coleguinhas e com a professora também, tem até uma certa intimidade com a professora. Agora ele, até hoje acho que ele ainda não tem muita intimidade com a professora, tem medo, tem medo dos coleguinhas, é que ele é assim rude, é muito tímido» (E 3 B).

Relativamente à atenção e apoio dispensados ao educando pelas professoras, as encarregadas de educação consideram que os seus filhos recebem a devida atenção e apoio. Também pensam que as professoras conseguem que as crianças se sintam bem na escola e que gostem de frequentar a escola, que se preocupam com o facto de o aluno não conseguir perceber algo que esteja a ser explicado, que se preocupam em comunicar para casa quando surge algo do interesse do aluno e da encarregada de educação e também estão receptivas às mensagens que vêm de casa.

As entrevistadas reconhecem ainda o interesse das professoras pelo processo do ensino/aprendizagem das crianças, como podemos observar na seguinte opinião:

- «(..) as professoras estão mesmo interessadas que a criança aprenda e faça bem feito, não é, não só que passe para o ano 
seguinte, preocupam-se com o que eles vão levar (...)». «(...) eu acho que ela puxa muito por ele, ele se está desenvolvendo muito, ele amadureceu com ela» (E 2 B).

Uma das encarregadas de educação de origem brasileira comentou a atenção e apoio dispensados aos seus filhos na escola, no entanto, a sua observação é relativa ao ensino particular brasileiro que os filhos frequentavam antes da vinda para Portugal:

- «Comparando com o Brasil, porque no Brasil as professoras dão mais atenção, são mais atenciosas e eu acho que acompanham mais as crianças» (E 3 B).

Aliás, todas as entrevistadas brasileiras optaram por colocar os seus filhos no ensino particular no Brasil por considerarem que o ensino público brasileiro não é o melhor para o percurso escolar dos seus educandos.

As inquiridas emitiram a sua opinião sobre a integração dos seus educandos na escola que frequentam, dizendo que não sentiram qualquer problema nessa integração no meio escolar. Consideram que existe um bom relacionamento entre os filhos e os colegas e também com a professora e que os filhos gostam de frequentar a escola. Referem que os filhos estabeleceram relações de amizade com as crianças portuguesas sem dificuldade.

Apenas duas das entrevistadas, apesar de considerarem que a integração dos filhos se realizou sem problemas, referem:

- «Acho que sim [que a integração foi feita sem problemas], só mesmo a questão da língua, assim algumas palavras (...) ela está com essa dificuldade na hora de escrever (...) está trocando na hora da escrita, mas o resto está bem» (E 1 B).

- «Ele, o meu filho demorou para se adaptar mais com os alunos porque veio de outro país e isso é normal, mas agora está tudo bem» (E 3 B).

Esta última opinião diz respeito apenas ao filho da entrevistada, a qual tem também uma filha a frequentar a mesma escola. Sobre a integração da filha, a encarregada de educação afirma:

- «Ela se adaptou muito bem, fez rápido amizade com as coleguinhas e com a professora também, tem até uma certa intimidade com a professora» (E 3 B). 
De modo a tentar compreender um pouco melhor as expectativas das entrevistadas sobre a integração, questionámo-las no sentido de tentar auscultar, em seu entender, quais as medidas que poderiam ser postas em prática para uma melhor integração dos filhos nas escolas do $1 .{ }^{\circ}$ CEB.

A maior parte das entrevistadas (seis das inquiridas), pensa que as crianças estrangeiras deveriam ter aulas de apoio para uma melhor aprendizagem da Língua Portuguesa, considerando que seria uma medida que poderia proporcionar uma melhor integração. Mesmo as encarregadas de educação brasileiras entendem que seria benéfico o apoio, apesar de a língua por eles falada ser também a Língua Portuguesa, argumentando:

- «(..) o nosso alfabeto a gente fala totalmente diferente daqui $(\ldots) \gg(E 1 B)$.

- «A minha filha tem muita dificuldade sobre a língua portuguesa porque ela escreve o que fala e a pronúncia aqui é diferente porque o que a professora pergunta ela responde do jeito que ela fala, aí está com média baixa». «Eu acho que seria muito bom [se houvesse uma professora de apoio para a língua portuguesa» (E 3 B).

No entanto, e apesar de ter a mesma opinião, uma das entrevistadas diz acerca dos seus filhos (um no $1 .^{\circ}$ ano do $1 .^{\circ}$ CEB e outro no infantário):

- «Não era mau [ter mais apoio na língua portuguesa]». «Sim, [era bom que houvesse um professor de apoio para a língua portuguesa], mas eu acho como eles vieram muito cedo (...) já integraram no infantário, já tiveram educadoras, já acho que falam mais do que eu (...) não têm tantas dificuldades» (E 4 L).

Apenas uma das entrevistadas de origem brasileira considera:

- «Acho que não [seria necessário mais apoio para a língua portuguesa] porque são poucas coisas e são mais termos locais e também a criança vai pegando, os meus filhos pegaram muito rápido, sabe não é uma coisa que não é tudo diferente, são palavras semelhantes, eu acho que não» (E 2 B).

A mesma entrevistada sugere ainda uma actividade:

- «Lá, eu não sei se aqui existe isso, mas lá no Brasil tem a festa dos países. Um semestre era a festa da Itália, no outro... procurar as crianças que estão ali, as que tem mais logicamente, porque as crianças gosta de mostrar o que tem seu país delas, a comida, essas coisas. Ou fazer cada turma vai estudar um país, por exemplo o Brasil no caso dos meus filhos e então eles 
vão ficar entusiasmados, contentes porque são do Brasil, porque estão falando do país deles, «pode trazer alguma coisa, prato típico do Brasil que a gente aqui não conhece», e era uma maneira mais... e mostrar à escola toda (E 2 B)».

Uma encarregada de educação da Europa de leste expressa a sua preocupação com um possível esquecimento da língua materna por parte do seu filho:

- «Claro que a professora eu acho tem ajudado (...). Mas em casa gostava de poder ler e escrever ucraniano também. Eu gostaria de algum professor ucraniano para ensinar». "Sim, [uma professora que soubesse as duas línguas para ensinar]». «(..) para já tem que aprender melhor o português» (E 2 L).

Por último, é ainda sugerido a orientação da assistência social:

- «Eu acho que não é tanto culpa das professoras. Se tivesse tipo assistente social que estivesse aqui que orientasse mais, elas iriam fazer melhor. Elas fazem o que sabem, fazem o melhor que têm para fazer» (E 3 B).

\section{Categoria - Diferenças e semelhanças entre o ensino/escola do país de origem e o ensino/escola portuguesa}

Relativamente às opiniões que foram concedidas pelas entrevistadas acerca das semelhanças e diferenças entre o ensino do país de origem e o ensino ministrado em Portugal, surgiram duas diferentes situações: as entrevistadas cujos filhos já estavam a frequentar a escola no seu país de origem emitiram as suas opiniões relativas à experiência escolar dos seus filhos e à sua própria experiência como encarregadas de educação, enquanto outras, cujos filhos não chegaram, devido à sua pouca idade na altura da imigração, a frequentar a escola no país de origem, reportaram-se às suas próprias vivências enquanto estudantes.

Quanto às diferenças, apercebemo-nos que as encarregadas de educação oriundas de países de leste consideram que no nosso país o programa não é tão extenso, contém menos conteúdos programáticos como constatámos nas seguintes afirmações:

- «(..) na Bulgária se estuda muito material, onde aqui se aprende para dois anos, na Bulgária aprende um ano, aprende coisas mais rápido, fica mais difícil. Na Bulgária dá a multiplicação no $1 .{ }^{\circ}$ ano» (E $\left.1 \mathrm{~L}\right)$. 
- «Eu me lembro como eu estudava, lembro». «Desculpe, eu acho programa melhor na Rússia, mais efectivo. Porque eu acabo 11 anos, eu posso andar na Universidade e para mim já muito leve. É difícil falar isso eu não estava aqui» (E 3 L).

- «Eu acho que as nossas escolas são muito mais fortes. Mais exigente, mais forte, em pouco tempo aprender mais. Acho que no meu tempo já havia mais, agora neste tempo ainda mais (...) são muito exigentes» (E $4 \mathrm{~L}$ ).

Estas encarregadas de educação apontam ainda outras diferenças referindo certas características dos manuais escolares, a preocupação dos pais com os estudos, o horário e calendário escolar e os testes (fichas de avaliação).

- «Livros, aqui ele está a escrever nos livros, nós não, nós temos livros mas temos que escrever nas folhas, no caderno» (E 2 L).

- «Aqui é diferente, na nossa terra os pais preocupam-se mais com os estudos, de como é que ele vai. Até a professora diz que a turma dela não é muito forte e os pais não são muito interessados mas acho que não devia ser assim. Ou também não têm tempo, trabalham todo o dia». «E os livros aqui acho que muito bem feitos. Tem aquelas coisas para colar (...) tem aqueles autocolantes para colar naquelas coisas, acho que está bem pensado, bem feito» (E $4 \mathrm{~L}$ ).

- «Eu acho que a escola só de tarde ou só de manhã, como está, é melhor, as crianças pode descansar ou fazer outras coisas e na Bulgária não se faz testes, provas (...) tem dois semestres todo o ano, e lá tem semestres não tens testes e tens uma classificação de um até seis» (E $1 \mathrm{~L})$.

As encarregadas de educação brasileiras iniciaram a sua resposta relativamente às diferenças fazendo a comparação com a escola particular do Brasil que os filhos frequentavam:

- «Não sei, também a escola particular exige mais da criança. A professora dava mais atenção porque eram poucas crianças e eu estava pagando, a directora cobrava mais (...)» (E 1 B).

- «(...) nunca estudaram em escola do Estado e comparando a escola do Estado do Brasil com a escola daqui, esta daqui dá de dez a zero, esta daqui é muito boa, porque é assim, eu no Brasil nunca colocaria os meus filhos numa escola estadual e aqui coloquei porque o ensino é bom» (E $3 \mathrm{~B}$ ). 
- «(..) elas puxam muito pelos alunos, muito mais que lá na minha terra (...) mas eles puxam muito e coisa que escola pública não tem lá, lá se vai ao «Deus dará» como se diz lá. Acho que são mais interessadas nas crianças (...)». «(..) aqui puxam mais pela criança, são mais exigentes o que eu acho que é melhor, fazem a criança ter um sentido de responsabilidade que lá não tem. Lá se os pais puxam pela criança muito bem, se os pais não têm tempo ou um pingo de noção das coisas a criança anda um bocado perdida, então eu acho que aqui a escola faz isso». «(..) os professores puxam mais pelas crianças, lá é mais, eu acho que é mais abandonada» (E 2 B).

Após a leitura das respostas, ficámos com a ideia que as entrevistadas pensam que o ensino oficial português tem mais qualidade do que 0 ensino oficial do Brasil.

Quanto às semelhanças, não indicam concretamente as semelhanças que encontram, emitindo desta forma as suas opiniões:

- «(..) o ensino acho que é quase igual, as matérias...» (E 4 L).

- «É tudo parecido. Tirando essa... os professores puxam mais pelas crianças, lá é mais, eu acho que é mais abandonado» (E 1 B).

- «As escolas todas, se escolas têm que ter algumas coisas comuns, têm que ter, não é?» (E 2 B).

- «0 tipo de ensino, mesmo sendo de país diferente é mais ou menos igual» (E 3 B).

\subsection{Síntese das ideias centrais do grupo de encarregadas de educação}

A maioria das nossas entrevistadas veio para o nosso país com o objectivo de encontrar um trabalho que permitisse melhorar o seu nível financeiro de modo a proporcionar uma vida melhor à sua família.

Constatamos que, actualmente, a família nuclear das entrevistadas (pais e filhos) se encontra em Portugal, tendo já ocorrido o reagrupamento familiar com excepção de um caso em que a encarregada de educação vive apenas com a sua filha.

Encontramos diferentes formas relativamente ao processo de chegada a Portugal. Na maioria dos casos foi o pai da criança estrangeira o primeiro 
elemento da família a imigrar, vindo a mãe com os filhos mais tarde, noutros casos o pai e a mãe vieram juntos, indo posteriormente buscar os filhos ao país de origem, após ter a vida mais estabilizada e com melhores condições.

A questão da língua é apontada pelas inquiridas de países de leste da Europa como a principal dificuldade da sua integração no nosso país. Constatamos que actualmente, a maioria já se expressa relativamente bem na nossa língua, inclusivamente duas delas frequentaram um curso de língua portuguesa que as ajudou a ultrapassar essa dificuldade. Também foi identificada, por uma das entrevistadas, como uma dificuldade o tipo de trabalho realizado em Portugal, descrito como difícil e pesado devido às suas características e ao elevado número de horas exigido para obter um melhor salário (acima do salário mínimo).

As entrevistadas brasileiras (duas delas) sentiram algum preconceito e até discriminação o que dificultou o seu processo de integração.

Uma das opiniões emitidas remete-nos para a ideia em que a questão da integração das famílias imigrantes pode ser realizada de uma forma mais efectiva, a partir do momento em que começam a usufruir dos serviços de algumas instituições, neste caso a instituição escola.

Quanto às facilidades sentidas salientam-se as boas amizades estabelecidas em Portugal, a disponibilidade de ajuda por parte dos vizinhos e até de patrões e a facilidade de relacionamento com outras pessoas.

Parece-nos que estas imigrantes se sentem bem no nosso país. Apenas uma de origem brasileira, que apesar de dizer que está satisfeita, já no final da entrevista, confidenciou-nos que já pensou em regressar com a filha, pois sente muito a falta do apoio familiar e a nível financeiro está a passar dificuldades (o marido sofreu um acidente, ela não pode trabalhar devido a uma gravidez de risco).

Tal como esperávamos, em casa os elementos do agregado familiar das encarregadas de educação de países do leste europeu falam a língua materna, no entanto algumas das entrevistadas (duas) mostram-se preocupadas pela possibilidade de os seus filhos esquecerem a língua materna. Esta preocupação é compreensível pois a língua não é apenas um instrumento de comunicação, ela faz parte da identidade cultural de um povo e, por isso é necessário aceitar os diferentes modos e capacidades de comunicação e relação. 
Todas as entrevistadas revelam que gostam que os filhos frequentem a escola portuguesa. Como razões justificativas para esse facto, indicam-nos a importância da educação, a satisfação dos filhos na frequência da sua escola e o interesse e exigência das professoras dos seus filhos. Esta última razão é também apontada como uma das principais diferenças entre o ensino oficial português que as crianças frequentam e o ensino oficial brasileiro, como veremos mais adiante.

Todas as entrevistadas revelam interesse pelo processo educativo dos filhos e as que nos dizem que têm tempo disponível prestam apoio e ajudam os seus filhos nos trabalhos escolares realizados em casa. Esse apoio é prestado de diferentes formas: um apoio constante, apoio quando são chamadas para ajudar e mesmo uma das encarregadas de educação que não está em casa com o filho, o qual realiza os trabalhos no ATL, tem a preocupação de verificar se estão certos.

Em relação aos trabalhos na área de língua portuguesa, verificamos que uma entrevistada de leste não se sente apta para os orientar, pois tem ainda alguma dificuldade na expressão escrita na língua portuguesa. Contudo o que nos admirou foi também esta questão surgir por parte de uma encarregada de educação brasileira, apesar de a língua ser a mesma.

A maioria das entrevistadas mantém um contacto regular com a professora do filho, porém, esse contacto é efectuado de diversas formas: por iniciativa própria e quando são solicitadas para comparecer na escola, apenas quando são solicitadas e uma das encarregadas de educação confidencia-nos que nem sempre comparece na escola, mesmo quando solicitada, pois por motivos profissionais nem sempre está disponível.

Todas as entrevistadas consideram que a relação dos filhos com os colegas e com a professora é boa, não apontando qualquer tipo de problema nesse relacionamento. A questão do conhecimento da língua portuguesa é considerada pelas imigrantes de leste como um factor facilitador do bom relacionamento entre as crianças estrangeiras e as portuguesas.

As encarregadas de educação pensam que os seus filhos recebem a necessária atenção e apoio por parte das suas professoras, comentando que estas proporcionam um ambiente acolhedor, fazendo com que as crianças estrangeiras se sintam bem na escola. Referem ainda que as professoras se preocupam e se esforçam por explicar, quando o aluno estrangeiro não entende algo, comunicam com as entrevistadas sempre que consideram necessário, mostrando-se receptivas em relação 
às mensagens que vêm de casa. É ainda valorizado o interesse demonstrado pelas professoras em relação ao processo de ensino/aprendizagem das crianças.

Expondo a sua opinião sobre a integração dos seus filhos, as entrevistadas consideram que não existiu qualquer tipo de problemas na integração das crianças no meio escolar. Os seus filhos estabeleceram com facilidade relações de amizade com os seus colegas portugueses, existindo um bom relacionamento entre eles e com as respectivas professoras.

A maioria das entrevistadas, quer brasileiras quer de países de leste, considera que as aulas de apoio na língua portuguesa poderiam contribuir para uma melhor integração das crianças estrangeiras.

Uma das entrevistadas, originária de um país de leste europeu, sugere que seria estimulante que este apoio fosse ministrado por um professor que dominasse as duas línguas, a portuguesa e a do país de origem, de modo a permitir que as crianças não esquecessem por completo a língua do país de origem.

Para além do apoio, são referidas outras medidas para uma melhor integração: prática de actividades escolares de valorização da cultura do país de origem, envolvendo todos os alunos da escola e a intervenção da assistência social.

As encarregadas de educação vindas de países do leste da Europa, quando confrontadas a avaliar o ensino oficial português do $1 .{ }^{\circ} \mathrm{CEB}$ comparativamente ao ensino oficial do país de origem, apontam algumas diferenças: em Portugal existem menos conteúdos programáticos, o ensino é mais exigente nos países de origem, em menos tempo aprendem mais; referem também os manuais escolares em relação à sua utilização (não escrevem nos livros mas sim nos cadernos), elogiam a apresentação e a forma como estão elaborados os manuais do $1 .{ }^{\circ}$ CEB portugueses.

As entrevistadas brasileiras também encontram algumas diferenças entre o ensino oficial brasileiro e aquele que é ministrado em Portugal. A principal diferença encontrada reside na qualidade do ensino português, onde encontram mais disponibilidade e interesse por parte dos professores portugueses, maior empenho em fazer compreender os conteúdos programáticos, maior exigência por parte dos docentes portugueses, que resulta num maior desenvolvimento e sentido de responsabilidade por parte dos alunos. 


\section{CRUZAMENTO DE ALGUNS DADOS OBTIDOS NAS ENTREVISTAS}

Como referimos no ponto 2 deste capítulo, quando analisámos o interesse e apoio nas actividades escolares revelado pelos pais, uma grande parte dos professores considera que os pais são interessados, comparecendo na escola sempre que consideram necessário e/ou sempre que são solicitados e nas reuniões periódicas que efectuam. Apenas um professor lamentou o facto de ainda não conhecer os pais da sua aluna mas que compreendia que ainda não tivessem vindo à escola por motivos profissionais. Relativamente ao acompanhamento e apoio prestado aos filhos nas actividades escolares, as opiniões dos docentes divergem, alguns professores dizem que os pais ajudam nos trabalhos de casa, outros dizem que os pais apenas orientam e verificam se o filho fez ou não os trabalhos e por último, outros docentes manifestaram o seu descontentamento relativamente ao interesse dos pais dizendo que os seus alunos não são acompanhados nos trabalhos de casa e que os realizam sozinhos. Afirmamos, então, que considerando a variedade de respostas, não podíamos tirar conclusões, nem emitir qualquer tipo de juízo. Agora, neste ponto do trabalho podemos tentar cruzar essas opiniões recolhidas com as respostas dadas pelas encarregadas de educação, para tentar apurar quais os motivos porque não acompanham e não prestam apoio aos filhos, e no caso de acompanharem e prestarem apoio em casa tentar saber quais as dificuldades que encontram nessa tarefa. Assim, as encarregadas de educação que referem que têm pouco tempo para prestar esse apoio, afirmam que devido ao horário do trabalho (com muitas horas de trabalhol não têm muitas possibilidades de acompanhar como gostariam os seus filhos na realização dos trabalhos escolares, um dos alunos até os executa no ATL, mas a mãe, à noite, verifica se estão todos feitos e se estão correctos.

Relativamente à dificuldade em prestar ajuda nos trabalhos das várias áreas curriculares, apenas duas das entrevistadas expõem a sua dificuldade em apoiar os trabalhos da área de Língua Portuguesa, uma entrevistada de nacionalidade russa, que só ajuda na área de matemática porque não se sente com capacidade para auxiliar correctamente na língua portuguesa, e outra entrevistada de nacionalidade brasileira, que nos diz que tem dificuldade na compreensão do significado de certas palavras.

No que diz respeito à língua falada em casa pelos alunos de países de leste europeu, todas as crianças nos disseram que falavam a língua materna com a sua família. No entanto, confrontando estas opiniões com as informações reveladas pelas encarregadas de educação verificamos que duas das entrevistadas salientam o facto de que os filhos já esquece- 
ram um pouco a língua materna. Uma delas afirmou que a sua filha já troca algumas letras e palavras e que já lê e escreve melhor em português do que em russo, enquanto outra encarregada de educação salientou que em casa falam uma «mistura» das duas línguas (moldavo e português), pois quando fala somente em moldavo os seus filhos (só um é que frequenta o 1. CEB, o outro frequenta o jardim de infâncial já não conseguem compreender.

Observámos na análise das entrevistas que no caso de crianças vindas de países de leste, cujos nomes são de difícil pronúncia, foi feita uma adaptação para nomes portugueses, não só na escola, mas, em alguns casos, também em casa.

Uma das encarregadas de educação brasileira conversa em casa com a sua família com o sotaque brasileiro, mas pensa que a sua filha está a perder esse sotaque e começa já a falar um português com uma pronúncia correcta, o que por vezes dificulta a comunicação entre as duas, chegando mesmo a pedir à sua filha para falar com o sotaque brasileiro. 


\section{REFLEXÕES E CONSIDERAC̣ÕES FINAIS}

Visamos, na fase final deste trabalho, acentuar alguns dos aspectos que mais se destacaram e as mensagens que consideramos mais relevantes, em relação à temática que foi explorada - a construção da cidadania em contexto intercultural e o papel do professor nesse processo - contemplados nos vários capítulos que constituem esta dissertação.

Assim, no capítulo I, evidenciámos a questão das migrações que tem vindo a provocar alterações na nossa sociedade. Salientámos os principais factores das migrações, a especificidade de Portugal como país de emigração/imigração, contextualizando o fenómeno da imigração portuguesa a nível europeu e mundial e analisámos a evolução das políticas de imigração no nosso país nos últimos anos, fazendo referência ainda às orientações do Conselho da Europa sobre esta questão. Destacámos a urgência de uma comunicação e compreensão intercultural para aprender a reconhecer a presença da diversidade das diferentes culturas, pois esta mistura de culturas, consequência das migrações, evidencia as dificuldades de integração de indivíduos caracterizados como desiguais por serem diferentes. Assim, reflectimos sobre a necessidade de integração na sociedade portuguesa das famílias de imigrantes e sobre o desafio que as migrações apresentam à instituição escolar para assegurar o sucesso educativo e o sucesso humano das crianças filhas de imigrantes, cujo número tem aumentado nas escolas portuguesas nestes últimos anos. Apresentámos a evolução das políticas educativas face à diversidade cultural no nosso país e também algumas directrizes produzidas por organizações internacionais que se preocupam com esta questão. Salientámos a importância da prática de uma educação intercultural, como facilitadora da integração das crianças com culturas diferentes, traçando um breve percurso da educação monocultural à educação multicultural e intercultural e reflectimos ainda sobre o papel do professor em todo este processo. Por último, analisámos a relação entre a educação intercultural e a educação para a cidadania, expondo os motivos porque consideramos que educação para a cidadania e a educação intercultural estão intimamente relacionadas e se apoiam mutuamente.

No capítulo II, pretendemos esclarecer que a cidadania é um conceito complexo, podendo ser perspectivado em múltiplas vertentes. Explorámos diversas concepções de cidadania, fazendo uma breve análise ao longo dos tempos e destacámos a abordagem liberal de cidadania que tem sido a concepção dominante na maioria das democracias ocidentais desde a segunda guerra mundial. Apresentámos a opinião de diversos autores que consideram que face à inevitabilidade e iminência dos fenó- 
menos migratórios internacionais, que envolve a questão dos direitos de cidadania dos imigrantes, e à aceleração da globalização, o paradigma moderno de cidadania se tornou desactualizado e expomos as suas propostas para a mudança necessária, no sentido da construção e do exercício de uma cidadania mais emancipatória.

Evidenciámos que a escola face à cidadania é uma incontornável problemática da actualidade e que a noção de educação se encontra intimamente ligada ao conceito de cidadania. Consideramos que é fundamental que a sociedade crie justiça e igualdade de oportunidades pela educação, para que todos possam desfrutar de um desenvolvimento social e humano mais justo. Actualmente, emerge uma prática cívica que deve abranger todos, o que obriga a realçar o papel da educação na formação do futuro cidadão. É nesse sentido que podemos afirmar que toda a educação deve ser orientada para a promoção de uma cidadania activa.

Pareceu-nos igualmente importante reflectir sobre a cidadania em contexto intercultural pois aprendemos a ser, a compreender, a conhecer e a viver juntos, partindo da diferença para a igualdade e da pluralidade para a identidade e o direito à educação permite a verdadeira relação entre o idêntico e o diferente, entre o universal e o particular. Apresentámos vários conceitos, segundo alguns autores, da educação para a cidadania. Salientámos as implicações da reorganizacão curricular lcom a entrada em vigor do Decreto-Lei n. 6/2001, de 18 de Janeirol na prática pedagógica, no âmbito da educação para a cidadania.

Dado que um dos fenómenos evidente na sociedade em que vivemos é a chamada crise de valores, considerámos importante reflectir sobre essa questão pois uma modificação a esse nível acaba por se repercutir na mundividência escolar. Terminámos este capítulo com uma reflexão sobre o papel do professor do $1 .{ }^{\circ}$ CEB na implementação e no desenvolvimento da educação para a cidadania, pois, conscientes das transformações que ocorrem actualmente e outras que ocorrerão no futuro a nível nacional, europeu e mundial, pensamos que é da maior importância o reforço da ideia de cidadania e uma maior eficácia na sua promoção nas nossas escolas. Perante estas exigências, é fundamental, enquanto professores do 1. ${ }^{\circ}$ CEB, acompanharmos com a devida atenção as propostas e inovações nesta área, de modo a podermos actuar com a competência indispensável à promoção de uma educação que aspire a formação integral do aluno como ser humano, consumando, deste modo, a nossa missão de verdadeiros educadores, considerando a educação para a cidadania como uma condição de sucesso do nosso trabalho pedagógico. No capítulo III, abordámos a questão dos desafios criados 
pela legislação e pelos documentos orientadores das políticas educativas mais recentes em Portugal, salientando a reorganização curricular do ensino básico que assinala uma mudança importante no modelo curricular do nosso país. Destacámos ainda algumas orientações a nível internacional para a questão da cidadania em contexto escolar.

No capítulo IV, defendemos as nossas opções metodológicas da investigação e tratámos de uma forma aprofundada as opiniões recolhidas através das entrevistas semi-directivas aos três grupos em estudo: professores, alunos e encarregadas de educação. No capítulo V, apresentámos, interpretámos e analisámos essas opiniões recolhidas.

Consideramos ser este o momento de recordar as questões de investigação, formuladas inicialmente e tentar dar-lhes resposta, através da exposição das ideias principais obtidas com este trabalho.

No nosso parecer, o quadro legal e o conteúdo dos discursos da política educativa que analisámos indicam uma educação intercultural impeditiva de situações de exclusão, uma preocupação com o número crescente de crianças imigrantes nas escolas e de uma educação para a cidadania direccionada no sentido de estimular o desenvolvimento, nas crianças e jovens, das suas competências de cidadãos construtivamente intervenientes, acompanhando a realidade da sociedade portuguesa e das nossas escolas. De facto, são evidentes os esforços patentes nas políticas educativas no que respeita à construção progressiva da escola democrática e da implementação efectiva e consistente de uma educação para a cidadania. Contudo, apesar das reformas do sistema educativo e da reorganização curricular veicularem discursos que apontam para a educação para a cidadania e para a redução da desigualdade na escola em consequência das diversidades culturais, a escola democrática ainda não saiu totalmente do âmbito da ideologia, dos discursos e das intenções. Parece-nos que, na prática, a escola vive ainda uma tensão entre a uniformização e a diversificação, entre a tradição e as pedagogias interculturais.

Em relação à educação intercultural, na prática pedagógica ela é identificada pelos professores como um contributo para o sucesso escolar dos alunos com diferentes culturas, pois esta facilita o intercâmbio de vivências e de conhecimentos, fomenta o enriquecimento dos alunos a nível cultural, contribui para a valorização e para a não discriminação do aluno estrangeiro, favorece a criação de um ambiente de sala de aula estável, acolhedor e respeitador, e, finalmente, o contacto com diferentes culturas motiva a inter ajuda entre todos os alunos e facilita a aprendizagem escolar. Apesar disso, a maioria dos docentes revela ter pouco conheci- 
mento de orientações/directrizes do Ministério da Educação para a educação intercultural. É realçada a vertente da ajuda do aluno estrangeiro na integração, ressaltando também que a nível de legislação está previsto o apoio na aprendizagem da Língua Portuguesa como segunda língua aos alunos cuja língua materna não seja o português, no entanto, na realidade escolar esse apoio não se concretiza ou quando existe é insuficiente. Destacam ainda que se deve aceitar a realidade social do aluno, a sua forma de estar e que é necessário conhecer bem a sua cultura de origem. Porém, para que essas directrizes saíssem do contexto legislativo era necessário mais apoio la nível da língua portuguesa, a nível de equipamento e a nível da criação de equipas de apoio).

Nas opiniões recolhidas do grupo de professores entrevistados predomina a ideia que a diversidade cultural é uma mais-valia para o trabalho pedagógico, que é enriquecedor a nível de aquisição de vocabulário, a nível do desenvolvimento da oralidade, possibilitando ainda a partilha de conhecimentos e a obtenção de novos saberes sobre países e culturas diferentes da nossa. A dificuldade na comunicação oral entre professores e alunos do leste europeu a nível do significado das palavras é apontada como uma dificuldade sentida perante a diversidade presente na sala de aula. A comunicação escrita é igualmente referida como uma dificuldade, principalmente no caso dos alunos brasileiros, que geralmente escrevem como falam, na opinião dos seus professores. Outro género de dificuldades mencionado é relativo a características do próprio aluno que tornam a partilha de vivências e de conhecimentos um pouco difícil, apesar das solicitações dos seus professores. É ainda identificada como dificuldade a falta de preparação das escolas para atender casos de alunos estrangeiros, sobretudo a nível da não existência de professores de apoio para ajudar estes alunos na aprendizagem da língua portuguesa. É também mencionado que sem uma modificação no currículo formal não se pode realizar uma intervenção a nível das diferenças culturais no desenvolvimento do trabalho escolar.

Todos os professores entrevistados pensam que a língua não pode ser um impedimento ao sucesso escolar do aluno estrangeiro. No entanto, alguns dos professores consideram que a língua pode ser encarada como um obstáculo à expressão do aluno em português correcto e para a compreensão do significado de palavras. Os entrevistados expressam ainda a sua preocupação pelo facto de o aluno fora da escola não aprender a falar o português correcto.

Relativamente à educação para a cidadania, de um modo geral, os professores entrevistados têm conhecimento ou algum conhecimento das 
orientações/directrizes do Ministério da Educação para a educação para a cidadania expressas no Decreto-Lei n. ${ }^{0}$ 6/2001, sabendo da criação das três novas áreas curriculares não disciplinares, das quais destacam a área de formação cívica. Para além da informação que possuem por meio da legislação alguns dos professores também se documentaram em jornais de âmbito educativo e em manuais publicados pelo Ministério da Educação.

Os docentes entrevistados almejam a formação global das crianças como seres humanos e manifestam nos seus discursos, a necessidade da formação do futuro cidadão responsável, autónomo, crítico, activo e solidário, indo de encontro aos princípios legislativos expressos no Decreto- Lei n. ${ }^{\circ}$ 6/2001 para a educação para a cidadania, destacando também a sua dimensão intercultural. Assim, todos os entrevistados consideram que a educação para a cidadania tem um papel muito importante e fundamental para o enriquecimento global das crianças como pessoas, para o desenvolvimento global da personalidade e que o processo de socialização dos alunos implica a formação de uma consciência cívica.

Os professores consideram muito importante a prática da educação para a cidadania no meio escolar, exprimindo que a educação para a cidadania é um complemento da educação dada pela família, ajuda o aluno na construção da sua personalidade, promove a igualdade e o respeito pelos outros, é um investimento para o futuro e uma preparação para a vida em sociedade.

O reconhecimento de que a escola e o professor têm um papel fundamental a desempenhar na educação para a cidadania é um ponto que obteve consenso. As opiniões dos entrevistados revelam ainda que a responsabilidade da escola e do professor na educação para a cidadania é grande e consideram que o professor do $1 .{ }^{\circ}$ CEB desde sempre se preocupou com esta questão, mesmo antes de estar contemplada na reorganização curricular e da criação da área de formação cívica, através do Decreto-Lei nº. 6/2001, de 18 de Janeiro. A sensibilização das crianças para as questões da cidadania é essencial desde o início da escolaridade, realizada através da vivência de situações práticas que ajudem a desenvolver competências cívicas, contactando com situações reais do mundo em que vivem. Alguns professores expressam ainda a sua preocupação pelo papel pouco activo da família nas questões de cidadania ponderando que, por vezes, pode existir um processo conflituoso entre as práticas aconselhadas pela escola e as práticas recomendadas pela família.

Quanto à forma de colocar em prática a educação para a cidadania, os docentes evidenciam preferência pela via da formação transversal, 
concretizando-a através da disseminação dos seus objectivos pelas diferentes áreas dos planos curriculares. Esta forma é igualmente defendida por alguns autores mencionados neste trabalho, os quais alegam que a educação para a cidadania deve fazer parte de todas as áreas disciplinares, deve estar em toda a escola e em cada a pessoa que a compõe. Os professores também colocam em prática a educação para a cidadania quando decidem aproveitar o momento em que surge uma situação oportuna, quando optam pelo desenvolvimento de um projecto de natureza interdisciplinar no âmbito desta área ou ainda utilizam a ocasião proporcionada por datas ou dias comemorativos. São poucos os professores que escolhem a via do espaço curricular próprio, designado por área de formação cívica, uma área curricular não disciplinar, com o apoio de um tempo semanal para sessões de informação e de debate que pode assumir o formato de assembleia de turma. Apesar dos docentes terem evidenciado a sua preferência por um dos modos de colocar em prática a educação para a cidadania, a maioria dos entrevistados utiliza, no seu trabalho pedagógico no âmbito da educação para a cidadania, uma conjugação de alguns desses modos referidos anteriormente. Todos os professores entrevistados consideram que os currículos das várias áreas disciplinares promovem e contribuem para a educação para a cidadania. O currículo da área de Estudo do Meio é o mais mencionado como o que mais promove e o que mais contribui para a educação para a cidadania, no entanto, também são mencionados os currículos de Língua Portuguesa, por abranger textos com temas e mensagens referentes a valores cívicos, e de Matemática que, na opinião dos docentes, pode auxiliar os alunos a ultrapassar determinadas dificuldades e pode contribuir para a resolução de dificuldades do dia-a-dia.

A maioria dos professores admite que sente necessidade de formação no âmbito da educação para a cidadania para obtenção de novos conhecimentos, de materiais específicos e de ideias inovadoras sobre como trabalhar e explorar esta área, para se envolver na partilha de experiências e troca de conhecimentos entre professores e para fugir à rotina do trabalho pedagógico usualmente realizado. Algumas das opiniões recolhidas salientam que a planificação em conjunto com colegas permite a troca de ideias e que para colmatar a falta de formação se pode pesquisar em livros de modo a obter o conhecimento que necessitam para melhor trabalhar com os seus alunos.

Todos os inquiridos reconhecem a grande importância das aprendizagens dos seus alunos no âmbito da educação para a cidadania. Os professores justificam a atribuição dessa importância relacionando-a com o desenvolvimento integral do aluno e a sua formação como pessoa e futuro cidadão. 
Para os professores entrevistados, o impacto das aprendizagens realizadas no âmbito da educação para a cidadania nos alunos dizem respeito a mudança de atitudes e comportamentos, podendo observar-se resultados positivos a nível individual no bom comportamento, no cumprimento das regras da escola e na boa utilização das instalações escolares, e também a nível colectivo ligado ao bom relacionamento entre os alunos e ao comportamento na sala de aula e no recreio. De acordo com algumas das opiniões, esta mudança de atitudes a nível individual pode mais tarde implicar uma transformação da sociedade no sentido de a melhorar e de a tornar mais justa e mais humana.

Todos os docentes afirmam que têm vindo a verificar que há uma maior preocupação e envolvimento dos alunos com as questões da cidadania, pois ao desenvolverem o sentido da responsabilidade, empenham-se mais na vida colectiva da turma e também da escola. Declaram ainda que os seus alunos vão interiorizando aos poucos uma consciência de cidadania, no que diz respeito à manifestação de atitudes correctas, à distinção do certo e do errado, à sua capacidade para medir atitudes de modo a não prejudicar o outro, à interiorização das regras mais importantes de cidadania e ao cumprimento das regras da escola. No entanto, alguns professores expressam a sua preocupação relativamente a certos aspectos que podem prejudicar a acção educativa da escola no sentido do desenvolvimento das competências de cidadania, como por exemplo, a questão das vivências a nível familiar.

Pareceu-nos, após a análise e tratamento das entrevistas, que foi pouco enfatizada pelos docentes a vertente da participação activa e ligação à vida da comunidade. Consideramos que existe a necessidade de estimular a aproximação entre a escola e o meio envolvente, pois, «a escola não pode ser apenas um edifício ou uma casa do saber. A escola define-se fundamentalmente pelas pessoas que nela trabalham, convivem, aprendem e ensinam e pela sua inserção e naturalização na comunidade local. A escola deve abrir-se à comunidade, desenvolvendo projectos educativos comuns e a comunidade deve gostar da sua escola. Não faz sentido que as escolas permaneçam como ithas isoladas no seio da sociedade sem uma abertura e uma adaptação permanente aos marcos socioculturais do meio em que estão inseridas» (Peres, 1999:126). No entanto, parece-nos que ao longo dos discursos expressos nas entrevistas não se revelou a existência de uma verdadeira cultura comunicativa entre a escola e a comunidade, ficando esta vertente pelo simples conhecimento do meio local. Defendemos que é importante a participação dos alunos na vida da comunidade, não só ao nível do conhecimento do meio local, mas também, ao nível da participação em campanhas de instituições 
locais, de realizações conjuntas e de apoio e colaboração regular com instituições da comunidade. A escola, ao valorizar a participação activa na comunidade, desempenha um papel fundamental relativamente à transmissão de conhecimentos acerca das instituições políticas e sociais e ao desenvolvimento de hábitos de participação nos grupos e instituições da comunidade.

A questão do envolvimento e participação do aluno no funcionamento e na vida da instituição escolar parece-nos uma outra vertente que deveria ser mais desenvolvida nas vivências escolares. No entanto, foram referidas, por alguns dos professores, a realização de assembleias de turma e de escola, o envolvimento do aluno na organização da sala de aula e a distribuição de responsabilidades e tarefas ao nível da turma.

Das opiniões recolhidas do grupo de alunos entrevistados predomina a ideia de que todos os alunos entrevistados afirmam que se sentem bem na escola e gostam de a frequentar. Grande parte dos alunos admite que mantém uma boa relação com o seu professor, com quem já estabeleceu relações de amizade, e que recebem a sua ajuda na realização dos trabalhos e na explicação daquilo que não compreendem. Para estes alunos, a palavra aprender relaciona-se com uma perspectiva de integração no nosso país, vontade de saber mais e ainda o desempenho de um trabalho futuro. Relativamente ao rendimento escolar dos alunos, de um modo geral, podemos considerar que existe sucesso escolar nos casos estudados.

A maioria dos alunos referem que falam muitas vezes ou algumas vezes sobre esses hábitos e costumes, principalmente sobre as actividades que lá realizavam, a explicação do significado de palavras da sua língua materna e a descrição das brincadeiras preferidas. Verificamos que existe uma partilha de brincadeiras entre os alunos entrevistados e os alunos portugueses e que os alunos estrangeiros têm uma boa relação com os seus colegas portugueses, brincando todos juntos.

Em relação às dificuldades sentidas no relacionamento com os colegas, a maior parte dos alunos revelam que nos primeiros dias sentiu alguma dificuldade em estabelecer contacto com os seus colegas. Alguns dos alunos oriundos de países de leste europeu indicam a língua estrangeira como a principal dificuldade para estabelecer as relações interpessoais.

De um modo geral, todos os alunos demonstram ter conhecimento dos seus direitos e deveres da vida em comum em meio escolar. As crianças revelaram igualmente ter conhecimento dos seus deveres na vida em sociedade, referindo deveres relativos à boa educação no relacionamento 
entre as pessoas, ao respeito pelos outros no convívio em sociedade, deveres relacionados com a preservação da natureza e do meio ambiente e outros ligados à prevenção rodoviária. É frequente conversarem e discutirem sobre problemas e acontecimentos da vida em sociedade através, principalmente, de notícias divulgadas pelos órgãos de comunicação social, acerca do meio local, nacional e até global. Os alunos salientam que são também tratados assuntos relacionados com problemas ambientais, sobretudo com a preservação da natureza, com a poluição e com a separação e tratamento dos lixos.

Das opiniões recolhidas do grupo de encarregadas de educação entrevistadas predomina a ideia que a maioria das nossas entrevistadas veio para o nosso país com o objectivo de encontrar um trabalho que permitisse melhorar o seu nível financeiro de modo a proporcionar uma vida melhor à sua família. Constatamos que actualmente, a família nuclear das entrevistadas (pais e filhos) se encontra em Portugal, tendo já ocorrido o reagrupamento familiar, com excepção de um caso em que a encarregada de educação vive apenas com a sua filha.

A questão da língua é apontada pelas inquiridas de países de leste da Europa como a principal dificuldade da sua integração no nosso país. Algumas das entrevistadas brasileiras revelaram que sentiram algum preconceito e discriminação, o que dificultou o seu processo de integração. Foi perceptível a ideia que a questão da integração das famílias imigrantes pode ser realizada de uma forma mais efectiva, a partir do momento em que começam a usufruir dos serviços de algumas instituições, neste caso a instituição escolar. Quanto às facilidades sentidas salientam as boas amizades estabelecidas em Portugal e a facilidade de relacionamento com outras pessoas. Parece-nos, através da análise das suas opiniões, que estas imigrantes se sentem bem no nosso país.

Em casa, os elementos do agregado familiar das encarregadas de educação de países do leste europeu falam a língua do seu país de origem, no entanto, duas das entrevistadas mostram-se preocupadas pela possibilidade de os seus filhos esquecerem a língua materna, pois algumas das crianças começam a exprimir-se com mais facilidade na língua portuguesa e a esquecer certas palavras (a nível oral e escrito) da língua materna.

Todas as entrevistadas revelam que gostam que os filhos frequentem a escola portuguesa, mostram interesse pelo processo educativo dos filhos e a maioria mantém um contacto regular com a professora do filho. Consideram que a relação dos filhos com os colegas e com a professora 
é boa, não apontando qualquer tipo de problema nesse relacionamento. A questão do conhecimento da língua portuguesa é considerada pelas imigrantes de leste como um factor facilitador do bom relacionamento entre as crianças estrangeiras e as portuguesas.

As encarregadas de educação pensam que os seus filhos recebem a necessária atenção e apoio por parte das suas professoras, comentando que estas proporcionam um ambiente acolhedor, fazendo com que as crianças estrangeiras se sintam bem na escola. Referem ainda que as professoras se preocupam e se esforçam por explicar quando o aluno estrangeiro não entende algo, comunicam com as entrevistadas sempre que consideram necessário, mostrando-se receptivas em relação às mensagens que vêm de casa. É ainda valorizado o interesse demonstrado pelas professoras em relação ao processo de ensino-aprendizagem das crianças.

Expondo a sua opinião sobre a integração dos seus filhos, as entrevistadas consideram que não existiu qualquer tipo de problemas na integração das crianças no meio escolar. Os seus filhos estabeleceram com facilidade relações de amizade com os seus colegas portugueses, existindo um bom relacionamento entre eles e com as respectivas professoras. A maioria das entrevistadas, quer brasileiras quer de países de leste, considera que as aulas de apoio na língua portuguesa poderiam contribuir para uma melhor integração das crianças estrangeiras. Uma das entrevistadas, originária de um país de leste, sugere que seria estimulante que este apoio fosse ministrado por um professor que dominasse as duas línguas, a portuguesa e a do país de origem, de modo a não permitir que as crianças esquecessem por completo a língua do país de origem, que faz parte da sua identidade cultural. Para além do apoio, são referidas outras medidas para uma melhor integração: prática de actividades escolares de valorização da cultura do país de origem, envolvendo todos os alunos da escola e a intervenção da assistência social.

As encarregadas de educação vindas de países do leste da Europa, quando confrontadas a avaliar o ensino oficial português do $1 .{ }^{\circ} \mathrm{CEB}$ comparativamente ao ensino oficial do país de origem, salientam que o ensino é mais exigente nos países de origem, mas elogiam a apresentação e a forma como estão elaborados os manuais do $1 .{ }^{\circ}$ CEB portugueses. As entrevistadas brasileiras acentuam a qualidade do ensino português, onde encontram mais disponibilidade, mais interesse pelo aluno, maior empenho em fazer compreender os conteúdos programáticos, maior exigência por parte dos docentes portugueses, o que contribui para o desenvolvimento das capacidades e do sentido de responsabilidade dos alunos. 
Terminamos estas reflexões e considerações finais com algumas ideias que, apesar de estarem subjacentes ao longo do trabalho, achamos importante aqui registar. A educação na sociedade actual direccionada para a cidadania, para a paz, para a educação intercultural, educação ambiental, não se pode reduzir apenas à transmissão de conhecimentos, a um cognitivismo mecanicista, indiferente a conteúdos éticos e valorativos. A educação não poderá cultivar os direitos do Homem, a paz e a democracia se não adoptar, de um modo crítico, os seus valores intrínsecos. Por outro lado, educar não é só fornecer conhecimentos, é dar ao aluno meios suficientes para a construção da sua autonomia e da sua identidade.

Ressaltamos que a educação para a cidadania compete a todas as instituições da sociedade, desde a família, a diversas organizações não governamentais ou governamentais, uma vez que a tarefa de despertar qualidades, consciências, liberdade, autonomia e responsabilidade está confiada, primeiramente, à família e à escola, mas também à vida social diária, dado que ser cidadão é assumir os deveres de solidariedade, de pertença e de respeito mútuo. No entanto, consideramos que a escola, enquanto instituição continua a ser um local privilegiado para esse efeito, pois tem responsabilidades acrescidas na promoção de valores de cidadania nas crianças e jovens das novas gerações, sendo necessária a sensibilização de todos os agentes envolvidos no processo educativo.

Face às transformações sócio-histórico-morais que têm vindo a ocorrer na sociedade, a escola tem, actualmente, como finalidade primordial a formação integral de pessoas enquanto sujeitos edificadores do seu próprio processo de identificação pessoal, numa actividade partilhada e de diálogo e é-lhe requerida, com um grau de exigência cada vez maior, mais responsabilidade a nível da educação para a cidadania. A escola educa e prepara cidadãos de hoje e para hoje, no entanto deve fazê-lo a pensar no futuro. Para além disso, a educação pode desempenhar um papel regenerador de certas práticas da sociedade, dado que ela admite, nas suas finalidades, uma perspectiva (re)criadora, o que faz com que aumente a responsabilidade da escola e haja necessidade urgente de empenho de todos os agentes educativos envolvidos. A escola, como local de convergência e acolhimento de diferentes culturas e de potenciais conflitos, deve promover uma educação intercultural que seja realmente um factor de coesão e de paz, socializando no plural e educando para um futuro melhor. Deve igualmente ambicionar conseguir desempenhar com sucesso a tarefa imprescindível da educação para a cidadania, sendo, para isso, necessária a sua mudança, no sentido de a tornar um local de procura incessante e afirmação de uma cidadania activa, exigente e responsável. 
A cidadania é uma aposta na responsabilidade. Cultivar a experiência cívica na escola é um dever básico de toda a comunidade educativa. Desde a construção da autonomia ao desenvolvimento de uma consciência atenta aos desafios da justiça, da solidariedade, da liberdade, da cooperação, da qualidade de vida, da responsabilidade, do respeito pelos outros e pela liberdade alheia, do civismo, da preservação do meio ambiente, todos somos chamados a movimentar esforços e energias no sentido da protecção da dignidade humana.

Na educação para a cidadania, é essencial considerar-se a criança e o jovem como pessoa e futuro cidadão, na sua globalidade de ser no mundo, bastante para além da sua condição de aluno e igualmente para além dos contornos da instituição escolar. A educação para a cidadania deve permitir não só vivências cognitivas, mas também vivências pessoais, afectivas e emocionais. Deve, igualmente, possibilitar um caminho de aprendizagem da aceitação da diferença e do respeito pelo outro, perspectivando o pluralismo como uma característica da sociedade actual, como algo de valioso e factor de enriquecimento para todos. A educação para a cidadania deve basear-se e apoiar-se em modelos e práticas educativas que fomentem a melhoria do comportamento do ser humano ao nível da justiça, respeito pela diferença, cooperação, solidariedade e de formas de convivência e comunicação, que valorize a autonomia intelectual e afectiva, o diálogo e o espírito de envolvimento e de participação na vida da comunidade. Através do conhecimento dos direitos do Homem, tarefa levada a cabo pela educação, a criança poderá tornar-se um verdadeiro cidadão, isto é, uma pessoa capaz de exigir o respeito dos seus direitos, mas também, o respeito dos direitos dos outros. Num mundo pluralista, de vários saberes e culturas, de várias pertenças, de incertezas e de complexidades, a educação para a cidadania converte-se em sinónimo de educação permanente, a partir da reflexão constante e das experiências de vida. A cidadania, mais do que um valor jurídico, torna-se um valor social e ético, com protecção legal e política. 


\section{REFERÊNCIAS BIBLIOGRÁFICAS}

ABDALLAH-PRECEILLE, M. (1986). Vers une Pedagogie Interculturelle. Paris: INRP.

ABRANTES, P. (2001). Reorganização Curricular do Ensino Básico: Princípios, Medidas e Implicações - Decreto-Lei: 6/2001. Lisboa: Ministério da Educação/Departamento da Educação Básica.

AMARAL, C. (2003). «Em torno do Conceito de Cidadania». In RIBEIRO, M. (coord.). Europa em Mutação. Coimbra: Quarteto Editora, pp. 289-310.

APAP, G. et al (2002). A Construção dos Saberes e da cidadania: Da escola à cidade. Porto Alegre: Artmed.

APPEL, M. e BEANE, J. (orgs.). (2000). Escolas Democráticas. Porto: Porto Editora.

BARBALET, J. M. (1989). A Cidadania. Lisboa: Editorial Estampa.

BARDIN, L. (1995). Análise de Conteúdo. Lisboa: Edições 70.

BOGDAN, R. e BIKLEN, S. (1997). Investigação Qualitativa em Educação - Uma introdução à teoria e aos métodos. Porto: Porto Editora.

CAMPOS, B. (1991). Educação e Desenvolvimento Pessoal e Social. Porto: Edições Afrontamento.

CANOTILHO, J. J. e MOREIRA, V. (orgs.). (1997). Constituição da República Portuguesa. Coimbra: Coimbra Editora.

CARLIER, J. - Y. (1998). «Vers une Citoyenneté Européenne Ouverte». Annales d' Études Européennes de l' Université Catholique de Louvain. Bruxelles, vol.2, pp.119-134.

CARD0SO, C. (1996). Educação Multicultural - Percursos para Práticas Reflexivas. Lisboa: Texto Editora.

CARDOSO, C. (coord.) (1998). Gestão Intercultural do Currículo 1. ${ }^{\circ}$ Ciclo. Lisboa: Secretariado Coordenador dos Programas de Educação Multicultural.

CARMO, H. e FERREIRA, M. M. (1998). Metodologia da Investigação: Guia para Auto-aprendizagem. Lisboa: Universidade Aberta. 
CARVALHO, A. D. (org.) (2001). Filosofia da Educação: Temas e Problemas. Porto: Edições Afrontamento.

CASTLES, S. (1994). «Democracy and Multicultural Citizenship. Australian Debates and their Relevance for Western Europe». In: BAUBOCK, R. (ed.). From Aliens to Citizens - Redefining the Status of Immigrantes in Europe. European Centre Vienna: Avebury.

CASTLES, S. (2000). «Underclass or Excludion: Docial Citizenship for the Ethnic Minorities». In Ellie Vasta (ed.). Citizenship, Community and Democracy. London: Macmillan Press, pp. 22-44.

CLANET, C. (1990). L'Interculturel - Introduction aux approaches interculturelles en education et sciences humaines. Toulouse: Presses Universitaire du Mirail.

CONSELHO NACIONAL DE EDUCAÇÃO (2000). Educação Intercultural e cidadania Europeia. Lisboa: Edição do CNE/ME.

CORTESÃO, L. e STOER, S. (1995). Projectos, Percursos, Sinergias no campo da Educação Intercultural - Relatório Final. Porto: Centro de Investigação e Intervenção Educativas da Faculdade de Psicologia e de Ciências da Educação da Universidade do Porto.

CORTESÃO, L. (coord.) (2000). Na Floresta dos Materiais: Catálogo analítico de materiais de formação para a diversidade. Oeiras: Celta Editora.

CRUZ, M. B. (1998). «Democracia e Cidadania: O Papel dos Valores». In Colóquio/Educação e Sociedade, n. ${ }^{\circ} 3$ (Nova Série). Lisboa: Fundação Calouste Gulbenkian , pp. 37-48.

DELORS, J. et al (1996). Educação, um Tesouro a Descobrir. Relatório para a UNESCO de Comissão Internacional sobre Educação para o Século XXI. Porto: Edições Asa.

DEPARTAMENTO DA EDUCAÇÃO BÁSICA (1998). Organização Curricular e Programas - Ensino Básico - 1. ${ }^{\circ}$ Ciclo. Mem Martins: Ministério da Educação (2. ${ }^{\mathrm{a}}$ edição).

DEPARTAMENTO DA EDUCAÇÃO BÁSICA (2000). Educação Intercultural: Potenciar a Diversidade - Entrelaçar Culturas. Lisboa: ME/DEB.

DEPARTAMENTO DA EDUCAC̦ÃO BÁSICA (2001). Currículo Nacional do Ensino Básico: Competências Essenciais. Lisboa: DEB/ME. 
ESTRELA, A. (1986). Teoria e Prática de Observação de Classes: Uma estratégia de formação de professores. Lisboa: Instituto Nacional de Investigação Científica (2. ${ }^{a}$ edição).

FERREIRA, M. (2003). Educação Intercultural. Lisboa: Universidade Aberta.

FIGUEIREDO, C. (2002). «Horizontes da Educação para a Cidadania na Educação Básica». In ABRANTES, P.; FIGUEIREDO, C.; SIMÃO A. Reorganização curricular do Ensino Básico: Novas Áreas Curriculares. Lisboa: Ministério da Educação/Departamento da Educação Básica.

FIGUEIREDO, I. (1999). Educar para a cidadania. Porto: Edições Asa.

FONSECA, A. M. (2000). Educar para a cidadania - Motivações, Princípios e Metodologias. Porto: Porto Editora.

FONSECA, A. M.(2002). Formação Cívica - Guia de Orientação para o Ensino Básico. Porto: Porto Editora.

FORMOSINHO, J. et al (1992). Formação Pessoal e Social. Porto: Sociedade Portuguesa de Ciências da Educação.

GHIGLIONE, R. e MATALON, B. (1993). O Inquérito - Teoria e prática. Oeiras: Celta Editora.

GIDDENS, A. e TURNER, J. (1990). «Introduccion». In GIDDENS, A. e TURNER, J. La Teoria Social Hoy. Madrid: Allianza Universidad, pp.9-21.

GOODSON, I. (1995). «Dar voz ao Professor: As histórias de vida dos professores e o seu desenvolvimento profissional». In NÓVOA, A. (org.). Vidas de Professores. Porto: Porto Editora, pp.63-78 (2. ${ }^{a}$ edição).

HARGREAVES, A. (1998). Os Professores em Tempos de Mudanca - O trabalho e a cultura dos professores na idade pós-moderna. Alfragide: Editora McGraw-Hill de Portugal, Lda.

HENRIQUES, M. et al (1999). Educação para a cidadania. Lisboa: Plátano Editora.

HORTA, A. (org.). (2003). Cidadania e Participação Política. Seminário do Mestrado em Relações Interculturais. Porto: Universidade Aberta. 
INSTITUTO NACIONAL DE ESTATÍSTICA (2001). Estatísticas Demográficas. Extractos de emigração e imigração em Portugal. Lisboa: INE.

JACKSON, J. A. (1991). «A Migração como Processo Social». In Migrações. Lisboa: Ed. Escher, pp.1-22.

KYMLICKA, W. (1995). Multicultural Citizenship. Oxford: Oxford University Press.

LEITÃO, J. (1999). Os Imigrantes e a Integração no Caso Português: Algumas considerações. Alto-comissário para a Imigração e Minorias Étnicas. Porto: Universidade Aberta.

LEITE, C. (1996). «O Multiculturalismo na Educação Escolar: que estratégias numa mudança curricular?». In Inovação, Vol. 9, n. ${ }^{0} 1$ e 2, pp. 63-81.

LEITE, C. (2002). O Currículo e o Multiculturalismo no Sistema Educativo Português. Lisboa: Fundação Calouste Gulbenkian - Fundação para a ciência e a Tecnologia.

LEITE, C. e TERRASÊCA, M. (1995). Ser Professorla num Contexto de Reforma. Porto: Edições Asa.

LEITE, C. e RODRIGUES, M. L. (2001). Jogos e Contos numa Educação para a Cidadania. Lisboa: Instituto de Inovação Educacional.

MACHADO, F. (1996). «Minorias e Literacia: imigrantes guineenses em Portugal». In BENAVENTE, A. (coord.). A Literacia em Portugal. Lisboa: Conselho Nacional de Educação, pp.171-238.

MACHADO, F. (1997). "Contornos e especificidades da Imigração em Portugal». In Sociologia - Problemas e Práticas, n. ${ }^{0} 24$, pp.9-44.

MARCONI, M. e LAKATOS, E. (1990). Técnicas de Pesquisa. São Paulo: Edições Atlas.

MARQUES, R. (1992). «A Educação Sócio-moral - Uma análise curricular do ensino básico em Portugal». In FORMOSINHO, J. et al. Formação Pessoal e Social. Porto: Sociedade Portuguesa de Ciências de Educação, pp. 77-98.

MARQUES, R. (2002). Valores Éticos e Cidadania na Escola. Barcarena: Editorial Presença. 
MENEZES, I.; XAVIER, E.; CIBELE, C. (1997). Educação Cívica em Portugal nos Programas e Manuais do Ensino Básico. Lisboa: Instituto de Inovação Educacional.

MINISTÉRIO DA EDUCAÇÃO. (1992). Roteiro da Reforma do Sistema Educativo - Guia para os pais e professores, 1986-1996. Lisboa: ME.

MINISTÉRIO DA EDUCAÇÃO. (1998). Educação, Integração, Cidadania Documento orientador das políticas para o Ensino Básico. Lisboa: ME.

NETO, F. (2002). Psicologia Intercultural. Lisboa: Universidade Aberta.

NOGUEIRA, C. e SILVA, I. (2001). Cidadania - Construção de novas práticas em contexto educativo. Porto: Edições Asa.

O' LEARY, S. (1996). The Evolving Concept of Community Citizenship - From the free movement of persons to union citizenship. European Monographs, 13, Kluwer.

OUELLET, F. (1991). L'Education Interculturelle - Essai sur le contenu de la formation des maîtres. Paris: Édition L' Harmattan.

OUELLET, F. (2002). Les défis du pluralisme en éducation. Les Presses de l'Université Laval.

PATRÍCIO, M. (1993). Lições de Axiologia Educacional. Lisboa: Universidade Aberta, pp.219-281.

PERES, A. (1999). Educação intercultural: Utopia ou Realidade? Porto: Profedições, Lda/Jornal a Página.

PERISTA, H. e PIMENTA, M: (1993). «Trajectórias Profissionais e Inserção Laboral dos Imigrantes Residentes em Bairros Degradados de Lisboa». In SILVA, M B. et al (org.). Emigração/Imigração em Portugal. Lisboa: Fragmentos, pp.434-445.

PERRENOUD, P. (2000). Dez Novas Competências para Ensinar. Porto Alegre: Editora Artned.

PERRENOUD, P. (2001). Porquê Construir Competências a partir da Escola? Porto: Edições Asa.

PRAIA, M. (1999). Educação para a cidadania: Teoria e Práticas. Porto: Asa Editores. 
QUIVY, R. e CAMPENHOUDT, L. V. (1998). Manual de Investigação em Ciências Sociais. Lisboa: Gradiva (2. ${ }^{a}$ edição).

RAMOS, M. C. (1995). «Desafios da Mobilidade Internacional do Trabalho em Portugal». In ALVES, M. B. et al (org.) Por onde vai a Economia Portuguesa? Lisboa: Instituto Superior de Economia e Gestão, pp.129-176.

RAMOS, M. C. (1996). «Migrações Internacionais e Novos Desafios»Extracto de «Economia do Trabalho, Sócio-economia e Migrações Internacionais». In FERREIRA, J. M. et al (org.) Entre a Economia e a Sociologia. Oeiras: Celta Editora, pp.254-264.

RAMOS, M. C. (1999). «Integrar as migrações na União». In Economia Pura. Ano II, n. ${ }^{0} .14$, Julho, pp.96-98.

RAMOS, M. C. (org.). (2002/2003). Grandes Diásporas. Seminário do Mestrado em Relações Interculturais. Porto: Universidade Aberta.

RAMOS, M. C. (2003a). Acção Social na Área do Emprego e da Formação Profissional. Lisboa: Universidade Aberta.

RAMOS, M. C. (2003b). «Le Portugal, pays relais des migrations internacionales». In Migrations-Etudes, n. ${ }^{\circ}$ 116, Agosto-Setembro. Paris: DPM, ADRI, $16 \mathrm{p}$.

RAMOS, M. C. (2003c). «Dinâmicas e Estratégias Socioeconómicas relativas à Emigração portuguesa: alguns vectores e propostas de reflexão/intervenção». In ALVES, J. et al. Porto de Partida - Porto de Chegada: a emigração portuguesa. Lisboa: Âncora Editora, pp. 57-76.

RAMOS, M. C. (2004). «Nouvelles dynamiques migratoires au Portugal et processus d'intégration». In Reveu Française des Affaires Sociales, n. ${ }^{\circ}$ 2, Avril-Juin. Paris: Ministère de l'Emploi et de la Solidarité, pp. 111-114.

RAMOS, M. C. (2005). «Le Portugal, de l'Emigration à l'Immigration». In Revue Santé, Société et Solidarité «Immigration et Intégration», n. ${ }^{0} 1$. Québec, pp. 203-215.

RAMOS, M. C. (2007). «Diásporas, culturas e coesão social» In BIZARRO, R. (coord.). Eu e o outro. Estudos multidisciplinares sobre identidade(s), diversidade(s) e práticas interculturais. Porto: Areal Editores, pp. 78-95. 
RAMOS, N. (2001). «Comunicação, Cultura e Interculturalidade: Para uma comunicação intercultural». In Revista Portuguesa de Pedagogia, (35,2), pp.155-178.

RAMOS, N. (org.). (2003). Comunicação intercultural. Seminário do Mestrado em Relações Interculturais. Porto: Universidade Aberta.

RAMOS, N. (2004). Psicologia Clínica e da Saúde. Lisboa: Universidade Aberta.

RAMOS, N. (2007). «Interculturalidade, educação e desenvolvimento - o caso das crianças migrantes». In BIZARRO, R. (coord.). Eu e o outro. Estudos multidisciplinares sobre identidade(s), diversidade(s) e práticas interculturais. Porto: Areal Editores, pp. 367-375.

RIBEIRO, A. C. (1992). «Currículo: natureza e âmbito». In Guia da reforma Curricular. Lisboa: Texto Editora, pp. 75-94.

ROCHA-TRINDADE, B. (1995). Sociologia das Migrações. Lisboa: Universidade Aberta.

ROSA, A. (2002). «Multiculturalidade e Educação». In SOS Racismo-A Imigração em Portugal. Lisboa: SOS Racismo, pp.353-365.

ROLDÃO, M. C. (1999). «Cidadania e Currículo». In Inovação, vol. 12, n. ${ }^{0} 1$, pp.9-26.

SACRISTÁN, J. G. (2003). Educar e conviver na cultura global. Porto: Edições Asa.

SANTOS, B. S. (1994). Pela mão de Alice - O Social e o Político na Pós-modernidade. Porto: Edições Afrontamento.

SERRÃO, J. (1985). «Notas sobre a Emigração e a Mudança Social no Portugal Contemporâneo». In Análise Social, Vol. XXI, n. ${ }^{\circ}$.87-88-89, pp. 995-1004.

SILVA A. S. (2000). «Conclusões da Conferência». In Educação, Sociedade e cidadania - Conferência Internacional - Actas - Lisboa, 17-19 de Maio de 1999. Lisboa: ME/GAERI.

SILVA, A. e FIGUEIREDO, C. (1999). «A Educação para a Cidadania no Ensino Básico e Secundário Português (1974-1999)». In Inovação, 12 (1), pp.27-45. 
SOUTA, L. (1997). Multiculturalidade e Educação. Porto: Profedições.

STOER, S. e CORTESÃO, L. (1999). Levantando a Pedra - Da Pedagogia Inter/Multucultural às Politicas Educativas numa Época de Transnacionalização. Porto: Edições Afrontamento.

TAYLOR, C. (1994). «A Politica de Reconhecimento». In TAYLOR, C. (eds.) Multiculturalismo: Examinando a Política de Reconhecimento. Lisboa: Instituto Piaget, pp.45-94.

TORRES, C. A: (2001). «Educação, Democracia - Tensões e Dilemas no Mundo Contemporâneo». In TEODORO, A. (org.) Educar, Promover e Emancipar - Os contributos de Paulo Freire e Rui Grácio para uma pedagogia emancipatória. Lisboa: Edições Universitárias Lusófonas, pp.17-39.

VALA, J. (1986). «A Análise de Conteúdo». In SILVA, A. S. e PINTO, J. M. (orgs.) Metodologia das Ciências Sociais. Porto: Edições Afrontamento, pp.101-128.

VIEIRA, R. (1995). «Mentalidades, Escola e Pedagogia Intercultural». In Educação, Sociedade e Culturas, n. ${ }^{\circ} 4$, pp.127-147.

\section{Sites Consultados}

Ministério da Educação:

“htttp://www.dapp.min-edu.pt/estat/99_00/índice_z.html”

Ministério da Administração Interna:

"http//www.mai.gov.pt/data/001/005/pdf/porsexo_03.pdf"

\section{Legislação consultada}

Constituição da República, 1997.

Lei n. ${ }^{\circ}$. 46/86, de 4 de Outubro, alterada pela Lei n. ${ }^{\circ}$ 115/97, de 19 de Setembro - Lei de Bases do Sistema Educativo.

Decreto-Lei n. ${ }^{0}$ 286/89, de 29 de Agosto - Reforma dos Currículos dos Ensinos Básico e Secundário.

Decreto-Lei n. ${ }^{0}$ 6/2001, de 18 de Janeiro - Princípios orientadores da organização, gestão e desenvolvimento do currículo do ensino básico. 
Decreto-Lei n. ${ }^{\circ}$ 209/2002, de 17 de Outubro - Altera o artigo $13 .^{\circ}$ e anexos I, II e III do Decreto-Lei n. ${ }^{\circ}$ 6/2001, de 18 de Janeiro.

Despacho Normativo n. ${ }^{9}$ 98-A/92, de 20 de Junho - Avaliação das aprendizagens no ensino básico.

Despacho Normativo n. ${ }^{0}$ 644-A/94, de 13 de Setembro - Avaliação das aprendizagens no ensino básico.

Despacho Normativo n. ${ }^{\circ}$ 30/2001, de 19 de Julho - Determinação das orientações e disposições relativas à avaliação consagradas no Decreto-Lei n. ${ }^{\circ}$ 6/2001, de 18 de Janeiro. Substitui o Despacho Normativo n. ${ }^{\circ}$ 98-A/92, de 20 de Junho, e demais legislação subsequente sobre a mesma matéria.

Despacho Normativo n. ${ }^{0}$ 1/2005, de 5 de Janeiro - Princípios e os procedimentos da avaliação das aprendizagens e competências dos alunos dos três ciclos do ensino básico. Substitui o Despacho Normativo n. ${ }^{\circ}$ 30/2001, de 19 de Julho.

Despacho Normativo n. ${ }^{0}$ 50/2005, de 20 de Outubro - Orientações e disposições relativas à avaliação consagradas no Decreto-Lei n. ${ }^{\circ}$ 6/2001, de 18 de Janeiro. Princípios de actuação e normas orientadoras para a implementação de estratégias de intervenção com vista ao sucesso dos alunos. 


EDIÇÃO CO-FINANCIADA PELO FUNDO SOCIAL EUROPEU

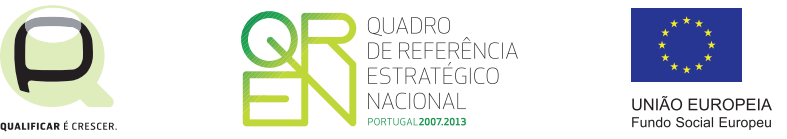

